\title{
Zorgen voor een draaglijk bestaan : morele ervaringen van verpleegkundigen
}

Citation for published version (APA):

Smits, M. J. E. H. (2004). Zorgen voor een draaglijk bestaan : morele ervaringen van verpleegkundigen. [Doctoral Thesis, Maastricht University]. Aksant. https://doi.org/10.26481/dis.20040213mjs

Document status and date:

Published: 01/01/2004

DOI:

10.26481/dis.20040213mjs

Document Version:

Publisher's PDF, also known as Version of record

\section{Please check the document version of this publication:}

- A submitted manuscript is the version of the article upon submission and before peer-review. There can be important differences between the submitted version and the official published version of record.

People interested in the research are advised to contact the author for the final version of the publication, or visit the DOI to the publisher's website.

- The final author version and the galley proof are versions of the publication after peer review.

- The final published version features the final layout of the paper including the volume, issue and page numbers.

Link to publication

\footnotetext{
General rights rights.

- You may freely distribute the URL identifying the publication in the public portal. please follow below link for the End User Agreement:

www.umlib.nl/taverne-license

Take down policy

If you believe that this document breaches copyright please contact us at:

repository@maastrichtuniversity.nl

providing details and we will investigate your claim.
}

Copyright and moral rights for the publications made accessible in the public portal are retained by the authors and/or other copyright owners and it is a condition of accessing publications that users recognise and abide by the legal requirements associated with these

- Users may download and print one copy of any publication from the public portal for the purpose of private study or research.

- You may not further distribute the material or use it for any profit-making activity or commercial gain

If the publication is distributed under the terms of Article $25 \mathrm{fa}$ of the Dutch Copyright Act, indicated by the "Taverne" license above, 
ZORGEN VOOR EEN DRAAGLIJK BESTAAN 



\section{ZORGEN VOOR EEN DRAAGLIJK BESTAAN}

MORELE ERVARINGEN VAN VERPLEEGKUNDIGEN

\section{Proefschrift}

TER VERKRIJGING VAN DE GRAAD VAN DOCTOR AAN

DE UNIVERSITEIT MAASTRICHT

op gezag van de Rector Magnificus, Prof. Mr. G.P.M.F. Mols Volgens Het besluit VAN Het College VAN DECANEN,

IN HET OPENBAAR TE VERDEDIGEN

OP VRIJDAG 13 FEBRUARI 2004 OM 16.00 UUR

DOOR:

Marie-josée Elisa Hendrika SMits

GEBOREN OP 4 NOVEMBER 1964

TE HEERLEN (LIMBURC) 


\section{Promotores:}

Prof. Dr. G.A.M. Widdershoven

Prof. Dr. R. Vos

Co-promotor:

Dr. A.M. Meershoek

Beoordelingscommissie:

Prof. Dr. R. Ter Meulen (voorzitter)

Dr. I. Gremmen

Prof. Dr. M. Grypdonck (Universiteit Utrecht)

Dr. R. Houtepen

Prof. Dr. J. Tronto (Hunter College New York) 


\section{INHOUD}

DANKWOORD vi

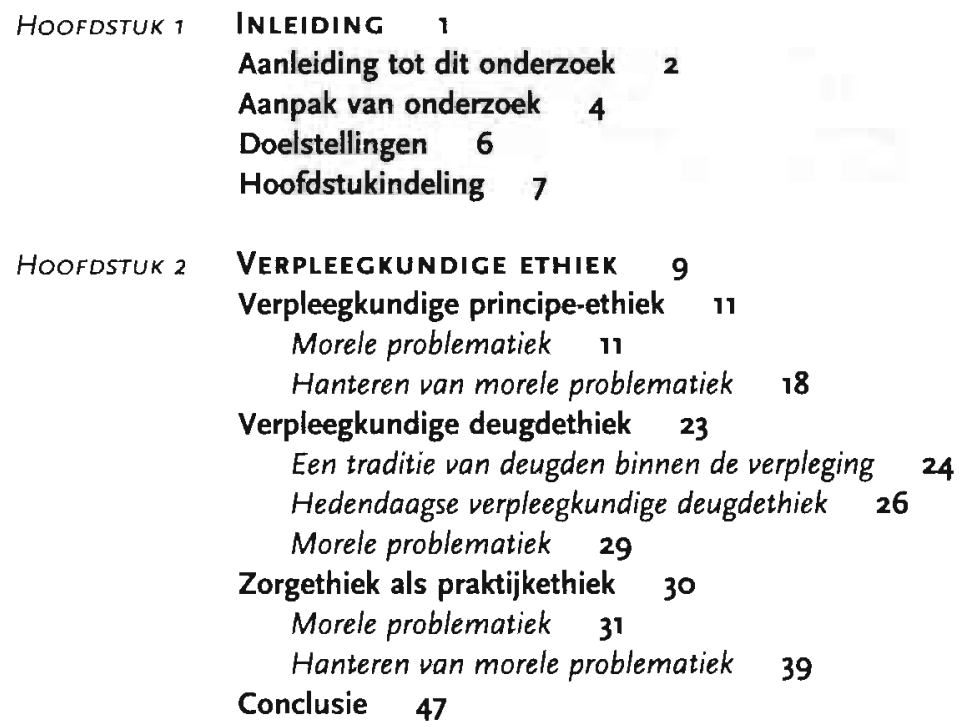

HOOFDSTUK 3 KWALITATIEF ONDERZOEK: OPZET EN AANPAK 49 Theoretisch kader en vraagstellingen $\quad 49$ Hematologie oncologie verpleging $\quad 52$ Dataverzameling, -analyse en verslaglegging 53 Conclusie 60

\section{HOOFDSTUK 4 DRAaGLIJKER MAKEN VAN HET BestaAN 6}

Behandeling van een ziek lichaam $\quad 62$ Ingrijpende behandelingen en onderzoeken $\quad 62$ Fysieke pijn en lijden $\mathbf{6}_{3}$ Overrompeld door de behandeling 71

Opgenomen zijn op een ziekenhuis afdeling Niet thuis maar in het ziekenhuis 77 Een ander leven $\quad 78$ Verloren zeggenschap over de eigen situatie $\quad \mathbf{8}_{3}$

Een levensbedreigende ziekte $\quad 85$ Eindigheid van het leven $\quad 85$ Samen 'ziek' 92

Conclusie 95 


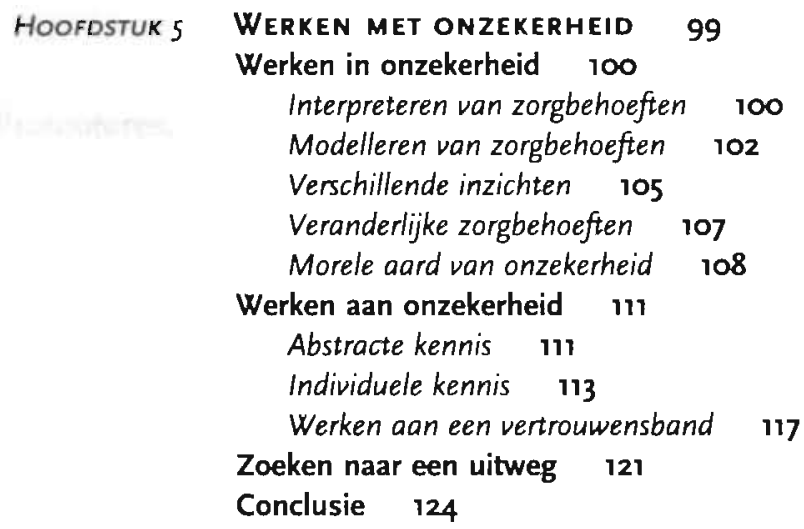

Hoofdstuk 6 Hanteren VAN SPANNINGEN 127

Meningsverschillen met patiënten 127

Zoeken naar overeenstemming $\quad 128$

Conflicten hanteren 133

Gaat het om nu of om later? 137

Zorgverlening in relatie tot behandelbeleid 138

Behandelbeleid belemmert goede zorg 139

Ruimte creëren 145

Conflicten hanteren 149

Zorg voor jezelf 152

Betrokkenheid is begrensd $\mathbf{1 5 2}$

Zoeken naar een evenwicht 154

Context van de afdeling 156

Zorg voor meerdere mensen 156

Professionele of goede zorg? 161

Onvoldoende ruimte voor reflectie 163

Conclusie 168

Hoofostuk 7 MORELE ERVARINGEN EN VERPLEEGKUNDIGE ETHIEK

171

De morele lading van dagelijkse zorg $\quad 174$

De morele lading van opvattingen van goede zorg en

zorgactiviteiten $\mathbf{1 7 4}$

De morele lading van zorg binnen de verpleegkundig ethiek 178

Zorgrationaliteit $\quad \mathbf{1 8 2}$

Zorgen is doen, kennen, voelen, redeneren en overleggen 183

Zorgrationaliteit binnen de verpleegkundige ethiek 185

Betrokkenheid 188

Verschillende betekenissen van betrokkenheid 188

Betrokkenheid binnen de verpleegkundige ethiek 191

In discussie met patiënten over de inhoud van zorg 196

Zoeken naar een gezamenlijk gedragen zorgproces 197 
Omgaan met meningsverschillen binnen de verpleegkundige ethiek 201

Macht en onmacht 206

Krijgen en nemen van ruimte 206

Macht en onmacht binnen de verpleegkundige ethiek $\quad 209$

Conclusie 211

HoOfdSTUK 8 EpILOOG 217

Reflectie op het onderzoek 218

De zorgethiek als theoretisch kader 218

Reikwijdte van de bevindingen $\mathbf{2 2 0}$

Ontwikkelingen binnen de verpleegkunde

Professionalisering $\mathbf{2 2 4}$

Inzicht in opvattingen van goede zorg 227

Beleid en zorg $\quad \mathbf{2 2 8}$

NOTEN 231

LiteratuUR 241

BIJLACEN 253

SAMENVATtINC 263

SUMMARY 271

Curriculum Vitae 277 


\section{DAN KWOORD}

$\mathrm{Na}$ tien jaar noeste arbeid is dit proefschrift eindelijk klaar. Ik ben tevreden met het resultaat. Mijn boodschap staat er in. Dat de lezer hem er uit moge halen. Tien jaar is geen geringe tijd om een proefschrift over goede zorg in de verpleging te schrijven. Zonder de zorg van velen, was dat ook niet gelukt. Ik wil een aantal mensen daarvoor bedanken.

Op de eerste plaats dank aan de verpleegkundigen van afdeling ro. Omdat ik met hen mee heb mogen lopen en vragen heb mogen stellen, heeft dit boek inhoud gekregen. Op de tweede plaats dank aan mijn promotieteam. Prof. Dr. Widdershoven, Guy: dank voor de kans die je me hebt gegeven om aan dit project te beginnen, de ondersteuning tijdens het proces en de ruimte om mijn eigen weg te gaan toen dat nodig was. Prof. Dr. Vos, Rein: dank voor de tijd en energie die je in mijn project hebt gestoken, terwijl het je structureel aan beiden ontbrak. Van jou heb ik geleerd om uit een brei van ideeën en teksten een proefschrift met een kop en een staart te destilleren. Dr. Meershoek, lieve Agnes: mijn steun en toeverlaat. Heel erg bedankt dat je jouw analytische inzicht, je emotionele steun en je organisatietalent voor mij hebt ingezet.

Mijn toenmalige collega's van de sectie Gezondheidsethiek en Wijsbegeerte en van het Instituut Gezondheidsethiek wil ik bedanken voor de inspirerende en intellectuele omgeving, waarin ook nog vaak ruimte was voor een persoonlijk gesprek. Een aantal van hen wil ik bij naam noemen. Rob Houtepen: voor de leerzame gesprekken over mijn proefschrift, je vermogen om mij te laten lachen over de gekke dingen des levens en de gezellige etenties bij jou thuis samen met Coleta en de meisjes. Anja Krumeich: dat je me hebt laten delen in je uitgebreide kennis van kwalitatief onderzoek en je relaxte opvattingen over het moederschap. Hellen Heutz: omdat je áltijd voor mij klaarstond, voor hulp en een praatje. Ingrid Lathouwer: voor je gemopper, je vertrouwen en de bereidheid ondersteuning te bieden als dat echt nodig was; Arnold van Alphen: voor het oplossen van kleine en grote computerproblemen, die écht niet allemaal alleen aan mij lagen! Ireen Proot: voor het prettige en persoonlijke contact tijdens en na het palliatieve zorgproject. Irma van der Ploeg: voor de gezellige saunabezoeken en onze gesprekken over grootse veranderingen in het leven. Louk Hollands: voor je warme aandacht en betrokkenheid. 
Met mijn kamergenoten heb ik bij de vakgroep altijd geboft. Marianne Potting: met jou kon ik heerlijk napraten over onze wederzijdse weekendescapades, met jou kon ik lief en leed delen en op jou kon ik terugvallen wanneer ik dat ene artikel niet kon vinden of als dat word-balkje weer eens op onverklaarbare wijze-was verdwenen. Lieve Ruth Beschop: met jou kon ik zalig lachen, je kon me troosten in je armen en je liet mij van je wijsheid profiteren. Ik hoop jullie nog lang als vriendinnen te behouden. Regien Heijmans was een waardig opvolger. We hebben nog even van elkaars gezelschap kunnen genieten voor ik bij de vakgroep vertrok.

Met een aantal mensen heb ik samen gestudeerd, ben ik samen aio geweest, werden we collega's en raakten we bevriend. In al die hoedanigheden heb ik hun inhoudelijke en persoonlijke ondersteuning mogen ervaren: Marc Berg, Roland Bal, Ruud Hendriks, Marleen Goumans en Michiel van Dorp. En niet te vergeten: Jessica Mesman, Antoinette de Bont en Saskia van der Lycke, die ook buiten de aio-soep bereid waren om steeds weer opnieuw mijn teksten te lezen en vol enthousiasme van commentaar te voorzien. Ik ben de laatste van ons groepje. Het is ook mij nu gelukt orn te promoveren! Mijn feestje wordt een beetje van ons allemaal! En ook voor alle andere (ex) promovendi, waarmee ik in de afgelopen jaren soep gegeten heb, hoofdstukken en artikelen heb besproken en over begeleiders heb geroddeld. Ik wil er een aantal noemen: Loes Kater, Nel Knols, Hannerieke van der Boom, Nienke Wilbrink, Minke Goldsteen, Rob van Hoorn.

Het werken aan dit proefschrift heeft een behoorlijke impact op mijn persoonlijke leven gehad. Er was altijd minder tijd en aandacht voor vrienden dan ik zou willen. Gelukkig hebben ze me niet in de steek gelaten en kan ik nog steeds van hun gezelschap genieten: Gerda, Marc, Margo, Jos, Suze, Thea en mijn lieve Ilse. Ik had ook vaker met Norbert of Tyroon een biertje willen drinken, met Wim naar de film willen gaan, met Peter (mijn allerbeste schoonbroer) een ritje in de Ferrari willen maken, met Pascalle willen afspreken of bij Bart en Ingrid in Bingelrade op bezoek gaan. Wie weet. Speciale dank aan mijn Ravelein-vriendinnen voor de praktische en emotionele ondersteuning, vooral bij het alleenstaand moederschap: Angel, Claire, Marleen, Sonja en last but not least mijn allerliefste buurviendin Monique.

Wie mijn paranimfen zouden worden stond all vast voordat ik aan dit proefschrift begon. Zij wisten blijkbaar beter waar ik zou eindigen dan ik zelf: Grete Visser: wat zal ik zeggen, samen met jou is mijn leven echt heel veel fij. ner. Lilian Smits: mijn lieve grote zus, een leven zonder jou is gewoonweg ondenkbaar.

Mijn ouders hebben ieder geheel op hun eigen manier voor mij gezorgd. Ze hebben altijd voor mij klaargestaan. Ze zijn erop blijven vertrouwen, dat er ooit een proefschrift zou komen. Ik hoop dat jullie trots op mij zijn. 
Mijn lieve Pieter. Nu negen jaar oud. Net iets jonger dan dit proefschrifttraject. Ik heb veel over zorg geleerd door voor jou te moederen. Het was en is fijn om voor jou te mogen zorgen. Ik heb je heel erg lief.

$\mathrm{Nu}$ kan ik dit decennium afsluiten en een nieuw begin maken. Ik wil Mariëtte Keijser bedanken dat ze als directeur van de regio Heerlen Zuid van VZR, mij de kans heeft gegeven om de overstap te maken naar de praktijk. Met veel plezier vervul ik de functie van Beleidsmedewerker in de ouderenzorg. En nu is er ook nog Pim. Nog maar net in mijn leven, maar het begint er al aardig op te lijken dat het prettig is om dit met jou te delen. 


\section{INLEIDING}

Tegenwoordig staat bij overheid en zorginstellingen de vraag hoog op de agenda, hoe voldoende mensen behouden kunnen worden voor het beroep van verplegende en verzorgende. Op maatschappelijk en politiek niveau wordt personeelsgebrek binnen de gezondheidszorg als groot probleem gezien. Vooral de voorspelde tekorten aan verplegend en verzorgend personeel baren ernstige zorgen.' Het Ministerie van VwS verwacht in 2004 een tekort van 44.000 mensen.

Een dergelijk probleem heeft ogenschijnlijk niets van doen met morele kwesties. Wanneer op maatschappelijk niveau gesproken wordt over ethiek in de gezondheidszorg, dan gaat het meestal over euthanasie, hulp bij zelfdoding, gendiagnostiek, rechtvaardige verdeling van middelen, en dergelijke. Er is nauwelijks aandacht voor kwesties die samenhangen met de dagelijkse zorg die verplegenden en verzorgenden aan zorgvragers geven. In dit proefschrift wordt ervan uit gegaan dat het zinvol is aandacht te besteden aan morele kwesties die verbonden zijn met de dagelijkse zorgverlening, als het gaat om de vraag hoe voldoende mensen voor het vak behouden kunnen worden. Dagelijkse morele kwesties als de volgende. Welke zorg is wenselijk voor patiënten die fysiek of emotioneel lijden? Hoe kan de eigenheid van zorgvragers gerespecteerd worden? Wanneer is betrokkenheid bij zorgvragers wenselijk en waar liggen de grenzen daarvan? Hoe kan - binnen de context van een afdeling of instelling - ruimte gecreëerd worden voor wensen, vragen of behoeften van zorgvragers?

In dit boek wordt ingegaan op de vraag welke morele kwesties verplegenden en verzorgenden dagelijks op de werkvloer tegenkomen. In dit eerste hoofdstuk wordt de aanleiding en aanpak van onderzoek verder uitgewerkt in: vraagstellingen, theoretisch kader en methoden van dataverzameling. Bovendien worden de doelstellingen van het onderzoek uiteen gezet en wordt een overzicht gegeven van de hoofdstukindeling. 


\section{AANLEIDING TOT DIT ONDERZOEK}

Verplegenden en verzorgenden dragen zorg voor mensen die, om de één of andere reden niet in staat zijn om voor zichzelf te zorgen. Door de groei van de bevolking en allerlei medisch-technische ontwikkelingen is de vraag naar zorg de afgelopen jaren sterk toegenomen en groeit alleen nog maar als gevolg van een toename van chronisch zieken en de dubbele vergrijzing. 'Verplegenden en verzorgenden zijn in de zorgsector kwantitatief in de meerderheid.

De groeiende behoefte aan zorg gaat tegelijkertijd gepaard met een afname aan interesse voor het beroep van verplegende of verzorgende. Het blijkt niet eenvoudig om mensen te vinden, die op professionele basis zorg voor anderen op zich willen nemen. Eén van de initiatieven die de overheid daarom neemt is het verbeteren van het imago van het beroep. Begin 2000 startte een landelijke beeldvormingcampagne met als doel de instroom in verplegende en verzorgende beroepen te vergroten. Daarnaast tracht de overheid door het verbeteren van opleidingsmogelijkheden, het ontwikkelen van nieuwe beroepsperspectieven, verbeteren van secondaire arbeidsvoorwaarden en een hogere financiële beloning nieuwe mensen binnen te halen. Zorginstellingen lokken potentiële werknemers door het bieden van een geldelijke beloning, een vakantie reisje, een computer, extra premies of verbeterde arbeidsvoorwaarden.

Het beleid van overheid en zorginstellingen is er niet alleen op gericht nieuwe mensen te werven, maar heeft ook tot doel degenen die reeds als verplegenden en verzorgenden werkzaam zijn, voor het vak te behouden. Want het aantal van hen dat de gezondheidszorg de rug toekeert is groot. In 1999 deed dat $14 \%$, terwijl het percentage voor de algemene beroepsbevolking ligt op ro\%. Redenen die worden genoemd zijn: gebrek aan loopbaanperspectieven, de onmogelijkheid minder te gaan werken, slechte arbeidsomstandigheden zoals lichamelijke en geestelijke overbelasting en een werkklimaat dat door verplegenden en verzorgenden niet als ondersteunend wordt ervaren. ${ }^{4}$ $\mathrm{Bij}$ de helft had het vertrek naar eigen mening voorkomen kunnen worden, bijvoorbeeld als er meer aandacht was geweest voor werkdruk en ontplooiingsmogelijkheden.

Een belangrijke reden voor de uitval onder verplegenden en verzorgenden is stress en burn-out. Deze wordt onder andere veroorzaakt door frustraties en vermoeidheid, omdat er een te groot fysiek en/of emotioneel beroep op hen wordt gedaan door zorgvragers. Deze frustratie wordt nog verder versterkt wanneer de werkdruk hoog is. De spreuk 'The show must go on' is volgens Koopman (200I) ook op de verpleging van toepassing. "Immers, de patiënten kunnen hun behoefte aan verpleging nauwelijks uitstellen en zijn daarmee 
aangewezen op continuiteit van de zorgverlening. Verpleegkundigen ervaren dit gegeven als een vanzelfsprekendheid, die echter bij onvoldoende vacature invulling tot een ondraaglijke last kan uitgroeien" (Koopman 200r: 16). Andere redenen voor stress en burn-out die worden genoemd zijn onduidelijkheid over taken en verantwoordelijkheden en gebrek aan ruinte voor autonoom handelen. Verplegenden en verzorgenden bekleden een bijzondere positie in de gezondheidszorg. Niet alleen de organisatie waarin ze werken stelt bepaalde eisen aan hen, maar zij voeren ook opdrachten uit van artsen die de eindverantwoordelijkheid voor de behandeling dragen. Bovendien hebben zij een eigen taak en verantwoordelijkheid ten aanzien van de zorg voor zorgvragers. Deze middenpositie kan leiden tot tegenstrijdige of onduidelijke verdeling van taken en verantwoordelijkheden, waarvan frustraties en onvrede het gevolg kunnen zijn. Ook kan gebrek aan waardering of sociale ondersteuning van de directe leidinggevenden of van collegae leiden tot burnout klachten. ${ }^{6}$ Vooral wanneer verplegenden en verzorgenden zorgen voor zorgvragers die een sterk emotioneel beroep op hen doen, is een ondersteunend klimaat van leidinggevenden en collegae van belang om stress en burn-out te voorkomen.

Tegenwoordig speelt in het denken over de uitval onder verplegenden en verzorgenden een betrekkelijk nieuw argument een rol. Door sommigen? wordt naar voren gebracht dat het denkbaar is dat zij het vak verlaten uit frustratie als gevolg van gebrek aan ruimte voor hún opvattingen van goede zorg, binnen de cultuur van de gezondheidszorg waarin zij werkzaam zijn. "In het gebureaucratiseerde zorgaanbod van de manager voelt de professional zich niet thuis. Onvrede en leegloop zijn het gevolg, vooral in de verpleegkundige beroepsgroep" (Hillmann \& Most 200ra: Io). Verplegenden en verzorgenden raken gefrustreerd omdat ze zich betrokken voelen bij zorgvragers, maar vervolgens niet die zorg kunnen geven die ze als goed ervaren. Volgens Van Dartel (I999b) is er sprake van een normatief conflict in de zorg. Wanneer verplegenden en verzorgenden andere opvattingen over goede zorg hebben dan de middelen en menskracht die hen door het management ter beschikking worden gesteld, kan dit tot grote frustraties leiden. Door het persoonlijke contact met zorgontvangers zouden verplegenden en verzorgenden andere opvattingen van goede zorg kunnen hebben dan managers. Opvattingen van managers zijn vaak met name gericht op het zo effectief en efficiënt mogelijk aanbieden van het product 'zorg', terwijl verplegenden en verzorgenden dit aanvullen met persoonlijk contact. Verplegenden en verzorgenden kunnen ook andere opvattingen over goede zorg hebben dan artsen, terwijl die voor een belangrijk deel de speelruimte bepalen waarin zij voor patiënten kunnen zorgen. 
Recentelijk wordt frustraties, stress en burn-out onder verplegenden en verzorgenden in verband gebracht met morele ervaringen. Er is aandacht voor hun opvattingen van goede zorg en de ruimte die zij al dan niet ervaren deze opvattingen in de praktijk te brengen. Verschil van mening over wat goede zorg behelst, gebrek aan gelegenheid eigen opvattingen over goede zorg te ventileren en gebrek aan ruimte zorg te geven die zij als goed ervaren, worden genoemd als redenen waarom verplegenden en verzorgenden het vak de rug toe kunnen keren. In dit proefschrift wordt hierbij aangesloten. Tegen deze achtergrond is de volgende aanpak van onderzoek ontwikkeld, om de vraagstellingen te bespreken waarvan in dit boek verslag wordt gedaan.

\section{AANPAK VAN ONDERZOEK}

In deze paragraaf worden de vraagstellingen van dit onderzoek besproken, evenals het theoretisch perspectief en de methoden van dataverzameling.

\section{Vraagstellingen}

In dit boek worden morele ervaringen van verpleegkundigen" met dagelijks zorgverlenen inzichtelijk gemaakt. Daarom wordt ingegaan op de volgende vragen:

Wat verstaan verpleegkundigen onder goede zorg?

Hoe proberen ze deze goede zorg te geven?

Welke problemen komen ze daarbij tegen?

In dit onderzoek worden morele ervaringen van verpleegkundigen verbonden met hun opvattingen van goede zorg, de wijze waarop ze deze proberen te geven en de problemen die ze daarbij tegenkomen. Daarbij wordt uitgegaan van de veronderstelling dat verpleegkundigen morele problemen ervaren, omdat ze zorgvragers niet die zorg kunnen geven die ze zouden willen geven.

\section{Theoretisch perspectief}

Bovengenoemde vragen worden bestudeerd in het perspectief van 'verpleegkundige ethiek'. Ethiek is de stroming binnen de filosofie die zich bezighoudt met moraliteit. De term 'moraliteit' verwijst naar de dagelijkse werkelijkheid van mensen en opvattingen van goed en kwaad die daarin verweven zijn. Ethiek wordt gezien als een reflectie óp moraliteit. Ethiek is het vakgebied dat zich bezig houdt met gedrag van mensen, hun normen en waarden en opvattingen over goed en kwaad, zoals die binnen een bepaalde samenleving of cultuur gangbaar zijn. Verpleegkundige ethiek is vervolgens een stroming die 
zich expliciet richt op een specifiek domein, namelijk de verpleging. Dit vakgebied is daarom bij uitstek geschikt als perspectief om morele ervaringen van verpleegkundigen te bestuderen.

Verpleegkundige ethiek kent verschillende stromingen. Op grond van handboeken en artikelen in de verpleging is de volgende indeling? gekozen: verpleegkundige principe-ethiek, verpleegkundige deugdethiek en zorgethiek. Auteurs binnen deze ethische stromingen zijn onderling met elkaar in debat. Belangrijk onderwerp hierbij is de aandacht voor morele ervaringen van verplegenden op de werkvloer. Met name zorgethici pleiten ervoor om morele ervaringen van zorgverleners centraal te stellen. Voorafgaand aan het empirische onderzoek, dat wordt uitgevoerd om inzicht te verwerven in morele ervaringen van verpleegkundigen, worden deze perspectieven op ethiek onderzocht om te achterhalen hoe ze gebruikt kunnen worden om morele ervaringen van verpleegkundigen op de werkvloer zichtbaar te maken.

\section{Kwalitatieve methoden van onderzoek}

Zoals in het voorafgaande is aangegeven staan in dit onderzoek morele ervaringen van verpleegkundigen met dagelijkse zorgverlening centraal. Om verschillende redenen is daarbij gekozen voor kwalitatieve onderzoeksmethoden.

Kwalitatieve studies ${ }^{10}$ hebben veelal tot doel diepgaand en veelzijdig inzicht te verwerven in gedrag van mensen binnen een bepaalde praktijk. Ze hebben meestal tot doel gedrag van mensen binnen hun eigen sociale en culturcle context te begrijpen. Hierin verschillen de meeste kwalitatieve studies van kwantitatieve analyses, die tot doel hebben gedrag te verklaren of te voorspellen. In kwantitatieve studies worden data verzameld die statistisch kunnen worden bewerkt om percentages vast te stellen, kansen te berekenen of causale verbanden aan te geven. Kwalitatieve studies propageren zogenoemde open manieren van dataverzameling, zoals: participerende observaties en diepteinterviews. Op die manier worden gegevens verzameld over ervaringen en belevingswereld van mensen om bepaald gedrag inzichtelijk te maken en te begrijpen.

Om inzicht te krijgen in morele ervaringen van verpleegkundigen, is een perspectief van binnenuit vruchtbaar. De methode van participerende observatie gecombineerd met informele en formele diepte-interviews is geschikt om de dynamiek van de verpleegkundige praktijk van binnenuit te bestuderen." Deze combinatie wordt tegenwoordig steeds meer toegepast birnen onderzoek naar Nederlandse zorgpraktijken." Het onderzoek waarvan dit boek verslag doet, heeft tot doel morele ervaringen van verpleegkundigen die samenhangen met dagelijks zorgverlenen inzichtelijk te maken. Het gaat erom inzicht te krijgen in hún morele ervaringen: hún opvattingen van goede 
zorg en problematiek die zij ervaren, juist omdát ze goede zorg willen geven. Om deze ervaringen inzichtelijk te maken is het van belang een gedetailleerd beeld te krijgen van de zorg die zij geven en de context waarin zich dat afspeelt. Het gebruik van kwalitatieve onderzoeksmethoden is dan wenselijk.

\section{Doelstellingen}

Belangrijkste doelstelling van dit onderzoek is het verwerven van inzicht in morele ervaringen van verpleegkundigen met dagelijkse zorgverlening. Daartoe worden hun opvattingen van goede zorg voor het voetlicht gebracht, evenals problematiek die zij ervaren wanneer ze proberen goede zorg aan patiënten te geven. Indirect wordt met dit onderzoek daarmee geprobeerd een bijdrage te leveren aan het vergroten van de kwaliteit van werken van verpleegkundigen, waardoor ook de kwaliteit van zorg voor patiënten kan worden verbeterd.

\section{Kwaliteit van werken}

Door morele ervaringen inzichtelijk te maken en te benoemen - ook voor verpleegkundigen zelf - kan hun eigen identiteit, hun gevoel van eigenwaarde en voldoening in het werk worden versterkt." Bovendien kunnen beleidsmakers op grond van deze gegevens rekening houden met deze ervaringen van verpleegkundigen bij het waarderen en faciliteren van zorg. Zoals in de inleiding is aangegeven, wordt met dit onderzoek aangesloten bij de veronderstelling dat verpleegkundigen soms het vak verlaten omdat er te weinig aandacht is voor hun morele ervaringen gericht op het geven van goede zorg aan patiënten. Wanneer beleidsmakers hier meer inzicht in hebben, kunnen ze daarmee rekening houden. Daarom worden ook vanuit morele ervaringen van verpleegkundigen op de werkvloer thema's geformuleerd waaraan verpleegkundige ethiek aandacht moet besteden. Wanneer deze informatie buiten het ethisch vakgebied wordt uitgedragen, kan dit ertoe bijdragen dat de kwaliteit van werken van verplegenden en verzorgenden wordt bevorderd.

\section{Kwaliteit van zorg}

Wanneer er inzicht is in opvattingen van verpleegkundigen over goede zorg, kan dat ertoe bijdragen dat ook de kwaliteit van zorg voor patiënten wordt verbeterd. Opvattingen van goede zorg die zichtbaar zijn kunnen expliciet ingezet worden om de kwaliteit van zorg voor patiënten te verbeteren. Daarnaast kan het denken en handelen van verpleegkundigen vanuit moreel perspectief worden aangescherpt. Wanneer morele ervaringen inzichtelijk zijn, kunnen ze in het kader van verpleegkundige ethiek verder worden bestu- 
deerd en ontwikkeld. Hierbij kan ook kritiek op bestaande opvattingen van goede zorg geleverd worden. Dit inzicht kan ertoe bijdragen dat de kwaliteit van zorg voor patiënten verbetert. Niet alleen omdat daardoor meer ruimte kan komen voor het geven van goede zorg, maar ook omdat waarden en opvattingen aanleiding kurnnen zijn voor reflectie en eventueel kritiek.

\section{HOOFDSTUKINDELING}

In dit boek wordt de volgende route doorlopen om de vraagstellingen van dit onderzoek te bestuderen. In hoofdstuk 2 worden verschillende verpleegkundig ethische perspectieven besproken, namelijk: verpleegkundige principeethiek, verpleegkundige deugdethiek en zorgethiek. Doel daarvan is om een ethisch perspectief te vinden dat bruikbaar is om in het kader van een empirisch onderzoek, morele ervaringen van verpleegkundigen met dagelijkse zorgverlening zichtbaar te maken. In hoofdstuk 3 wordt de keuze voor zorgethiek beargumenteerd en wordt op basis daarvan de vraagstellingen en de aanpak voor het empirische onderzoek verder uitgewerkt. De vraag naar goede zorg wordt, vanuit zorgethisch perspectief, vertaald in de vraag wat patiënten nodig hebben om hun wereld te herstellen of in stand te houden zodat ze er zo goed mogelijk in kunnen leven. In hoofdstuk 4, 5 en 6 worden morele ervaringen van verpleegkundigen beschreven en geanalyseerd. In hoofdstuk 4 worden opvattingen van goede zorg van verpleegkundigen besproken aan de hand van de vraag welke zorgbehoeften volgens hen samenhangen met het herstellen of instandhouden van de wereld, zodat patiënten er zo goed mogelijk in kunnen leven. In hoofdstuk 5 wordt belicht dat tegemoet komen aan zorgbehoeften van patiënten verbonden is met onzekerheid, omdat niet altijd duidelijk is wat een patiënt nodig heeft om zo goed mogelijk in zijn of haar wereld te leven. De aard van deze onzekerheid wordt geanalyseerd. Bovendien komt aan de orde welke kennis en vaardigheden een rol spelen bij het signaleren van en tegemoetkomen aan zorgbehoeften van patiënten. In hoofdstuk 6 worden een aantal situaties besproken waarin volgens verpleegkundigen goede zorg onder spanning staat. Aan de orde komen situaties waarin patiënten er andere opvattingen van goede zorg op nahouden dan verpleegkundigen, situaties waarin artsen voor verpleegkundigen de speelruimte bepalen om goede zorg te geven en situaties waarbij de context van de afdeling belemmerend werkt bij het geven van goede zorg. Ná de empirische hoofdstukken worden in hoofdstuk 7 een aantal thema's geformuleerd waaraan verpleegkundige ethiek aandacht zou moeten besteden, gezien de resultaten van het empirische onderzoek. Daarbij volgt een terugblik op de verpleegkundig ethische theorievorming die in hoofdstuk 2 is 
besprokerı, met name zorgethiek. Hoe is deze ethiek bruikbaar om de onderwerpen die uit het empirisch onderzoek naar voren zijn gekomen, verder uit te werken? In hoofdstuk 8 worden deze thema's in een breder perspectief geplaatst. Waar en hoe kunnen voornoemde thema's aan de orde worde? gesteld, om meer recht te doen aan morele ervaringen van verpleegkundige? op de werkvloer? 


\section{VERPLEEGKUNDIGE ETHIEK}

In dit boek worden morele ervaringen van verpleegkundigen zichtbaar gemaakt. Zoals in hoofdstuk I is aangegeven wordt daarbij gebruik gemaakt van verpleegkundige ethiek, omdat hierin een taal geboden wordt om over moraal te spreken. In ethiek worden opvattingen over juist en onjuist handelen en over goed en kwaad bestudeerd. Ethiek houdt zich met name bezig met de vraag hoe wij mensen moeten zijn en met elkaar om moeten gaan om voor eenieder een goed leven te bevorderen. Verpleegkundige ethiek richt zich daarbij expliciet op de verpleegkundige praktijk en gaat in op de vraag hoe verplegenden op een moreel verantwoorde manier met zorgontvangers om kunnen of moeten gaan.

In dit hoofdstuk wordt de aard en inhoud van verpleegkundige ethiek besproken, die in haar opzet en inhoud verschilt van de manier waarop in andere ethische vakgebieden over morele kwesties wordt gesproken. Doel van dit hoofdstuk is om binnen verpleegkundig ethische stromingen, aanknopings. punten te vinden om morele ervaringen van verpleegkundigen inzichtelijk tt. maken. Er is gekozen voor een specifieke verpleegkundig ethische invalshoek, omdat het vocabulaire uit deze stromingen in de praktijk ook gebruikt wordt om morele kwesties binnen de verpleging zichtbaar te maken en te bespreken. In dit hoofdstuk wordt niet ingegaan op medisch ethiek, gezondheidsethiek of filosofische ethiek in het algemeen. De verpleegkundige ethiek staat centraal.

Binnen de verpleegkundige ethiek bestaat geen overeenstemming over de vraag hoe morele kwesties binnen de verpleging en verzorging besproken moeten worden. Met name de afgelopen decennia wordt intensief gedebatteerd over de vraag hoe morele kwesties in de zorg moeten worden belicht. Alhoewel een scala aan standpunten wordt ingebracht, waarbinnen allerlei nuancen zijn te onderscheiden, zijn deze standpunten op hoofdlijnen in te delen in drie stromingen, die het morele karakter van verplegen en verzorgen ieder op een bepaalde manier conceptualiseren. In handboeken en artikelen over verpleegkundige ethiek, die vanaf 1980 zijn verschenen in het Nederlands en Angelsaksisch taalgebied kunnen op hoofdlijnen de volgende stromingen worden onderscheiden, namelijk: verpleegkundige principe-ethiek, verpleegkundige deugdethiek en zorgethiek.' 
Vanaf 1980 is een ethiek dominant die vooral regels geeft voor het toepassen van algemeen ethische principes om afzonderlijke handelingsvraagstukken op te lossen. Principes als goed-doen, niet-schaden, autonomie of rechtvaardigheid, worden toegepast op morele kwesties. Hierbij wordt binnen de verpleging het gebruik van methodische stappenplannen sterk gepropageerc. Deze ethiek wordt in dit hoofdstuk als verpleegkundige principe-ethiek benoemc. Deze opvatting van verpleegkundige ethiek komt in paragraaf I aan de ord $\epsilon$.

Een aantal auteurs binnen de verpleging ageert tegen dit principe-ethisch: perspectief, omdat zij vinden dat daarin te weinig aandacht is voor het persoonlijke contact tussen verpleegkundige en patiënt. Deze auteurs sluiten aan bij een traditie binnen de verpleging die teruggaat tot Florence Nightingale en die vóór de opkomst van de principe-ethiek in 1980 dominant was binnen d, verpleging. Deze auteurs worden in dit hoofdstuk samengebracht onder de noemer van verpleegkundige deugdethiek, omdat zij zich bezighouden met de vraag welke deugden verpleegkundigen nodig hebben om goede zorg te verlenen. Wat is de houding die verpleegkundigen ten opzichte van patiënten moeten aannemen om goede zorg te geven? In deze deugdethische traditie binnen de verpleging, wordt verpleegkundigen geleerd wat goed is om te

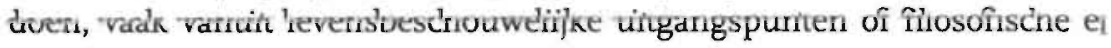
historische studies over goede zorg. In dit opzicht verschilt verpleegkundig: deugdethiek ook van een stroming binnen de verpleging die zorgethiek worc genoemd. De volgende stroming.

Een derde ethische stroming uit de verpleegkundige ethiek die in d: hoofdstuk wordt besproken is zorgethiek. Deze bouwt binnen de verplegin; voort op het denken in termen van deugden. Auteurs die in eerste instanti. met name aansloten bij deugdethiek, kunnen in hun recentere werk wordei ondergebracht onder de noemer van zorgethiek. Op twee punten verschilt $d$. zorgethiek van deugdethiek in de verpleging. Op de eerste plaats wordt bin nen de zorgethiek ervan uitgegaan dat zorg niet zonder meer goed is al verpleegkundigen over de juiste deugden beschikken. Dat wil immers no; lang niet altijd zeggen dat zorg ook op een ethisch verantwoorde manie wordt uitgevoerd. Om te bestuderen of zorg goed is, moet ook de handelin: zelf - de activiteit van het zorgen - in ogenschouw worden genomen. Op d. tweede plaats stellen zorgethici dat het aanleren van deze deugden primai verbonden is met het zorgen zelf. In de concrete activiteit van het zorg, bin nen de interactie tussen verpleegkundigen en patiënt, worden deugden voo goede zorgverlening geleerd en wordt duidelijk welke deugden verpleegkun digen binnen specifieke praktijken nodig hebben om goede zorg te verlenen In deze traditie staan daarom ook niet levensbeschouwelijke, filosofische 0 historische studies over goede zorg centraal, maar wordt praktijkonderzoel uitgevoerd om opvattingen van goede zorg te achterhalen, evenals deugder 
van goede zorgverlening. In tegenstelling tot de principe-ethiek en deugdethiek staat deze opvatting van ethiek binnen de verpleging nog in de kinderschoenen. Bij het bespreken van de zorgethiek in paragraaf 3 , wordt daarom ook gebruik gemaakt van literatuur van buiten de verpleging.

Doel van dit hoofdstuk is om een theoretisch perspectief te kiezen, dat bruikbaar is om in een empirisch onderzoek morele ervaringen van verpleegkundigen met dagelijkse zorgverlening inzichtelijk te maken. Daarom worden de drie stromingen binnen de verpleegkundige ethiek besproken aan de hand van twee vragen. Op de eerste plaats wordt bestudeerd welke kwesties als moreel worden benoemd. Wat geldt als een moreel probleem en wat niet? Daarmee kan zichtbaar worden welke aspecten van de verpleging de aandacht krijgen en welke niet? Op de tweede plaats wordt ingegaan op de vraag welke handreikingen een perspectief geeft om morele kwesties goed te hanteren. Welke kennis en vaardigheden hebben verpleegkundigen nodig binnen een specifiek perspectief op ethiek, om morele kwesties goed te hanteren? Op basis van de antwoorden op deze vragen wordt in het volgende hoofdstuk beargumenteerd waarom met name zorgethiek bruikbaar is als perspectief vocr een empirisch onderzoek naar dagelijkse morele ervaringen van verpleegkundigen op de werkvloer. In bijlage A zijn deze verschillende stromingen binnen verpleegkundige ethiek schematisch uitgewerkt en naast elkaar gezet.

\section{VERPLEEGKUNIGE PRINCIPE-ETHIEK}

In deze paragraaf wordt het perspectief op verpleegkundige ethiek besproken dat het systematisch toepassen van ethische principes ceritraal stelt: verpleegkundige principe-ethiek. In de manier waarop kwesties worden geformuleerd, zit het goed hanteren ervan reeds besloten. In het eerste deel van deze paragraaf komt vooral de vorm aan de orde waarin morele problematiek wordt gegoten. In het tweede deel van deze paragraaf worden de handvatten belicht die volgens dit perspectief nodig zijn om morele problematiek goed te hanteren.

\section{Morele problematiek}

Net als in de medische ethiek spelen ook binnen de verpleegkundige ethiek een aantal centrale waarden en normen een rol, die tegenwoordig in een aantal principes zijn samengevat': weldoen, niet-schaden, respect voor autonomie en rechtvaardigheid. Deze vier principes worden gezien als een samenvatting van allerlei belangrijke waarden, normen, rechten en plichten binnen de 
gezondheidszorg. De centrale rol van deze algemeen aanvaarde ethische principes, is ook zichtbaar binnen de verpleegkundige ethiek, bijvoorbeeld in het werk van Davis en Aroskar (I978) dat in brede kring wordt beschouwd als eerste en meest toonaangevende publicatie op het gebied van ethiek in de verpleging. Het perspectief op ethiek dat zij voorstellen is paradigmatisch voor vervolgpublicaties op dit gebied, zowel in het Angelsaksisch taalgebied' als in Nederland ${ }^{4}$. De verschillende beroepscodes voor verpleegkundigen die zich vanaf die tijd ontwikkelen, zijn eveneens gebaseerd op een dergelijk ethisch perspectief.' Davis en Aroskar zeggen over hun verpleegkundig perspectief op ethiek dat "The format which follows presents a definition and overview of that branch of ethics specific to the health sciences, called ... biomedical ethics and draws implications for the nursing role" (p.viii). Het perspectief op ethiek dat zij voorstellen heeft dezelfde vorm en inhoud als het medisch ethische perspectief, alleen het toepassingsgebied is anders, namelijk: de verpleging.

\section{Conflicterende principes}

In artikelen en handboeken die vanuit verpleegkundig perspectief geschreven zijn, is in eerste instantie vooral aandacht voor morele kwesties die veraf staan van de zorg die verpleegkundigen op de werkvloer aan patiënten geven. Issues als kunstmatige bevruchting, orale anticonceptie, abortus, euthanasie, reanimatie, en dergelijke, worden bestudeerd. ${ }^{6}$ Het bespreken van dergelijke kwesties wordt bekritiseerd door auteurs uit de verpleegkundige principeethiek zelf, omdat dergelijke kwesties vooral de verantwoordelijkheid zijn van artsen.' Volgens hen is het zinvol om aandacht te besteden aan de rol van verpleegkundigen bij het hanteren van morele problematiek en inzicht te verschaffen in beweegredenen van artsen, maar moet verpleegkundige ethiek toch vooral aandacht besteden aan kwesties die verpleegkundigen tegen komen in de zorg. Een dergelijke opvatting wordt niet door iedereen gedeeld. De vooraanstaand medisch ethicus Veatch (198I) stelt bijvoorbeeld dat verpleegkundigen geen andere morele kwesties tegenkomen dan artsen en dat het daarom niet nodig is binnen ethiek een eigen afdeling voor verplegenden en verzorgenden te creëren. "There is really very little that is morally unique to nursing" (p.7).

Het type kwesties dat wordt besproken binnen verpleegkundige principeethiek is in de loop der jaren veranderd. Tegenwoordig is veel meer aandacht voor morele kwesties die zich dichter afspelen bij de directe zorg die verpleegkundigen geven.

Er worden kwesties besproken die te maken hebben met privacy van zorgvragers. Hierbij is bijvoorbeeld aandacht voor de fysieke privacy van patiënten: het dichttrekken van een gordijn of ervoor zorgen dat een gesprek niet door 
anderen gehoord kan worden. Bovendien is er aandacht voor het beschermen van privacy van schriftelijke informatie van cliënten.

Casuistiek die wordt besproken in het kader van ethiek gaat ook over de vraag hoe eigen waarden van hulpverleners zich verhouden tot waarden van patiënten. Hoe kunnen verpleegkundigen ervoor waken dat hun eigen opvattingen van goede zorg prevaleren boven voorkeuren van patiënten? Hoe kunnen verpleegkundigen opvattingen van mensen uit andere culturen respecteren? Wat betekent het in algemene zin, om zorgvragers te respecteren?

Het gaat ook om vragen die te maken hebben met de eigen verantwoordelijkheid van verpleegden. Hoe ver mogen verpleegkundigen gaan in hun bemoeienis met het leven van patiënten of cliënten? Mogen ze familie die ruziet de toegang tot de patiënt weigeren? Hoe om te gaan met patiënten die zich afhankelijk opstellen van verpleegkundigen en alle verantwoordelijkheid uit handen geven? Wanneer is ingrijpen gerechtvaardigd? Wanneer een patiënt zichzelf schade toebrengt? Kun je een patiënt die chemotherapie krijgt, verbieden naar de ontspanningsruimte te gaan om te roken?

In de verpleegkundige principe-ethiek is ook aandacht voor de rol die verpleegkundigen spelen in de relatie tussen een patiënt en een arts. Het gaat dan over geïnformeerde toestemming in het kader van de behandeling. Er wordt gesproken over casuïstiek waarin een patiënt onvoldoende is ingelicht over een wetenschappelijk onderzoek of over de eigen behandeling. De kwaliteit van de toestemming wordt besproken. Heeft de patiënt daadwerkelijk begrepen waar hij of zij toestemming voor heeft gegeven? Morele kwesties als deze worden besproken in handboeken en artikelen over verpleegkundige ethiek die zijn geschreven vanuit een principe-ethisch perspectief (zie noot 2, 34 ).

Dergelijke kwesties, als hierboven genoemd, staan dichter bij de zorg die verpleegkundigen geven dan problematiek rondom abortus, euthanasie of zelfdoding, die in de beginjaren van verpleegkundige principe-ethiek de aandacht krijgen.

De bespreking van bovengenoemde morele kwesties krijgt in de verpleegkundige principe-ethiek vorm aan de hand van ethische principes of de waarden, normen, rechten of plichten die daaraan ten grondslag liggen. Concrete casuistiek wordt vertaald in algemene ethische termen. Vanuit de praktijk wordt geabstraheerd naar ethische principes. Een voorbeeld hiervan is de bespreking van de volgende casus in een ethisch handboek.

"Mevrouw De Vlieg is een angstige en labiele vrouw, bij wie een ernstigc ziekte is ontdekt. De medici denken, dat ze er waarschijnlijk binnen enkele weken aan zal overlijden. Om haar psychisch niet te overbelasten, vertelt de behandelende arts niets over de slechte prognose. Maar mevrouw De Vlieg vraagt wel regelmatig aan één van de verpleegkundigen hoe lang de behandeling nog duurt en of de dokter nog wat gezegd heeft." (Tenwolde r998: 53). 
Het probleem dat hier aan de orde is, zal voor veel verpleegkundigen herkenbaar zijn. Het gaat in dit voorbeeld om patiënten die informatie vragen over hun ziekte en behandeling, maar waarbij de arts veronderstelt dat de patiënt. informatie over een slechte prognose niet zal kunnen verwerken en derhalve beantwoording van de vraag vermijdt. Dit stelt verpleegkundigen voor problemen omdat zij geconfronteerd worden met vragen van de patiënt die zij vervolgens niet adequaat kunnen en mogen beantwoorden. De auteur becommentarieert de casus in termen van de verschillende principes die in dit voorbeeld aan de orde zijn. Hij stelt "de waarden weldoen ... tegenover het recht op informatie, dat bij zelfbeschikking hoort" (Tenwolde 1998: 53). Het probleem van mevrouw De Vlieg wordt vertaald in een conflict tussen de principes van 'weldoen en voorzichtigheid' aan de ene kant en 'recht op informatie en zelfbeschikking' aan de andere kant.

In het kader van verpleegkundige principe-ethiek worden morele kwesties vertaald in termen van morele principes. Probleem daarbij is dat verschillende principes met elkaar kunnen botsen. Vaak is niet zonder meer duidelijk welk principe de doorslag moet geven of kunnen verschillende betrokkenen daarover van mening verschillen.

Met name het botsen van het principe 'weldoen' aan de ene kant en 'respect voor autonomie' van patiënten aan de andere kant, krijgt in verpleegkundige principe-ethiek de aandacht. Hoewel van verplegenden wordt verwacht dat ze zorg bieden die voldoet aan professionele standaarden, is het daarbij niet de bedoeling voorbij te gaan aan eigen wensen van zorgvragers. Bij het botsen van deze principes wordt aan 'respect voor autonomie' veel waarde gehecht. Ook morele kwesties die op het eerste gezicht niet met respect voor autonomie van doen hebben, worden vaak gecentreerd rondom dit principe. Dat is bijvoorbeeld het geval als gesproken wordt over de vraag hoe verpleegkundigen patiënten kunnen respecteren. Respect wordt door Tenwolde (1998) aangewezen als de kern van het verplegen. Hierbij krijgt dit concept vooral de betekenis van 'respect opbrengen voor eigen voorkeuren en besluiten van zorgvragers'. Dat geldt ook voor het respecteren van cultuurverschillen. Tenwolde zegt daarover "Ook al zijn gesprekken en de naar voren gebrachte waarden anders dan autochtone, toch is dit dilemma niet anders dan de andere dilemma's rond autonomie" (Tenwolde 1998: 42).

De centrale rol van het principe van 'respect voor autonomie' binnen verpleegkundige ethiek is bijvoorbeeld ook terug te vinden als gesproken wordt over de verpleegkundige-patiënt relatie. De relatie tussen verpleegkundige en patiënt wordt voorgesteld als een contract, waarbij gelijkwaardige en autonome individuen afspraken maken over de inhoud van de zorg. Er wordt vanuit gegaan dat, hoewel zorgvragers op sommige vlakken in hun leven afhankelijk zijn van de zorg van verpleegkundigen, dit niet betekent 
dat ze niet over hun eigen leven kunnen beschikken. Bovendien moeten verpleegkundigen ervoor zorgen dat, wanneer keuzes van zorgvragers moeten worden overgenomen, zij hun keuzevrijheid snel weer terugkrijgen. Verpleegkundigen zijn ervoor verantwoordelijk dat zij zo snel mogelijk weer onafhankelijk worden. Zelfbeschikking wordt gezien als belangrijkste leidraad om de verhouding tussen verpleegkundige en patiënt vorm te geven.

\section{Autonomie als zelfbeschikkingsrecht}

Niet alleen binnen de verpleging maar binnen de gezondheidzorg in het algemeen krijgen kwesties waarin eigen wensen van patiënten in het geding zijn veel de aandacht." Deze aandacht wordt verantwoord door te verwijzen naar een paternalistische houding van zorgverleners, die besluiten namen vóór patiënten zonder dat ze daar inspraak in gaven. Dit paternalisme werd tot ongeveer 50 jaar geleden gerechtvaardigd door te stellen dat zorgverleners beter wisten wat goed was voor hun patiënten, omdat zij meer medische kennis en inzicht hadden. ${ }^{10}$ Met een verwijzing naar veranderingen in onze maatschappij, democratiseringstendensen en emancipatieprocessen, wordt tegenwoordig een andere verhouding tussen zorgverlener en zorgontvanger gepropageerd. Tegenwoordig worden waarden die te maken hebben met autonomie van mensen, zoals keuzevrijheid en bescherming van de persoonlijke levenssfeer van de patiënt, gezien als de waarden die bij uitstek moeten worden nagestreefd. Patiënten moeten bijvoorbeeld toestemming geven voor de zorg en behandeling die ze ontvangen en de privacy van patiënten moet worden beschermd.

Autonomie wordt in het kader van verpleegkundige principe-ethiek opgevat als het recht van patiënten op zelfbeschikking. "Een dergelijke opvatting van autonomie is ook vastgelegd binnen de gezondheidszorgwetgeving. De Wet op Geneeskundige BehandelingsOvereenkomst (WGBO) ${ }^{12}$ bijvoorbeeld die ook van toepassing is op verpleegkundige zorgverlening, bevestigt het standpunt dat patiënten zelf hun zorg en behandeling moeten kunnen kiezen. In verpleegkundige principe-ethiek krijgt het principe 'respect voor autonomie' de betekenis van het beschermen van keuzevrijheid of zelfbeschikkingsrecht. ${ }^{13}$ Tenwolde formuleert dit als volgt:

"Wie de gevolgen van een besluit ondervindt, heeft er recht op deel te nemen aan de besluitvorming. Ben je de enige die de gevolgen moet dragen, dan dien je ook als enige het desbetreffende besluit te kunnen nemen. Dat is de kern van wat we bedoelen met autonomie of zelfbeschikking." (Tenwolde I998: II verwijst naar Elander).

Het gaat er om dat patiënten in alle vrijheid en zonder dwang van buitenaf beslissingen moeten kunnen nemen. Het principe van 'respect voor autonomie', in de betekenis van zelfbeschikkingsrecht, wil patiënten beschermen 
tegen ongewilde interventies van verpleegkundigen en andere werkers in de gezondheidszorg en tegen ongewilde inmenging van familie.

Aan het zelfbeschikkingsrecht van patiënten wordt in onze huidige westerse samenleving en in onze gezondheidszorg veel waarde toegekend. Tegelijkertijd wordt van zorgverleners verwacht dat zij aan patiënten zorg bieden die voldoet aan de laatste, liefst wetenschappelijk bewezen professionele standaarden. Deze beide uitgangspunten van zorg kunnen met elkaar botsen, wanneer patiënten iets van zorgverleners vragen dat volgens hen niet bijdraagt aan het bevorderen van de gezondheid.

\section{Conflicten rondom zelfbeschikkingsrecht}

In het kader van verpleegkundige principe-ethiek is er vooral aandacht voor situaties waarin de autonomie van patiënten geschonden dreigt te worden. Daarbij gaat het vooral om de vraag of het principe 'weldoen' mag prevaleren boven 'respect voor autonomie'. Mag aan wensen van patiënten voorbij gegaan worden door deze tegen hun zin te behandelen of te verzorgen omdat daardoor de omstandigheden waarin ze zich bevinden of hun gezondheid zal verbeteren? In de bestudeerde verpleegkundig ethische handboeken (zie noot 2, 3 en 4) worden met name vier typen situaties besproken waarin dit dilemma aan de orde is. Wanneer mag autonomie van patiënten geschonden worden om deze, tegen zijn zin in, te helpen?

Op de eerste plaats gaat het om casuistiek waarin dwang aan de orde is. Dwang op patiënten uitoefenen om hen te helpen (weldoen) mag alleen in bijzondere omstandigheden, namelijk als een patiënt een ernstig gevaar voor zichzelf of zijn of haar omgeving is. In de handboeken wordt in dit verband ook verwezen naar de wetgeving, bijvoorbeeld de Wet Bijzondere Opneming Psychiatrische Ziekenhuizen (BOPZ) waarin dat is vastgelegd. ${ }^{4}$

Op de tweede plaats wordt in het kader van verpleegkundig principeethiek casuïstiek besproken waarin patiënten weliswaar geen gevaar vormen voor hun omgeving, maar waarbij een patiënt last of onrust veroorzaakt. In deze casuistiek gaat het om het afwegen van de omvang en emst van de last, ten opzichte van het belang dat wordt gehecht aan de vrijheid of welzijn van andere patiënten (en van verpleegkundigen). Vrijheid en welzijn van de ene patiënt kan ten koste gaan van vrijheid en welzijn van de andere patiënt.

Ten derde wordt in de handboeken een categorie 'problematische situaties' genoemd, waarbij het gaat om de vraag 'wanneer is een patiënt een gevaar voor zichzelf?'. Het gaat dan niet zo zeer om ernstig gevaar in de vorm van suīcidaal gedrag, maar vooral om situaties waarin patiënten gedrag vertonen dat, volgens zorgverleners, ongezond voor hem of haar is. Bijvoorbeeld als een patiënt wil roken terwijl hij of zij een chemokuur krijgt. Binnen verpleegkundig ethische literatuur wordt deze derde categorie 'problematische 
situaties' in het kader van 'recht op zelfbeschikking van patiënten' met name geconceptualiseerd als een botsing tussen het principe van 'weldoen' of 'niet schaden' en het 'zelfbeschikkingsrecht van patiënten'. De professionele deskundigheid van verpleegkundigen speelt in de afweging van deze principes een belangrijke rol. Bij het bespreken van dergelijke casuistiek worden de principes 'weldoen' en 'niet-schaden' nauw verbonden met de opdracht tot verpleegkundige zorgverlening. Weldoen krijgt daarbij een specifieke betekenis. "Weldoen... dat is voor de verpleging en verzorging al gauw: de gezondheid behouden, het herstel bevorderen en schade voorkomen" (Tenwolde 1998: 15). Er zijn casus waarin een dergelijke als professioneel benoemde waarde van 'weldoen' leidt tot problemen. Het gaat dan om situaties waarin patiënten gedrag vertonen dat volgens verpleegkundigen, vanuit hun professionele deskundigheid, niet goed voor hen is en hun dus, 'niet weldoet' of 'schade toebrengt'. Bijvoorbeeld wanneer patiënten activiteiten willen verrichten, die hun gezondheid ondermijnen. Aan de ene kant staat dan de professionele verpleegkundige die deskundigheid heeft met betrekking tot de vraag welke risico's iemand loopt of hoe groot de schade is. Aan de andere kant staat de patiënt, die zelf wel weet wat goed voor hem of haar is, of andere opvattingen van gezondheid heeft, of besluit om iets anders belangrijker te vinden dan gezondheid. De ingeschatte zwaarte van de schade of de grootte van het risico, met name als het gaat om ernstige lichamelijke schade, krijgen bij deze afweging een belangrijke rol.

Bij bovengenoemde problematische situaties staat de wilsbekwaamheid van patiënten niet ter discussie. Dat is wel het geval bij een vierde categorie casuistiek die in verpleegkundige principe-ethiek wordt besproken, in verband met het inperken van zelfbeschikking van patiënten ten gunst van weldoen. Wilsonbekwame patiënten worden, met een verwijzing naar wetgeving zoals BOPZ en WGBO, opgevat als patiënten die onvoldoende in staat zijn de informatie die ze krijgen te overzien en te verwerken en onvoldoende in staat zijn hierover na te denken, te redeneren en beslissingen te nemen. Bij wilsonbekwame patiënten mag het nemen van beslissingen worden overgenomen, bij voorkeur door de aangewezen vertegenwoordiger of belangenbehartiger. Vaak wordt casuistiek waarin het gaat om wilsonbekwame patiënten geplaatst in de context van zorg voor verstandelijk gehandicapten, psychiatrische of geriatrische patiënten. In dit verband wordt ook over partieel paternalisme gesproken. Dit wordt omschreven als een vorm van besluitvorming, waarbij sommige beslissingen wel maar andere niet van zorgontvangers worden overgenomen. Wanneer patiënten sommige zogenaamde grote beslissingen niet kunnen nemen, bijvoorbeeld ten aanzien van opname of behandeling, wil dat nog niet zeggen dat patiënten ook geen beslissingen kunnen nemen 
over wat ze willen eten, welke kleren ze aan willen of welke activiteiten ze willen verrichten.

In het voorgaande is besproken dat in het kader van verpleegkundige principe ethiek. morele problematiek op een bepaalde manier in beeld wordt gebracht. Op de eerste plaats wordt een situatie als problematisch gedefinieerd wanneer ethische principes met elkaar botsen. Op de tweede plaats worden kwesties die niet direct met ethische principes in verband gebracht hoeven te worden (zoals bijvoorbeeld de verpleegkundige-patiënt relatie, respect en cultuurverschillen) wel in dergelijke termen besproken. Op de derde plaats worden met name die kwesties aan de orde gesteld waarin zelfbeschikkingsrecht van patienten moet worden gewogen ten opzichte van het principe 'weldoen'. In de gezondheidszorg en binnen de verpleging is het handelen erop gericht optimale zorg en behandeling aan patiënten te bieden. Tegelijkertijd dient daarbij de stem van patiënten zelf de doorslag te geven. Deze combinatie is niet altijd gemakkelijk. Toch is het uitdrukkelijk niet de bedoeling dat zorgverleners besluiten nemen vóór patiënten, ook al gebeurt dat met de beste bedoelingen en vanuit de laatste professionele standaarden, tenzij patiënten onbekwaam zijn of veel onrust veroorzaken.

\section{Hanteren van morele problematiek}

In het tweede deel van deze paragraaf worden besluitvormingsmodellen aan de orde gesteld, die in het kader van verpleegkundige principe-ethiek aan verplegenden en verzorgenden aangereikt worden om morele kwesties goed te hanteren. Het gaat erom verpleegkundigen te leren hoe ze principes zo goed mogelijk op een problematische situatie kunnen toepassen. Hoe kunnen principes leidraad zijn voor goed handelen? Bij het besprekeri van deze besluitvormingsmodellen in deze paragraaf, worden ook kwesties aan de orde gesteld waarin het zelfbeschikkingsrecht van patiënten in het geding is, omdat dergelijke problematiek veel aandacht krijgt binnen verpleegkundige principe-ethiek.

\section{Besluitvormingsmodellen}

In de verpleegkundige principe-ethiek staan afzonderlijke handelingsvraagstukken centraal waarin verschillende principes met elkaar botsen. Daarbij is het de bedoeling om deze principes ten opzichte van elkaar te wegen en vervolgens te bepalen welk principe de leidraad moet zijn voor het handelen. Wanneer een patiënt tegen zijn zin bij de wasbak wordt achtergelaten, omdat deze patiënt binnenkort naar huis gaat en de verpleegkundige ervan uitgaat dat hij of zij daarom weer zo veel mogelijk voor zichzelf moet zorgen, laat zij 
het principe van weldoen zwaarder wegen dan het principe van respect voor autonomie.

Wat problematisch is bij het wegen van principes die met elkaar botsen, is dat daarbij meestal niet vanzelfsprekend is welk principe leidraad voor handelen moet zijn. Principeś kunnen strijdig zijn en betrokkenen kunnen een verschillende mening hebben over de waarde van principes. Bovendien spelen bij het wegen van principes vaak persoonlijke belangen een rol, die zo veel mogelijk van deze weging uitgesloten moeten worden. Goede besluitvorming betekent in het kader van verpleegkundige principe-ethiek, een onpartijdige, neutrale en objectieve weging van principes. Om in het kader van de verpleging de kwaliteit van ethische besluitvorming te vergroten, wordt daarom aan verpleegkundigen een methode aangereikt.

Belangrijk doel van verpleegkundige principe-ethiek is juist om de kwaliteit van ethisch redeneren te vergroten. "Het is onvoldoende dat iedereen roept wat hij of zij vindt of voelt, of dat louter eigen belangen worden nagestreefd. Ethiek is systematisch nadenken over morele vraagstukken. Dat vereist een methodische aanpak" (Meykamp et al. 1992: 34). Stappenplannen zijn een belangrijk instrument om het methodisch en systematisch nadenken over ethische vraagstukken bij verpleegkundigen te bevorderen. In ieder handboek voor verpleegkundige ethiek is een model ter ondersteuning en sturing van ethische besluitvorming terug te vinden. ${ }^{15}$ Het boek van Thompson en Thompson (198I) geldt als standaardwerk als het gaat om stappenplannen. ${ }^{16}$ Dit werk wordt overvloedig geciteerd in allerlei artikelen en boeken. Door Thompson en Thompson worden principes voorgesteld om handelingsvraagstukken te bespreken en wordt een stappenplan beschreven dat dient ter ondersteuning van het toepassen van deze principes. Om het methodisch benaderen van ethische vraagstukken te bevorderen wordt daarnaast ook gebruik gemaakt van denkkaders als deontologie of teleologie (consequentialisme). In het eerste denkkader worden overwegingen gestuurd door tegenstrijdigheid van plichten te bespreken en wegen. In een teleologisch denkkader gaat de aandacht uit naar de uitkomsten van bepaalde handelingsstrategieën en worden deze ten opzichte van elkaar gewogen. Het vaststellen en wegen van plichten of handelingsopties speelt zich vervolgens af binnen de voorgestelde stappenplannen.

Een stappenplan omvat een aantal stadia die systematisch doorlopen moeten worden. ${ }^{17}$ De bedoeling is om de feiten van waarden, normen, rechten of plichten te onderscheiden. Deze laatste moeten onderwerp van discussie zijn. Daarom moeten eerst de feiten objectief op een rijtje worden gezet, waarna de ethische dimensie eruit kan worden gelicht. De bedoeling is om normen, waarden, rechten of plichten van verschillende betrokkenen uit te filteren, zodat deze vervolgens ten opzichte van elkaar gewogen kunnen wor- 
den. Het stappenplan moet antwoord geven op de volgende vragen: wat is er aan de hand? welke waarden zijn in een problematische situatie in het geding? wie is er formeel verantwoordelijk? hoe verhoudt dit zich tot belangen van de verschillende betrokkenen? Aan de hand van het uitwerken van verschillende handelingsalternatieven, waarbij voor-en nadelen worden gewogen, kan uiteindelijk bepaald worden wat goed is om te doen.

"Wij geloven dat ... men ethische theorie leert toepassen op morele problemen door middel van een 'stappenplan' dat het afwegingsproces bij moeilijke beslissingen ordent. Dat verkleint de kans op een bevooroordeelde en onvolledige afweging." (Van den Hoven \& Tenwolde 1988: 107).

Stappenplannen zijn gericht op het vergroten van de kwaliteit van ethische oordelen. Ze zijn bedoeld om op een rechtvaardige manier vast te kunnen stellen welke principes, waarden, normen, rechten of plichten op een bepaald moment de doorslag moeten geven, zodat deze het handelen van betrokkenen kunnen sturen.

Een oordeel wordt rechtvaardig als het onpartijdig en objectief is en zonder aanzien des persoon tot stand komt. Emoties van betrokkenen krijgen daarbij een bepaalde rol toebedeeld. Deze worden met name gezien als een alarmbel, een teken dat er iets aan de hand is. Emoties moeten door betrokkenen serieus genomen worden, omdat deze kunnen wijzen op morele problematiek. Het besluitvormingsproces zelf moet onpartijdig en belangeloos verlopen. Gepoogd wordt daarom emoties van betrokkenen te kanaliseren door het besluitvormingsproces methodisch te laten verlopen, zodat logisch en rationeel denken wordt bevorderd.

Tenwolde (1998) vat de eisen, die gesteld worden aan besluitvorming ten aanzien van ethische problemen waarbij essentiële menselijke belangen in het geding zijn, als volgt samen:

"Ze moet in de eerste plaats expliciet zijn. Aan alle betrokkenen moet kunnen worden uitgelegd hoe een besluit tot stand is gekomen. In de tweede plaats dient de besluitvorming te berusten op geldige redeneringen. Daardoor wordt willekeur vermeden; bovendien kunnen eventuele bezwaren tegen een besluit dan worden gebaseerd op de gebrekkigheid van de aangevoerde argumenten. Ten derde dient de besluitvorming systematisch te verlopen uit een oogpunt van efficiëntie en om nalatigheden van de beslissers te vermijden. De besluitvorming dient ook zorgvuldig te zijn. Dat wil zeggen; de bestede tijd en energie moet in overeenstemming zijn met het belang en inspraak van de belanghebbenden. De laatste eis die we moeten stellen aan morele besluitvorming, is onpartijdigheid; het mag niet uitmaken hoe we staan tegenover de betrokken personen." (Tenwolde 1998: 9r). 


\section{Conflicten rondom zelfbeschikkingsrecht}

Aan het oplossen van conflicten rondom zelfbeschikking wordt in het kader van verpleegkundig principe-ethiek veel aandacht besteed. Bij dergelijke conflicten krijgen verpleegkundigen vaak de taak toegewezen de stem van de patiënt naar voren te brengen en te verhelderen. Zij moeten ervoor zorgen dat patiënten niet 'overruled' worden door andere zorgverleners die patiënten dwingen tot besluiten die patiënten zelf eigenlijk niet willen nemen. Verpleegkundigen moeten voorkomen dat zijzelf of andere hulpverleners of familie, voor patiënten bepalen wat goed voor hen is.

Verpleegkundigen krijgen in het kader van verpleegkundige principeethiek verschillende handvatten aangereikt om het zelfbeschikkingsrecht van patiënten te ondersteunen, zodat het voor patiënten zelf duidelijk kan worden wat voor hen de juiste keuze is. Verpleegkundigen moeten bijvoorbeeld in staat zijn om informatie op een tijdstip en een manier te geven die aansluit bij de persoon van de patiënt en de manier waarop hij of zij informatie kan opnemen, begrijpen en verwerken. Een patiënt kan alleen een autonome keuze maken indien deze zijn of haar situatie, keuzemogelijkheden en consequenties van een handelwijze kan overzien. Daamaast kriigen verpleegkundigen de opdracht ervoor te zorgen dat patiënten keuzes maken die ze werkelijk zelf willen. Wanneer verpleegkundigen in de zorgverlening geconfronteerd worden met patiënten die zeggen iets niet te willen, moeten ze zich niet onmiddellijk neerleggen bij een dergelijke uiting, maar zich afvragen of een dergelijke uiting een impuls is of dat dit samenhangt met diepere voorkeuren en verlangens. Verpleegkundigen moeten patiënten daarom steunen om de zaken in hun verband te zien en de lange termijn erbij te betrekken. Verondersteld wordt dat op basis daarvan een oppervlakkig gevoeld verlangen en impulsieve voorkeuren kunnen worden onderdrukt, omdat er op een dieper niveau verlangens en voorkeuren zijn die met het oppervlakkige verlangen in strijd kunnen zijn. Verpleegkundigen moeten niet alleen afgaan op expliciet uitgesproken keuzes van een patiënt, maar moeten ook in staat zijn zich een beeld te vormen van diens innerlijke keuze. Om patiënten te steunen daadwerkelijk vrij en autonoom te kiezen moeten verpleegkundigen samen met patiënten proberen te achterhalen wat die werkelijk willen."

In principe-ethiek spelen dus communicatieve vaardigheden van verpleegkundigen en patiënten een belangrijke rol. Deze communicatie is gericht: op het vormgeven en ondersteunen van zelfbeschikking van patiënten. Communiceren is ook van belang in het kader van het geven en ontvangen van kennis. Kennis moet volledig, overzichtelijk en begrijpelijk aan patiënten worden aangereikt. Verpleegkundigen moeten vragen van patiënten zodanig kunnen beantwoorden, dat deze een volledig beeld kunnen krijgen van hun situatie, zodat zij de consequenties van specifieke handelwijzen 
kunnen overzien. Ook wordt communicatie opgevat als een manier om zicht te krijgen op wensen en voorkeuren van patiënten, om een onderscheid te kunnen maken tussen een geuite wens en de daarachter liggende verlangens, om te achterhalen of patiënten een bewuste innerlijke keuze maken. Anders dan in de deugdethiek het geval is, zo wordt in de volgende paragraaf belicht, maken communicatieve vaardigheden in een verpleegkundige principe-ethiek geen deel uit van de ethiek. Het zijn hulpmiddele, om ethische afwegingen te kunnen maken.

In deze paragraaf is verpleegkundige principe-ethiek besproken. Daarbij is zichtbaar geworden welke vorm morele problematiek krijgt en welke handvatten in deze ethiek geboden worden om morele kwesties te hanteren.

Morele problematiek wordt in dit kader geformuleerd in termen van principes. Dat betekent dat met name die kwesties in beeld komen waarin principes met elkaar botsen. Bovendien worden problematische situaties geherformuleerd in termen van principes. De kern van verpleegkundige principe-ethiek is dat ze in dilemma's denkt, waarin verschillende principes met elkaar botsen. Kwesties waarin zelfbeschikkingsrecht van patiënten botst met het principe van 'weldoen' krijgen binnen de verpleging in het bijzonder de aandacht. Verpleegkundigen en andere zorgverleners willen patiënten optimale zorg en behandeling bieden, maar tegelijkertijd eigen wensen van patiënten daarbij als uitgangspunt nemen. Dat kan botsen, omdat patiënten soms iets vragen of doen, dat volgens zorgverleners uit oog. punt van zorg en behandeling, niet wenselijk is.

Om de kwaliteit van ethische besluitvorming te vergroten biedt een verpleegkundige principe-ethiek een systematische, objectieve en onpartijdige denkwijze. Er wordt benadrukt dat verpleegkundigen in staat moeten zijn in algemene termen verantwoording af te leggen over hun beweegredenen, om een handelingsvraagstuk op een bepaalde manier op te lossen. Verpleeg. kundigen moeten een rechtvaardiging kunnen geven voor het handelen. De taal van principes en regels, voor de toepassing vastgelegd in een stappenplan, is een manier om aan deze rechtvaardiging vorm te geven. Wanneer bij conflicten rondom zelfbeschikkingsrecht naar oplossingen wordt gezocht, speelt in de verpleegkundige principe-ethiek de communicatie tussen verpleegkundigen en patiënten een belangrijke rol. Bij het wegen van zelfbeschikkingsrecht ten opzichte van het principe 'weldoen', is het van belang dat patiënten informatie hebben over hun situatie. Voor verpleegkundigen moet duidelijk worden of patiënten daadwerkelijk begrijpen wat er aan de hand is en of zij de keuze voor een bepaalde handelingsoptie kunnen overzien. Bovendien moeten verpleegkundigen door middel van communicatie zicht krijgen op wensen, voorkeuren en verlangens van patiënten. Om zelf- 
beschikkingsrecht van patiënten te ondersteunen, krijgen verpleegkundigen in het kader van verpleegkundige principe-ethiek een belangrijke rol toebedeeld.

\section{VERPLEEGKUNDIGE DEUGDETHIEK}

Tegenwoordig wordt de principe-ethiek binnen de verpleging bekritiseerd." Volgens deze critici moet een ethiek voor de verpleging zich niet zo zeer bezighouden met het bespreken van afzonderlijke handelingsvraagstukken waarin principes met elkaar botsen. Zij vinden dat de persoonlijke kant van het proces van zorg verlenen centraal moet staan, in het kader van verpleegkundige ethiek. Binnen de verpleging wordt daarom door verschillende auteurs hernieuwd aandacht gevraagd voor een ethische traditie die vóór de opkomst van de principe-ethiek dominant was binnen de verpleging, namelijk de deugdethiek.

In deze paragraaf worden opvattingen van een aantal auteurs binnen de verpleging besproken, die in dit boek zijn samengebracht onder de noemer van verpleegkundige deugdethiek. Om de verpleegkundige deugdethiek te bespreken is gebruik gemaakt van ethische publicaties uit het Angelsaksisch taalgebied, ${ }^{20}$ waaronder literatuur uit de Scandinavische landen. ${ }^{21}$ In Nederlandstalige literatuur wordt een deugdethiek voor de verpleging, als kritiek op de principe-ethiek, nauwelijks systematisch uitgewerkt. In handboeken binnen de verpleging (zie noot 3 ) wordt slechts zeer zijdelings melding gemaakt van deugden. Deze worden daarbij meestal in verband gebracht met levensbeschouwelijke uitgangspunten en vooral gezien als een individuele aangelegenheid. Of deugdethiek wordt in verband gebracht met het verleden en niet meer gezien als iets van deze tijd. Het denken in termen van deugden kriigt in Nederlandstalige handboeken en artikelen over verpleegkundige ethiek geen plek van betekenis, wanneer het gaat om de vraag welke kwesties als moreel worden benoemd en hoe deze moeten worden gehanteerd. Ethiek gaat toch vooral over het beoordelen van afzonderlijke handelingsvraagstukken waarin principes botsen. Uitzondering daarop is de auteur Gastmans ${ }^{22}$, wiens werk in deze paragraaf daarom ook aan de orde zal komen.

In deze paragraaf wordt eerst ingegaan op de positie van deugdethiek binnen de verpleging door de tijd heen. Vervolgens worden een aantal hedendaagse opvattingen van verpleegkundig deugdethici besproken. En tot besluit van deze paragraaf wordt aangegeven welke kwesties als moreel worden benoemd, in het kader van verpleegkundige deugdethiek. Voor verschillende auteurs die in deze paragraaf worden besproken, is het denken in termen van deugden een stap geweest richting zorgethiek (paragraaf 4 ). ${ }^{23}$ 


\section{Een traditie van deugden binnen de verpleging}

Ethiek heeft van oudsher deel uitgemaakt van ontwikkelingen binnen het verpleegkundig vakgebied. Deugdethiek in de zorg is reeds onderwerp van gedachtevorming vanaf de eerste publicatie over verplegen in 1859 van Florence Nightingale 'Notes on Nursing'. Nightingale besteedde aandacht aan de morele ontplooiing van verpleegsters. De goede verpleegster beschikte volgens haar over deugden als discipline, gehoorzaamheid en trouw. Daarnaast schetste zij een beeld van de verpleegster als de "goede vrouw'. ".... you cannot be a good nurse without being a good woman, she was fond of saying ... " (Baly 1986: 25). Een andere publicatie uit die tijd waarnaar in het kader van deugdethiek wordt verwezen, is die van Isabel Hampton Robb 'Nursing ethics. For hospital and privat use' uit 1900. In dergelijke publicaties wordt aandacht besteed aan de persoonlijke karaktervorming van verpleegkundigen. Welke deugdzame houding is nodig om goede zorg te kunnen verlenen? Een deugd wordt daarbij opgevat als een bepaalde karaktereigenschap van mensen, die hen in staat stelt het goede te doen.

Voor Nightingale en andere auteurs binnen de verpleging zijn ethiek - in de vorm van deugden - en goede zorgverlening onlosmakelijk met elkaar verbonden. In publicaties over verpleging uit die tijd worden niet alleen taken neergelegd die verpleegsters moeten uitvoeren. Spijker (1979) constateert dat daarnaast uitgebreid aandacht wordt besteed aan de persoonlijke eigenschappen en het karakter van de uitvoerder daarvan. Na I950 krijgen handboeken echter een ander karakter. Deugden voor goede zorgverlening verdwijnen naar de achtergrond en spelen nauwelijks nog een rol bij het overdenken van opvattingen van goede zorg. Het deugdenaspect wordt verdrongen door een functionele en technische aanpak in de zorg.

Door de opkomst van de principe-ethiek in de verpleegkundige literatuur vanaf de jaren tachtig is het denken in termen van deugden binnen de verpleging nog verder in onmin geraakt. De aandacht wordt verplaatst van de ontwikkeling van de persoon, naar de handeling. Niet langer staat de persoon van de verpleegkundige centraal als het gaat om de vraag hoe ervoor gezorgd kan worden dat verplegen moreel verantwoord is. De aandacht gaat uit naar de handeling zelf. Afzonderlijke handelingsvraagstukken worden bestudeerd en beoordeeld aan de hand van algemeen aanvaarde ethische principes.

"... nursing ethics, went from a focus on the good person to focus on the right act. This new paradigm, expressed mainly in principles, uses ethical principles drawn from moral philosophy to structure, address and resolve questions, and has come to dominate health care ethics" (Davis 1995: 355).

In het kader van principe-ethiek wordt het denken in termen van deugden vaak afgedaan als een etiquette. 'Échte' ethiek gaat - bijvoorbeeld volgens 
Arend en Gastmans (1993) - over principes en niet over het persoonlijke karakter van verpleegkundigen en hun deugdzame houding.

De karaktervorming in ethische zin van de verpleegster werd, naast ontwikkeling van gedragsregeis, een centraal punt van discussie in de verpleegkundig-ethische literatuur uit de hier besproken periode. (p. 49) ... Het centraal stellen van etiquette-achtige regels bij de ethische vorming van de verpleegster, in plaats van de toepassing van ethische principes op het handelen als zondanig, blijft tot ongeveer het midden van de twintigste eeuw bepalend voor de ontwikkeling van de ethiek binnen de verpleging. Deze deugd-gerichte aanpak werd gecombineerd met de opstelling van een omvangrijke lijst van concrete gedragsregels voor verpleegsters. Uiteindelijk werd de ethiek als geheel daardoor versmald tot een zaak van beroepsgeboden etiquette, die nog maar weinig te maken had met wat wij tegenwoordig onder een gedegen ethische bezinning verstaan. (p. 50).

Nadat de principe-ethiek zich gevestigd heeft als dominant perspectief binnen de verpleging en de consequenties daarvan voor de zorgverlening zichtbaar worden, is dat voor verschillende auteurs aanleiding opnieuw aandacht te vragen voor deugden van goede zorgverlening. In tegenstelling tot de periode vóór de opkomst van de principe-ethiek staat niet zo zeer de karaktervorming van de van de verpleegkundige op zichzelf centraal, als wel de vraag welke deugden verbonden zijn met de praktijk van het zorgen.

Met haar nadruk op het praktijkgebonden karakter van deugden, sluiten ethici binnen de verpleging aan bij een bredere traditie binnen de deugdethiek die terug te voeren is op het werk van de filosofisch eticus Macintyre (I98I). Het begrip 'deugdethiek' als zodanig komt van Aristoteles (van Tongeren 2003). Binnen de Aristotelische traditie wordt de nadruk gelegd op het aanleren van een deugdzame houding, vanuit de veronderstelling dat individuen in steeds wisselende situaties in staat moeten zijn om het goede na te streven. Wat het goede is om te doen, is volgens Aristoteles namelijk afhankelijk van de specifieke situatie en niet in algemene termen op voorhand vast te leggen. Daarom is het van belang dat individuen een deugdzame houding aanleren, die hen houvast biedt om in steeds nieuwe situaties het goede te doen. MacIntyre heeft deze deugdethische traditie van Aristoteles in een geheel eigen richting omgebogen. In zijn werk wordt de centrale focus gevormd door de interne deugden die met een bepaalde maatschappelijke praktijk zijn verbonden. Deugden zijn volgens MacIntyre karaktereigenschappen die mensen in staat stellen het goede te doen binnen een specifieke praktijk waaraan ze zich gebonden weten. De inhoud van deugden wordt met name bepaald door de gemeenschap waartoe men behoort. Deze gemeenschap bepaalt, in voortdurende onderlinge discussie, wat een deugdzame houding is en wat niet. 
In het kader van verpleegkundige deugdethiek, die ná de opkomst van de principe-ethiek binnen de verpleging wordt besproken, wordt nauw aangesloten bij deze opvattingen van MacIntyre en wordt gezocht naar deugden die samenhangen met de praktijk van het zorgen. Welke deugdzame houding hebben verpleegkundigen nodig om goede zorg te verlenen? Binnen verpleegkundig ethische literatuur wordt op twee manieren gezocht naar een antwoord op deze vraag. Op de eerste plaats zijn er auteurs die conceptuele, filosofische en historische studies verrichten om 'goede zorg' te kunnen omschrijven. Deze auteurs worden in deze paragraaf besproken onder de noemer van 'verpleegkundige deugdethiek'. Op de tweede plaats zijn er auteurs die het antwoord op de vraag naar deugden van goede zorg zoeken binnen concrete praktijken van verpleging en verzorging. Deze auteurs komen in de volgende paragraaf aan de orde, waarin zorgethiek wordt besproken. In dit boek wordt het onderscheid tussen verpleegkundige deugdethiek en zorgethiek met name gesitueerd in de vraag of conceptuele studies het uitgangspunt zijn om een antwoord te zoeken op de vraag wat goed is om te doen of dat dit concrete praktijken van verpleegkundige zorgverlening zijn.

\section{Hedendaagse verpleegkundige deugdethiek}

Met behulp van bijvoorbeeld filosofische en historische analyses van het concept 'goede zorg', wordt in het kader van verpleegkundige deugdethiek getracht de morele dimensie van zorg te expliciteren, om daar deugden voor goede zorg uit af te leiden. Dat heeft geleid tot verschillende opvattingen van goede zorg en daarmee samenhangende deugden.

De waarde van zorg wordt door een aantal deugdethici binnen de verpleging bijvoorbeeld gezocht in haar gerichtheid op het beschermen en bevorderen van de menselijke waardigheid van de patiënt. ${ }^{24}$ 'Waarheid vertellen' en 'aanraking' worden vervolgens benoemd als centrale deugden voor het behouden van deze menselijke waardigheid. Door de waarheid te vertellen helpt de verpleegkundige de patiënt zich aan te passen aan de situatie van het ziek zijn en om keuzes te maken die gebaseerd zijn op de unieke betekenis van het ziek-zijn. Door aanraking helpt de verpleegkundige de patiënt om het onpersoonlijke van de situatie, die vaak zo kenmerkend is voor de ervaring van patiënten in de gezondheidszorg, te overwinnen. Verpleegkundigen helpen patiënten zich geen object te voelen (een maag of een been), maar een persoon. De relatie tussen verpleegkundige en patiënt wordt in dit perspectief van goede zorg gezien als de basis. Alleen wanneer verpleegkundigen bereid zijn om als mens een persoonlijke relatie met een patiënt aan te gaan en bereid zijn emotioneel te investeren in deze relatie, zijn ze in staat om - bijvoorbeeld door middel van de waarheid vertellen of aanraken - de 
mens achter de patiënt als holistische eenheid tegemoet te treden en diens menswaardigheid te beschermen.

Om deugden voor goede zorg te formuleren wordt soms teruggegrepen op het werk van Florence Nightingale. ${ }^{25}$ Tegelijkertijd wordt daarbij benadrukt dat in de huidige praktijk van het zorgen, andere deugden nodig zijn dan toen. Waar bij Florence Nightingale de nadruk lag op het karakter van een goede vrouw (zoals volgzaamheid en dienstbaarheid) en vrouwelijke deugden die nodig zijn om te zorgen (zoals stiptheid, orde en netheid), ligt in hedendaagse zorgpraktijken de nadruk op andere deugden. Sellman (1997) bespreekt onder andere het belang van de deugd van praktische wijsheid voor de praktijk van de verpleging, waarbij deze auteur gebruik maakt van het werk van Aristoteles. Bovendien worden "... to be generous, compassionate and caring" (p. 1o) genoemd als deugden van goede zorgverlening. Een ander verschil tussen opvattingen van hedendaagse deugdethici binnen de verpleging en het werk van Florence Nightingale, is dat Nightingale veronderstelde dat deugden aangeboren kwaliteiten waren, en in het geval van verpleegkundige zorgverlening, aangeboren kwaliteiten van de vrouw. In het kader van de huidige deugdethiek binnen de verpleging wordt meestal niet gesproken over deugden alsof het aangeboren persoonlijke eigenschappen van verpleegkundigen betreft. "Virtues are learned, practiced, cultivated or habituated; they are not a matter of heredity of personality" (Fowler 1986: 528). Deugden hangen samen met specifieke praktijken en kunnen binnen specifieke praktijken worden geleerd.

Op basis van een filosofische studie concluderen Bishop en Scudder (1990) dat de persoonlijke relatie tussen verpleegkundige en patiënt de basis is van goede zorg. Volgens deze auteurs moeten verpleegkundigen patiënten als persoon benaderen met "dignity and respect" (p. II) en moeten zij open staan voor de specifieke persoon van de patiënt. Het doel van de relatie is het bevorderen van het welbevinden van patiënten. De manier waarop verpleegkundigen zich uitdrukken moet passen bij de specifieke situatie van de patiënt en de specifieke relatie tussen verpleegkundige en patiënt.

'Caring' wordt door Bevis (I981) opgevat als een fundamentele deugd van verpleging:

"Caring is a feeling of dedication to another to the extent that it motivates and energizes action to influence life constructively and positively by increasing intimacy and mutual self-actualization." (Bevis 1981: 50).

Goede zorg wordt door deze auteur in verband gebracht met een gevoel van toewijding dat erop gericht is het goede te doen voor een ander. Zorg is een gevoel, dat bijdraagt aan intimiteit en gezamenlijke groei.

Andere auteurs zoeken naar een moreel fundament van goede zorg buiten de verpleging. Het werk van de feministische auteur Noddings (I984) wordt 
bijwoorbeeld door Crowley (1989) gebruikt om ervoor te pleiten, de zorgrelatie op te vatten als het ethisch fundament voor verplegen. Volgens deze auteur is de morele benadering gebaseerd op principes en logisch redeneren inadequaat voor het ontwikkelen van een ethiek voor de verpleging. De praktijk van het moederschap kan aanknopingspunten bieden het ethisch fundament van verplegen te benoemen en deugden voor goede zorgverlening uit te werken.

In het Nederlands taalgebied kenmerkt het werk van Gastmans zich door een zoektocht naar het expliciteren van de morele dimensie van zorg. Door deze auteur wordt zorgzaamheid benoemd als deugd van verpleegkundige zorgverlening. Zorgzaamheid is de essentiële houding van verpleegkundigen. "Zorgzaamheid is het gevoelsmatige en ondersteunende antwoord van de verpleegkundige op de situatie en omstandigheden van de kwetsbare en hulpbehoevende medemens" (Gastmans 1996: 155). Zorgzaamheid als betrokkenheid behelst een bepaalde manier van omgaan met de patiënt. Dat uit zich in de manier van aanspreken, aanraken en zich gedragen tegenover de patiënt.

'Deze houding is door niemand op een bewuste wijze te 'acteren', ze is ook moeilijk technisch beheersbaar of aanleerbaar, juist omdat ze gekenmerkt wordt door een hoge graad van spontaniteit. Het zijn gebaren die te menselijk zijin om slechts tot routine te verworden." (Gastmans i996: 155). Recentelijk heeft de zoektocht van Gastmans naar de morele dimensie van zorg geleid tot een publicatie waarin de morele dimensie van verplegen wordt geëxpliciteerd. Gastmans e.a. (2000) combineren een historische analyse van het concept zorg met de analyse van Bishop en Scudder en het filosofische werk van Martin Buber en Emmanuel Levinas om een opvatting van ethische zorgverlening te formuleren, waarin het welzijn van patiënten in de meest ruime zin van het woord, namelijk op lichamelijk, psychisch, sociaal en levensbeschouwelijk vlak, het uitgangspunt is:

"... de zorgpraktijk dient geinspireerd te zijn door de menselijk bekommernis om het welzijn van de patiënt. Dit welzijn wordt des temeer bevorderd naarmate de patiënt als persoon in als zijn dimensies erkend wordt. Op de primaire gerichtheid op het welzijn van de patiënt is de verpleegkunde als het ware gefundeerd. Dat impliceert dat de verpleegkundige praktijk op zich ethisch van aard is." (p. 36).

Uit het voorafgaande moge duidelijk zijn dat verpleegkundige deugdethici niet afzonderlijke handelingsvraagstukken centraal stellen, zoals verpleegkundige principe-ethici dat doen, maar dat zij de ethische dimensie van het zorgproces als geheel willen expliciteren, evenals de daarmee verbonden deugden van goede zorgverlening. Vanuit conceptuele, filosofische en historische studies naar de morele dimensie van verpleegkundig zorgverlenen, 
wordt verplegen benoemd als inherent ethisch van aard omdat ze gericht is op het welzijn (welbevinden, menswaardigheid) van patiënten als 'hele' mens.

De relatie tussen verpleegkundige en patiënt krijgt in het kader van verpleegkundige deugdethiek een bijzondere rol toebedeeld. Goede zorg is inherent verbonden met deze relatie. Deze relatie heeft in het kader van verpleegkundige deugdethiek een andere betekenis dan de verpleegkundige-patiënt relatie waarover in de principe-ethiek gesproken wordt. Daar wordt deze relatie vooral gezien als een soort contract tussen twee mensen die op basis van gelijkwaardigheid afspraken maken, waaraan beiden zich moeten houden. Het is een relatie waarin emotionele betrokkenheid, empathie of inlevingsvermogen nauwelijks een rol speelt. In het kader van verpleegkundige deugdethiek wordt de verpleegkundige-patiënt relatie opgevat als een persoonlijke relatie, waarin emoties een rol spelen. Betrokkenheid, inlevingsvermogen, empathie, aandacht, en dergelijke, zijn deugden die verbonden zijn met het persoonlijke en het emotionele. Wanneer in het kader van deugdethiek gesproken wordt over goede zorg die is ingebed in de verpleegkundige-patiënt relatie, dan is het deze persoonlijke relatie waarnaar wordt gewezen. Goede zorg kan alleen vanuit een persoonlijke relatie tussen verpleegkundige en patiënt gestalte krijgen.

\section{Morele problematiek}

Morele problematiek krijgt in een verpleegkundige deugdethiek een specifieke vorm. Op de eerste plaats richt deugdethiek zich op zorgsituaties waarin existentiële aspecten in het geding zijn. De problemen waarmee verpleegkundigen te maken krijgen bevinden zich op het vlak van het dagelijks omgaan met “... lijden, lichamelijkheid, privacy, emoties, waarheid, gezag, afhankelijkheid" (Gastmans 1993/4: 160). Deugdethici gaan ervan uit dat patiënten die ziek zijn in hun bestaan worden bedreigd. Wat betekent het voor deze mens om ziek te zijn en afhankelijk van zorg? Hoe om te gaan met angst, paniek, hoop, wanhoop, verdriet of onzekerheid? In een deugdethiek worden morele kwesties in verband gebracht met mensen die zich geremd voelen in hun zelfontplooiing. Morele kwesties gaan over betekenisgeving en zingeving.

Op de tweede plaats gaat het in een deugdethiek om problematiek waarin verpleegkundigen of andere zorgverleners een zodanige houding ten opzichte van patiënten aannemen, dat deze zich als mens al dan niet gerespecteerd voelen. 'Bejegening' is een belangrijk thema binnen deze ethiek. Veronderstelling is dat patiënten in hun menswaardigheid worden aangetast, wanneer ze niet als mens benaderd en gezien worden. Wanneer verpleegkundigen niet in staat zijn een persoonlijke relatie met een patiënt aan te gaan of te onderhouden, wordt dit gezien als een morele kwestie. Wanneer verpleeg- 
kundigen niet over de juiste relationele deugden beschikken of deze niet op de juiste wijze inzetten in de zorg, leidt dit tot morele problematiek.

In het kader van verpleegkundige principe-ethiek is veel aandacht voor situaties waarin autonomie van patiënten in het geding is. In het kader van de verpleegkundige deugdethiek gaat het in eerste instantie niet om dergelijke kwesties. Deugdethici zijn gericht op problematiek die patiënten ervaren omdat ze in hun persoonlijke integriteit worden aangetast of niet als mens worden bejegend. Tegelijkertijd worden kwesties waarin eigen keuzes van patiënten in het geding zijn, als problematisch erkend. Om eigen wensen van patiënten te kunnen respecteren krijgt de verpleegkundige-patiënt relatie in de verpleegkundige deugdethiek opnieuw een belangrijke rol toebedeeld. Hierbij wordt ervan uitgegaan dat alleen binnen de relatie tussen verpleegkundige en patiënt inzicht verkregen kan worden in de manier waarop patienten kunnen worden ondersteund in het maken van eigen keuzes. ${ }^{26}$ Wat patiënten zelf willen en hoe ze gesteund kunnen worden om hun eigen wensen te verwezenlijken, kan alleen binnen een relatie tot uitdrukking komen. De vraag of een principe als 'respect voor autonomie' daarbij van betekenis veranderd, wordt in het kader van de verpleegkundige deugdethiek niet gethematiseerd. Dat is wel het geval in feministische zorgethische literatuur, die in de volgende paragraaf aan de orde komt.

In deze paragraaf is de verpleegkundige deugdethiek aan de orde geweest, die al vanaf Florence Nightingale binnen de verpleging wordt besproken, maar die ten tijde van de principe-ethiek uit zicht is verdwenen. In het kader van kritiek op de principe-ethiek, wordt opnieuw aandacht besteed aan deugdethiek binnen de verpleging. Vanuit filosofische en historische studies van het concept 'goede zorg', wordt geconstateerd dat in de praktijk van verplegen goede zorg inherent samenhangt met de verpleegkundige-patiënt relatie en dat relationele deugden binnen deze praktijken kunnen worden geleerd. Verpleegkundigen moeten een deugdzame houding ontwikkelen, die hen in staat stelt het welzijn van patiënten of hun menswaardig bestaan te bevorderen. In de deugdethiek hebben morele kwesties van doen met situaties waarin mensen in hun persoonlijke integriteit worden aangetast of niet als mens worden bejegend. Deze kwesties worden zichtbaar binnen de verpleegkundige-patiënt relatie en moeten ook hierbinnen worden gehanteerd.

\section{ZORGETHIEK ALS PRAKTIJKETHIEK}

In deze paragraaf wordt een derde stroming besproken die binnen de verpleegkundig ethische literatuur te onderscheiden is, namelijk de zorgethiek. Duidelijk zal worden dat zorgethiek op twee manieren verschilt van 
de verpleegkundige deugdethiek die in de vorige paragraaf aan de orde is gekomen. ${ }^{.7}$ In het kader van de verpleegkundige deugdethiek worden conceptuele, historische en filosofische studies verricht om inzicht te krijgen in de vraag wat goede zorg betekent en welke deugden van goede zorgverlening daarmee samenhangen. In de zorgethiek wordt voorgesteld om concrete zorgactiviteiten te bestuderen, om te achterhalen wat binnen een specifieke zorgpraktijk op een bepaald moment goede zorg betekent. Op de tweede plaats verschilt zorgethiek van de deugdethiek binnen de verpleging, omdat zorg niet alleen in verband wordt gebracht met (relationele) deugden. ${ }^{28}$ Zorgen wordt in navolging van Fisher en Tronto (1991) opgevat als een proces dat erop gericht is de wereld te herstellen of in stand te houden, zodat mensen er zo goed mogelijk in kunnen leven. In deze paragraaf wordt dit zorgethisch perspectief besproken. Daarbij wordt gebruik gemaakt van auteurs die de zorgethiek als ethisch perspectief voor de verpleging uitwerken. ${ }^{29}$ Omdat deze stroming binnen de verpleging nog in de kinderschoenen staat, zal bij het bespreken van de zorgethiek in deze paragraaf ook literatuur van buiten de verpleging betrokken worden. Er wordt gebruik gemaakt van feministische literatuur waarin zorgethiek als nieuw perspectief op ethiek wordt uitgewerkt. ${ }^{3 \circ}$ Daarnaast wordt gebruik gemaakt van de uitwerking van zorgethiek binnen de gezondheidsethiek."

\section{Morele problematiek}

In deze paragraaf wordt belicht welke kwesties de aandacht krijgen in de zorgethiek. Daarbij wordt ook ingegaan op de status en rol van ethische principes, omdat deze in het kader van de verpleegkundige principe-ethiek - die nog steeds dominant is binnen de verpleging - een centrale rol krijgen toebedeelt. Tot slot komt de betekenis van het concept 'autonomie' aan de orde.

\section{Typen morele kwesties}

In zorgethische literatuur zijn vier typen morele kwesties te onderscheiden. Op de eerste plaats worden kwesties besproken die van doen hebben met het in stand houden en herstellen van de wereld, zodat mensen er zo goed mogelijk in kunnen leven. Op de tweede plaats besteden zorgethici aandacht aan kwesties waarin het verdelen en toedelen van verantwoordelijkheden aan de orde is. Op de derde plaats wordt in zorgethische literatuur ingegaan op de vraag wat zorgverleners zelf nodig hebben, om goede zorg te kunnen geven. En op de vierde plaats worden gangbare ethische kwesties waarin principes botsen besproken, vanuit zorgethisch perspectief.

Ethiek gaat volgens zorgethici over de vraag welke zorg mensen van anderen nodig hebben om hun wereld leefbaar te maken. 'Zorgen voor elkaar', is 
het uitgangspunt om de verhoudingen tussen mensen te regelen. In de verpleegkundige principe-ethiek wordt ervan uitgegaan dat individuele vrijheid het uitgangspunt is van een goed leven en derhalve dient als aanknopingspunt om de manier waarop mensen met elkaar omgaan te reguleren. Daarom wordt in de principe-ethiek ook zo veel nadruk gelegd op het zelfbeschikkingsrecht. Alleen in bijzondere omstandigheden kan daarvan worden afgeweken. Situaties waarin mensen niet over hun eigen leven kunnen beschikken, moeten zo veel mogelijk vermeden worden. Wanneer ze desalniettemin ontstaan, moet zo snel mogelijk toegewerkt worden naar een situatie waarin mensen wel weer zelf invulling kunnen geven aan hun eigen leven. Individuele vrijheid is de leidraad voor het ethisch denken in het kader van de principe-ethiek. Zorgethici verzetten zich daartegen. Volgens hen moet niet de vraag wat mensen willen uitgangspunt zijn van ons ethisch denken, maar de vraag wat mensen van anderen nodig hebben om hun wereld als leefbaar te ervaren.

Vanuit de opvatting dat mensen anderen nodig hebben om hun wereld leefbaar te maken, hanteren zorgethici een andere mensbeeld dan de principe-ethiek. In de principe-ethiek staat het autonome individu centraal dat in staat is in vrijheid over het eigen leven te beschikken. Zorgethici bekritiseren deze liberale opvatting van mens-zijn. ${ }^{32} \mathrm{Zij}$ stellen daar een ander mensbeeld tegenover dat zichtbaar wordt wanneer de aandacht wordt gevestigd op mensen in zorgrelaties. Dan wordt zichtbaar dat mensen anderen nodig hebben om betekenis te geven aan hun bestaan. Op zich is het niet verwonderlijk dat dit mensbeeld naar voren komt bij het bestuderen van zorgrelaties. Wat wel bijzonder is, is dat deze verbondenheid wordt benoemd als centraal kenmerk van ons mens-zijn. Afhankelijkheid is dat wat mensen als mens kenmerkt en moet derhalve het uitgangspunt zijn om gezamelijk vorm te geven aan een leefbare wereld. Mensen zijn geen volledig autonome wezens die geheel los van anderen invulling kunnen geven aan het eigen leven. Relationele verbondenheid kenmerkt ons mens-zijn. Daarom moet niet het bevorderen van zelfbeschikking als leidraad gebruikt worden om de verhoudingen tussen mensen te regelen. Waar het om gaat is de vraag welke zorg mensen van anderen nodig hebben om hun wereld leefbaar te maken. Om de kwaliteit van persoonlijke levens te bevorderen, evenals de kwaliteit van het samenleven, moeten mensen voor elkaar zorgen. Dat wil zeggen bezorgd zijn om de ander, betrokken raken bij elkaar, verantwoordelijkheid voelen iets aan de situatie van iemand anders te veranderen om de situatie leefbaar te maken.

Ethiek heeft in het kader van zorgethiek te maken met de manier waarop wij mensen voor elkaar kunnen zorgen. Op de eerste plaats willen zorgethici daarom kwesties bespreken die samenhangen met de vraag 'welke zorg hebben mensen nodig om hun wereld in stand te houden of te herstellen, zodat zij er zo goed 
mogelijk in kunnen leven?'. Met opzet staat er 'zo goed mogelijk', omdat zorgethici er van uitgaan dat het er om gaat, een situatie te creëren waarin mensen zo goed mogelijk kunnen leven. Het doel van zorg is niet gericht op de meest ideale situatie, maar op een werkbare en leefbare situatie. Een situatie waarmee een ieder die daarbij betrokken is in ieder geval kan leven. Zorgethici benadrukken ook de tijdelijkheid van het doel van zorg, omdat mensen steeds anders kunnen zijn en omdat de situaties en netwerken van relaties waarin ze zich bevinden kunnen veranderen. Mensen kunnen steeds andere zorg nodig hebben, om hun wereld als leefbaar te ervaren.

Zorgethiek formuleert morele problematiek in termen van zorgbehoeften. Welke zorg hebben specifieke mensen van anderen nodig om het bestaan zo leefbaar mogelijk te maken? Omdat ethiek in verband wordt gebracht met zorgen voor een ander, heeft morele problematiek ook te maken met kwesties van relationaliteit en verbondenheid. Wat is de kwaliteit van menselijke relaties? Hoe kunnen mensen goed voor elkaar zorgen? Door de vraag centraal te stellen 'hoe wij goed voor elkaar kunnen zorgen, zodat we zo goed mogelijk in onze wereld kunnen leven', vraagt zorgethieknet als de verpleegkundige deugdethiek - erkenning voor bronnen van morele problematiek die buiten de categorieën van morele principes vallen." Niet de vraag hoe vrijheid en onafhankelijkheid kan worden gewaarborgd is het uitgangspunt van ethiek, maar de vraag hoe om te gaan met zorgbehoeften van anderen, zoals die bijvoorbeeld samenhangen met de afhankelijkheid, kwetsbaarheid en de eindigheid van het menselijke bestaan. Ethische kwesties hebben volgens zorgethici niet zozeer de vorm van "how to balance the principles of self-determination and sanctity of life or even how to determine the risk/benefit ration of continued treatment", zoals in een principeethiek het geval is, maar eerder de vorm van "how I should respond to Mike's (patient) needs, hopes, and dreams" (Parker I990:36). Morele problematiek heeft volgens zorgethici te maken met bijvoorbeeld het bevorderen van zelfverwerkelijking en zelfontplooiing, het bieden van comfort en een goede en vredige dood, wederzijdse erkenning, het behouden of uitbreiden van de mogelijkheden van een persoon, de kwaliteit van relaties met familie of de acceptatie van een individu binnen een gemeenschap. ${ }^{\text {i4 }}$

Op de tweede plaats wordt in de zorgethiek morele problematiek gesitueerd in het verdelen van verantwoordelijkheden. 'Verantwoordelijkheid' is een centrale term in de zorgethiek. In de verpleegkundige principe-ethiek staat de kwaliteit van ethisch denken en redeneren centraal. Zorgvuldig hanteren van morele problematiek wordt daarom in verband gebracht met de term 'rechtvaardigheid'. Deze heeft de betekenis van objectief en onpartijdig oordelen over morele kwesties, om willekeur, eigen belangen en specifieke voorkeuren zo veel mogelijk uit te sluiten. Zorgethiek zet daar de term 'verantwoordelijk- 
heid' tegenover. Deze term verwijst naar de concrete activiteit van het zorgen, die er op gericht is om morele kwesties zorgvuldig te hanteren. In de zorgethiek wordt de focus verschoven. Niet het denken en redeneren staat centraal, maar de activiteit van het zorgen. De term 'zorgen' verwijst naar het verantwoordelijk hanteren van morele problematiek. Hoe kan ik op verantwoordelijke wijze reageren op zorgbehoeften van anderen? Wat kan ik doen orn de situatie voor een ander zo leefbaar mogelijk te maken?

In zorgethisch perspectief gaat het niet alleen om de vraag wat het betekent om op verantwoordelijke wijze zorg voor anderen op te nemen. Het gaat ook om de vraag hoe verantwoordelijkheden tussen zorgverlener en zorgontvanger zijn verdeeld. Wat moet de kwaliteit van een zorgrelatie zijn om het geven en ontvangen van zorg mogelijk te maken? In dat kader worden ook kwesties van 'vertrouwen' op de agenda gezet. Om verantwoordelijkheid over te dragen, is vertrouwen nodig. Degene die iets aan een ander toevertrouwt dat voor hem of haar van waarde is, moet ervan op aan kunnen dat diegene er goed voor zorgt. ${ }^{35}$

Daarnaast besteden zorgethici ook aandacht aan de vraag hoe verantwoordelijkheden zijn verdeeld tussen zorgverleners onderling. ${ }^{36}$ Door te bestuderen wie verantwoordelijk is voor de inhoud van de zorg en wie de zorg moet uitvoeren, kunnen specifieke verantwoordelijkheidsproblemen aan het licht gebracht worden. ${ }^{37}$ Bijvoorbeeld dat diegene die bepaalt hoe de zorg eruit moet zien en degene die de daadwerkelijke zorg verleent vaak niet een en dezelfde persoon zijn. Of de vraag waarom personen die de verantwoordelijkheid toebedeeld krijgen het lichamelijk zorgwerk te verrichten, vaak tot een specifieke groep in onze samenleving behoren. Waarom zijn sommige groepen in onze samenleving beter in staat voor zichzelf te zorgen dan anderen?

Zorgethiek thematiseert het verdelen en toedelen van verantwoordelijkheid ook binnen de institutionele of maatschappelijke context waarin zorg wordt verleend. ${ }^{38}$ Bijvoorbeeld door in te gaan op de vraag of zorgverleners een samenleving nodig hebben die zorg waardeert om voor een ander te kunnen zorgen. Op maatschappelijk niveau kunnen grotere sociale verbanden kritisch bevraagd worden. Zijn er sociale structuren die de sociale afstand tussen groepen vergroten en het gevoel van verantwoordelijkheid om voor elkaar te zorgen doen afnemen?

Een derde onderwerp dat in het kader van zorgethiek de aandacht krijgt, heeft te maken met de vraag wat zorgverleners zelf nodig hebben, om voor een ander te kunnen zorgen. Wat betekent het voor zorgverleners zelf om tegemoet te komen aan zorgbehoeften van anderen? Kan een verantwoordelijkheid tot zorgen begrensd worden? Wanneer verwordt zorg voor een ander tot zelfopoffering? Wanneer gaat betrokkenheid te ver? Hoe kan ongegaan worden met botsingen tussen de eigen verlangens en de verantwoordelijk- 
heid om voor anderen te zorgen? In de zorgethiek is ook aandacht voor de vraag welke ondersteuning een zorgverlener zelf nodig heeft om goede zorg te kunnen geven. Welke zorgnetwerken zijn nodig om voor anderen te kunnen zorgen? Welke, maatschappelijke of institutionele waardering hebben zorgverleners nodig om zorg te kunnen geven?

Een laatste type problematiek dat in zorgethische literatuur wordt besproken heeft te maken met meer gangbare ethische kwesties. Zorgethici willen 'oude' kwesties, die doorgaans in termen van principes worden behandeld, vanuit een ander perspectief bespreken. In de zorgethiek worden morele kwesties verbonden met noden van mensen die de leefbaarheid van hun wereld in de weg staan. Zorgethici herformuleren deze noden in termen van zorgbehoeften. Welke zorg hebben mensen nodig om de wereld leefbaar te maken? Zowel morele problematiek, als ook het hanteren ervan, wordt geformuleerd in termen van 'zorgen'. Dat wil niet zeggen dat zorgethiek alleen van toepassing wil zijn voor praktijken die we normaal gesproken onder de noemer van 'zorgen' brengen, zoals verpleegkundige zorgverlening. Dat is uitdrukkelijk niet het geval. Zorgethiek wil ook van toepassing zijn op praktijken die binnen de principe-ethiek de aandacht krijgen. Dus ook allerlei politieke en maatschappelijke kwesties willen zorgethici vanuit hun perspectief herformuleren en bestuderen. Ze brengen hun ethisch perspectief in verband met zorgen, omdat ze veronderstellen dat waarden en vaardigheden die van belang zijn om voor elkaar te zorgen ook bruikbaar zijn voor het expliciteren en hanteren van morele problematiek. Zorgethici herformuleren morele problematiek daarom niet in termen van principes, maar in termen van zorgbehoeften. Welke zorg hebben mensen nodig om hun wereld in stand te houden of te herstellen, zodat ze er zo goed mogelijk in kunnen leven?

Vanuit hun perspectief van zorg overdenken zorgethici gangbare ethische kwesties waarin principes botsen. 'Hoe kunnen middelen rechtvaardig verdeeld worden?', is volgens zorgethici bijvoorbeeld een relevante ethische kwestie. Een dergelijke vraag moet volgens hen niet onderzocht worden in termen van rechten en plichten. Waar het om gaat is welke zorg mensen nodig hebben om hun wereld leefbaar te maken, gezien vanuit de persoon die ze zijn en de specifieke omstandigheden waarin ze zich bevinden. Alleen wanneer zichtbaar is wat specifieke mensen in hun bijzondere omstandigheden nodig hebben om hun wereld leefbaar te maken, wordt het mogelijk een antwoord te geven op de vraag wat 'rechtvaardig' betekent. Het kan rechtvaardig zijn sommige mensen meer te geven dan anderen, gezien vanuit de positie waarin ze zich bevinden of vanuit de persoon die ze zijn. Vanuit zorgethiek hebben mensen geen rechten omdat ze mens zijn, zoals in een principe-ethiek wordt gesteld, maar hebben mensen zaken nodig om hun wereld leefbaar te maken, omdat ze unieke mensen zijn die zich in bijzondere 
omstandigheden bevinden. Zorgethiek stelt voor gangbare ethische kwesties opnieuw te bestuderen vanuit een perspectief van zorg en verantwoordelijkheid.

\section{Status en rol van principes}

Bij het expliciteren van morele problematick wijzen zorgethici de exclusieve rol af, die ethische principes krijgen toebedeeld in de principe-ethiek. Vooral, zoals Parker (1990) dat formuleert, als ze op zeer strikte wijze worden gehanteerd en toegepast.

"Rather than serving as tools to facilitate ethical decision, principles can become a pretense to defend one's own biases and to pass them off as absolutes. Rather than stimulating creative thinking and moral imagination, principles can become tyrannical gods to which we bow down." (Parker 1990: 36).

Zoals in paragraaf I van dit hoofdstuk is besproken, is in de verpleegkundige principe-ethiek primair aandacht voor kwesties waarin ethische principes botsen. Zorgethici wijzen deze exclusieve aandacht af en stellen voor om morele kwesties te formuleren in termen van zorgbehoeften van mensen die samenhangen met het in stand houden of herstellen van de wereld zodat mensen er zo goed mogelijk in kunnen leven. Door deze verschuiving in perspictief komt aandacht voor kwesties als angst, pijn of lijden, in het kader van ethiek. Net als de verpleegkundige deugdethiek, stelt zorgethiek dat exclusieve aandacht voor principes onvoldoende ruimte laat om dergelijke kwesties aan de orde te stellen. Daamaast stellen zorgethici dat wanneer kwesties aan de orde zijn die op het eerste oog vooral met principes te maken hebben, de aandacht daartoe niet moet worden beperkt. Ook dan moet oog zijn voor andere aspecten van de situatie. Wanneer het bijvoorbeeld gaat om een afhankelijkheidspositie waarin mensen zich bevinden, dan speelt hierin niet alleen de vraag hoe ver bemoeienis met het leven van anderen mag gaan. 'Welke zorg heeft iemand nodig om het bestaan leefbaar te maken?', is de centrale vraag van zorgethiek. Hoe kan iemand vorm geven aan het eigen leven, in situaties van afhankelijkheid? Een discussie louter over zelfbeschikkingsrecht schiet dan tekort. Sterker nog, volgens zorgethici kan teveel nadruk op het principe van zelfbeschikkingsrecht leiden tot wat Tronto (I993) 'geprivilegieerde onverantwoordelijkheid' noemt. 'Hij wil het toch zelf, als rechtvalardiging om iemand aan zijn lot over te laten. Morele kwesties vertalen in termen van principes, laat te weinig ruimte voor het op betrokken en verantwoordelijke wijze hanteren van morele problematiek. Ook wanneer principes in het geding zijn, moet de centrale vraag zijn hoe de wereld voor een ander zo leefbaar mogelijk gemaakt kan worden. Of en hoe principes daarbij een rol spelen, kan verschillend zijn. 
Zorgethici verzetten zich ook tegen de manier waarop principes worden toegepast. Zij hebben kritiek op de neutrale en onpartijdige houding die een verpleegkundige principe-ethiek voorstelt. $\mathrm{Zij}$ stellen daar persoonlijke betrokkenheid en praktische kennis van de situatie tegenover. Problematiek met betrekking tot bijvoorbeeld de vraag hoe ver bemoeienis met het leven van anderen mag gaan, vraagt volgens zorgethici niet om een rationele analyse van botsende principes, maar om "personal involvement, moral struggle, and emotional investment" (Cooper r991: 27). Abstraheren naar principes is in dergelijke situaties ongewenst, omdat daardoor details van de situatie uit het oog worden verloren, terwijl het juist moet gaan om de individuele patiënt. in zijn of haar specifieke omstandigheden. ${ }^{39}$ Het bespreken van ethische problemen, ook wanneer het gaat over de vraag hoe ver bemoeienis met het leven van een ander mag gaan, moet ingebed blijven binnen de concrete context omdat alleen hierin zicht verkregen kan worden op de vraag wat iemand nodig heeft om zijn of haar wereld zo leefbaar mogelijk te maken.

\section{Morele kwesties rondom autonomie}

Autonomie krijgt in de zorgethiek vorm rond de vraag hoe kunnen mensen in concrete omstandigheden met hun eigen kwetsbaarheid en afhankelijkheid omgaan op een manier die bij hen past en hun wereld zo leefbaar mogelijk maakt?'. Autonomie krijgt niet de betekenis van 'recht om zelf in vrijheid te beslissen', maar van 'authentiek zijn'.$^{\circ}$ Het gaat om het ontwikkelen en behouden van een eigen identiteit en integriteit" om richting te kunnen geven aan het eigen kwetsbare en van anderen afhankelijke bestaan. In zorgethisch perspectief zijn autonome keuzes, keuzes die passen bij het eigen leven en de eigen identiteit en integriteit. Om dergelijke keuzes te maken moeten mensen in staat zijn zichzelf kritisch te bevragen over wie ze zijn of willen zijn. Het is een procedure waarin iemand zichzelf de vraag stelt of hij of zij de verantwoordelijkheid voor een bepaalde actie kan nemen en tegelijkertijd respect voor zichzelf kan behouden. ${ }^{* 2}$ Of dat iemand zichzelf afvraagt of hij of zij het kan verdragen de persoon te zijn die een bepaalde actie heeft ondernomen. ${ }^{43}$

Zorgethiek verbindt autonomie opgevat als authenticiteit op twee manieren aan relaties met anderen. Op de eerste plaats wordt gesteld dat voor het vormgeven van een eigen identiteit en integriteit, relaties met anderen nodig zijn. Het ontwikkelen van opvattingen van het zelf en een goed leven, lokaliseert een zorgethiek binnen relaties met anderen. Met een opvatting van autonomie als 'relationele authenticiteit' wordt afstand genomen van het gangbare autonomie ideaal binnen de ethiek, waarin mensen worden voorgesteld als wezens die "in volledige onafhankelijkheid hun grenzen verkennen en uit zijn op het actualiseren van hun onbegrensde mogelijkheden" 
(Verkerk I996: I6). Mensen zijn juist afhankelijk van elkaar voor het vorm. geven van een eigen identiteit en integriteit en opvattingen van een goed leven. Een eigen identiteit wordt in een zorgethiek, in tegenstelling tot de verpleegkundige principe-ethiek en verpleegkundige deugdethiek, niet opgevat als iets ontologisch, in die zin dat ze gegeven is en dat mensen ermee ter wereld komen. Een eigen identiteit is niet iets dat gevonden kan worden door alle gesocialiseerde lagen eraf te pellen, maar is een dynamisch en gesocialiseerde identiteit. ${ }^{44}$ "Het zelf wordt niet opgevat als een ding, maar als de protagonist van een levensverhaal, dat allerlei ambiguiteiten en onverwachte wendingen kan vertonen" (Sevenhuijsen, 1996, p. 74).

"Zorgethiek gaat uit van een beeld van een processueel zelf, een zelf dat altijd in de maak is. Het gaat dan om een proces waarin morele identiteit wordt ontwikkeld en steeds weer herzien. Het construeren van morele identiteit is in die zin ... iets dat we doen en maken binnen menselijke relaties ..." (Sevenhuijsen 1996: 74).

Parker (1990) spreekt in dit verband over de 'co-construction of meaning'. Volgens deze auteur ligt de identiteit van een patiënt en diens wensen en verlangens niet vast, maar zijn die voortdurend in ontwikkeling in veranderende situaties. Verpleegkundigen moeten samen met patiënten betekenis geven aan de situatie en zullen daarom mede bepalen hoe patiënten betekenis geven aan hun leven.

Op de tweede plaats verbindt zorgethiek autonomie aan relaties met anderen, omdat wordt verondersteld dat anderen nodig zijn voor het aanleren, ontwikkelen en uitvoeren van vaardigheden die gebruikt worden om autonomie, in de zin van authenticiteit te realiseren. In het kader van verpleegkundige principe-ethiek hebben mensen vaardigheden nodig om uitdrukking te geven aan hun autonomie, opgevat als zelfbeschikkingsrecht. Het gaat vooral om het ontwikkelen en gebruiken van vaardigheden die te maken hebben met het begrijpen en kunnen plaatsen van informatie binnen het eigen leven. Wensen en verlangens van patiënten spelen daarbij een rol. Deze moeten worden geëxpliciteerd, zodat keuzes die mensen maken daaraan kunnen worden aangepast. Wensen en verlangens van patiënten worden daarbij opgevat als specifieke uitdrukkingen van hun wil en in die zin als uitdrukkingen van hun autonomie als zelfbeschikking. Autonomie opgevat als authenticiteit legt de nadruk op vaardigheden die nodig zijn om een eigen identiteit en integriteit te ontwikkelen en om waarden, doelen, wensen en verlangens te formuleren en herformuleren, om zo richting te kunnen geven aan het eigen leven. Meyers (I987) benoemt dergelijke vaardigheden als 'autonomy competence'. Dat zijn vaardigheden zoals "... introspective skills, communicative skills, reasoning skills, imaginative skills, and volitional skills" (Meyers I992: I26). "Autonomy competence' is volgens Meyers nodig voor het ontwikkelen van een zelfbeeld, 
opvattingen van een goed leven en het kritisch kunnen reflecteren hierop. Door zulke vaardigheden uit te voeren komen mensen in contact met wie ze zijn, wat belangrijk voor ze is, hoe ze zich willen ontwikkelen of veranderen en hoe ze uitdrukking kunnen geven aan hun wensen, doelen, belangen en waarden. Anderen zijn nodig voor het ontwikkelen van 'autonomy competence'.

Autonomie kan vanuit een zorgethisch perspectief beter omschreven worden als authentiek worden dan als authentiek zijn, omdat authenticiteit van mensen niet alleen in relatie tot anderen ontwikkeld wordt, maar ook omdat authenticiteit voortdurend om reflectie en aanpassing vraagt, omdat omstandigheden waarin mensen zich bevinden en hun netwerk van relaties veranderlijk is. In een zorgethisch perspectief wordt ervan uitgegaan dat hoe mensen zijn niet vastligt, maar voortdurend kan verschillen.

In deze paragraaf zijn typen morele kwesties besproken, die in zorgethische literatuur te onderscheiden zijn. In de zorgethiek is aandacht voor kwesties die buiten de categorieën van principes vallen en die te maken hebben met het zo leefbaar mogelijk maken van de wereld van mensen. Daarnaast worden in de zorgethiek morele kwesties besproken in termen van verantwoordelijkheden. Hoe kan aan deze verantwoordelijkheid voor anderen vorm gegeven worden? Hoe zijn verantwoordelijkheden tussen betrokkenen bij morele kwesties verdeeld? Ook is in het kader van zorgethiek aandacht voor de vraag wat zorgverleners zelf nodig hebben om voor anderen te kunnen zorgen. Het laatste type morele kwesties dat in zorgethische literatuur aan de orde komt, zijn handelingsvraagstukken waarin principes botsen. Deze worden op een andere manier besproken dan in het kader van de verpleegkundige principe-ethiek het geval is, namelijk vanuit hun eigen perspectief van betrokkenheid en verantwoordelijkheid. Naast het beschrijven van de verschillende typen morele kwesties die in de zorgethiek aan de orde komen, is in het eerste deel van deze paragraaf ook beschreven dat zorgethici de exclusieve rol van ethische principes afwijzen. En tot slot is besproken welke betekenis 'respect voor autonomie' krijgt in het kader van zorgethiek, namelijk die van 'relationele autonomie als authenticiteit'.

\section{Hanteren van morele problematiek}

In de principe-ethiek wordt volgens zorgethici te veel nadruk gelegd op rationele vermogens van mensen om morele problematiek te hanteren. Rechtvaardig oordelen heeft van doen met abstract, logisch, neutraal en onpartijdig denken en redeneren. 
".... an ideology of moral knowledge: the belief that moral knowledge is not only justified but also acquired exclusively or most importantly through rational reflection.... the belief that individual reflection, if it conforms to cannons of rationality, guarantees the truth of ones moral judgments." (Calhoun 1988: 457).

Dat mensen in staat zijn tot rationele reflectie wordt gezien als een garantie voor zowel de correctheid van het formuleren van deze algemene principes, als ook een garantie voor een correcte toepassing ervan. Verondersteld wordt dat door moreel oordelen te verbinden aan rationeel denken, de kans op een rechtvaardig oordeel zo groot mogelijk wordt.

Zorgethiek wil zich onderscheiden van een dergelijk perspectief. Zoals in de vorige paragraaf is besproken, is volgens zorgethici niet rechtvaardig denken maar verantwoordelijk handelen het centrale kenmerk van ethiek. Niet objectief, onpartijdig en neutraal redeneren als belangrijkste middel om morele problematiek te hanteren, maar op een betrokken en verantwoordelijke manier handelen, waarbij denken en doen samengaan. In het kader van zorgethiek wordt morele problematiek daarom beschreven in termen van zorgbehoeften. Zorgen voor anderen is niet mogelijk door alleen te denken, maar er moet ook gehandeld worden. Hanteren van morele problematiek wordt in de zorgethiek daarom omschreven als een zorgproces. In deze paragraaf worden kennis en vaardigheden beschreven die samenhangen met het proces van zorgverlenen en dus volgens zorgethici met het hanteren van morele problematiek.

\section{Ethiek is een kwestie van verantwoordelijk handelen}

In het kader van zorgethiek gaat het niet om de vraag 'hoe kunnen wij rechtvaardig oordelen?', maar om de vraag 'hoe kunnen we in specifieke omstandigheder voor elkaar zorgen?'. 'Voor elkaar zorgen' heeft volgens zorgethici te maken met het nemen van en vorm geven aan verantwoordelijkheid voor anderen. Hanteren van morele problematiek is een zorgproces waarvan 'verantwoordelijkheid' de kem is. Volgens zorgethici gaat het in het kader van hanteren van morele problematiek om de vraag 'Hoe kan ik op verantwoordelijke wijze tegemoet komen aan zorgbehoeften van anderen?'. Zorgethici hanteren daarbij geen klassiek ethische definitie van het concept 'verantwoordelijkheid', waarbij het meestal gaat om de vraag onder welke condities iemand verantwoordelijk is voor zijn of haar handelingen. Hierbij wordt veelal verondersteld dat een individu moreel verantwoordelijk kan worden gehouden, wanneer een bepaalde handeling ook geleid heeft tot het te beoordelen gevolg en dat deze handeling in vrijheid is uitgevoerd. Zorgethici hanteren een relationeel ex contextueel concept van verantwoordelijkheid. ${ }^{45} \mathrm{Het}$ 
gaat om de vraag 'waar ben ik verantwoordelijk voor in relatie tot specifieke anderen en hoe kan ik aan deze verantwoordelijkheid gestalte geven?'.

Zorgethici stellen voor om morele problematiek te situeren rondom zorgbehoeften van mensen en de vraag hoe hieraan op een verantwoordelijke manier tegemoet gekomen kan worden. Wat is een verantwoordelijke reactie op gesitueerde zorgbehoeften van een kwetsbare en afhankelijke ander? In zorgethiek gaat het om vragen als: hoe kan ik het best mijn zorg-verantwoordelijkheid gestalte geven ? ${ }^{* i ;}$; hoe kan ik verantwoorde zorg verlenen?"; hoe kan ik deze situatie het beste kennen?

Het op verantwoordelijke wijze tegemoet komen aan zorgbehoeften van anderen wordt in het kader van de zorgethiek ook in verband gebracht met de vraag wat de kwaliteit van een dergelijke relatie moet zijn. Het behouden van goede relaties is een belangrijke voorwaarde voor het tegemoet komen aan zorgbehoeften van anderen. Dit betekent dat in dit perspectief ook eerder oog zal zijn voor vragen omtrent betrokkenheid en bejegening of hoe een goede zorgrelatie tot stand kan worden gebracht. Het gaat bijvoorbeeld om de vraag hoe vertrouwen en zorg met elkaar samenhangen of welke vertrouwensrelaties moreel deugdelijk zijn en welke niet. ${ }^{50}$ Er wordt gesproken over het belang van vertrouwensrelaties en de maakbaarheid en breekbaarheid ervan."

Zorgethici overdenken dergelijke vragen die samenhangen met verantwoordelijk handelen ten aanzien van morele problematiek. In het vervolg van deze paragraaf wordt besproken, wat het volgens zorgethici betekent om morele problematiek op een verantwoordelijke manier te hanteren.

\section{Praktische en betrokken kennis van concrete zorgbehoeften}

Verantwoord handelen betekent volgens zorgethici dat de ander gezien en begrepen moet worden, als een specifiek persoon met specifieke behoeften. Volgens zorgethici moeten anderen - zoals Flanagan and Jackson dat formuleren - 'thickly' gezien worden:

"Whereas justice as fairness involves seeing others thinly, as worthy of respect purely by virtue of common humanity, morally good caring requires, seeing others thickly, as constituted by their particular human face, their particular psychological and social self' (Flanagan \& Jackson I993: 623).

In een principe-ethiek wordt een specifieke opvatting van de mens gehanteerd. Mensen worden 'thinly' in beeld gebracht, door alle sociale, psychologische en biologische verschillen eraf te halen. Een persoon is iemand die ons respect verdient en bepaalde rechten heeft puur omdat deze mens is. En hoewel een dergelijke opvatting sympathiek is, wijst een zorgethiek deze af als aanknopingspunt voor ethische reflectie. In het perspectief van zorgethiek betekent respect hebben voor anderen, de ander 'thickly' zien. Dat wil 
zeggen, iemand zien als een persoon met een eigen identiteit en een eigen psychologisch en sociaal zelf. Deze specifieke ander moet in beeld gebracht worden en uitgangspunt zijn van ethische reflectie. ${ }^{52}$

Zorgethici pleiten er daarom voor om bij het hanteren van morele proble. matiek, kennis te verzamelen over de specifieke situatie van een persoon en daarbij oog te hebben voor details en verschillen. Dat betekent niet een roep voor een onderdompeling in veel verschillende details van de situatie of een meer gedetailleerde weergave van de feiten. Het is een pleidooi voor een bepaalde manier van moreel denken en handelen, namelijk een contextuele manier." Morele kennis en moreel redeneren is niet gericht op het belichten van algemeenheden, zoals bijvoorbeeld het identificeren van de morele principes, "but to the vagaries of circumstances that configure our lives as human beings" (Carse 1998: 64). Omgaan met zorgbehoeften van specifieke, gesitueerde en kwetsbare anderen, vraagt om kennis die verzameld is vanuit een 'insiders positie', omdat het gaat om kennis over het bijzondere en het individuele. ${ }^{5 a}$ Dergelijke kennis hoeft niet zonder meer toepasbaar te zijn op andere situaties, maar moet openstaan voor wat anders is en verandert. Waerness (1990) zet deze kennis tegenover wetenschappelijke kennis die gaat over wat constant blijft en voorspelbaar is en die wordt opgedaan door vanuit een outsiders positie te zoeken naar wetmatigheden die algemeen geldig en toepasbaar zijn.

Opvattingen over morele kennis en moreel redeneren verschuiven in een zorgethisch perspectief van kennis over principes en het geven van "simple rule-like directives" (Carse 1998: 159) voor de toepassing ervan, naar "a view on which the task is more like a complex process of interpretation, articulation, and fine-grained, imaginative, discriminating perception" (Carse 1998 : I59). Kennis verzamelen is een proces dat zich voltrekt binnen het zorgend handelen zelf. Het is een proces van interpretatie en articulatie, waarbij er met name aandacht is voor het bijzondere van mensen en de situaties waarin ze zich hevinden. Als morele actor betrokken zijn in een dergelijk proces, betekent afgestemd zijn op een grote hoeveelheid relevante factoren. Een dergelijk proces wordt in een zorgethisch perspectief eerder opgevat als een:

"rich and detailed narrative interpretation of a case than as the application of a contained rule or algorithm, fonnulated directly and in general terms as a prescription tor action" (Carse r998: 159).

Zorgethic: ${ }^{3 \xi}$ binnen de verpleging besteden veel aandacht aan de waarde van praktische kennis. Wat verpleegkundigen nodig hebben is kennis over hoe patiënten zich voelen en welke betekenis het ziek zijn voor hen heeft. Volgens bijvoorbeeld Crowden (1994) gaat het erom in het kader van het hanteren van morele problematiek, kennis te verzamelen die gericht is op concrete en veranderlijke dingen. Praktisch inzicht is niet uit op het vaststel- 
len wan algemene samenhangen, maar op het verkrijgen van inzicht in wat in een concreet geval het beste past bij de omstandigheden. Het gaat om praktisch inzicht in een situatie, zodat bepaald kan worden wat op een specifiek tijdstip de juiste wijze wan handelen is. Een dergelijk inzicht kan alleen verworven worden in het handelen zelf door ervaring en oefening en vraagt om inzet van de gehele persoon. Ook Patricia Benner ${ }^{56}$ beschrijft relevante kennis voor zorgverlenen als een vorm van 'praktische kennis'. Benner heeft intensief kwalitatief onderzoek verricht naar de vraag wat expertise in de verpleging inhoudt. Benner omschrinft praktische kennis als 'embodied know how', een worm van gesitueerde kennis, die gebaseerd is op 'engaged practical reasoning', een betrokken en praktische manier van redeneren. Benner verwijst naar 'tacit knowing' (Polanyi 1958), 'knowing in action' (Schön 1983 ) en 'knowing the particular patient' (Tanner et.al. 9 $^{8} 83$ ). Deze vormen van kennis verwijzen allen naar eenzelfde fenomeen. Het is praktische kennis die in het zorgend handelen zelf verzameld wordt en die het mogelijk makk dat verpleegkundigen zien wat patiënten nodig hebben en daarop kumen reageren. Bemer noemt dit: "knowledge that sets up the possibility for the nurse to recognize and respond in this particular situation' (Benner 1996:6). Het is kennis en inzicht die stoelt op een doorleefd begrip van de 'gewone' praktijk, openheid naar de huidige specifieke situatie en diepgaande betrokkenheid.

In het voorafgaande is gesteld dat voor zorgethici, praktische kennis van de specifieke situatie van mensen het uitgangspunt is van ethisch denken en handelen. Het gaat om kennis van concrete en specifieke mensen, met al hun bijzonderheid en verschillen. Deze kennis kan alleen verzameld worden in het zorgend handelen zelf. Relevante kennis van een specifieke persoon in diens situatie kan niet verzameld worden door als een buitenstaander naar een situatie te kijken, maar vraagt om een 'insiderspositie' dic alleen verworven kan worden door betrokken te raken bij een zorgproces en er verantwoordelijkheid voor te nemen. Alleen in het handelen zelf wordt duidelijk welke kennis relevant is en welke niet. Verantwoord hanteren van morele problematiek is een proces van zorgverlenen dat erop gericht is zorgbehoeften van een ander, vanuit een betrokken positie in detail te leren kennen.

\section{Epistemologische deugden}

In de zorgethiek wordt bij het bespreken van de rol van praktische kennis, het concept "epistemologische deugden" gebruikt. Met deze term wil men binnen de zorgethiek benadrukken dat, bij het verzamelen van kennis die relevant is om zorgbehoeften te leren kennen, een deugdzame houding van de zorgverlener nodig is. 
De term 'epistemologie' verwijst naar opvattingen over 'goede kennisverwerving'. Goede kennisverwerving wordt in de verpleegkundige principeethiek opgevat als het objectief op een rijtje zetten van de feiten. Verzamelen van kennis is een zaak van cognitie, waarbij emoties geen rol spelen. Door objectief te kijken en te luisteren en door de eigen waarden zo veel mogelijk buiten te sluiten, wordt verondersteld dat de situatie van een patiënt objectief gekend kan worden. Juist door van kennisverwerving een cognitieve aangelegenheid te maken, waarbij emoties van degene die de kennis verwerft en diens belangen geen rol mogen spelen, wordt getracht een objectieve weergave van de werkelijkheid te geven en een rechtvaardig en onpartijdig oordeel mogelijk te maken.

Zorgethici als Code (1990, 1995) hanteren een andere opvattingen van goede kennisverwerving. Code introduceert met haar concept 'epistemologische deugden' een specifieke opvatting van kennisverwerving in het domein van ethiek. Met de term 'epistemologische deugd' wil zij aangeven dat kennisverwerving niet alleen een cognitieve aangelegenheid moet zijn, maar dat daarbij persoonlijke betrokkenheid van de zorgverlener vereist is. Het is niet mogelijk zorgbehoeften van een ander te leren kennen, zonder daar als persoon bij betrokken te raken. Er moet een bereidheid zijn de ander persoonlijk te leren kennen. Epistemologische deugden worden in het kader van zorgethiek daarom in verband gebracht met deugden als: geduld, inlevingsvermogen, aandacht, nabijheid, compassie, oog voor verschil en details, verbondenheid, affectiviteit, verantwoordelijkheid, communicatie, intuitie, liefde, relationaliteit. Dergelijke deugden zijn nodig om de ander te leren kennen en worden daarom benoemd als deugden voor goede kennisverwerving.

\section{Zorg als proces}

Joan Tronto (1983) wordt algemeen als de belangrijkste vertegenwoordiger van de zorgethiek als praktijkethiek gezien. $\mathrm{Zij}$ heeft verantwoord hanteren van norele problematiek als zorgproces verder uitgewerkt. Hierbij besteedt ze aandacht aan het leren kennen van zorgbehoeften, zoals Code doet, als ook aan vaardigheden die nodig zijn om adequaat en betekenisvol op zorgbehoeften te reageren. Zoals in het eerste deel van deze paragraaf reeds aan de orde is gekomen, omschrijven Fisher en Tronto dit proces als volgt:

"On the most general level, we suggest that caring be viewed as a species activ-

ity that includes everything that we do to maintain, continue, and repair our "world' so that we can live in it as well as possible." (Fisher \& Tronto, 1991: 40). Zorg is volgens deze auteurs alles wat we doen om ons leven in stand te houden, te continueren en herstellen, zodat we zo goed mogelijk in onze wereld kunnen leven. Vervolgens werkt Tronto deze opvatting van zorg uit in een proces van vier fasen, die volgens haar onlosmakelijk met elkaar samenhangen 
maar analytisch te onderscheiden zijn. Zij duidt dit zorgproces aan als een moreel proces, door bij ieder fase bijbehorende deugden van zorgverlening te formuleren.

De eerste fase die Tronto aan het zorgproces onderscheidt is caring about. Dit betekent 'oog hebben voor' en wil zeggen dat bij een zorgverlener een besef ontstaat dat in een situatie sprake is van noden van een ander, die de leefbaarheid van de wereld in de weg staan. Wanneer mensen deze gevoeligheid voor de noden van een ander niet bezitten, wordt de vraag om zorg niet herkend en waargenomen. Een ethische houding die nodig is om de behoeften aan zorg van een ander te kunnen zien is attentivenes, dat wil zeggen aandachtige betrokkenheid. Een voorbeeld hierbij is dat iemand ziet dat een oncologiepatiënt in een isolement raakt, omdat deze door zijn of haar omgeving wordt gemeden.

De volgende fase heet taking care of en verwijst naar 'ervoor zorgen dat' of 'zorg dragen voor'. In deze fase wordt tot handelen besloten. Er wordt erkend dat een ander behoeften heeft die, wanneer er niet voor wordt gezorgd en in die zin de behoeften niet worden vervuld, het bestaan niet of minder leefbaar is. Zorgen dat er iets aan de noden van een ander wordt gedaan, betekent niet dat men ook zelf het concrete werk doet. Het betekent dat verantwoordelijkheid wordt gevoeld voor het op gang brengen van een zorgend antwoord op een zorgvraag die in fase $\mathrm{I}$ is onderkend. De ethische vaardigheid die bij deze fase hoort is responsibility. Dit wil zeggen dat iemand zich verantwoordelijk opstelt. Een voorbeeld hierbij is het op gang brengen van lotgenotencontact voor oncologiepatiënten die in een isolement dreigen te raken.

Care giving staat voor de activiteit van het zorgen, waarbij zorgen de betekenis heeft van het daadwerkelijk werk verzetten om het leven van een ander in stand te houden of te herstellen. Deze fase betreft het praktische handelen van een zorggever. De hiermee verbonden morele kwaliteit is competence oftewel gekwalificeerd zijn, vakbekwaam zijn.

Care receiving tot slot, verwijst naar het ontvangen van zorg. Wanneer er sprake is van pogingen om aan zorgbehoeften van een ander te voldoen ${ }_{n} \mathrm{zal}$ ook deze ander actief bij de zorg betrokken moeten zijn. De zorgontvanger geeft aan of ontvangen zorg goed is en aansluit bij zijn of haar behoeften. Dit perspectief van de zorgontvanger maakt het volgens Tronto mogelijk handelen van zorgverleners te bereflecteren. Zorg voor een ander (als verantwoord hanteren van morele problematiek) moet erop gericht zijn de wereld voor deze ander zo leefbaar mogelijk te maken. Wanneer een zorgontvanger aangeeft dat zorg niet passend is, wil dat niet zeggen dat de zorgverlener zonder meer met deze uiting van zorgontvanger moet meegaan, maar begint het zorgproces weer opnieuw. Van zorgontvangers wordt verwacht dat ze responsief zijn. Responsivenes houdt in dat een zorgontvanger bereid moet zijn om 
zijn of haar eigen zorgbehoeften goed te interpreteren en zorgantwoorden te bereflecteren. Dit vraagt om een open houding ten aanzien van de geboden zorg. Een patiënt moet bereid zijn aan te geven of de zorg die een verpleegkundige geeft aansluit bij zijn of haar behoeften. Tegelijkertijd is de deugd van 'responsiveness' van toepassing op de zorgverleners. Zij moeten openstaan voor reacties van zorgvragers en bereid zijn het eigen handelen ter discussie te stellen en kritisch te overdenken.

Tronto geeft met haar vier fasen van zorg aan hoe zij denkt dat het hanteren van morele kwesties die samenhangen met het in stand houden of herstellen van de wereld, op een ethisch verantwoorde manier kan gebeuren. Uit deze omschrijving van zorg als proces kunnen kennis en vaardigheden worden gedestilleerd die zij relevant vindt voor het hanteren van ethische problematiek. Het zijn vaardigheden die erop gericht zijn de zorgontvanger 'thickly' te zien met al zijn specifieke kenmerken, eigenschappen, relaties, wensen, verlangens en noden die daaruit voortkomen Het gaat om epistemologische deugden van een aandachtige, betrokken en verantwoordelijke manier van kennisverwerving en om de competentie om adequaat en betekenisvol te reageren op zorgvragen.

\section{Reflectie en dialoog}

Tot besluit van deze paragraaf wordt een laatste type ethische vaardigheden belicht dat volgens zorgethici van belang is bij het verantwoord hanteren van morele kwesties. Door onder andere Sevenhuijsen (1996) en Widdershoven (r999a) worden de ethische vaardigheden van dialoog en reflectie naar voren geschoven.

Zorgethiek is een contextuele ethiek. Dat wil zeggen dat ze veel waarde toekent aan de manieren waarop betrokkenen zelf morele problematiek expliciteren en hanteren. Zorgethici gaan er van uit dat het niet mogelijk is om in algemene termen te formuleren wat mensen nodig hebben om het bestaan draaglijker te maken. Daarom is het van belang betrokkenen zelf aan het woord te laten en morele kwesties vanuit hun perspectief aan de orde te stellen. Sommige zorgethici, zoals Sevenhuijsen (1996), gaan nog een stapje verder. Zij stelt dat er geen algemeen gezichtspunt is buiten een praktijk waarmee handelen van betrokkenen kan worden beoordeeld. Alleen in het handelen zelf wordt duidelijk wat de doelen zijn die worden nagestreefd en dus ook wat als goede zorg geldt. Om ervoor te zorgen dat handelen daarmee niet volledig afhankelijk wordt van betrokkenen, benadrukt zij het belang van communicatie, reflectie en dialoog binnen een praktijk. Binnen moreel overleg kunnen volgens Sevenhuijsen oordelen over zorg gegeven worden. Gesitueerde communicatie en dialoog, gericht op consensus, neemt de plaats in van regels voor besluitvorming en algemeen geldende principes of daarvan 
afgeleide waarden, normen rechten en plichten. Betrokkenen moeten zich volgens Sevenhuijsen steeds opnieuw afvragen welke aspecten van goede zorg de moeite waard zijn om de status te geven van gemeenschappelijkheid, ook al gaat het om wankele compromissen of om tijdelijke vormen van consensus. Aan de ethische vaardigheden die door Tronto zijn geformuleerd, voegen auteurs als Sevenhuijsen (1993) en Widdershoven (1999) daarom de deugden van communicatie, reflectie en dialoog toe. Betrokkenen bij morele problematiek moeten in voortdurende interactie met elkaar bepalen of er verantwoord wordt gehandeld.

In het voorafgaande zijn de handvatten besproken die zorgethiek geeft.om. morele kwesties op een verantwoorde manier te hanteren. Zorgethiek geeft deze aanwijzingen in termen van 'zorgen'. Waarden en vaardigheden die gewoonlijk verbonden worden met goede zorg, zoals betrokkenheid, verantwoordelijkheid en inlevingsvermogen, worden door zorgethici naar voren geschoven als hulpmiddelen om morele kwesties te formuleren en te hanteren. Tegemoet komen aan morele problematiek vatten zorgethici op als een zorgproces. Verantwoord hanteren van morele problematiek is een proces dat erop gericht is mensen in hun eigen specifieke en bijzondere context te leren kennen om een zorgvuldig en verantwoordelijk antwoord te kunnen geven op hun noden.

\section{ConClusie}

In dit hoofdstuk zijn verschillende stromingen binnen de verpleegkundige ethiek besproken om een ethisch perspectief te destilleren, dat bruikbaar is om morele ervaringen van verpleegkundigen te belichten. Doel van dit boek is licht te werpen op morele ervaringen van verpleegkundigen met dagelijkse zorgverlening, vanuit de veronderstelling dat hierdoor inzicht verkregen kan worden in hun frustraties die ertoe bijdragen dat zij het vak de rug toe keren. Morele ervaringen worden in dit boek in verband gebracht met opvattingen van verpleegkundigen van goede zorg, de wijze waarop ze deze proberen te geven en problemen die ze daar bij tegenkomen.

In dit hoofdstuk is verpleegkundige principe-ethiek besproken. In een dergelijk perspectief worden morele kwesties bezien in het licht van conflicterende principes. Dat heeft als consequentie dat bepaalde problemen meer prominent onder de aandacht worden gebracht dan anderen. Met name die. problematische kwesties in de zorgverlening kunnen worden belicht, die zich lenen voor een vertaling in termen van principes. In dit perspectief is daarom weinig ruimte om andere morele kwesties in beeld te brengen, die samenhangen met het geven van goede zorg. Verpleegkundige principe-ethiek. 
belicht niet het gehele proces van zorgverlenen. Ze belichten situaties waarin zich conflicten voordoen, bijvoorbeeld wanneer het gaat om een rechtvaardige verdeling van middelen, om het respecteren van autonomie van mensen of om de vraag hoe goed te doen en niet te schaden.

De zorgethiek zoekt net als de verpleegkundige deugdethiek naar een breder perspectief op ethiek, om ook morele kwesties die samenhangen met het zorgproces te kunnen bespreken. Verpleegkundige deugdethiek zoekt daarbij naar opvattingen van goede zorg in historische en filosofische bespiegelingen over verplegen. Uit deze studies komt de verpleegkundige-patiënt als centraal element van goede zorg naar voren. Binnen de persoonlijke relatie tussen verpleegkundige en patiënt, kan het welzijn van patiënten worden bevorderd of de menswaardigheid van het bestaan worden vergroot. Verpleegkundige deugdethiek formuleert algemene opvattingen van goede zorg en daarmee samenhangende deugden van goede zorgverlening, als uitgangspunt voor ethische reflectie. Zorgethiek daarentegen gaat ervan uit dat opvattingen van goede zorg verbonden zijn met specifieke zorgpraktijken en pleit ervoor om morele ervaringen van betrokkenen als uitgangspunt te nemen voor ethische reflectie. Dat is de belangrijkste reden dat in dit onderzoek voor zorgethiek wordt gekozen om morele ervaringen van verpleegkundigen met dagelijks zorgverlenen inzichtelijk te maken. In het volgende hoofdstuk wordt zorgethiek uitgewerkt als perspectief voor het empirische onderzoek, om morele ervaringen van verpleegkundigen op de werkvloer inzichtelijk te maken. 


\section{KWALITATIEF ONDERZOEK: OPZET EN AANPAK}

Dit proefschrift heeft tot doel om morele ervaringen van verpleegkundigen zichtbaar te maken, die samenhangen met het geven van dagelijkse zorg. In dit hoofdstuk wordt de opzet en aanpak van het empirische onderzoek naar morele ervaringen van verpleegkundigen besproken. De keuze om het theoretisch kader van zorgethiek hiervoor te gebruiken wordt beargumenteerd, evenals de keuze dit onderzoek uit te voeren op een hematologie oncologie afdeling van een academisch ziekenhuis. Bovendien worden methoden van dataverzameling, -analyse en verslaglegging besproken.

\section{THEORETISCH KADER EN VRAAGSTELLINGEN}

Om inzicht te krijgen in de vraag wat verpleegkundigen onder goede zorg verstaan, hoe ze deze proberen te geven en welke problemen ze daarbij tegenkomen, wordt gebruik gemaakt van verpleegkundige ethiek. Zoals in het vorige hoofdstuk is beschreven worden binnen verpleegkundige ethiek met name drie perspectieven besproken, namelijk: verpleegkundige principeethiek, verpleegkundige deugdethiek en zorgethiek. Daarbij is betoogd dat een ethisch perspectief niet neutraal is. Dit perspectief schrijft namelijk voor wat een moreel probleem is en hoe dit moet worden gehanteerd. Een ethisch perspectief maakt daarmee sommige aspecten van verpleegkundige zorgverlening zichtbaar en andere niet. Het empirische onderzoek waarvan in dit boek verslag wordt gedaan, wil morele ervaringen van verpleegkundigen met dagelijkse zorgverlening zichtbaar maken. Een keuze om daarvoor zorgethiek te gebruiken ligt dan voor de hand.

\section{Zorgethiek als theoretisch kader}

Om morele ervaringen van verpleegkundigen met dagelijkse zorgverlening zichtbaar te maken worden een aantal uitgangspunten van de zorgethiek gebruikt."

Het eerste uitgangspunt van de zorgethiek, dat in dit onderzoek wordt gevolgd, is het voorstel om ervaringen en activiteiten van betrokkenen bij het zorgproces centraal te stellen. Volgens zorgethici moeten betrokkenen zelfaan het woord gelaten worden en moet bestudeerd worden hoe zij werkzame en 
leefbare oplossingen vinden, om inzicht te kriigen in de aard, omvang en reikwijdte van morele kwesties. Deze basisgedachte van de zorgethiek sluit aan bij de uitgangspunten van dit onderzoek. Zoals in hoofdstuk $\mathrm{r}$ is besproken is het doel van deze studie om morele ervaringen van verpleegkundigen met dagelijkse zorgverlening inzichtelijk te maken. Aanleiding daartoe was de veronderstelling dat gebrek aan ruimte om hun opvattingen van goede zorg waar te maken, een rol spelen bij het ontstaan van frustraties, stress en burn-out. Het pleidooi om betrokkenen zelf aan het woord te laten om inzicht te krijgen in morele kwesties, sluit aan bij de doelstelling en aanleiding van dit onderzoek.

Een tweede uitgangspunt van de zorgethiek, dat in dit onderzoek wordt gehanteerd, is het pleidooi om ook de bredere context waarin zorg wordt gegeven te betrekken bij het inzichtelijk maken van morele kwesties, zoals financiële middelen, wet en regelgeving, personele bezetting, en dergelijke. Inzicht in deze context is van belang, omdat deze mede bepalend is voor de gedaante die morele kwesties aannemen en voor de ruimte die zorgverleners in hun zorgend handelen ervaren om hun opvattingen over goede zorg in de praktijk te brengen. ${ }^{2}$ Zoals in hoofdstuk I is besproken, wordt in dit onderzoek ervan uitgegaan dat de context ertoe bijdraagt dat verpleegkundigen niet die zorg kunnen geven die ze zouden willen geven. Verpleegkundigen kunnen gefrustreerd raken, omdat volgens hen de ruimte en middelen ontbreken om zorg aan zorgvragers te geven die zij als goed ervaren. Daarom wordt in het empirisch onderzoek de aanwijzing van zorgethiek opgevolgd, om de context te betrekken bij het inzichtelijk maken van morele ervaringen van verpleegkundigen.

De derde aanwijzing van zorgethiek, die wordt opgevolgd in het empirische onderzoek, is het voorstel om het zorgproces centraal te stellen. Zorgethiek stelt voor het morele niet zo zeer te zoeken in de vraag of en hoe ethische principes een rol spelen of te bestuderen welke deugden verpleegkundigen nodig hebben om goede zorg te geven. Zorgethici stellen voor om het zorgproces centraal te stellen om inzicht te krijgen in morele problematiek. Door deze aanwijzing van zorgethiek op te volgen kunnen kwesties in beeld gebracht worden die verpleegkundigen tegenkomen wanneer ze in de dagelijkse zorg proberen goede zorg te geven aan patiënten.

\section{Vraagstellingen voor het empirische onderzoek}

De centrale vraagstellingen van dit onderzoek hebben betrekking op: opvattingen van verpleegkundigen over goede zorg; de vraag hoe ze deze in de dagelijkse zorg proberen te geven; en de problemen die ze daarbij tegenkomen. Op basis van bovenstaande aanwijzingen van zorgethiek worden deze vragen verder geconcretiseerd. 
Om het zorgproces centraal te kunnen stellen bij het inzichtelijk maken. van morele ervaringen van verpleegkundigen, is de volgende vraag geformuleerd:

Aan welke zorgbehoeften die samenhangen met het in stand houden of herstellen van de wereld van patiënten proberen verpleegkundigen tegemoet te komen, zodat zij er zo goed mogelijk in kunnen leven?

In het denken en handelen van verpleegkundigen wordt bekeken aan welke zorgbehoeften van patiënten zij aandacht besteden. Door de aandacht te vestigen op 'zorgbehoeften' kan worden aangesloten bij dagelijkse activiteiten om morele ervaringen van verpleegkundigen zichtbaar te maken. Welke zorgbehoeften signaleren verpleegkundigen bij patiënten die een 'zo goed mogelijk leven' in de weg staan?

Om inzicht te krijgen in morele ervaringen van verpleegkundigen met dagelijkse zorgverlening, wordt daarnaast bestudeerd hoe zij proberen aan dergelijke zorgbehoeften van patiënten tegemoet komen:

Hoe proberen verpleegkundigen tegemoet te komen aan zorgbehoeften die samenhangen met het in stand houden of herstellen van de wereld van patiënten, zodat zij er zo goed mogelijk in kunnen leven?

Om ook de context bij de zoektocht naar morele ervaringen van verpleegkundigen te kunnen betrekken, wordt bestudeerd in welke situaties zij problemen, moeilijkheden en belemmeringen ervaren bij het tegemoet komen aan zorgbehoeften van patiënten:

In welke situaties komen verpleegkundigen moeilijkheden, problemen en belemmeringen tegen, juist omdat ze erop gericht zijn patiënten te ondersteunen bij het in stand houden of herstellen van hun wereld zodat zij ir zo goed mogelijk in kunnen leven?

In het empirische onderzoek wordt antwoord gezocht op bovenstaande vragen, vanuit de veronderstelling dat daarmee morele ervaringen van verpleegkundigen met dagelijkse zorgverlening inzichtelijk gemaakt kunnen worden. In paragraaf 3 van dit hoofdstuk wordt aangegeven hoe verpleegkundigen, met behulp van kwalitatieve onderzoeksmethoden, daarbij zelf zo veel mogelijk aan het woord gelaten kunnen worden. Maar eerst wordt in de volgende paragraaf aangegeven waarom er gekozen is voor een hematologie oncologie afdeling om bovengenoemde vragen te bestuderen. 
HeMATOLOGIE ONCOLOGIE VEPPLEGING

De kwalitatieve studie is uitgevoerd op een hematologie oncologie afdeling. Dit is een afdeling waar patiënten behandeld en verpleegd worden die intensieve chemokuren krijgen, vaak aangevuld met een BeenMergTransplantatie (BMT). Hoewel dit daardoor een afdeling lijkt waar vooral technische zorg verleend wordt of patiënten met name psychisch begeleid worden, is dat niet het geval. Op deze afdeling, zo zal ik in deze paragraaf laten zien, worden allerlei zorgende handelingen verricht die ook binnen andere contexten voor verple. ging en verzorging worden uitgevoerd. Daarom, zo wordt beargumenteerd, is deze afdeling geschikt om dit onderzoek uit te voeren.

Voor een hematologie oncologie afdeling is gekozen, omdat er een breed cala aan '

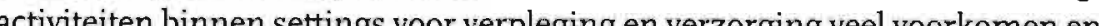
verbonden zijn met dagelijke zorgén en verong merbonden zijh met dagelikse zorg. Een gangbare en dagelijks veelvoorkomende zorgactiviteit is bijvoorbeld lichamelijke verzorging van patienten. Dit komt welhaast in elke setting voor verpleging en verzorging voor. Verpleegkundigen ondersteunen patienten bij het wassen, aankleden, uit bed komen, eten en drinken. Een andere gangbare zorgactiviteit heeft te maken met de psychisch begeleiding van patiënten. Verpleegkundigen praten veel met patiënten en hun farrilie over wat het voor hen betekent om ziek te zijn en behandeld te worden. Verpleegkundigen zijn voortdurend bezig met het informeren van patiënten. Niet alleen over de gang van zaken op de afdeling, maar ook over ziekte en behandeling. Verpleegkundigen van een hematologie oncologie afdeling voeren ook allerlei medisch-technische activiteiten uit net als veel verplegenden en verzorgenden in andere settings. Met deze omschrifving van gangare zorgactiviteiten wordt niet gesugereerd dat is beschreven ving van gangbare zor wat het belk zorgen of da daanee all gangbare zorgactiviterten ziln benoemd. Wat hiermee wordt aangegeven is, dat op deze afdeling dagelijks allerlei verzorgende activiteiten worden verricht, die ook binnen andere settings vaak voorkomen. Er zijn twee redenen om voor een afdeling te kiezen waar gangbare zorgactiviteiten worden verricht. Op de eerste plaats, omdat de bevindingen uit dit onderzoek daardoor herkenbaar kunnen zijn voor verplegenden en verzorgenden uit een andere setting. Hematologie oncologie afdeling is weliswaar een specifieke setting die erop gericht is mensen met behulp van intensieve behandelingen van een levensbedreigende ziekte te genezen, waardoor de zorg een wat andere dimensie heeft dan bijvoorbeeld zorg in een verplees. huis, psychiatrie of zorg voor verstandelijk gehandicapten. Echter omdat er dagelijks veel gangbare zorgactiviteiten worden verricht is het mogelik dat de bevindingen uit dit onderzoek toch herkenbar zijn voor verplegenden verzorgenden die in een geheel andere setting werkzaam zijn. Reden om voor hematologie oncologie te kiezen, is om de herkenbaarheid van de bevindingen voor verplegenden en verzorgenden uit andere setting te vergroten. De tweede reden om te kiezen voor een afdeling waar dagelijks allerle gangbare verzorgende activiteiten worden verticht, is dat het daardoor mogelijk wordt een aantal thema's te formuleren waaraan aandacht besteed moe worden, wanneer het gaat om de vraag waarom verpleegkundigen gefrustreerd en gestrest kunnen raken of burn-out oplopen omdat zij niet die zorg kunnen geven die ze zouden willen geven. Onderzoeksbevindingen uit een omgeving waarin vooral medisch-technische handelingen worden verricht of een afdeling waar patiënten louter psychisch begeleid worden zouden minder brikbar zijn om conclusies te trekken ten anzien van morele ervaringen van verpleegkundigen in het algemeen.

Dat wil niet zeggen dat er op een hematologie oncologie afdeling geen Dat wil niet zeggen dat er op een hematologie oneologie afteling geen staken van behandeling, het toedienen van morfine of vragen rondom reanimeerbeleid. Dat is wel het geval. Vooral omdat op deze afdeling patiënten zijn opgenomen voor een levensbedreigende ziekte, waar ze intensieve behandelingen voor krijgen waar ze zich erg ziek door voelen, maar die helaa niet altijd tot genezing leiden. In dit onderzoek is niet alleen gekozen voo een hematologie oncologie afdeling omdat daar veel voorkomende zorgactiviteiten worden verricht, maar ook omdat verwacht wordt dat op een dergelijke afdeling in het oog springende ethische kwesties spelen. Daardoor kan inzichtelijk gemaakt worden dat - ook wanneer zich dergelijke kwesties voordoen - bestudeerd kan worden wat voor verpleegkundigen goede zor betekent. Hoe proberen verpleegkundigen, patienten die om euthanasie heben wereld, zodat ze er $z$ warin paitaties waarin patienten on euthanasie viagen, morfine toegediend krijgen of waarvoor een reanimeerbeleid is afgesproken, helpen verpleegkundigen hen met eten, drinken of ult bed komen, inform, hen ze patenten over ziekte en behandeling of praten met hen over de betekenis die het ziek zijn voo hen heeft en kan daarbij bestudeerd worden wat zij in dergelijke situaties onder goede zorg verstaan, hoe ze deze proberen te geven en tegen welk moeilijkheden, problemen en belemmeringen ze daarbij aanlopen.

\section{Dataverzameling, -ANalyse en VerslaGlegGing}

In de eerste paragraaf is aangegeven dat zorgethici kwalitatieve onderzoeksmethoden propageren om inzicht te krijgen in morele ervaringen van zorg. 
verzorgenden die in een geheel andere setting werkzaam zijn. Reden om voor hematologie oncologie te kiezen, is om de herkenbaarheid van de bevindingen voor verplegenden en verzorgenden uit andere setting te vergroten.

De tweede reden om te kiezen voor een afdeling waar dagelijks allerlei gangbare verzorgende activiteiten worden verricht, is dat het daardoor mogelijk wordt een aantal thema's te formuleren waaraan aandacht besteed moet worden, wanneer het gaat om de vraag waarom verpleegkundigen gefrustreerd en gestrest kunnen raken of burn-out oplopen omdat zij niet die zorg kunnen geven die ze zouden willen geven. Onderzoeksbevindingen uit een omgeving waarin vooral medisch-technische handelingen worden verricht of een afdeling waar patiënten louter psychisch begeleid worden, zouden minder bruikbaar zijn om conclusies te trekken ten aanzien van morele ervaringen van verpleegkundigen in het algemeen.

Dat wil niet zeggen dat er op een hematologie oncologie afdeling geen gangbare ethische kwesties voorkomen, zoals vragen om euthanasie, het staken van behandeling, het toedienen van morfine of vragen rondom reanimeerbeleid. Dat is wel het geval. Vooral omdat op deze afdeling patiënten zijn opgenomen voor een levensbedreigende ziekte, waar ze intensieve behandelingen voor krijgen waar ze zich erg ziek door voelen, maar die helaas niet altijd tot genezing leiden. In dit onderzoek is niet alleen gekozen voor een hematologie oncologie afdeling omdat daar veel voorkomende zorgactiviteiten worden verricht, maar ook omdat verwacht wordt dat op een dergelijke afdeling in het oog springende ethische kwesties spelen. Daardoor kan inzichtelijk gemaakt worden dat - ook wanneer zich dergelijke kwesties voordoen - bestudeerd kan worden wat voor verpleegkundigen goede zorg betekent. Hoe proberen verpleegkundigen, patiënten die om euthanasie hebben gevraagd, te ondersteunen bij het repareren of herstellen van hun wereld, zodat ze er zo goed mogelijk in kunnen leven? Ook in situaties waarin patiënten om euthanasie vragen, morfine toegediend krijgen of waarvoor een reanimeerbeleid is afgesproken, helpen verpleegkundigen hen met eten, drinken of uit bed komen, informeren ze patiënten over ziekte en behandeling of praten met hen over de betekenis die het ziek zijn voor hen heeft en kan daarbij bestudeerd worden wat zij in dergelijke situaties onder goede zorg verstaan, hoe ze deze proberen te geven en tegen welke moeilijkheden, problemen en belemmeringen ze daarbij aanlopen.

\section{Datayerzameling, -ANalyse en Verslaglegging}

In de eerste paragraaf is aangegeven dat zorgethici kwalitatieve onderzoeksmethoden propageren om inzicht te krijgen in morele ervaringen van zorg- 
verleners. Deze opvatting kan met de uitgangspunten van kwalitatief onderzoek worden onderstreept. In kwalitatieve studies wil men het gedrag van mensen begriipen. Daarom moet dit gedrag binnen de eigen sociale en culturele context bestudeerd worden. Kwalitatieve studies propageren daarom zogenoemde open manieren van dataverzameling, zoals participerende observaties al dan niet gecombineerd met formele (semi-gestructureerde) diepteinterviews. Deze onderzoeksmethoden zijn volgens De Lange, Pronk en Smaling (I999) bij uitstek geschikt om interacties tussen patiënten en verpleegkundigen te bestuderen en worden tegenwoordig steeds meer toegepast binnen de verpleging. Het onderzoek waar dit boek verslag van doet, heeft tot doel morele ervaringen van verpleegkundigen in de dagelijkse patiëntenzorg inzichtelijk te maken. Het gaat erom inzicht te krijgen in hún morele opvattingen van goede zorg en in de problemen die zij ervaren juist omdat ze goede zorg willen geven aan patiënten. Zowel vanuit zorgethiek als op basis van de uitgangspunten van kwalitatief onderzoek is in dit onderzoek daarom gekozen voor kwalitatieve onderzoeksmethoden.

\section{Participerende observaties}

Gedurende vijf maanden heb ik in 1996/1997 participerende observatie verricht op een afdeling waar hematologie oncologie patiënten (afdeling IO) verzorgd worden. Daarbij heb ik in totaal zeventig dagen meegelopen met verpleegkundigen van deze afdeling, heb ik vijftig overdrachten op band opgenomen, heb ik alles gelezen dat aanwezig was op de afdeling en relevant leek voor het beantwoorden van de vraagstellingen in dit onderzoek en heb $\mathrm{ik}$ vragen ter verdieping en verheldering gesteld.

Om de periode van participerende observatie gestalte te geven heb ik de identiteit van HBOV-er op snuffelstage aangenomen.' Door in de rol te kruipen van een beginnend verpleegkundig student was het mogelijk als onderzoeker, gekoppeld aan verpleegkundigen, mee te lopen en de dagelijkse gang van zaken te observeren. Door een verpleegkundig uniform aan te trekken en allerlei hand- en spandiensten te verrichten - de verpleegkundige waste de patiënt en ik poetste de infuuspomp - was het mogelijk aanwezig te zijn op een manier die voor verpleegkundigen en patiënten weinig storend was. Ze waren beide overigens op de hoogte van het doel van de participerende observatie, omdat over het observeren van hun interactie aan hen informatie was verstrekt en toestemming was gevraagd. Voor mezelf was deze rol ook het meest acceptabel. Door in mijn aanwezigheid mee te doen aan de zorg, hoe beperkt ook, was het mogelijk me meer vanzelfsprekend in die setting te bewegen zonder me al te overbodig en storend te voelen.

Wanneer verpleegkundigen 's ochtends de rapportage doorlazen en bespraken, was ik daarbij aanwezig. Wanneer om 7.15 uur werd gestart met de 
zorg, haakte ik aan bij een verpleegkundige waaraan ik gevraagd had of ik die dag met hem of haar mocht meelopen, waardoor ik aanwezig kon zijn bij alles wat die verpleegkundige die dag ondernam. 's Ochtends begon de dag met patiënten verzorgen. Hen op bed wassen of onder de douche helpen of hen steun bieden bij het afdrogen en aankleden. Patiënten behulpzaam zijn bij het uit bed komen, in een stoel gaan zitten en weer in bed kruipen. Patiënten werden naar toilet geholpen of op de po-stoel of pan gezet. Verpleegkundigen verrichtten in de ochtend allerlei activiteiten die gericht waren op de lichamelijke verzorging van patiënten. Daarnaast werden bedden opgemaakt, de kamer opgeruimd, ontbijt rondgebracht en medicatie verstrekt. Door met verpleegkundigen mee te lopen, kon ik observeren waaraan zij aandacht besteedden gedurende de dagelijkse verzorging. Ik heb gekeken naar wat ze deden en heb geluisterd naar wat ze daarbij vertelden.

Tijdens het contact tussen verpleegkundige en patiënt in het kader van de dagelijkse lichamelijke verzorging, werd er vaak en veel gepraat. Afhankelijk van de situatie van een patiënt, hoe deze zich fysiek voelde of de stemming waarin hij of zij verkeerde, werd er over van alles en nog wat gepraat. Over gewone dingen, zoals het weer en het eten, maar ook over vragen van patiënten over ziekte en behandeling, hun zorgen en hun angsten. Ik heb geobserveerd dat patiënten vragen stelden aan verpleegkundigen, dat zij met hen overlegden over de informatie die ze van artsen wilden krijgen of dat er werd gesproken over behandelingsmogelijkheden. Ik heb geluisterd naar patiënten die bijvoorbeeld aan verpleegkundigen vroegen wat zij vonden van de gang van zaken rondom behandeling of dat zij aan hen vroegen wat zij zouden doen wanneer ze zich in deze situatie zouden bevinden. Ik heb gehoord dat patiënten en verpleegkundigen spraken over angsten en zorgen van patiënten. Patiënten die zich zorgen maakten over hun partner, de kinderen, hun werk, hun toekomst en de vraag of er wel een toekomst zou zijn. Patiënten uitten hun pijn bij verpleegkundigen. Vertelden hen waar ze last van hadden, waar het pijn deed en waar ze verdrietig over waren. In het contact tussen verpleegkundige en patiënt werd veel gezegd, werd informatie uitgewisseld, werden meningen en gevoelens gedeeld. Bij tal van deze contacten ben ik aanwezig geweest, omdat ik met een verpleegkundige meeliep en op de kamer meehielp. Daardoor kon ik zien en horen waar ze met patiënten over praatten en hoe ze op hun vragen en zorgen reageerden.

Iedere dag om half Io was er verpleegkundige overdracht. Ook hierbij was ik zeventig keer aanwezig. Tijdens de overdracht heb ik geluisterd naar de gesprekken tussen verpleegkundigen onderling, of met artsen wanneer die daar incidenteel bij aanwezig waren. Verpleegkundigen praten met elkaar over de ziektegeschiedenis en het ziekteverloop van elke patiënt. Vragen en problemen werden doorgesproken. Hoe zit deze meneer in zijn vel? Waarom 
zou hij koorts hebben? Wat is uit dat onderzoek naar voren gekomen? Denk je dat zijn vrouw het aankan? Als hij maar geen heimee krijgt. Moeten we niet iets aan zijn pijn doen? Tijdens de overdracht werden alle patiënten uitgebreid doorgesproken, werd informatie uitgewisseld, werden meningen gedeeld, werden afspraken gemaakt ten aanzien van de zorg en werden vragen geformuleerd die door de Unit Leider aan de artsen werden doorgegeven. Bij deze overdrachten was ik aanwezig en kon ik horen waar verpleegkundigen met elkaar over spraken. Waar ze zich druk over maakten. Wat ze belangrijk vonden. Vijftig van deze overdrachten heb ik ook op band opgenomen en geanalyseerd.

Wanneer verpleegkundigen na de overdracht aan het werk gingen, liep ik weer mee met de verpleegkundige waarmee ik dat had afgesproken. In de loop van de dag werden steeds weer activiteiten verricht die te maken hadden met lichamelijke verzorging en werd er met patiënten gepraat. Daarnaast werden ook allerlei technische handelingen verricht. Ik heb bijvoorbeeld geobserveerd hoe verpleegkundigen de tensie meten, infuuslijnen en insteekopeningen verzorgen, chemo's uitrekenenen en aanhangen, wonden verzorgen, injecties toedienen, sondevoeding geven, assisteren bij een beenmergpunctie, bloedprikken, monden sprayen, etc. Daarbij heb ik geobserveerd hoe ze dergelijke handelingen uitvoerden. Waar letten ze op? Hoe praten ze daarover met patiënten? Wat is voor hen al dan niet belangrijk bij het uitvoeren van technische handelingen?

Gedurende de zorg praatten verpleegkundigen veel met patiënten. Zoals reeds is aangegeven speelde zich dat vaak af gedurende de dagelijkse verzorgende activiteiten. Daarnaast waren er echter soms ook momenten dat verpleegkundigen daar echt voor gingen zitten. Zo ben ik bijvoorbeeld aanwezig geweest bij informatiegesprekken, die tijdens en vlak na de opname werden gedaan. Ik heb gesprekken bijgewoond waarin verpleegkundigen patiënten informeerden over een bepaald onderzoek dat hen te wachten stond. Ook heb ik slechtnieuws-gesprekken geobserveerd waarbij artsen, in aanwezigheid van een verpleegkundige, aan patiënten vertelden dat een behandeling niet had aangeslagen. Door bij verschillende gesprekken aanwezig te zijn, kon ik bijvoorbeeld observeren hoe verpleegkundigen dat aanpakten, wat ze vertelden, welke houding ze daarbij aannamen, of en hoe ze ruimte gaven aan patiënten om vragen te stellen of hun gevoelens te uitten.

Door gekoppeld aan een verpleegkundige mee te lopen, kon ik ook allerlei informeel overleg dat plaatsvond observeren. Verpleegkundigen die op de gang met elkaar overlegden over een patiënt, verpleegkundigen die met artsen praatten, verpleegkundigen die door familie werden aangesproken omdat ze vragen hadden of behoefte aan aandacht.

Wanneer ik meeliep met een verpleegkundige ging ik ook mee lunchen en koffiedrinken. Hierdoor was ik aanwezig wanneer verpleegkundigen in- 
formeel met elkaar spraken. Hierbij werd er ook vaak over zorg gesproken en dan met name wat verpleegkundigen van bepaalde situaties dachten of hoe ze zich daarbij voelden. Bij dit informeel contact ben ik aanwezig geweest en heb ik geluisterd en meegepraat over de zorg die ze gaven en problemen en moeilijkheden die ze daarbij ondervonden.

Ook heb ik een aantal avonddiensten meegedraaid. Ik ben met verpleegkundigen meegelopen wanneer zij de avondmaaltijd rondbrachten, met familie praatten die op bezoek waren en patiënten troosten wanneer die verdrietig waren als ze moesten achterblijven wanneer hun partner of kinderen naar huis gingen. 's Avonds kwamen er vaak emoties boven bij patiënten, die bij verpleegkundigen werden geuit. Bij verschillende van die contacten ben ik aanwezig geweest en heb ik kunnen zien hoe verpleegkundigen daarop reageerden.

Zeventig dagen ben ik aanwezig geweest bij alle activiteiten die de verpleegkundigen op een dag verrichtten Ik heb daarbij interacties met patienten kunnen observeren. Ik heb kunnen horen hoe verpleegkundigen spraken met andere verpleegkundigen, artsen of familie. Door dagelijks op de afdeling aanwezig te zijn en met verpleegkundigen mee te lopen kon ik zien, lezen, horen, voelen en ruiken wat het voor hen betekent om te zorgen voor patiënten die voor een levensbedreigende ziekte op een hematologie oncologie afdeling opgenomen zijn en daarvoor allerlei intensieve behandelingen krijgen. Bovendien kon ik daar direct allerlei vragen over stellen, ter verdieping en verheldering.

\section{Noteren van bevindingen}

Gedurende de periode van participerende observatie zijn op verschillende manieren gegevens verzameld en genoteerd. Op de eerste plaats zijn er chronologische verslagen gemaakt van de interacties tussen patiënten en verpleegkundigen, verpleegkundigen en familie, verpleegkundigen en artsen of andere zorgverleners, en verpleegkundigen onderling. Overdag zijn er schriftelijke aantekeningen gemaakt, die aan het eind van de dag of gedurende de dag op de computer zijn uitgewerkt tot chronologische verslagen. Op de tweede plaats zijn er transcripten gemaakt van vijftig verpleegkundige overdrachten die op band waren opgenomen. Deze overdrachten duren gemiddeld een half uur. Op de derde plaats zijn aan het eind van de observatieperiode i 9 formele semi-gestructureerde diepte interviews afgenomen van gemiddeld I, 5 à 2 uur, waarvan transcripten zijn gemaakt (zie bijlage b voor het interviewschema). Op de vierde plaats is schriftelijke informatie uit rapportages, protocollen en dergelijke overgenomen in zoverre dit van belang was voor het beantwoorden van de vraagstellingen. Op deze manier is uit verschillende bronnen gegevens verzameld om antwoord te vinden op de vraagstellingen van dit onderzoek. 


\section{Aanknopingspunten om het morele inzichtelijk te maken}

Doel van dit onderzoek is om inzicht te verkrijgen in morele ervaringen van verpleegkundigen met dagelijkse zorgverlening. Daarvoor is aangehaakt bij een aantal uitgangspunten van zorgethiek. Zoals in paragraaf $\mathrm{r}$ is aangegeven, stellen zorgethici voor het zorgproces centraal te stellen. In dit onderzoek is deze aanwijzing omgezet in de vraag 'Aan welke zorgbehoeften van patiënten komen verpleegkundigen tegemoet die samen hangen met het in stand houden en herstellen van de wereld, zodat patiënten er zo goed mogelijk in kunnen leven?'. Bovendien wordt bestudeerd hoe verpleegkundigen daaraan tegemoet willen komen en in welke situaties ze tegen moeilijkheden, problemen en belemmeringen ze aanlopen. Deze vraagstellingen kunnen nog op verschillende manieren worden ingevuld. In dit onderzoek gaat het echter niet om het economische denken van verpleegkundigen of hun opvattingen over instrumenteel technisch handelen. In dit onderzoek gaat het om hun morele ervaringen. Om daar daadwerkelijk de aandacht op te kunnen vestigen, zijn een aantal aanknopingspunten voor de periode van participerende observatie geformuleerd. Deze hadden tot doel het morele karakter van ervaringen op het spoor te komen.

Op de eerste plaats is daarom de aandacht uitgegaan naar situaties waarin verpleegkundigen met elkaar, met patiënten, met familie, met andere zorgverleners of met mij spraken in termen van 'dat heeft iemand nodig', 'daar heeft iemand behoefte aan', 'dat is voor iemand heel moeilijk', 'het is belangrijk daar aandacht aan te besteden', 'wat ik in ieder geval voor patiënten wil betekenen', 'wat ik belangrijk vind in de zorg', 'wat goed is om te doen'. Wanneer dat soort termen vielen ben ik alert geworden en heb ik gekeken, geluisterd en gevraagd naar de overwegingen die ten grondslag liggen aan dergelijke opmerkingen. Termen als goed, slecht, mogen, onverantwoord, beter, eerlijk, waren voor mij aanknopingspunten om morele ervaringen op het spoor te komen. Bovendien is in het bijzonder aandacht besteed aan momenten waar verpleegkundigen boos of verontwaardigd waren. Ook is de aandacht uitgegaan naar situaties waarin zij hun handelen ten opzichte van anderen gingen rechtvaardigen, verantwoorden of verdedigen. Om morele ervaringen te identificeren is daarnaast bestudeerd tegen welke problemen verpleegkundigen aanlopen, juist omdat ze tegemoet willen komen aan zorgbehoeften van patiënten. Hierbij is gezocht naar onzekerheden, moeilijkheden en belemmeringen die verpleegkundigen ervaren. De aandacht is vooral uitgegaan naar de volgende situaties. Verpleegkundigen die bijvoorbeeld zeiden dat ze iets moeilijk of ongemakkelijk vonden, verpleegkundigen die niet wisten wat ze moesten doen of hierover discussieerden, verpleegkundigen die niet die zorg konden geven die ze zouden willen geven. Bovendien is gezocht naar conflicterende situaties. Bijvoorbeeld wanneer 
verschillende betrokkenen het niet eens konden worden over de vraag wat goed was om te doen op een bepaald moment.

\section{Verslaglegging}

Met behulp van bovenstaande aanknopingspunten zijn gegevens verzameld over morele ervaringen van verpleegkundige. Bij het analyseren van de gegevens is vervolgens gezocht naar ordeningsprincipes om deze morele ervaringen inzichtelijk te kunnen maken en te kunnen duiden op een manier die dicht aansluit bij de ervaringen en belevingswereld van verpleegkundigen. In de empirische hoofdstukken wordt verslag gedaan van morele ervaringen van verpleegkundigen aan de hand van de volgende ordeningsprincipes.

In hoofdstuk 4 is een ordeningsprincipe van 'zorgbehoeften' gekozen om morele ervaringen van verpleegkundigen te bespreken. In dat hoofdstuk wordt beschreven welke zorgbehoeften verpleegkundigen bij patiënten signaleren aan de hand van de volgende indelingscriteria: zorgbehoeften die samenhangen met de intensieve behandelingen die patiënten ondergaan; zorgbehoeften die samenhangen met een opname in het ziekenhuis; en zorgbehoeften die te maken hebben met het hebben van een levensbedreigende ziekte. Binnen deze verschillende categorieën zijn vervolgens subcategorieën onderscheiden om de zorgbehoeften die verpleegkundigen bij patiënten signaleren nader te omschrijven. Hierbij is tevens aangegeven hoe verpleegkundigen proberen aan deze zorgbehoeften van patiënten tegemoet te komen (zie bijlage $\mathrm{C}$ voor een overzicht van zorgbehoeften). Tijdens het proces van gegevensverzameling en -analyse, met betrekking tot het signaleren en tegemoet komen aan zorgbehoeften van patiënten, werd duidelijk dat verpleegkundigen een specifieke betekenis toekennen aan het in stand houden en herstellen van de wereld, zodat patiënten er zo goed mogelijk in kunnen leven. In hoofdstuk 4 wordt geconcludeerd dat dit voor verpleegkundigen van afdeling to betekent dat ze proberen het leven voor patiënten zo draaglijk mogelijk te maken. Ze willen ervoor zorgen dat patiënten zo goed mogelijk door de ziekte, behandeling en verblijf in het ziekenhuis heenkomen.

In hoofdstuk 5 is ervoor gekozen om aan de orde te stellen dat verpleegkundigen werken in en aan onzekerheid. Daar wordt niet mee bedoeld dat verpleegkundigen voortdurend in een impasse verkeren, omdat ze niet weten wat ze moeten doen. De term 'onzekerheid' verwijst ernaar dat de vraag 'wat goed is om te doen voor een patiënt' niet eenduidig te beantwoorden is. Vaak is onduidelijk wat een patiënt nodig heeft om de situatie als draaglijker te ervaren. In hoofdstuk 5 wordt het onzekere karakter van zorg besproken en wordt beschreven hoe verpleegkundigen daarmee omgaan.

In hoofdstuk 6 worden situaties aan de orde gesteld, waarbij verpleegkundigen aangeven dat goede zorg voor patiënten onder spanning staat. Ver- 
pleegkundigen komen namelijk regelmatig situaties tegen, waarin zij het gevoel hebben dat goede zorg onder druk komt. In hoofdstuk 6 worden dergelijke situaties besproken en wordt erop ingegaan hoe verpleegkundigen deze hanteren.

\section{Citaten en situatieschetsen}

Ter ondersteuning van de beschrijving van de resultaten uit de empirische hoofdstukken, is zo veel mogelijk gebruik gemaakt van citaten of situatieschetsen. Zij vormen de ondersteuning van de bevindingen De citaten kunnen afkomstig zijn uit de chronologische verslagen, uit transcripten van overdrachten of uit formele semi-gestructureerde diepte interviews. Deze verschillende bronnen worden als gelijkwaardig gebruikt. Wanneer verpleegkundigen uit informele gesprekken worden geciteerd, dan zijn deze uitspraken direct genoteerd. Voor de leesbaarheid zijn de citaten gecorrigeerd, zonder de inhoud ervan te wijzigen. De situatieschetsen die worden gebruikt, zijn door de onderzoeker geobserveerd en in eigen bewoordingen genoteerd. Wanneer daarin namen gebruikt worden van verpleegkundigen zijn deze fictief.

\section{CONCLUSIE}

In dit hoofdstuk is de opzet en aanpak van het onderzoek naar morele ervaringen van erpleegkundigen met dagelijkse zorgverlening uitgewerkt. Daarbij is gebruik gemaakt van de aanwijzingen van de zorgethiek. De gegevens die zijn verzameld en geanalyseerd worden in de volgende drie empirische hoofdstukken beschreven.

Door te zoeken naar opvattingen van goede zorg van verpleegkundigen, komt - vooral in hoofdstuk 4 - een betrekkelijk rooskleurig en homogeen beeld naar voren van de zorg die verpleegkundigen aan patiënten geven. Hoewel dit beeld in overeenstemming is met de observatie van het denken en handelen van verpleegkundigen, wil dat niet zeggen dat er geen verschillen zijn tussen verpleegkundigen onderling of dat de gegeven zorg altijd aansluit bij specifieke vragen en problemen van patiënten. Variaties en verschillen worden in hoofdstuk 5 en 6 genuanceerder in beeld gebracht. Daar wordt duidelijk dat verpleegkundigen onderling van mening kunnen verschillen over wat goed is om te doen op een bepaald moment of dat verpleegkundigen om uiteenlopende redenen soms ook niet tegemoet komen aan dringende zorgbehoeften van patiënten. De manier waarop opvattingen van verpleegkundigen over goede zorg in hoofdstuk 4 in beeld zijn gebracht, moet daarom ook niet los gezien worden van hoofdstuk 5 en 6 . Ze zijn alleen analytisch te onderscheiden. 


\section{DRAAGLIJKER MAKEN VAN HET BESTAAN}

In dit hoofdstuk worden morele ervaringen van verpleegkundigen besproken aan de hand van de volgende vragen:

Aan welke zorgbehoeften die samenhangen met het in stand houden of herstellen van de wereld van patiënten proberen verpleegkundigen tegemoet te komen, zodat zij er zo goed mogelijk in kunnen leven?

Hoe proberen verpleegkundigen tegemoet te komen aan zorgbehoeften die samenhangen met het in stand houden of herstellen van de wereld van patiënten, zodat zij er zo goed mogelijk in kunnen leven?

Deze vragen zijn onderzocht door middel van kwalitatieve onderzoeksmethoden, waarbij het denken en handelen van verpleegkundigen is bestudeerd. Daarbij heeft de dagelijkse zorg centraal gestaan, zoals bijvoorbeeld aankleden, wassen, eten, drinken, wondverzorging, medicatie verstrekken, familie begeleiden en patiënten psychisch ondersteunen.

$\mathrm{Bij}$ het beschrijven van de morele ervaringen van verpleegkundigen wordt in dit hoofdstuk zo dicht mogelijk aangesloten bij hun ervaringswereld en taalgebruik. Daarom wordt ook veelvuldig gebruik gemaakt van citaten en situatieschetsen. Zorgbehoeften waaraan verpleegkundigen tegemoet komen, zijn in dit hoofdstuk onderscheiden in drie categorieën. In paragraaf I komen behoeften aan zorg aan de orde die samenhangen met intensieve behandelingen die patiënten aan hun lichaam ondergaan. In paragraaf 2 worden zorgbehoeften besproken die te maken hebben met het opgenomen zijn op een afdeling van het ziekenhuis, weg van de vertrouwde omgeving en thuis. In paragraaf 3 worden zorgbehoeften besproken die samenhangen met een confrontatie met een ziekte die levensbedreigend is en het bestaan aantast. In bijlage $\mathrm{C}$ wordt een overzicht gegeven van zorgbehoeften die in dit hoofdstuk worden besproken.

In dit hoofdstuk worden morele ervaringen van verpleegkundigen niet in verband gebracht met ethische perspectieven. Dat wordt in hoofdstuk 7 gedaan. Daar worden morele ervaringen van verpleegkundigen besproken in het licht van ethische theorievorming. In dit hoofdstuk komt aan de orde 
welke zorgbehoeften verpleegkundigen bij patiënten signaleren en hoe ze daaraan tegemoet proberen te komen.

\section{Behandeling van eEn ziek lichaAm}

In deze paragraaf worden zorgbehoeften van patiënten besproken die samenhangen met intensieve en ingrijpende behandelingen die ze aan hun lichaam ondergaan. Eerst komt aan de orde waarom deze behandelingen zeer intensief en ingrijpend zijn voor patiënten. Vervolgens worden twee typen van zorgbehoeften besproken die daarmee samenhangen. Patiënten worden geconfronteerd met fysieke pijn en lijden en hebben - in die omstandigheden - zorg van verpleegkundigen nodig om zo goed als mogelijk is te leven. Bovendien kunnen patiënten zich overrompeld voelen door de behandelingen en onderzoeken die ze krijgen en daarom zorg van verpleegkundigen nodig hebben.

\section{Ingrijpende behandelingen en onderzoeken}

Patiënten van afdeling to zijn opgenomen voor een oncologische aandoening, zoals de ziekte van Kahler, Non Hodgkin, Hodgkin, Leukemie of Borstkanker. Deze patiënten kriigen verschillende behandelingen. Meestal is er sprake van zware anti-tumor behandelingen door middel van chemotherapie. Omdat beenmergcellen erg gevoelig zijn voor chemotherapie, worden deze bij behandelingen met hoge doses chemo beschadigd. Bij sommige patiënten is dat ook de bedoeling, omdat bij hen door de kanker het beenmerg juist is aangetast. Bij andere patiënten, bijvoorbeeld bij patiënten met een mammacarcinoom, is dat niet de bedoeling maar een gevolg van behandeling. Als beenmerg van patiënten door de behandeling vernietigd wordt, komen deze patiënten in aanmerking voor een Beenmerg Transplantatie (BMT). Bij een BMT wordt beenmerg, indien dit gezond is, voorafgaand aan de chemo behandelingen bij patiënten via een operatieve ingreep weggenomen (een autochtone transplantatie). Dit beenmerg wordt na de behandeling via een infuus weer aan patiënten terug gegeven. Daarna volgt een periode van wachten. De vraag is of het beenmerg weer door het lichaam wordt geaccepteerd en of het opnieuw rode en witte bloedlichaampjes en bloedplaatjes gaat aanmaken. Dat duurt - als het goed is - een week of zes. In die periode worden patiënten geisoleerd verpleegd, omdat ze een vergrote kans hebben op infecties doordat de witte bloedlichaampjes - die zorgen voor de afweer van het lichaam - ook beschadigd zijn. Bij patiënten bij wie de beenmergcellen vóór de therapie met kanker zijn aangetast, wordt naar een donor gezocht die beenmerg heeft met 
zo veel mogelijk dezelfde typering (allogene BMT). De meeste kans een geschikte donor te vinden is binnen de directe familiekring. Na de chemo wordt beenmerg van de donor via een infuus bij de patiënt ingebracht. Ook deze patiënten moeten vervolgens geïsoleerd verpleegd worden en dan is het wachten op het stijgen van de cellen. Omdat het hier geen eigen beenmerg betreft, bestaat met name in dergelijke situatie de kans dat dit beenmerg afgestoten wordt. Patiënten worden daarom vaak behandeld met anti-afstotingsmedicatie.

Patiënten ondervinden allerlei problemen als gevolg van de ziekte zelf: koorts, gebrek aan eetlust, gewichtsverlies, moeheid, botpijn, bloedingen, infecties. Daarnaast krijgen ze ook klachten door de behandeling. Misselijkheid, braken, diarree, haaruitval zijn de 'gewone' bijwerkingen van chemotherapie. Door de behandeling met chemo worden de witte bloedlichaampjes die in het beenmerg worden aangemaakt beschadigd en verminderd de afweer van het lichaam. Patiënten hebben een vergrote kans op infecties aan de slijmvliezen, bijvoorbeeld van de mond, keel, ogen of vagina. Door het beschadigen van het beenmerg hebben de patiënten bovendien grotere kans op bloedingen, omdat de bloedplaatjes beschadigd zijn. Bovendien is het zuurstoftransport verstoord, omdat de rode bloedlichaampjes onvoldoende aangemaakt worden, waardoor allerlei organen beschadigd kunnen raken. Afstoting van het beenmerg is één van de complicaties die kan optreden. Verpleegkundigen zijn daarom zeer alert op koorts, koude rillingen, jeuk, en een schilferige huid. Van sommige complicaties is niet duidelijk waar zij vandaan komen of wat de betekenis ervan is. Daarom wordt allerlei aanvullend onderzoek gedaan. Er worden bijvoorbeeld longfoto's gemaakt of een ECG, EEG, maar ook meer intensieve en pijnlijke onderzoeken zoals darmonderzoek en beenmergpuncties.

Patiënten worden geconfronteerd met intensieve ingrepen aan hun lichaam. Op de eerste plaats om hen te behandelen voor een levensbedreigende aandoening. Op de tweede plaats ondergaan patiënten verschillende ingrepen aan en in hun lichaam om de hierboven genoemde complicaties en bijwerkingen te bestrijden. Op de derde plaats worden patiënten geconfronteerd met onderzoek om effecten van de behandeling vast te kunnen stellen en complicaties te kunnen diagnosticeren.

\section{Fysieke pijn en lijden}

In het nu volgende wordt besproken dat verpleegkundigen oog hebben voor fysieke pijn en lijden van patiënten en worden de manieren beschreven waarop ze in dergelijke omstandigheden voor patiënten zorgen. Om deze behoeften te beschrijven wordt een onderscheid gemaakt tussen situaties 
waarin patiënten zich zwak of beroerd en ellendig voelen, situaties waarin patiënten ernstig pijn lijden als gevolg van ziekte en behandeling en situaties waarin een ingreep aan het lichaam van een patiënt wordt uitgevoerd.

\section{Verlichten van de situatie}

Verpleegkundigen stimuleren patiënten tot allerlei activiteiten die nodig zijn om de lichamelijk conditie op peil te houden. Wanneer ze dat doen houden ze er rekening mee dat patiënten zich zwak of beroerd en ellendig kunnen voelen. Om de situatie voor patiënten die zich zo voelen te verlichten tonen ze begrip.

Verpleegkundige: "Als je pijn hebt en je moet je bed toch uit, ja en dat moet toch want decubitus is er gauw genoeg, dat is niet fijn. Daar moet je dan rekening mee houden. Niet dat je zegt zo van 'hup uit bed', maar dat je dat rustig en voorzichtig aanpakt. Dat zeg ik dan ook aan die mensen, 'doe maar rustig aan'." Verpleegkundigen geven patiënten ook positieve feedback. Ze complimenteren hen met het feit dat het hen toch nog lukt zichzelf te wassen, uit bed te komen of pillen te slikken, ondanks het feit dat ze zich zwak, beroerd en ellendig voelen.

Verpleegkundige: "Soms zeg ik dat ook tegen patiënten, 'U doet het goed' dan zeg ik 'dat $u$ toch nog uit bed komt, hoe u zich voelt', dat is knap'."

Daarnaast nemen verpleegkundigen zorg over wanneer patiënten daar behoefte aan hebben. Soms valt het patiënten namelijk erg zwaar om zichzelf te wassen, aan te kleden of uit bed te komen.

Verpleegkundige: "Soms denk ik 'dat kunnen die mensen toch zelf niet'. dat neem ik dan van hen over. Daar ben ik heel zorgzaam in."

Verpleegkundigen zoeken ook naar verlichting van de situatie voor patiënten door lichamelijke verzorging te geven. Deze heeft dan als het ware de betekenis van fysieke troost. Verpleegkundigen besteden veel aandacht aan lichamelijke verzorging van patiënten, omdat patiënten zich beter kunnen voelen als c'mand bijvoorbeeld een washandje op hun voorhoofd legt of hen de mond laat spoelen.

Vetrpletgkundige: "Ja, als jij hondsberoerd en kotsmisselijk in bed ligt, wil je ook eens even met rust gelaten worden, maar je moet er als verpleegkundige ouk weer zijn. Braken, washandje op het hoofd, even verkoelen, even de mond laten spoelen, even zitten, gewoon, die kleine rotdingetjes, maar dat is zinnig en zo gemakkelijk. Het kan zo veel zijn."

Patiënten kunnen zich soms ook minder beroerd en ellendig voelen, wanneer ze fris gewassen in bed liggen nadat ze onder de douche hebben gestaan. Verple'gkundige: "Juist mensen die ziek zijn en die daardoor niet meer in staat zijn om zelf onder de douche te gaan. Hen dan toch helpen onder de douche te gaan. En dan niet, omdat douchen lastig gaat, hen maar met een 
waterbakje op bed verzorgen. Dat is toch vaak niet echt lekker fris. Nee, dan toch helpen om fijn onder de douche te gaan. Ik weet dat mensen dat zalig vinden om stromend water over hun lijf te voelen, want dan zeggen ze ook 'heerlijk, ik heb al een hele week geen stromend water over mijn lijf gehad'." Een andere manier om ervoor te zorgen dat patiënten zich prettiger voelen is door - wat verpleegkundigen zelf noemen - aandacht te hebben voor de 'kleine dingen'. Deze 'kleine dingen' kunnen ervoor zorgen dat patiënten zich lichamelijk - en dus vaak ook psychisch - prettiger voelen.

Verpleegkundige: "Zorg, dat is aandacht voor zaakjes die niet strikt nodig zijn, maar wel heel fijn zijn. Van die kleine dingen zijn belangrijk. Die extra dingen. Haren wassen, nagels knippen. Daar knappen mensen van op." Wat dan goed is om te doen, als het gaat om het zoeken naar verlichting van de situatie, is voor patiënten verschillend. Welke fysieke troost gegeven wordt, is afhankelijk van de fysieke situatie van een patiënt. Hoe beroerd voelt deze patiënt zich? Tot welke fysieke activiteiten is een patiënt al dan niet in staat? Kan hij of zij wel uit bed om onder de douche te gaan? Bovendien is dat afhankelijk van de persoon van een patiënt. Wat vindt een patiënt prettig? Voor de ene patiënt betekent fysieke troost water over het lijf, terwijl een andere patiënt troost ervaart door gewassen te worden in bed.

Verpleegkundige: "Als dat kan natuurlijk. Soms kunnen patiënten niet onder de douche. Dan houdt het op."

Verpleegkundige: "Als hij dat dan fijn vindt, dan was ik hem op bed. Dan heeft hij zich 's ochtends al zelf aan de wasbak gewassen en dan heeft zo'n patiënt er behoefte aan lekker verzorgd te worden."

\section{Verlichten van ernstige pijn}

Patiënten hebben soms ernstig pijn als gevolg van ziekte en behandeling. Als patiënten ernstig pijn lijden geven verpleegkundigen ook fysieke troost en hebben aandacht voor 'kleine dingen'. Deze manieren van het verlichten van pijn kunnen echter in bepaalde sitauties onvoldoende zijn, hoewel deze er wel toe kunnen bijdragen dat pijn beter te verdragen is. In omstandigheden van ernstige of langdurige en intensieve pijn signaleren verpleegkundigen bij patiënten behoefte aan verlichting. Dat doen ze dan bijvoorbeeld in de vorm van: het bieden van comfort.

Tijdens de middagoverdracht wordt gesproken over mevrouw $\mathrm{x}$. Ze ligt alweer geruime tijd op de afdeling. Ze heeft een wond aan haar been die maar niet dicht wil. Het is een lelijke wond. Verpleegkundigen discussiëren over de vraag wat de beste manier is om de wond te verzorgen. Of er nog iemand naar x moet kijken? Misschien een dermatoloog? De UL zal het aan de artsen vragen. Ik observeer vandaag het handelen van Theo. Daarom loop ik met hem en Tanja mee naar de kamer van mevrouw x. Zij zijn verantwoor- 
delijk voor de achterste kamers. Mevrouw x ligt bleek en onderuitgezakt in bed. Theo haalt het verband van de wond. De wond begint zwart te worden aan de randen. Theo en Tanja kijken bezorgd. Ze vragen aan mevrouw $x$ hoe ze zich voelt. Of ze pijn heeft en of ze nog wel kan bewegen met dat been. Mevrouw x geeft aan dat ze inderdaad niet lekker ligt en pijn heeft. Ik word erop uitgestuurd om extra hulpmiddelen te halen. Er wordt een hele constellatie gebouwd van kussens en opgerolde dekens.

Verpleegkundigen signaleren bij deze patiënt niet alleen een verslechterde conditie van de wond, maar ook de pijn die hier het gevolg van is. De zwarte randen aan de wond worden niet slechts opgevat als een pathologische verandering van de wond, maar worden in verband gebracht met fysiek lijden. In het denken en handelen van verpleegkundigen is zichtbaar dat ze proberen patiënten comfort te bieden door het inzetten van middelen, zoals met kussens een betere houding in bed vinden, een dekenboog of een andere matras. In het denken en handelen van verpleegkundigen is zichtbaar dat ze voor patiënten die ernstig pijn lijden ook pijnmedicatie organiseren. Artsen zijn verantwoordelijk voor het voorschrijven van de pijnmedicatie. Soms doen artsen dit op eigen initiatief. Regelmatig attenderen verpleegkundigen hen er echter op dat patiënten pijn hebben, die volgens hen verlicht moet worden.

Verpleegkundige: "Wanneer ik vind dat een patiënt pijn lijdt en ik vind dat een arts daar onvoldoende oog voor heeft, dan blijf ik net zo lang doorzeuren totdat hij naar die patiënt toegaat. Patiënten hoeven hier geen pijn te lijden. Het is allemaal al erg genoeg. Aan pijn kunnen en moeten we iets doen." Verpleegkundigen kunnen zeer vasthoudend zijn wanneer ze vinden dat artsen niet op hun verzoek reageren.

Verpleegkundige: "En als ik dan vind dat de patiënt dat nodig heeft, dan blijf ik net zo lang doorzeuren totdat hij komt. Kan me niets schelen. Als de patiënt dat nodig heeft, dan doe ik dat."

\section{Verlichten van een pijnlijke ingreep}

Soms verrichten verpleegkundigen medisch-technische handelingen aan het lichaam van een patiënt. Ze zien daarbij pijnervaringen van patiënten bij het ondergaan van een dergelijke handeling.

Verpletgkundige: “En dat je dan niet zo van 'hup die spuit erin'. Patiënten maken hier heel wat mee. Zo'n spuit kan dan heel belastend en pijnlijk voor hen zijn. Daar moet je wel rekening mee houden."

Verpleegkundigen zien ook dat de werking van bepaalde medicatie ingrijpend voor patiënten kan zijn.

Verpleegkundige: "Ik bedoel maar, het is wel even chemo wat je aanhangt, daar mag je wel even aandacht voor hebben, vooral als het de eerste is voor mensen." 
Om een pijnlijke ingreep voor patiënten te verlichten hebben verpleegkundigen aandacht voor pijnervaringen van patiënten. Ze hebben er daarbij niet alleen oog voor, maar ook begrip voor. Door het denken, handelen en voelen van verpleegkundigen te bestuderen is ook zichtbaar geworden dat ze fl:xibul omgaan met de regels van het protocol, wanneer een situatie door een patiënt als erg pijnlijk en ingrijpend wordt ervaren. Ze wegen het lijden van patiënten af, tegen het effect dat met het uitvoeren van een protocol wordt beoogd. Verpleegkundigen verschonen bijvoorbeeld dagelijks de Hickmann van patiënten. De Hickmann is de centrale veneuze katheter die aan het begin van de opname operatief bij patiënten wordt ingebracht in een grote ader. Deze katheter wordt ingebracht om de aderen van de armen te sparen. Door het toedienen van chemo, transfusies en andere medicatie en door het afnemen van bloed zouden deze snel beschadigen en pijnlijk worden. Deze katheter kan gedurende langere tijd blijven zitten, zodat bij patiënten niet steeds weer opnieuw een infuus moet worden aangelegd en bloed via de Hickmann verkregen kan worden. Deze Hickmann moet regelmatig verzorgd worden, om te voorkomen dat hij dicht gaat zitten of gaat ontsteken. Bij het uitvoeren van deze handeling gebruiken verpleegkundigen een protocol. Verpleegkundige hebben bij het uitvoeren van het protocol, er oog voor wat het betekent om een Hickmann te hebben.

Verpleegkundige: "Bijvoorbeeld het protocol van de Hickmann verzorging. Dat was dan weer die jongen van veertien. En daar had ik toch al een beetje meer de neiging om wat soepeler te zijn. Maar je kunt dus kiezen uit een witte pleister met gaas eronder of een doorzichtige pleister zonder gaas eronder. En je gebruikt die doorzichtige pleister als de Hickmann nog lekt of als hij vers is, als het onrustig is, zodat je de insteekopening kunt inspecteren. En die doorzichtig zijn ook wat beter, want die zijn luchtdicht en daarom wat beter voor het wondje in verband met infectiegevaar. Maar die jongen, die vond dat zo verschrikkelijk eng, dat gaatje, dat slangetje in zijn borst. Dat vond hij zo eng om te zien. Er moest dus eigenlijk een doorzichtige pleister op, voor het infectiegevaar. Toen vroeg hij aan me of daar een gaasje onder mocht, zodat hij de insteek opening toch maar niet zag. En volgens protocol mag dat niet, dat moet vrij zijn, want de wond was een heel klein beetje rood. Maar dan denk ik, ja, is het echt een groot probleem om een gaasje eronder te doen? Dat moet je je dus afuragen."

Deze verpleegkundige kiest ervoor om flexibel om te gaan met de regels van het protocol en toch een gaasje onder de doorzichtige pleister te gebruiken, omdat hij denkt dat deze patiënt er behoefte aan heeft niet voortdurend geconfronteerd te worden met een slangetje dat in zijn lichaam verdwijnt. Rekening houden met gevoelens van een patiënt, wordt afgewogen tegen de vraag hoeveel schade de patiënt oploopt of kan oplopen. Als de wond echt 
geinfecteerd was geweest, dan had de verpleegkundige naar andere wegen moeten zoeken om het lijden voor deze patiënt te verminderen.

Verpleegkundige: "Niet zo maar zeggen van 'hij wil het, dus ik doe het zo'. Maar je moet jezelf afvragen 'wat is op dit moment belangrijker?'. Als het wondje nu echt onrustig was en je moest de insteekopening inspecteren, dan gaat het niet door. Dan moet hij er maar omheen kijken. Maar als het kan, ja dan."

In het denken en handelen van verpleegkundigen is zichtbaar dat de vraag of al dan niet rekening gehouden wordt met ervaringen van patiënten op een bepaald moment, geen zaak is van louter medeleven. Het is een weloverwogen beslissing, waarbij medisch-technische kennis wordt afgewogen tegen de betekenis die een bepaalde ingreep voor een patiënt heeft. Een volgende manier om een pijnlijke ingreep voor een patiënt te verlichten, is door tegen opdrachten van artsen in te gaan. Bijvoorbeeld wanneer verpleegkundigen bloed moeten prikken bij een patiënt. Bij patiënten die chemo krijgen moet vaak en veel bloedonderzoek worden verricht, om de effecten van de behandeling te kunnen vaststellen of om complicaties te kunnen diagnosticeren. Dat is één van de redenen dat patiënten een Hickmann hebben. Soms krijgen verpleegkundigen de opdracht van artsen om uit de arm bloed te prikken, wanneer een patiënt koorts heeft. Om 'schoon' bloed te krijgen, dat niet vervuild is door de lijnen van de Hickmann, moet een ader worden aangeprikt.

Verpleegkundige: "Soms moeten we bloedprikken bijvoorbeeld, en dan is de patiënt is al drie dagen geprikt omdat hij temp heeft. Uit de Hickmann oké, dat is niet pijnlijk, maar de patiënt moet dan toch uit de arm geprikt worden. En dan heb ik zoiets van, ik bel en ik zeg 'de patiënt is niet te prikken', zeg ik dan gewoon. Ik heb zoiets van 'sorry'. Of de patiënt moet dan al veertig hebben, dat is wat anders, maar als hij 38,6 heeft, nee sorry, dan vind ik dat het niet moet. Ik zeg 'als die andere drie dagen gekweekt zijn. dan vind ik het goed', dan zeg ik 'ik krijg niet geprikt', zeg ik dan gewoon. En dan heb ik het niet geprobeerd. Dan spijt het me. Dan doe ik het wel uit de Hickmann, dan hebben ze die kweek in ieder geval. Maar dat doe ik de patiënt niet aan. Ja, want de patiënten vinden dat heel erg hoor en heel belastend, en dan heb ik zoiets van 'nee'. Ik zeg tegen de patiënt 'hoef niet te prikken, ik heb de dokter gebeld, ik heb gezegd dat $u$ heel slecht te prikken bent'. En deze patiënten zijn meestal slecht te prikken, want ze hebben niet voor niets de Hickmann. Dus ik heb zoiets van 'ik doe het gewoon niet'. En ja, ik vind, je moet de patiënt toch ergens ook beschermen, zeg ik altijd maar. Die dokters kunnen wel veel willen. Als ze daar zelf eens liggen, zeg ik altijd, wacht maar."

Zoals bovenstaande illustreert gaan verpleegkundigen soms tegen een opdracht van een arts in, om een patiënt niet lastig te vallen met de zoveelste pijnlijke ingreep aan het lichaam. Om een dergelijke afweging te kunnen maken, 
moeten verpleegkundigen niet alleen een beeld krijgen van individuele zorgbehoeften van patiënten en bijvoorbeeld weten dat deze patiënt bloedprikken als pijnlijk ervaart, maar ook medisch-technische kennis hebben. Bovenstaande verpleegkundige maakt bijvoorbeeld een onderscheid tussen een patiënt wiens bloed al drie dagen gekweekt is en nu 38,6 heeft of een patiënt die 40 temp heeft. Om de situatie voor patiënten draaglijker te maken, hebben verpleegkundigen kennis nodig om te weten waar de grenzen liggen.

In het voorafgaande zijn interventies besproken die door patiënten als pijnlijk kunnen worden ervaren en die door verpleegkundigen zelf worden uitgevoerd. Sommige interventies aan het lichaam van patiënten worden door andere zorgverleners verricht. Verpleegkundigen gaan ervan uit dat patiënten daarbij behoefte kunnen hebben aan iemand die hen bijstaat. Eén van de ingrepen die patiënten regelmatig ondergaan, is een beenmerg punctie. Om te bepalen of de cellen van een patiënt stijgen na een beenmergtransplantatie - een teken dat de behandeling is aangeslagen - wordt regelmatig bij een patiënt een punctie uitgevoerd. Verpleegkundigen assisteren artsen, wanneer deze een beenmergpunctie uitvoeren. Ze zetten alle benodigdheden klaar en rijken artsen instrumenten aan. Wanneer verpleegkundigen artsen assisteren bij een beenmergpunctie, hebben ze tegelijkertijd aandacht voor ervaringen van patiënten bij het ondergaan van een dergelijke ingreep. Ze assisteren daarom niet alleen artsen, maar staan patiënten bij in de betekenis van: er letterlijk naast staan, de hand vast houden en begrip tonen.

Ik observeer vandaag het handelen van de unitleider (UL). De artsen beslissen dat $x$ een beenmergpunctie krijgt. Deze patiënt vindt dat verschrikkelijk. De UL helpt $x$ op zijn zij te gaan liggen en een goede houding te vinden. Gedurende de punctie staat hij aan de kant van het gezicht van $\mathrm{x}$, terwijl de artsen achter zijn rug het werk doen. De UL houdt de hand van $x$ vast. Deze knijpt hem helemaal fijn en houdt voortdurend oogcontact. Als de punctie klaar is en we op de gang zijn vertelt de UL dat het belangrijk is dat er iemand bij staat om de patiënt te ondersteunen. In ieder geval bij patiënten die een punctie verschrikkelijk vinden. Vooral als je zo op ie zij ligt en de artsen zich achter je bevinden, wat natuurlijk niet anders kan bij een beenmergpunctie, dan is het belangrijk dat iemand aan de kant van de patiënt staat. Wat ook gebeurt is dat verpleegkundigen patiënten in bescherming nemen, door ervoor te zorgen dat een bepaalde interventie niet wordt uitgevoerd.

Verpleegkundige: "Bij ons zijn nu een paar patiënten die chemo moeten krijgen en zijn moeilijk te prikken. En dan doet zo'n arts dus, die prikt twee keer, prikt drie keer en dan wou hij dus de vierde keer gaan prikken. Dan zeg ik 'ho, wil je eventies meelopen naar de gang?'. En dan zeg ik hem 'nee, dat gaat me een beetje te ver, als het niet lukt dan moet je ophouden, dan moet je een ander vragen.' Je kunt niet vier, vijf of zes maal een naald erin prikken alsof 
het een borduurlapje is!' Dan zeg ik 'nee, dat doen we niet'. Nou ja! Als ik het genoeg vind, dan vind ik het genoeg. Dan vraagt hij maar een ander. Dat is dan spijtig genoeg voor hem, maar dan vind ik niet dat hij het recht heeft om inderdaad die mens in dat bed als borduurlap te gaan gebruiken en dan huppekee, voor de vierde keer nog maar eens, of de vijfde maal, nee."

Verpleegkundigen hebben er oog voor dat patiënten pijn verschillend kunnen ervaren. Sommige patiënten hebben bijvoorbeeld veel last van een beenmergpunctie, terwijl andere patiënten dat als minder ingrijpend en pijnlijk ervaren.

Ik loop met de unit leider (UL) mee. Hij assisteert bij twee beenmergpuncties. Bij de ene patiënt (die ik hierboven heb beschreven) was er paniek toen de artsen aan zijn bed kwamen. 'o nee, niet alweer' en hij gaf voortdurend aan dat hij pijn had gedurende de ingreep. Deze patiënt ervoer de ingreep als pijnlijk en hij was erg angstig. Bij de volgende patiënt leek het wel alsof er niets aan de hand was. Toen de artsen aan zijn bed kwamen ging hij gelaten op zijn zij liggen. Ook gedurende de ingreep zelf, maakte hij niet de indruk er veel last van de hebben.

Hij zocht geen oogcontact en hield geen hand vast.

Patiënten hebben verschillende behoeften aan zorg. Bij patiënten die de ingreep als pijnlijk ervaren, is in het handelen van verpleegkundigen te zien dat ze er oog voor hebben dat deze patiënten behoefte hebben aan steun bij het ondergaan van de behandeling. Ze willen volgens verpleegkundigen graag dat iemand hen bijstaat, bijvoorbeeld de hand vasthoudt, zodat het moment draaglijker wordt. In het denken en handelen van verpleegkundigen is ook zichtbaar dat ze er niet alleen oog voor hebben dat patiënten een andere pijnervaring kunnen hebben, maar dat patiënten aan pijn een ver. schillende betekenis kunnen geven. Voor sommige patiënten kan pijn een vanzelfsprekend deel van hun leven zijn.

Verpleegkundige: "Je hebt patiënten die met pijn kunnen leven. Daar moet je ook aandacht voor hebben."

Er zouden zelfs patiënten kunnen zijn die uit schuldgevoel niet van hun pijn verlost willen worden, al is dat - volgens een verpleegkundige - nog niet op de afdeling voorgekomen.

Verpleegkundige: "Eigenlijk willen de meeste mensen geen pijn lijden. Bijna iedereen wil ervan af. Ik ken wel situaties waarin mensen in eerste instantie geen pijnbestrijding willen, omdat ze bang zijn om verslaafd te raken. Maar als je het dan uitlegt dan willen ze dat wel. Misschien dat er mensen zijn die uit schuldgevoel aan hun pijn vasthouden, omdat ze kanker hebben en denken dat ze dat zelf schuld zijn omdat ze niet gezond hebben geleefd of zo. Maar dat heb ik eigenlijk nog nooit meegemaakt."

In deze paragraaf zijn zorgbehoeften van patiënten besproken die volgens verpleegkundigen het gevolg zijn van fysieke pijn en lijden. Verpleegkundigen 
verrichten allerlei activiteiten (schuin gedrukt) die erop gericht zijn ervoor te zorgen dat patiënten zo goed als mogelijk is hun situatie kunnen verdragen.

\section{Overrompeld door de behandeling}

Wanneer het gaat om zorgbehoeften die samenhangen met intensieve ingrepen die patiënten op de afdeling ondergaan, is in het denken en handelen van verpleegkundigen nog een tweede categorie zorgbehoeften geïdentificeerd. Patiënten worden op afdeling ro met ingewikkelde en ingrijpende behandelingen en onderzoeken geconfronteerd. Er komt veel op hen af. Bovendien wordt er vaak tempo gemaakt. Artsen willen bij opname zo snel mogelijk herstarten met de behandeling. Er zijn patiënten die daar weinig of geen last van hebben en die de hoeveelheid en snelheid van behandelingen en onderzoeken kunnen verdragen. Maar verpleegkundigen ontmoeten ook patiënten die zich in dergelijke omstandigheden overvallen en overrompeld voelen door het hele gebeuren.

Verpleegkundige: "Nou, deze patiënt, opgenomen met een acute leukemie.

Een mevrouw van middelbare leeftijd, eind 50. Gehuwd en een aantal kinderen die uitwonend zijn. Overgenomen van een ander ziekenhuis. Totaal overrompeld door de hele situatie. Ze krijgt dan allerlei onderzoeken die moeizaam verlopen. Allemaal beenmergpuncties die heel moeilijk gaan. Er moet allemaal bloed geprikt worden. Allemaal toestanden."

Wanneer patiënten zich overvallen en overrompeld voelen door de behandeling, proberen verpleegkundigen met hen te zoeken naar een situatie die $z^{\circ}$ kunnen verdragen.

\section{Zeggenschap over het eigen lichaam bevorderen}

In het denken en handelen van verpleegkundigen is zichtbaar dat ze oog hebben voor behoeften van patiënten die samenhangen met het behouden of verkrijgen van zeggenschap over hun eigen lichaam. Sommige patiënten hebben de behoefte alles te weten over de behandeling en zelf keuzes te maken.

Verpleegkundige: "Je hebt mensen, die willen alles weten over een behande-

ling, zodat ze zelf kunnen beslissen."

Tegelijkertijd bevinden patiënten zich volgens verpleegkundigen in een situatie waarbij er, ten aanzien van behandelingen, niet zo veel te kiezen valt.

Verpleegkundige: "Je wilt dat mensen kunnen zeggen 'daar kies ik voor'. Je wilt als verpleegkundigen dan eigenlijk een soort stramientie volgen. De patiënt moet starten met behandeling. En eigenlijk wil je dan dat de patiënt voordat die start ook op de hoogte is van de voor-en nadelen. Dat je ook kunt zeggen 'daar kies ik voor', als er al wat te kiezen valt." 
Verpleegkundige: “Je zou eigenlijk ook wel willen dat ze ook zelf keuzes konden maken, maar bij ons is het vaak toch zo dat mensen in een bepaalde trial of onderzoek komen waardoor er niet zo veel te kiezen valt. Aan het begin wordt gekozen, tussendoor niet, behalve als de situatie verandert, en dan nog, er valt niet veel te kiezen. Artsen stellen iets voor. Als patiënt weet je het dan toch ook niet."

De behandelingen die patiënten krijgen zijn medisch erg ingewikkeld, waardoor het moeilijk is er inzicht in te krijgen en keuzes te maken. Bovendien worden patiënten vaak in een bepaalde behandeling en trial meegezogen, zodat ze er tussentijds niet uit kunnen stappen. In situaties waarin zelf keuzes maken ten aanzien van behandeling nauwelijks mogelijk is, zoeken verpleegkundigen naar manieren waarop ze patiënten kunnen steunen om zeggenschap te behouden of verkrijgen over hun eigen lichaam.

In het denken en handelen van verpleegkundigen is zichtbaar dat ze patienten steunen in het verkrijgen of behouden van zeggenschap over hun eigen lichaam, door hen bijvoorbeeld te informeren over medisch-technische behandelingen. Patiënten krijgen van artsen te horen welke behandeling ze ondergaan of aan welke trials ze meedoen. Vaak komen daarna de vragen. Verpleegkundigen praten daarom veel met patiënten over behandelingen, bijwerkingen, complicaties en onderzoeken. Soms geven verpleegkundigen ongevraagd informatie, omdat ze ervan uitgaan dat patiënten deze nodig hebben om zeggenschap te behouden over hun lichaam.

Dirk legt aan meneer $x$ nog eens uit aan welk onderzoek hij mee doet. 'Dus als ik het goed begrijp' zegt meneer x 'dan kan ik niet met dat medicijn stop. pen als ik dat zou willen'. 'Nee' legt Dirk nog eens uit. 'Als je daar eenmaal mee begint moet je dat afmaken, want anders wordt je lichaam nog veel zieker'. Zo had meneer $x$ die informatie die hij van de arts gekregen had niet begrepen. Daar ging hij toch nog eens over praten met de arts.

Verpleegkundige: "Ie probeert patiënten voor te bereiden op de visite van artsen. 'Maak een briefje voor u zelf of stel vragen op', zeg je dan."

Verpleegkundigen geven informatie, zodat patiënten weten waar ze op moe. ten letten of waarnaar ze moeten vragen. Een andere manier waarop verpleegkundigen proberen de zeggenschap van patiënten te vergroten, is door te wijzen op situaties waarin patiënten hun stem kunnen laten horen. Verpleegkundigen wijzen patiënten er bijvoorbeeld op dat ze hun twijfels aan artsen kunnen voorleggen tijdens de dagelijkse artsenvisite.

Mevrouw $x$ stelt veel vragen aan Petra over de behandeling die ze krijgt. Ze snapt eigenlijk niet wat er precies gebeurt. Petra stelt voor dat mevrouw $x$ deze vragen aan de arts stelt. Zo meteen wordt er visite gelopen. Deze momenten kan mevrouw $x$ gebruiken om vragen te stellen. 
Verpleegkundigen attenderen patiënten op beslismomenten, waarbij inspraak mogelijk is.

Lieve praat met mevrouw $x$. Haar huid is heel schilfering. Ze heeft koorts en diarree. Ze kan nauwelijks iets eten. Artsen willen een maagonderzoek bij haar doen, om een diagnose te kunnen stellen. Lieve praat daarover met mevrouw $\mathrm{x}$. Waarom dat onderzoek al dan niet nodig is. Hoe het onderzoek in zijn werk gaat. Ze zegt ook wat ze daar zelf van vindt en ze vraagt of mevrouw $x$ het wel wil. Later zegt Lieve tegen mij dat ze wil voorkomen dat artsen zo vanzelfsprekend maar weer een onderzoek laten doen. Dat is allemaal heel erg belastend voor deze mevrouw. Lieve wil dat ze van tevoren de kans krijgt erover na te denken of ze het wil. Dat ze de goede vragen aan artsen kan stellen om zicht te krijgen op de vraag waarom dit onderzoek nodig is en of er wel consequenties verbonden kunnen worden aan de uitslag. Verpleegkundigen wijzen patiënten niet alleen op ruimte waarin ze hun stem kunnen laten horen, maar helpen patiënten ook ruimte te creëren.

Mevrouw $\mathrm{x}$ klaagt tegen Petra dat de visites eigenlijk veel te snel gaan. Ze heeft niet het gevoel dat er tijd is voor haar vragen. Petra zegt tegen mevrouw $x$ dat zij ook kan overwegen een gesprek aan te vragen met de arts. Verpleegkundigen zoeken met patiënten naar een gelegenheid om met artsen over ziekte en behandeling te praten.

Wanneer verpleegkundigen patiënten ondersteunen bij het behouden of verkrijgen van zeggenschap over hun lichaam, dan houden ze er rekening mee dat het voor patiënten niet altijd nodig is om overal evenveel zeggenschap over te hebben om de situatie te kunnen verdragen.

Verpleegkundige: "Wat me bij die meneer opvalt is dat hij eigenlijk in alles wat artsen voorstellen meegaat. Over de behandeling heeft hij weinig te melden.

Maar als het gaat over de vraag hoe die wond verzorgd moet worden, dan heeft hij veel vragen."

Soms hebben patiënten geen behoefte aan inspraak op grote lijnen, maar hebben het nodig meer te denken over details. Van de andere kant zijn er ook patiënten die geen behoefte aan inspraak hebben als het gaat om details binnen de behandeling. Zij hebben vooral zeggenschap over de grote lijnen nodig om de situatie te kunnen verdragen.

Verpleegkundige: "Mevrouw $\mathrm{x}$ heeft ingestemd met de behandeling. $\mathrm{Nu}$ laat ze het verder aan de artsen over. Ze wil er eigenlijk niet te veel over horen." In het voorafgaande is belicht dat verpleegkundigen patiënten ondersteunen in het verkrijgen of behouden van zeggenschap over hun eigen lichaam. Om aan deze behoeften tegemoet te komen verstrekken verpleegkundigen bijvoorbeeld medisch-technische informatie, wijzen ze patiënten op situaties waarin ze hun stem kunnen laten horen of creëren ze voor patiënten ruimte om inspraak te hebben. In het vervolg van deze paragraaf wordt besproken 
dat verpleegkundigen ook geconfronteerd worden met patiënten die juist: geen zeggenschap willen, omdat ze dit als last ervaren.

\section{Zeggenschap overnemen}

Verpleegkundige: “... Die meneer, die was zo in paniek, die hoorde gewoon niet wat je zei. Dat ging het ene oor in en het andere oor uit. Soms zijn mensen zo in paniek van de diagnose, die moet je dan niet te veel vertellen en maar even laten...."

Soms zijn patiënten niet in staat informatie te bevatten, omdat ze ontdaan zijn door de diagnose. In dergelijke omstandigheden is het handelen van verpleegkundigen er niet zozeer op gericht patiënten te ondersteunen hun zeggenschap te behouden of te verkrijgen. Het handelen is erop gericht patiënten zo veel mogelijk te ontzien.

Verpleegkundige: "Vroeger vond ik dat ik moest informeren en dus deed ik dat ook bijna altijd. Maar daar ben ik nu echt van afgestapt. Ik doe nu meer informatiegesprekken en dergelijke, eigenlijk op indicatie. Dat ik zeg 'nu is het nodig of nu is het niet nodig'. Want als ik denk 'hij snapt het niet of hij kan het niet verwerken', dan zal ik het ook niet doen. Vroeger deed ik het maar eigenlijk. Nu heb ik zoiets van, nu selecteer ik veel meer. Misschien dat ik nu iets meer bepaal van 'nou moet ik dit zeggen en dit heeft nu geen zin om te zeggen'. Maar dat is ook vaak de ervaring, als je terugkijkt. Nu denk ik 'dat heeft ze nu niet nodig'. Als zij een half antwoord weet, vind ik het belangrijk om het volledig uit te leggen. Dat kun je goed polsen. Als je op een vraag al het halve antwoord krijgt, dan vind ik dat een teken dat ik er dieper op in moet gaan."

Wanneer gesprekken met patiënten over ziekte en behandeling voor hen te belastend zijn, worden dergelijke gesprekken uitgesteld.

Verpleegkundige: "Kijk, als ik zie dat het iemand allemaal te veel is, dan ga ik niet staan drammen zo van 'snapt $\mathrm{u}$ wel welke behandeling $\mathrm{u}$ krijgt of waarom dat onderzoek is', dan denk ik laat nog maar even zo. Mensen hebben daar op dat moment niets aan. Dat moet je dan ook laten."

In het denken en handelen van verpleegkundigen is zichtbaar dat ze rekening houden met de persoon en situatie van een patiënt, als het gaat om de vraag in hoeverre een patiënt zeggenschap over de eigen situatie nodig heeft. Sommige patiënten ervaren dit als een belasting.

\section{Betrokkenheid bij de behandeling bevorderen}

Sommige patiënten hebben volgens verpleegkundigen minder behoefte aan zeggenschap, maar willen dat ook niet helemaal overdragen. Deze patiënten kunnen er vooral behoefte aan hebben, om op de één of andere manier betrokken te zijn bij de behandeling. 
Verpleegkundige: "Het gaat om hen, hun lichaam, het kan voor hen belangrijk

zijne het gevoel te hebben dat ze mee doen, erbij blijven."

Op verschillende manieren proberen verpleegkundigen tegemoet te komen aan deze behoefte van patiënten. Eén manier om patiënten te betrekken bij de behandeling, is door hen inzicht te geven in hun eigen situatie. Sommige patiënten willen graag weten welke behandeling hun lichaam ondergaat, wat de bedoelde effecten zijn en welke complicaties kunnen optreden. Niet zo zeer om zeggenschap te verkrijgen, maar om inzicht te hebben in hun eigen situatie en om niet voortdurend met onverwachte gebeurtenissen geconfronteerd te worden.

Tijdens de verzorging stelt meneer x vragen aan Ineke. Hij snapt niet hoe het zit met het stijgen van de cellen. Wat betekent dat nu precies? En wat gebeurt er als ze niet gaan stijgen? Ineke en hij praten er een tijdje over. Ze legt hem nog eens uit welke behandeling hij krijgt en hoe het succes van de behandeling vastgesteld kan worden. Later zegt ze tegen mij 'dat mensen weten wat er aan de hand is en wat hen te wachten staat, dat is belangrijk, anders worden ze iedere keer weer overvallen en overrompeld overal door, dat is voor mensen niet fijn'."

Om patiënten te betrekken bij de behandeling, laten verpleegkundigen hen ook meedoen. Dat doen ze door hen te laten meekijken en vergelijken. Verpleegkundigen gaan ervan uit dat patiënten niet machteloos willen toezien, maar er behoefte aan hebben te volgen wat er in en met hun lichaam gebeurt.

Verpleegkundige: "Patiënten moeten niet machteloos langs de kant staan. Het is belangrijk dat ze met hun eigen behandeling bezig zijn. Dat is ook wat het zo leuk maakt. Je bent toch continu met de patiënt bezig. Met de patiënt zelf. Met zijn proces. Zodat ze zelf kunnen vergelijken of dat wondje dat ze hier hadden verbetert. Of dat de plekken op de armen minder worden. Dat moet je ook aan hen vragen. Je kunt wel kijken en niets zeggen. Maar het is heel belangrijk, denk ik, voor een patiënt dat hij het gevoel heeft dat hij zelf met zich zelf, met zijn gezondheid, bezig is."

\section{Een compagnon zijn}

Het zoeken naar een acceptabele verhouding ten opzichte van de behandeling is voor patiënten van afdeling Io vaak moeilijk. Patiënten krijgen intensieve en ingewikkelde behandelingen en allerlei aanvullend onderzoek, om effecten van behandelingen te bepalen en complicaties te diagnosticeren. Bovendien maakt een confrontatie met de eindigheid van het bestaan patiënten vaak bang en onzeker. In een dergelijk proces hebben patiënten vaak behoefte aan iemand die met hen meedenkt en hen het gevoel geeft dat ze er niet alleen voor staan. 
Verpleegkundige: "Dat is natuurlijk van echt patiëntgericht verplegen een groot voordeel. Ook zelf mee visite lopen. Iij weet wat de patiënt weet, je kunt dingen aanvoelen, je kunt naderhand eventjes kijken of ze het begrepen hebben en terugkoppelen. Dat is toch heel belangrijk. Dat je met hen meegaat." Patiënten hebben er volgens verpleegkundigen vaak behoefte aan dat verpleegkundigen betrokkenen zijn bij het hele proces. Niet alleen om vragen van patiënten beantwoorden en onduidelijkheden wegnemen, maar om mee te denken, mee te overwegen, mee te vechten.

Verpleggkundige: "Je vecht samen met hen eigenlijk. Je gaat het gevecht om te overleven samen met hen aangaat. Dat is het eigenlijk. Familie is er vaak natuurlijk. Artsen ook. Maar wij zijn er toch dag en nacht en op alle moeilijke momenten. Ook op de mooie momenten. Als de cellen dan eindelijk gaan stijgen. Dat is prachtig. Dat is feest. Maar er zijn veel moeilijke momenten. Heel moeilijk en dat patiënten dan het gevoel hebben dat je ernaast staat en het meebeleeft. Dat ze met jou kunnen overleggen, twijfels bespreken, dat soort dingen. En dan weten ze dat jij hun situatie kent en je kent hen, dus je kunt dan ook meepraten over wat dan het beste is om te doen. Tot op zekere hoogte dan. Mensen vragen wel eens 'wat zou jij doen'. En dan denk ik ook wel met hen mee. Maar uiteindelijk kan ik dan niet zeggen je moet dit of dat doen. Dat kan ik toch niet. Ik kan wel zeggen hoe ik erover denk. Hoe het voor mij voelt. Of hoe ik denk dat zij erin staan."

Om. een compagnon te kunnen zijn is er vertrouwen nodig. Los van de vraag hoeveel inspraak een patiënt in zijn of situatie nodig heeft, is het volgens verpleegkundigen van belang dat er vertrouwen is. Zowel patiënten die zeggenschap belangrijk vinden, als ook patiënten voor wie dat niet het geval is, moeten kunnen vertrouwen op de deskundigheid en goede bedoelingen van artsen en verpleegkundigen.

Verplecgkundige: "Ik weet alles, nou ja alles is overdreven, maar wel heel veel, over ziekte en behandeling. Daardoor hebben patiënten ook vaak vertrouwen in me. Die weten dat het klopt wat ik zeg en dat ik het ook zeg als $i k$ iets niet weet en dat ik het dan ga uitzoeken. Wanneer mensen je vertrouwen in je kennis, dan vertrouwen ze je ook vaak op ander vlak. Dat zij of ook familie met je praten over hoe ze dit met elkaar opvangen en zo. Wanneer je veel weet, veel kennis hebt van medische zaken, dan vertrouwen patiënten je ook. Dan vragen ze wat ze moeten doen en dan komen ze ook met andere vragen bij je. Niet over medische zaken, maar hoe ze zich voelen en zo."

Verpleegkundige: "Voor patiènten is het belangrijk dat ze vertrouwen hebben. In ons, dat wij het goed doen, maar vooral in artsen. Ze geven zich als het ware over aan ons, dan moet je wel het gevoel hebben dat dat te vertrouwen is. Ze kunnen ook niet alles overzien. Vooral van de behandeling niet. Dat kun je nog zo goed proberen uit te leggen. Veel mensen snappen dat gewoon 
niet. Die willen dat ook niet. Die willen ervan uitgaan dat artsen wel weten wat ze doen."

Patiënten hebben het gevoel nodig, dat ze in goede handen zijn. Dat geldt ook voor familie. Wanneer familie het gevoel heeft dat bepaalde artsen of verpleegkundigen niet deskundig zijn of dat de patiënt hen niet echt interesseert, dan hebben ze er erg veel moeite mee hun naaste in die handen achter te laten.

Verpleegkundige: "De man van mevrouw x zegt tegen Renee dat hij het niet fijn vindt als verpleegkundige $\mathrm{x}$ een infuus aanhangt. 'Die verpleegster geeft me het gevoel dat ze niet weet waarmee ze bezig is'. De man van mevrouw $\mathrm{x}$ vindt dat vervelend. Hij let altijd goed op als hij er is, maar ja, hij is er niet altijd." In deze paragraaf zijn zorgbehoeften aan de orde gekomen die samenhangen met intensieve behandelingen en ingrepen die patiënten aan hun lichaam ondergaan. Er is zichtbaar gemaakt dat verpleegkundigen daarbij bijvoorbeeld proberen om fysieke pijn en lijden van patiënten te verlichten. Bovendien proberen ze ervoor te zorgen dat patiënten zich niet overrompeld voelen door allerlei ingrepen, behandelingen en onderzoeken die elkaar vaak in een snel tempo opvolgen.

\section{OPGENOMEN ZIJN OP EEN ZIEKENHUIS AFDELING}

In de vorige paragraaf zijn zorgbehoeften beschreven in het denken en handelen van verpleegkundigen, die samenhangen met de behandelingen en onderzoeken die aan het zieke lichaam van patiënten worden uitgevoerd. Om deze behandelingen te ondergaan worden ze opgenomen op een afdeling in het ziekenhuis, weg van de vertrouwde omgeving en weg van thuis. In deze paragraaf worden zorgbehoeften belicht die samenhangen met het opgenomen zijn in het ziekenhuis.

\section{Niet thuis maar in het ziekenhuis}

In deze paragraaf wordt beschreven in welke omgeving patiënten terecht komen, wanneer ze op afdeling ro zijn opgenomen. Afdeling ro is een hematologische oncologische afdeling binnen een academisch ziekenhuis. Deze afdeling heeft 18 bedden op negen kamers. Er is een drietal twee-persoonskamers en een drietal vier-persoonskamers. Daarnaast zijn er vier isolatie kamers. Hier liggen patiënten die geheel of gedeeltelijk geisoleerd verpleegd moeten worden, omdat ze intensieve chemokuren krijgen of een BMT. Geisoleerd verpleegd worden betekent dat iedereen die de kamer binnengaat zich in de sluis tussen gang en kamer moet verkleden: steriele jas aan, mondmasker voor, overschoenen aan. Patiënten zien altijd mensen voor zich, die ver- 
kleed zijn en een mondmasker voor hun gezicht hebben. Bovendien ruiken bezoekers altijd naar desinfecterend middel, omdat ze hun handen hiermee moeten wassen voordat ze de kamer betreden. Er lopen veel mensen rond op deze afdeling. Het verpleegkundig team bestaat uit 2I verpleegkundigen. I4 vrouwen en zeven mannen. Deze worden met name gesteund en begeleid door de unitleider. Het hoofd van de afdeling neemt de organisatie op afstand waar en is weinig aanwezig op de werkvloer. Aan de afdeling zijn verschillende artsen verbonden: twee zaalartsen, arts-assistenten die meestal de hele dag door op de afdeling aanwezig zijn, evenals steeds wisselende studenten geneeskunde die hun co-schappen lopen. De zaalartsen staan onder begeleiding en supervisie van een specialist en professor. Deze zijn zo af en toe op de afdeling. Daarnaast zijn er regelmatig andere hulpverleners aanwezig: maatschappelijk werkster, fysiotherapeut, diëtiste en pastor. Patiënten kunnen ook in aanraking komen met mensen van de prikdienst, van de röntgen, van het voedingsteam en dergelijke. Ook zijn er vrijwilligers op de afdeling aanwezig, die samen met patiënten de voedingslijst invullen en boeken en kranten rondbrengen.

Op afdeling ro lopen voortdurend allerlei mensen rond, waarvan het voor patiënten niet altijd even duidelijk is wie het zijn of wat ze daar doen. Piepers piepen, bedden worden rondgereden, apparaten voor onderzoek worden over de gang gereden, eten en drinken wordt rondgebracht, po's geleegd, nieuwe opnames komen binnen. Voor patiënten is deze afdeling vreemd en kan heel onoverzichtelijk en hectisch op hen overkomen, waardoor ze zich soms niet op hun gemak voelen. Toch moeten ze in een dergelijke omgeving vaak gedurende langere tijd verblijven. Soms wel twee maanden, wanneer ze bijvoorbeeld voor een BMT zijn opgenomen. Bovendien moeten ze in die tijd ook nog eens ingrijpende behandelingen aan hun lichaam ondergaan, omdat ze voor een levensbedreigende ziekte zijn opgenomen. In dergelijke omstandigheden is het volgens verpleegkundigen belangrijk dat patiënten zich zo veel als mogelijk is 'thuis' voelen.

Verpleegkundige: "Je probeert er eigenlijk voor te zorgen dat ze zich zo veel mogelijk thuis voelen. Ja, 'thuis' is natuurlijk een verkeerd woord."

\section{Een ander leven}

Door de opname op een afdeling, om behandeld te worden voor een levensbedreigende ziekte, zijn patiënten gedwongen een ander leven te leiden dan ze gewend waren. Verpleegkundigen signaleren problemen bij patiënten die daarmee samenhangen. Op verschillende manieren proberen verpleegkundigen ervoor te zorgen dat patiënten zich deze situatie meer eigen maken. 


\section{Een vertrouwde leefomgeving creéren}

Het ziekenhuis en de afdeling is voor veel patiënten vooral een onbekende omgeving. Lange gangen met dichte deuren. Een steriele kamer zonder versiering die ruikt naar ziekenhuis. Veel onbekende gezichten met onbekende functies en taken. Voor sommige patiënten is het opgenomen zijn in een dergelijk omgeving weinig problematisch. Andere patiënten kunnen zich echter ontheemd voelen, niet op hun plek of niet op hun gemak. Op verschillende manieren proberen verpleegkundigen dan iets aan deze situatie te veranderen. Ze vragen bijvoorbeeld aan patiënten of ze de kaarten die zij hebben gekregen voor hen zullen ophangen, of er foto's zijn van familie of vrienden die ze kunnen neerzetten of dat de gekregen bloemen zo staan dat patiënten ze goed kunnen zien. Verpleegkundigen proberen de leefruimte anders aan te kleden door er iets van de patiënt zelf aan toe te voegen.

Verpleegkundige: "We hebben haar nog eens verteld dat het mogelijk is spul-

len van thuis mee te brengen en ze te laten desinfecteren zodat ze toch de geisoleerde ruimte in mogen."

Verpleegkundigen proberen ervoor te zorgen dat patiënten zich een beetje thuis' voelen. De omgeving meer vertrouwd maken voor patiënten, kan volgens verpleegkundigen ook door patiënten inzicht te geven in het afdelingsgebeuren. Bij het opnamegesprek vertellen verpleegkundigen patiënten al het één en ander over de afdeling. Ze brengen hen op de hoogte van de afdelingsregels en routines: wanneer wordt gegeten, gerust of wanneer is het bezoekuur, zodat patiënten weten wat ze verwachten kunnen. Ze stellen patiënten ook op de hoogte van de regels zodat patiënten zich daaraan kunnen aanpassen, zodat ze bijvoorbeeld niet van de afdeling zijn als er eten wordt rondgebracht of als artsen visite lopen. Maar verpleegkundigen informeren patiënten ook om hen meer bekend te maken met de afdeling. Niet alle patienten voelen zich vreemd op de afdeling, maar er zijn patiënten die zich bijvoorbeeld erg overvallen voelen door de opname en die het overzicht kwijt zijn. Voor dergelijke patiënten herhalen verpleegkundigen de informatie over de afdeling regelmatig.

$\mathrm{lk}$ ben aanwezig bij het opname gesprek van Theo met meneer $\mathrm{x}$. De verpleegkundige geeft de patiënt onder andere allerlei informatie over de gang van zaken op de afdeling en wie er allemaal aan het bed kunnen komen. Later zegt Theo tegen mij dat het belangrijk is dat mensen weten hoe de dagindeling is. Voor verpleegkundigen is dat ook handig, dan hoeven ze niet steeds opnieuw van alles uit te leggen, of patiënten te zoeken wanneer ze ze nodig hebben. Voor patiënten zelf is het belangrijk dat ze weten wat en wieer allemaal is, zodat het allemaal wat meer bekend is. 


\section{Zinvolle tijdsbesteding bevorderen}

Patiënten zijn niet alleen in een vreemde omgeving, maar zijn ook nog eens losgesneden van de manier waarop ze gewoonlijk hun tijd doorbrengen. Patiënten hadden werk, huishoudelijke bezigheden, een tuin, een gezin, vrienden, hobby's. Nu zijn ze opgenomen in het ziekenhuis. Vaak ook nog eens voor langere tijd. Patiënten kunnen van verpleegkundigen zorg nodig hebben, om invulling te geven aan hun dagelijkse bezigheden. Vooral patienten die met een BMT geisoleerd verpleegd worden zijn zes tot acht weken 'opgesloten' op een kamer. Verpleegkundigen proberen er dan voor te zorgen dat de tijd die ze in het ziekenhuis moeten doorbrengen, toch nog zo aangenaam mogelijk voorbij gaat bijvoorbeeld door als 'tijdverdrijver' op te treden.

Verpleegkundige: "Ik voel me soms ook wel een tijdverdrijver, om het verblijf hier prettiger te maken. Het fijne is dat de mensen vaak tot verschillende leeftijdscategorieën horen, die dan overeenkomen met de mensen van het team. Je hebt mensen die ontzettend ziek zijn, die andere wensen hebben, waar je andere dingen voor kunt doen en voor kunt betekenen. Maar bij sommige patiënten voel ik me vaak meer zo'n speelkameraadje. Je zorgt ervoor dat de tijd sneller voorbij gaat en dat het verblijf wat aangenamer is."

Soms houden verpleegkundigen patiënten zelf bezig, om de tijd te vullen. Vaak echter hebben ze daar geen tijd voor. Een andere manier om patiënten te helpen de tijd door te komen, is door mee te denken of er geen activiteiten zijn die 'ze zouden kunnen uitvoeren, zoals lezen, handwerken, muziek luisteren of t.v. kijken of ze get?en hen adviezen over manieren waarop patiënten de dag door kunnen komen.

Petra praat met mevrouw x. 'Waar kijkt u graag naar op t.v.? Wat is uw favoriete programma?'. Petra praat met haar over t.v. kijken, boeken lezen, hobby's. Ze probeert te achterhalen wat deze mevrouw kan doen om de tijd door te komen. Ze vertelt ook over andere patiënten, over wat zij zoal doen. Petra vertelt over een meneer die aan het handwerken was geslagen op de afdeling. Deze mencer had dat nooit van zichzelf gedacht, maar hij bleek het erg leuk te vinden."

In het voorafgaande zijn zorgbehoeften van patiënten besproken die samenhangen met tijdsbesteding. In het denken en handelen van verpleegkundigen is zichtbaar dat ze er oog voor hebben dat patiënten verschillende behoeften hebben aan ondersteuning, om de tijd door te komen. Net als dit bij andere zorgbehoeften het geval is, is dit verschil afhankelijk van de patiënt als persoon. Patiënten hebben bijvoorbeeld verschillende interesses. Verpleegkundigen hebben er oog voor dat dergelijke interesses gedurende het opgenomen zijn kunnen veranderen, doordat patiënten zich in een nieuwe situatie bevinden. Zorgbehoeften kunnen ook verschillen omdat patiënten zich fysiek anders voelen. Verpleegkundigen hebben er oog voor dat behoef- 
ten van patiënten samenhangen met hun fysieke conditie. Als patiënten zich erg ziek voelen, dan is de vraag hoe de tijd door te komen minder aan de urde. Dan zijn patiënten zo beroerd dat ze nergens aan toe komen. Soms zijn patiënten vooral erg moe. Om de dag zo goed mogelijk door te komen, denken verpleegkundigen met patiënten mee over hoe ze hun energie zo goed mogelijk kunnen verdelen.

Wanneer Bea en ik bij mevrouw x binnenlopen ligt ze in bed. 'Weer in bed?' vraagt Bea. Mevrouw x zegt dat ze zich zo verschrikkelijk moe voelt dat ze nergens aan toe komt. Bea zegt dat dit ook logisch is omdat ze zich net gewassen en aangekleed heeft. 'Het is goed nu even uit te rusten en straks weer iets te doen. Je moet het een beetje verdelen', zegt ze. 'Iets doen en uitrusten'. 'En niet te streng zijn voor je zelf', zegt ze erachter aan. 'U denkt dat $u$ alles maar moet kunnen'.

\section{Normaliseren van vertrouwde contacten}

In het denken en handelen van verpleegkundigen is zichtbaar dat ze aandacht hebben voor behoeften van patiënten die samenhangen met hun contact met familie of andere vertrouwde mensen. Soms hebben patiënten ondersteuning nodig bij het instandhouden van dit contact, gedurende het proces van opgenomen zijn en behandeld worden voor een ernstige ziekte. De manier waarop patiënt en naasten thuis met elkaar omgingen staat onder druk door de context waarin ze zich samen bevinden. Patiënten en hun familie kunnen daar last van hebben. Dan proberen verpleegkundigen daar iets aan te doen. Bijvoorbeeld door een privé ruimte te creëren, waarin ze samen kunnen zijn. Verpleegkundigen hebben aandacht voor privacy van patiënten. Ze ergeren zich er bijvoorbeeld aan, wanneer collega verpleegkundigen of artsen vergeten een bedgordijn dicht te trekken of wanneer er een gesprek gevoerd wordt dat door derden te horen is en waarin intieme informatie naar voren komt.

Verpleegkundige: "Waar ik me dood aan erger is als mensen een gordijn niet dichttrekken. Dat moet je gewoon doen. Ook al verwissel je even snel een pyjama jasje."

Verpleegkundige: "Ik heb wel eens een arts van de kamer afgehaald en gezegd 'zou je met die meneer over zijn incontinentie niet ergens anders praten'.

Hij deed dus de opname op de kamer waar andere patiënten bij lagen die fijn aan het meeluisteren waren."

Rekening houden met privacy van patiënten heeft in het denken en handelen van verpleegkundigen nog een andere betekenis. Ze houden daar rekening mee, omdat patiënten daar behoefte aan kunnen hebben in het kader van hun contacten met familie of andere relevante anderen. Een privé-omgeving kan er dan toe bijdragen dat vertrouwelijk contact wordt bevorderd. Daarom zou- 
den verpleegkundigen bij patiënten die alleen op een kamer liggen kunnen kloppen.

Verpleegkundige: "Wat me altijd verbaast bij verpleegkundigen is dat ze zo een kamer kunnen binnen stormen bij patiënten. Patiënten die geïsoleerd verpleegd worden zeker. Ik had daar in het begin altijd veel moeite mee. Je betreedt toch hun domein. Nu betrap ik me erop dat ik ook soms zo maar naar binnen stap, zonder te kloppen. Op een meer-persoonskamer al helemaal. Dan hebben mensen helemaal geen privacy eigenlijk. Dat is soms heel vervelend voor ze. Ook als er een partner is, ja dan kun je toch vaak niet met elkaar omgaan zoals je dat zou willen."

Verpleegkundige: "Mevrouw $\mathrm{x}$ gaf aan dat ze vond dat we te weinig aandacht hadden voor haar contact met haar man. Zij had er behoefte aan met haar man samen te zijn zonder dat verpleegkundigen voortdurend in en uit liepen. We moeten dat toch nog eens bespreken in het team. Hoe we meer ruimte kunnen maken voor contact met partners."

Een andere manier om contact tussen familie te normaliseren is door hen advies te geven over hoe ze weer eens 'echt samen' kunnen zijn.

Verpleegkundige: Haar echtgenoot was er iedere dag van een uur of drie tot 's avonds een uur of negen. Dat vond zij heel erg fijn. Toen heb ik gezegd van 'goh, wat vind je ervan als je man in de hal een crème of zalf gaat halen zodat je nadat je onder de douche bent geweest eens even lekker wordt ingesmeerd door je man'. Tegen haar man zei ik 'dan voel je haar ook eens even, dan heb je echt weer het contact, je strijkt haar over haar hele lijf en ze ruikt weer lekker'. Nou, dat hebben ze dus gedaan. Hij is die crème gaan halen en heeft haar ingesmeerd. Dat vonden ze allebei zalig. Ze hadden het gevoel dat ze samen waren. En niet zo dat zij als zieke patiënt in een bed lag en hij op een stoel ernaast. Nee, ze waren met $z$ 'n tweeën en dat vonden ze fijn. Zie je, dat helpt toch."

Een volgende manier om het contact tussen patiënt en naasten te normaliseren is door hen informatie te geven over ziekte en behandeling. Het contact kan bijvoorbeeld verstoord zijn, omdat familie geen zicht heeft op het ziekte proces en de behandeling. Dat is soms het geval wanneer patiënten geïsoleerd verpleegd worden in een steriele omgeving. Familie en patiënt kunnen dan. als het ware bang zijn om elkaar aan te raken. Verpleegkundigen proberen door het geven van informatie over ziekte en behandeling, de verhouding tussen familieleden in dergelijke omstandigheden te normaliseren.

Verpleegkundige: "Samen zijn is voor mensen die zo ziek zijn heel moeilijk. Zeker als ze de eerste keer bij ons zijn en dan chemo krijgen en als ze dan in die dip zijn (lage bloedcellen met als gevolg weinig weerstand). Dan moeten de deuren dicht (isolatie), je moet steeds de handen wassen als je daar naar binnen gaat, en ze kriigen bacterie-arm eten (om infecties te voorkomen). En 
ja, die familie is dan zo ontzettend bang om ze aan te raken. Ze denken dan dat ze 'vies' zijn en ze zouden dan wel eens 'enge beesten' naar binnen kunnen brengen. En ja, dan raken ze die mens niet aan en dan moet je echt zeggen van 'goh, je mag ze best een zoen geven of eens een knuffel geven of zo'."

\section{Aandacht voor een verloren identiteit}

Wanneer patiënten zijn opgenomen in het ziekenhuis, kunnen ze volgens verpleegkundigen soms het gevoel hebben dat ze niet meer als mens geziın worden. Wat verpleegkundigen dan proberen te doen is hen het gevoel geven dat $z i j$ de mens zien achter de patiënt.

Verplegkundige: "Wat wij vaak doen is patiënten toch het gevoel geven dat ze niet één van de velen zijn, maar dat het om hén gaat."

Niet alleen voelen patiënten zich volgens verpleegkundigen "één van de velen', ze voelen zich soms ook meer ziekte dan mens. Verpleegkundigen herinneren collega's en andere zorgverleners eraan dat daar een mens in bed ligt.

Verpleegkundige: "Ook naar artsen toe. Soms hebben wij het gevoel dat ze alleen nog maar een ziekte zien. Wij herinneren hen er dan aan dat het een mens is dat daar in bed ligt."

Verpleegkundige: "Dat zeg ik ook wel eens tegen collega's, je kent dat wel, 'dit is geen arm of been dat daar ligt' of, zoals bij ons 'de ziekte kanker'. Je ziet ook wel eens collega's die over de patiënt heen praten over het weekend, dan zeg ik daar ook wat van 'laat meneer x eens meepraten dames'."

\section{Verloren zeggenschap over de eigen situatie}

Patiënten die in het ziekenhuis zijn opgenomen kunnen volgens verpleegkundigen soms het gevoel hebben een speelbal te zijn van krachten waar ze geen invloed op uit kunnen oefenen. Niet alle patiënten hebben daar last van, maar sommige patiënten willen enige invloed uitoefenen op hun eigen leven binnen de muren van het ziekenhuis.

\section{Zeggenschap over de eigen situatie bevorderen}

Zoals in paragraaf $2 . r$ is besproken geven verpleegkundigen patiënten informatie over de afdeling en instelling, onder andere om de omgeving meer vertrouwd te maken. Tegelijkertijd verstrekken verpleegkundigen aan patiënten informatie over het reilen en zeilen van de afdeling, om hen de mogelijkheid te bieden tijd naar eigen inzicht te benutten. Wanneer patiënten weten wat er, voor welk moment op het programma staat, kunnen ze zich daarop instellen en bij het invullen van hun dag daarmee rekening houden. Ze kunnen deze activiteiten zelf kiezen en ervan uitgaan dat ze bij het verrichten ervan waarschijnlijk niet gestoord worden. 
Verpleegkundige: "Kijk, het is prettig als mensen weten wat er gaat gebeuren en wat de mogelijkheden zijn. Wanneer bezoek kan komen, wanneer er gegeten wordt. Dan kunnen ze daar rekening mee houden, worden ze minder overvallen."

Verpleegkundige: "Wanneer je weet dat er een periode is dat er geen temp wordt gemeten, bloeddruk, weet ik wat, bloed geprikt, dan kun je eens even de tijd nemen je partner te bellen, zonder dat je steeds gestoord wordt."

Sommige patiënten hebben door de opname het gevoel dat ze geen enkele invloed meer op hun leven hebben en hebben daar last van. Door inzicht te geven in de regels en routines van de afdeling, trachten verpleegkundigen het gevoel bij patiënten te verminderen dat hun leven door anderen wordt overgenomen. Een andere manier waarop verpleegkundigen proberen tegemoet te komen aan behoeften die ze bij sommige patiënten signaleren om zeggenschap over hun leven te houden, is hen op de hoogte te brengen van faciliteiten van de afdeling en de instelling. Als patiënten weten wat de mogelijkheden zijn, kunnen ze deze ook benutten. Wanneer patiënten of hun familie bijvoorbeeld weten dat er een maatschappelijk werkster verbonden is aan de afdeling, kunnen ze zelf het initiatief nemen deze te consulteren.

Verplirgkundige: "Zijn vrouw had het heel erg moeilijk met de situatie. We hebben haar toen verteld dat er een maatschappelijk werkster was op de afdeling, zodat ze daar gebruik van kon maken als ze dat wilde."

Verpleegkundigen geven patiënten informatie over de aanwezigheid van hulpverleners binnen de instelling. Ze wijzen hen ook op faciliteiten zoals de bibliotheek binnen de instelling, zodat ze kunnen kiezen of ze een boek willen lenen.

In deze paragraaf zijn zorgbehoeften besproken die samenhangen met het feit dat patiënten opgenomen zijn op een afdeling in een ziekenhuis, weg van de vertrouwde omgeving en weg van thuis. Patiënten zijn daardoor gedwongen een andere leven te leiden, hun tijd anders door te brengen of anders met vertrouwde naasten om te gaan. Verpleegkundigen ondersteunen patiënten die zich in deze omstandigheden bevinden, om ervoor te zorgen dat de tijd - ondanks deze situatie - zo aangenaam mogelijk voorbij gaat. Patienten kunnen ook het gevoel hebben dat ze geen zeggenschap meer hebben over hun eigen situatie. Dat hun leven als het ware van hen wordt overgenomen. Verpleegkundigen proberen patiënten die dat zo ervaren, te helpen meer grip te krijgen op hun situatie door hen bijvoorbeeld over de regels en routines van de afdeling en instelling te informeren of door hen op de hoogte te brengen van allerlei faciliteiten waar ze gebruik van kunnen maken. 


\section{EEN LEVENSBEDREIGENDE ZIEKTE}

Patiënten van afdeling Io hebben kanker. Ze worden daardoor met de eindigheid van het leven geconfronteerd. Deze confrontatie kan volgens verpleegkundigen verschillende behoeften aan zorg met zich meebrengen.

\section{Eindigheid van het leven}

De prognose voor patiënten met kanker is voor verschillende vormen zeer verschillend. Voor patiënten die zijn opgenomen voor de ziekte van NonHodgkin is definitieve genezing bij ontdekking in stadium I meestal mogelijk. Wanneer de ziekte in één van de daar op volgende stadia wordt ontdekt is het verloop betrekkelijk langzaam en goedaardig, maar volledige genezing is meestal niet meer mogelijk. Voor de ziekte van Hodgkin geldt dat tegenwoordig vaak met succes behandeld kan worden. Vooral bij tijdige ontdekking (stadium I en II). Bij latere signalering wordt deze kans steeds kleiner. Voor patiënten met leukemie en mamma carcinoom geldt dat de kans op genezing is toegenomen, maar dat patiënten regelmatig de zeer zware behandeling niet overleven. Bij de ziekte van Kahler is bij tijdige ontdekking een redelijk goede beheersing van de ziekte mogelijk. Bij latere ontdekking is dat minder het geval.

Hoewel de verschillende vormen van kanker een verschillende prognose hebben, brengt het hebben van een levensbedreigende ziekte voor veel patiënten hoe dan ook een moeilijke confrontatie met de eindigheid van het bestaan met zich mee.

Verpleegkundige: "Het gros van de patiënten, meer dan de helft, wordt dus niet meer beter. Bovendien worden de patiënten nog eens extra ziek gemaakt met het vooruitzicht dat ze zich misschien beter gaan voelen, maar ook de kans dat ze er dood aan gaan. Oncologische patiënten moeten vijf jaar aftellen voor ze kunnen zeggen 'het is goed, nu kan ik zeggen ik ben gezond verklaard'. En dan durven ze het vaak nog niet."

Verpleegkundige: "Ik bedoel die mensen gaan misschien wel dood, wat gaat er dan niet allemaal door je heen."

Een levensbedreigende ziekte confronteert patiënten met de eindigheid van het leven. Dat is voor veel patiënten niet gemakkelijk. Afhankelijk van de persoon die ze zijn en de situatie waarin ze zich bevinden hebben ze behoefte aan zorg, om dit besef van de dood draaglijker te maken. In het vervolg van deze paragraaf wordt ingegaan op behoeften die verpleegkundigen bij patiënten signaleren en die van doen hebben met emotionele pijn en lijden. Ook komen behoeften van patiënten aan de orde die samenhangen met hun relatie met familie. 


\section{Emotionele pijn en lijden}

Wanneer patiënten aan de behandeling beginnen, is het mogelijk dat ze deze behandeling niet zullen overleven. Deze situatie brengt voor veel patiënten emotionele pijn en lijden met zich mee. Dat kan zich volgens verpleegkundigen op verschillende manieren manifesteren. Veel patiënten zijn bijvoorbeeld angstig en onzeker gedurende het hele proces van behandeld worden voor een levensbedreigende aandoening.

Verpleegkundige: "Bij opname weet je dat er vaak spanning is. De gestelde diagnose en de angst voor het onbekende. Gedurende het hele proces is er die angst om de ziekte onder ogen te zien, wat er kan gebeuren."

In het denken en handelen van verpleegkundigen is zichtbaar dat ze oog hebben voor gevoelens van angst, ongerustheid en onzekerheid van patiënten die veelal gedurende de hele opname een rol spelen. Angst voor het onbekende, angst voor pijn, angst voor dat ene onderzoek, bang dat de behandeling niet aanslaat, angst voor de dood. Patiënten van afdeling ro kunnen lijden aan het leven dat ze op dat moment gedwongen zijn te leven, omdat het een leven is vol angst en onzekerheid. In het denken en handelen van verpleegkundigen is zichtbaar dat ze daarnaast oog hebben voor allerlei andere gevoelens, die samen kunnen hangen met een confrontatie met de eindigheid van het bestaan. Sommige patiënten schamen zich bijvoorbeeld voor de aftakeling van hun lichaam.

Verpleegkundige: "Ernstig vermageren, geïnfecteerde mond, haar uitval. Patiënten kunnen schrikken van zichzelf. Schamen zich soms ook voor hoe ze eruit zien. Dan zeg je bijvoorbeeld 'trek die leuke pyjama aan' of 'denk eens aan een sjaal om je hoofd'. Dat soort dingen. Is niet veel, maar toch." Soms kunnen patiënten zich schuldig voelen. Schuldig dat ze ziek zijn. Schuldig dat ze niet meer voor hun familie kunnen zorgen. Schuldig dat ze dood gaan.

Verpleegkundige: "Patiënten kunnen zich soms heel schuldig voelen, om van alles en nog wat. Ziek zijn, opgenomen zijn, van alles."

Verpleegkundige: "Die mevrouw, die verontschuldigde zich de hele tijd door. Dat ze ziek was. Dat ze voor een onderzoek weg moest. Die verontschuldigde zich nog dat ze dood ging! Daar hebben we dus wat aan geprobeerd te doen. Gezegd 'probeer toch eens aan u zelf te denken. $U$ denkt alleen aan anderen. Denk toch eens aan u zelf."

Patiënten reageren steeds weer anders op de situatie waarin ze zich bevinden. Sommige patiënten hebben bijvoorbeeld veel steun van familie of vinden steun in het geloof. Andere patiënten hebben meer aandacht van verpleegkundigen nodig, om de situatie te kunnen verdragen. 


\section{Gelegenheid bieden het eigen verhaal vertellen}

Patiënten die met een levensbedreigende ziekte worden geconfronteerd en emotioneel pijn lijden, hebben er volgens verpleegkundigen vaak behoefte aan hun eigen verhaal te vertellen. Op verschillende manieren proberen verpleegkundigen patiënten de gelegenheid te geven dit verhaal te vertellen.

Verpleegkundigen stimuleren patiënten om te praten, bijvoorbeeld met hun partner, kinderen of andere belangrijke mensen in hun leven. Of verpleegkundigen stimuleren patiënten met hun arts te praten of met andere zorgverleners. Daarnaast praten verpleegkundigen ook vaak zelf met patiënten. Regelmatig gebeurt dat tussen de bedrijven door. Tijdens het wassen, bed opmaken, wondverzorging of medicatie toedienen wordt er gepraat. Soms ook gaan verpleegkundigen daar expliciet voor zitten, wanneer ze merken dat patiënten daar behoefte aan hebben.

Verpleegkundige: "Ik denk dat je bij mensen die heel ziek zijn heel behulpzaam kan zijn in hun dagelijkse verzorging en hun dagelijkse dingen, maar ook emotioneel steun kan bieden in het verwerken van hun ziekte en het bespreekbaar maken daarvan."

Verpleegkundige: "En dan gooi ik eens een balletje op en dan kijk ik hoe ze reageren, om te zien waar ze mee bezig zijn of ze behoeften hebben om te pridten."

Een andere manier waarop verpleegkundigen patiënten stimuleren hun verhaal te vertellen is door hen expliciet te laten zien dat ze het specifieke verhaal van de patiënt horen en begrijpen. Het gaat er volgens verpleegkundigen om, aan patiënten te laten zien dat er écht geluisterd wordt naar het eigen verhaal van patiënten en om patiënten te laten zien dat dit ook wordt gehoord.

Verpleegkundige: "Belangrijk is dat je echt luistert, écht luistert niet zo van 'oh,

dat heb ik ook of dat had die en die ook', daar hebben patiënten niets aan." Ondanks het feit dat verpleegkundigen dagelijks zorgen voor patiënten die geconfronteerd worden met de eindigheid van het bestaan, hebben ze er oog voor dat het voor deze patiënt een unieke en ingrijpende gebeurtenis is en dat ze deze patiënt de ruimte moeten geven hun eigen persoonlijke verhaal te beleven en vertellen. Het gaat erom dát verhaal te horen en te begrijpen. Eenn volgende manier waarop verpleegkundigen trachten tegemoet te komen aan behoeften van patiënten hun verhaal te vertellen om fysieke pijn en lijden te verminderen, is door zelf als persoon betrokken te raken. Wanneer verpleegkundigen proberen patiënten hun verhaal te laten vertellen, kan dat volgens hen niet zonder daar zelf als mens in te investeren.

Verpleegkundige: "Als je dan met iemand gepraat hebt over hoe het voelt om dood te gaan, dan voel ik me als mens geraakt. Dat kan ook niet anders. Hoe zou dat anders moeten?" 
Wanneer patiënten geconfronteerd worden met emotionele pijn en lijden dan denken verpleegkundigen dat betrokkenheid en nabijheid van hun kant haast onontbeerlijk is.

Verpleegkundige: "Ik denk dat als je emotie voelt bij je werk, dat dat juist een teken is dat je goede zorg verleent. Ik denk als je op oncologie werkt en je werkt zonder emotie, dat dat niet goed is. Ik denk dat je, als je laat zien dat je met gevoel werkt, dat je dan ook een betere band met een patiënt kunt krijgen. Als je afstandelijk zorg verleent krijg je ook veel minder reactie van een patiënt. Dat een patiënt zich moeilijker kan uiten. Je moet dat niet gaan forceren van 'ik moet nu emotioneel zijn, want dan krijg ik meer uit een patiënt', zo werkt dat ook weer niet. Maar ik denk niet dat het erg is als jee een wat emotionelere relatie hebt met een patiënt, integendeel."

In het denken en handelen van verpleegkundigen is zichtbaar dat ze ervan uitgaan dat zij zich ook in een positie bevinden om een band met een patiënt aan te gaan en dat ze emotioneel betrokken kunnen raken om patiënten in de gelegenheid te stellen hun eigen verhaal te vertellen. Soms vervult familie ook een dergelijke rol. Zij steunen patiënten bij het verwerken van de ziekte en het omgaan met bijvoorbeeld angst en onzekerheid. Bovendien zijn ook artsen betrokken bij patiënten, en ondersteunen hen in het hele ziekte proces. Verpleegkundigen zien echter een belangrijke rol voor zichzelf weggelegd, omdat ze veel tijd met patiënten doorbrengen. Zij zijn-als groep-24 uur per etmaal aanwezig. Bovendien gaan verpleegkundigen ervan uit dat ze in een positie zijn betrokken te raken door het type zorg dat zij aan patiënten geven. Verpleegkundigen geven vaak intieme zorg aan patiënten. Ze wassen hun zieke lichaam en kleden het aan, wanneer een patiënt daar zelf niet toe in staat is. Verpleegkundigen houden het bekken vast, als een patiënt moet braken en vegen hun mond af of verschonen het bed. Verpleegkundigen legen de po, wanneer een patiënt niet meer uit bed kan komen om naar toilet te gaan. Door de aard van het contact tussen verpleegkundige en patiënt en de zorg die verpleegkundigen aan hen geven, gaan ze ervan uit dat zij in staat zijn betrokken te raken bij het proces dat patienten doormaken.

Verpleegkundige: "Wij staan toch het meeste bij patiënten. Veel meer dan artsen. Die zijn natuurlijk ook betrokken. Maar wij zien patiënten toch veel vaker en veel meer en in andere omstandigheden. Ik bedoel wij slepen met hun poep en pies. Ik bedoel maar. Dan maak je toch wat mee samen. Dan staan wij er toch het dichts bij. Je maakt veel mee samen."

\section{Stimuleren tot reflectie}

Verpleegkundigen gaan ervan uit dat er patiënten zijn, die behoefte hebben aan reflectie op dat eigen verhaal. Patiënten die bijvoorbeeld vastgelopen zijn in hun emotionele pijn en daar zelf niets aan kunnen veranderen. Op ver- 
schillende manieren proberen verpleegkundigen voor dergelijke patiënten te zorgen. Verpleegkundigen geven soms positieve feedback aan patiënten. $\mathrm{Ze}$ vertellen patiënten bijvoorbeeld dat ze zich niet hoeven te schamen voor hun emoties of dat ze het goed doen.

Verpleegkundige: "Iemand het gevoel geven dat hij mag huilen. Dat hij zich niet hoeft te schamen."

Tijdens de overdracht zegt Ineke over mevrouw $\mathrm{x}$ : "Deze mevrouw heeft veel aandacht nodig. Ze is ontzettend onzeker. Bang ook natuurlijk. Maar vooral onzeker. We moeten zorgen dat ze wat meer vertrouwen krijgt, in ons, maar ook in zichzelf.

Ik loop vandaag met Bea mee. Ze praat met mevrouw x. Bea zegt haar dat ze vindt dat ze zo dapper is. Dat ze het zo goed volhoudt. Dat ze de moed er zo goed in kan houden. Ze zegt dat ze zich afvraagt of zij dat zelf wel zou kunnen. Bij andere patiënten reflecteren verpleegkundigen op hun situatie, door hen te confronteren met de manier waarop ze met het ziek zijn omgaan. Volgens verpleegkundigen zijn er patiënten voor wie de situatie moeilijk te verdragen is, omdat ze niet kunnen omgaan met het feit dat ze ziek zijn.

Verpleegkundige: "Wat bij die mevrouw ook heel erg speelde is dat ze zich steeds verontschuldigt. Om te beginnen al voor haar dik zijn. Maar ze verontschuldigde zich voor alles. Iedere vraag die ze stelde, alles wat je deed, voor alles eigenlijk wat ze gewoon nodig had. En daar wilde ik ook graag iets aan doen. Dat is gewoon de aard van de persoon natuurlijk. Maar ik dacht 'als u zo begint met u te verontschuldigen, ja waar blijf je dan? Dadelijk verontschuldigt u zich nog voor het feit dat $\mathrm{u}$ leukemie heeft'. Daar ben ik een stukje confronterend in geweest. Het valt me op dat u zich voor alles verontschuldigt. Waarom is dat eigenlijk zo? En toen zei ze 'dat is inderdaad ook zo, dat zeggen meer mensen tegen me, maar ja zo ben ik nu eenmaal. En ik weet dat ik nu eigenlijk aan mezelf moet gaan denken'. Stukje bij beetje pakte ze dat wel op. Ik denk dat die confrontatie haar iets opgeleverd heeft. Ja, gedurende deze behandelingskuur wel. Om dit hanteerbaar te maken. Voor waar ze mee bezig is wel. Ik denk niet qua persoonlijkheid. Het zal iemand zijn die zich blijft verontschuldigen. En eigenlijk uit zorgzaamheid voor anderen zichzelf op een andere, op de laatste plaats zetten, zeg maar. Aan een persoonlijkheid an sich verander je niets. Alleen om het voor haar hanteerl)dar te maken. Want ja, als jij continue met je gedachten bij je kinderen bent, van 'god, moeten de kinderen iedere dag helemaal naar me toe komen, dat kan ik toch niet maken, ze moeten van zo ver komen, nee, dat kan ik echt niet maken, en dan moet ik ook nog weg voor onderzoek, o nee'. Ze was alleen daar mee bezig. Meer bezig met haar echtgenoot en kinderen dan met zichzelf. Zelf kwam helemaal niet aan rust toe. Druk bezig met: telefoontjes aannemen van familieleden; kennissen informeren; klaar staan voor de familie; en ik 
moet er toch goed bijzitten als er bezoek komt; en dan moet ik vrolijk zijn; ik moet praten want mensen komen speciaal voor mij op bezoek; dus ik moet wel vertellen hoe het met me gaat. En's nachts slaapt ze bijvoorbeeld niet."

Door patiënten te confronteren met de manier waarop ze met hun ziekte omgaan, gaan verpleegkundigen ervan uit dat ze gemakkelijker door het hele proces van ziek zijn, behandeld worden en opgenomen zijn heenkomen. Het gaat er niet om patiënten als persoon te veranderen, dat is niet het doel van de confrontatie. Waar het om gaat is patiënten te laten zien hoe ze met hun situatie omgaan en daardoor de situatie zo acceptabel mogelijk voor hen te maken. Soms confronteren verpleegkundigen patiënten met hun eigen gedrag, wanneer ze zien dat de situatie voor deze patiënten moeilijk te verdragen is omdat ze hun eigen situatie niet onder ogen durven zien.

Verpleegkundige: "Dit is een meneer die haast ontkent dat hij kanker heeft. Die kan daar niet bij stil staan. Ik vroeg gisteren aan hem wat de dokter had verteld en dan zegt hij 'oh, de dokter zegt dat ik over zes weken gezond weer thuis ben'. Nu was ik er niet bij, maar ik weet zeker dat de dokter $x$ dat niet heeft gezegd. Zo doet hij dat niet. Dus ik probeerde voorzichtig eens te praten, maar dat pikt hij niet op. Dat gaat nog moeilijk worden voor die man."

Verpleegkundigen confronteren patiënten soms met hun gedrag, wanneer ze denken dat patiënten als het ware last van zichzelf hebben, waardoor de situatie moeilijk te verdragen is.

\section{Emotionele troost bieden}

In het denken en handelen van verpleegkundigen is zichtbaar dat ze er oog voor hebben dat patiënten niet altijd behoefte hebben om te praten, maar soms behoefte hebben aan emotionele troost om de situatie als minder ernstig te ervaren. Verpleegkundigen bieden patiënten troost door hen bijvoorbeeld hoop te geven.

Verpleegkundige: "Soms praat je ook met patiënten mee. Ik zal nooit zeggen van 'dan bent $\mathrm{u}$ allang thuis, als $\mathrm{u}$ kleindochter de communie doet'. Dat zal ik nooit zeggen. Sommigen doen dat. Laatst hoorde ik dat de dokter nog zeggen tegen haar. Dat zal ik niet snel doen. Al wil je dat natuurlijk wel graag tegen die mensen zeggen. Dat zal ik toch niet doen, omdat - als patięnten dan niet dan en dan thuis zijn - de teleurstelling nog veel groter is en ze helemaal denken dat ze nooit meer thuis komen. Maar ik praat soms wel eens mee met patiënten als ze het hebben over toekomst plannen of als ze zeggen dat ze zeker weten dat ze beter worden."

Een andere manier van emotioneel troosten die in het denken en handelen van verpleegkundigen zichtbaar is, is dat ze patiënten soms afleiden. Soms hebben patiënten genoeg gepraat en gepiekerd en is het tijd om te lachen. 
Verpleegkundige: "Jc moet ook eens met patiënten kunnen lachen. Zorgen dat ze ook eens ergens anders aan denken."

Verpleegkundige: "Wat ik zou willen is dat mensen, ondanks wat ze hebben, toch nog een beetje een goede tijd hebben gehad hier. Dat we ook nog eens hebben kunnen lachen samen. Dat is ook belangrijk voor deze mensen. Het is allemaal al zo zwaar. Soms moet je ook eens met wat anders bezig zijn."

De veronderstelling van deze verpleegkundige is, dat een voortdurende confrontatie met de eindigheid van het leven, de situatie voor patiënten nog veel zwaarder kan maken en in die zin ook nieuwe zorgbehoeften kan creëren. Soms zijn er zelfs patiënten die helemaal geobsedeerd zijn door angst voor de dood en die nergens anders over kunnen denken. Dan kiezen verpleegkundigen er bewust voor met deze patiënt niet te praten over ervaringen met het ziek zijn.

Verpleegkundige: “Dat was bij x ook het geval. Ze was heel angstig op het moment dat ze binnen kwam. Verschrikkelijk angstig. Je zag dat ze in het begin eigenlijk continue haar eigen begrafenis voor zich zag. Uiteindelijk is ze ook overleden. In de beginfase zijn we heel veel op die angsten ingegaan en heb ik geprobeerd haar gerust te stellen. Maar we hebben ook, ik heb ook geprobeerd haar op andere gedachten te brengen. Bewust over haar angst heen te stappen. Proberen de zaak wat luchtiger te maken. Proberen er niet meer over te praten."

Andere patiënten kunnen behoefte hebben aan kennis over ziekte en behandeling, om een situatie waarin ze emotioneel lijden voor hen acceptabeler te maken. In de vorige paragraaf is aan de orde gekomen dat patiënten soms informatie nodig hebben, om zeggenschap te behouden over hun lichaam. Voor andere patiënten is dat niet het geval. Informatie is voor hen juist heel belastend, omdat het hen angstig en onzeker maakt. Wanneer gekeken wordt naar de manier waarop verpleegkundigen proberen emotioneel lijden van patiënten te verminderen, dan wordt zichtbaar dat ze patiënten echter juist soms weer informatie geven om angst te beteugelen, omdat deze houvast biedt. Welke informatie een patiënt wanneer nodig heeft, zodat deze de situatie zo goed mogelijk kan verdragen, is daarmee een ingewikkelde aangelegenheid. In het volgende hoofdstuk worden dergelijke situaties, waarin niet duidelijk is wat een patiënt nodig heeft om zo goed mogelijk met het behandeld worden en opgenomen zijn voor een levensbedreigende ziekte heen te komen, verder uitgewerkt.

\section{Een compagnon zijn}

In het voorafgaande is beschreven dat verpleegkundigen er oog voor hebben dat patiënten emotioneel lijden door een confrontatie met de eindigheid van het bestaan. Deze pijn kan zich volgens verpleegkundigen op verschillende manieren manifesteren. Patiënten kunnen angstig of onzeker zijn, maar zich 
ook schuldig voelen of zich schamen. In het denken en handelen van verpleegkundigen is zichtbaar dat ze zien dat patiënten in die omstandigheden behoefte kunnen hebben aan een compagnon. Verpleegkundigen tonen zich daarom betrokken bij patiënten gedurende het proces dat ze doormaken.

Verpleegkundige: "je moet met hén bezig zijn, met hen meegaan, zoals zij daar mee bezig zijn."

Verpleegkundige: "Belangrijk is erbij te blijven, met hen mee te gaan in dat hele proces."

Verpleegkundigen gaan ervan uit dat voor patiënten de situatie draaglijker wordt, wanneer ze het gevoel hebben er niet alleen in te staan, maar dat iemand bij hen blijft en met hen meegaat in het hele proces. Een dergelijke behoefte is ook in paragraaf $\mathrm{r}$ beschreven. Daar is aan de orde gekomen dat patiënten soms behoefte hebben aan een compagnon om grip te krijgen op hun eigen situatie. Patiënten krijgen allerlei behandelingen en onderzoeken, dan is het fijn als ze het gevoel hebben dat iemand met hen meedenkt en de situatie met hen of voor hen in de gaten houdt. Een dergelijke behoefte aan een compagnon heeft niet alleen te maken met het zicht op behandelingen en onderzoeken, maar ook met het verlichten van emotionele pijn of om rustig te worden.

\section{Samen 'ziek'}

In het voorafgaande is met name de patiënt als persoon besproken. In het denken en handelen van verpleegkundigen is zichtbaar dat ze daarnaast ook aandacht hebben voor de relaties rondom de patiënt: het gezin, familie of andere mensen die de patiënt na staan. Verpleegkundigen besteden hier ook aandacht aan omdat deze ook behoeften kunnen aan zorg. Verpleegkundigen gaan ervan uit dat deze naasten van invloed zijn op ervaringen van de patiënten. Patiënten zijn niet alléén ziek. Een levensbedreigende ziekte heeft impact op een heel gezin of familie. Patiënten maken zich vaak zorgen over familie die ze achterlaten omdat ze in het ziekenhuis zijn opgenomen.

Verpleegkundige: "Iedere patiënt is bijzonder. Iedere patiënt is een persoon met een baan, een gezin, met een familie en met een verleden en met een toekomst misschien nog. Een patiënt heeft een eigen leven. Het is belangrijk dat je dat ziet. Niet alleen dat kleine stukje, maar ook dat stuk erom heen. Dat vind ik heel belangrijk om dat te blijven zien."

Patiënten hebben veel tijd om te piekeren. Eén van de zaken die hen daarbij vaak bezig houdt is de vraag of familie het allemaal wel redt. In die zin hebben patiënten er ook behoefte aan dat er voor hun familie wordt gezorgd. Ze voelen zich geruster als die er niet alleen voorstaat. 
Hanny praat met mevrouw $\mathrm{x}$. Ze maakt zich zorgen over thuis. Haar oudste dochter van 18 doet nu het meeste van de huishouding. Ze maakt zich zorgen over de vraag of die wel weet hoe ze aardappelen moet koken. Hanny praat met haar. Vertelt haar over haar dochters. Wat die allemaal konden op die leeftijd. Hanny probeert haar gerust te stellen.

\section{Steun geven aan familie}

Verpleegkundigen hebben ook oog voor zorgbehoeften van familie van patiënten. Niet alleen omdat ze met deze behoeften van familieleden - die veelal regelmatig aanwezig zijn rondom de patiënt - worden geconfronteerd, maar ook omdat patiënten zich vaak zorgen maken om hun naasten. Verpleegkundigen geven familie daarom soms praktische steun. Ze denken met hen mee of geven advies bij het zoeken naar oplossingen voor praktische problemen die veroorzaakt worden doordat de patiënt uit het gezin is weggevallen. Ze geven tips in verband met zorg voor kinderen, contacten met het werk, financiële ondersteuning voor kosten, ed.

Verpleegkundige: "Die mensen krijgen dat zelf niet geregeld en ze hebben maar heel weinig geld. Haar man weet niet of hij iedere dag kan komen, omdat hij de reiskosten niet kan betalen. Hoe zullen we dat aanpakken? Misschien moeten we de maatschappelijk werkster vragen eens met hen te praten. Die kan het financiële totaalplaatje bekijken." Voor patiënten kan het belangrijk zijn dat ze het gevoel hebben dat hun familie er niet alleen voorstaat, en dat deze geholpen wordt bij het draaiende houden van de nieuwe situatie.

Patiënten maken zich vaak ook zorgen over de manier waarop familie omgaat met het feit dat éen van hen met een levensbedreigende ziekte is geconfronteerd. Verpleegkundigen praten daarom ook vaak met hen. Ze bieden familie emotionele steun. Familie is vaak net zo bang, ongerust en onzeker als patiënten zelf.

Mia praat met de man van mevrouw $x$. Het gaat helemaal niet goed met zijn vrouw. Ze voelt zich niet goed maar de artsen kunnen er niet achter komen. wat er aan de hand is. Meneer kornt elke dag. Mia vraagt hoe het met hem. gaat. Hij zegt dat hij het heel zwaar vindt. Hij maakt zich ernstig zorgen. Hij heeft er helemaal geen goed gevoel over. Bereidt zich voor op het ergste. Mia probeert hem een beetje gerust te stellen. Niet te ver vooruitlopen. Hij zegt dat hij dat probeert, maar dat lukt niet altijd."

\section{Ondersteunen van de relatie}

In het denken en handelen van verpleegkundigen is zichtbaar dat ze aandacht hebben voor de relatie tussen de patiënt en zijn of haar belangrijkste naasten. Deze relatie kan verstoord raken, omdat ze als het ware samen ziek zijn. Soms 
kunnen patiënten en hun naasten last hebben van de manier waarop ze met elkaar omgaan. Verpleegkundigen proberen de verhouding tussen patiënten en hun naasten dan te verbeteren door bijvoorbeeld de onderlinge communicatie te vervorderen. Zoals in een situatie waarin een partner het naderende sterven van zijn echtgenote niet kan aanvaarden.

Verpleegkundige: "Dat was een mevrouw, die was aan het sterven, maar haar man had dat niet aanvaard. Zij wilde eigenlijk sterven. En zij zei op een gegeven moment 'ik ga dood, ik ga echt dood' en ze wilde ook dood. En haar man zei van 'nee, je gaat niet dood'. En een uur er na was ze dood. Maar gewoon die strijd die ze met elkaar hebben geleverd. Dat einde eigenlijk niet goed kunnen afmaken. Daar heb ik best moeite mee. Want ja, je kan wel bijsturen, maar op een gegeven moment sta je daar ook machteloos tegenover. Want zij moeten het uiteindelijk zelf gewoon verwerken. Ja, dat was echt moeilijk. Want ze stonden gewoon te gillen tegen elkaar, een uur voordat zij stierf. Ik vond dat vreselijk. Terwijl, als die meneer zich daar ook maar een beetje bij had kunnen neerleggen, hadden ze dat met elkaar kunnen regelen en nu niet. Maar ja, daar kun je toch niets aan veranderen. Er is genoeg met hem gepraat."

Verpleegkundige: "Kijk, ze zullen het dus toch samen met elkaar moeten doen. Ze moeten samen verder of niet natuurlijk, maar dan ook. Wij kunnen natuurlijk wel van alles doen en willen voor die patiënt, maar de familie is ook belangrijk en als ze er samen niet uitkomen is dat heel vervelend. Wat je graag wil voor die mensen is dat ze elkaar steunen, dat ze het samen kunnen rooien."

Verpleegkundigen signaleren bij patiënt en familie regelmatig behoefte aan ondersteuning van hun relatie, om de situatie waarin ze zich met elkaar bevinden hanteerbaar te maken. Het open houden en bevorderen van de communicatie tussen patiënt en familie is een manier waarop verpleegkundigen trachten een positieve bijdrage te leveren aan het contact tussen hen. Voor andere patiënten en hun naasten proberen verpleegkundigen de onderlinge relatie te verbeteren door begrip voor elkaar te creëren. Bijvoorbeeld in een situatie dat er ruzie was omdat de patiënt naar huis wilde, maar de familie dat niet wilde. Door elkaars standpunten te verduidelijken proberen verpleegkundigen wederzijds begrip te creëren.

Mevrouw $x$ is boos op haar man. Ze wil naar huis om thuis te sterven. Haar man wil dat niet. Lieve legt haar uit dat haar man misschien wel bang is dat hij niet goed genoeg voor haar kan zorgen. Bovendien heeft hij al eens meegemaakt hoe het is om voor iemand te zorgen die gaat sterven. Hij heeft zijn eerste vrouw thuis verzorgd. Mevrouw $\mathrm{x}$ zegt dat het nu toch allemaal anders zal gaan. Lieve belooft dat ze nog eens met meneer $x$ zal praten. Hem nog eens zal vertellen welke mogelijkheden er zijn voor thuiszorg. Maar mis- 
schien is dat wel niet de angst van mencer $x$ en wil hij gewoon niet nog eens meemaken hoe iemand thuis sterft.

In deze paragraaf zijn zorgbehoeften geanalyseerd die in het denken en har1delen van verpleegkundigen zijn geïdentificeerd en die te maken hebben met een confrontatie met een levensbedreigende ziekte. Verpleegkundigen proberen ervoor te zorgen dat voor patiënten die zich in deze omstandigheden bevinden de situatie te verdragen is, door aandacht te hebben voor emotionele pijn en lijden van patiënten. Bovendien hebben verpleegkundigen aandacht voor de relatie tussen patiënten en hun naasten vanuit de opvatting dat patiënten er behoefte aan hebben dat deze relatie ondersteunend voor hen is en zeker niet belastend.

\section{CONCLUSIE}

In dit boek worden morele ervaringen van verpleegkundigen met dagelijkse zorgverlening centraal gesteld, door aandacht te besteden aan de volgende vragen: wat verstaan verpleegkundigen onder goede zorg? hoe proberen ze deze te geven? tegen welke problemen lopen ze daarbij aan? Voor het empirische onderzoek zijn deze vragen - in hoofdstuk 3 - van uit zorgethisch perspectief verder geconcretiseerd. Dat heeft geleid tot de volgende vraagstellingen:

Aan welke zorgbehoeften die samenhangen met het in stand houden of herstellen van de wereld van patiënten proberen verpleegkundigen tegemoet te komen, zodat zij er zo goed mogelijk in kunnen leven?

Hoe proberen verpleegkundigen tegemoet te komen aan zorgbehoeften die samenhangen met het in stand houden of herstellen van de wereld van patienten, zodat zij er zo goed mogelijk in kunnen leven?

In dit hoofdstuk wordt de eerste vraagstelling beantwoord door te beschrijven, aan welke zorgbehoeften verpleegkundigen aandacht besteden. Op basis van de bevindingen die ik tijdens de intensieve periode van participerende observatie heb verzameld én op basis van de analyses daarvan die in dit hoofdstuk zijn beschreven, kan het streven van verpleegkundigen van afdeling ro om goede zorg te geven, benoemd worden als 'een streven om de situatie voor patiënten zo draaglijk mogelijk maken'. Voor verpleegkundigen van afdeling ro heeft de vraag hoe het leven van patiënten in stand gehouden kan worden of hersteld kan worden, zodat ze er zo goed mogelijk in kunnen leven, vooral te maken met ervoor zorgen dat het bestaan voor hen acceptabel is, aanvaardbaar is, niet te belastend is, prettig is, hanteerbaar is, en dergelijke. Waar het 
verpleegkundigen van afdeling Io vooral om gaat is, patiënten door het behandeld worden en opgenomen zijn voor een levensbedreigende ziekte heen te loodsen, op een manier die zo draaglijk mogelijk voor hen is.

De zorgbehoeften die verpleegkundigen signaleren om het bestaan voor patiëriten zo draaglijk mogelijk te maken, zijn in dit hoofdstuk geordend in drie categorieën. Het gaat om zorgbehoeften die samenhangen met intensieve en ingrijpende behandelingen aan het lichaam, om zorgbehoeften die te maken hebben met het opgenomen zijn in een ziekenhuis en om zorgbehoeften die samenhangen met de confrontatie met een levensbedreigende ziekte.

Doordat verpleegkundigen proberen het bestaan voor patiënten zo draaglijk mogelijk te maken, komen ze verschillende morele kwesties tegen, zoals: Hoe om te gaan met fysieke pijn en lijden van patiënten? Hoe kan een arts ertoe bewogen worden een pijnlijke handeling niet uit te voeren? Hoe kan een interventie aan het lichaam uitgevoerd worden op een manier dat een patiënt zo min mogelijk pijn lijdt? Hoe kan de patiënt geholpen worden zeggenschap te houden over zijn eigen lichaam? Wat te doen voor patiënten die het ondraaglijk vinden, om geïsoleerd verpleegd te worden? Wat te doen voor patiënten die angstig en onzeker zijn? Hoe kunnen familieverhoudingen verbeterd worden? Met dergelijke morele kwesties worden verpleegkundigen van afdeling ro geconfronteerd, wanneer ze proberen het bestaan voor patiënten zo draaglijk mogelijk te maken.

In dit hoofdstuk zijn morele ervaringen van verpleegkundigen ook inzichtelijk gemaakt door te bestuderen hoe verpleegkundigen proberen aan behoeften van patiënten tegemoet te komen. Daardoor is zichtbaar geworden dat verpleegkundigen veel verschillende activiteiten verrichten, om ervoor te zorgen dat het bestaan voor patiënten zo draaglijk mogelijk is. Als het gaat om zorgbehoeften die samenhangen met intensieve behandelingen die patiënten ondergaan, bieden verpleegkundigen bijvoorbeeld comfort of organiseren pijnbestrijding of gaan flexibel om met opdrachten van artsen. Wanneer het gaat om zorgbehoeften die samenhangen met het opgenomen zijn op een afdeling, trachten verpleegkundigen de omgeving voor hen meer vertrouwd te maken. Ze besteden aandacht aan de inrichting van de kamer, denken met patiënten mee hoe ze hun dag kunnen invullen of ze proberen de communicatie tussen patiënt en familie te bevorderen. In het kader van de categorie zorgbehoeften die samenhangen met de levensbedreigende ziekte, stimuleren verpleegkundigen bijvoorbeeld patiënten om hun verhaal te vertellen of geven feedback wanneer patiënten emotioneel lijden. Verpleegkundigen verrichten allerlei verzorgende activiteiten die erop gericht zijn het bestaan voor patiënten zo draaglijk mogelijk te maken.

Deze verzorgende activiteiten die verpleegkundigen verrichten hebben een moreel karakter, omdat ze erop gericht zijn het bestaan voor patiënten zo 
draaglijk mogelijk te maken. Dat is bijvoorbeeld het geval wanneer verpleegkundigen betrokken raken bij patiënten om hen emotioneel te steunen of wanneer ze zich opstellen als een compagnon. Deze activiteiten zijn er vooral op gericht, ervoor te zorgen dat de situatie voor patiënten te verdragen is. Vaak is een activiteit niet exclusief moreel, maar wordt met een verzorgende handeling meerdere doelen gediend. Verpleegkundigen verrichten tal van activiteiten die op het eerste gezicht louter praktisch of technisch van aard zijn. Verpleegkundigen informeren patiënten over ziekte en behandeling of over het reilen en zeilen van afdeling en instelling. Verpleegkundigen dienen patiënten medicatie toe of assisteren artsen bij een beenmergpunctie. Verpleegkundigen zorgen voor de lichamelijk conditie van patiënten. Dit lijken vooral praktische en technische activiteiten. Ze blijken echter een morele lading te hebben, omdat ze er tevens op gericht zijn het leven voor patiënten zo draaglijk mogelijk te maken. Wanneer verpleegkundigen patiënten een injectie toedienen, vragen ze zich tegelijkertijd af hoe een patiënt dat ervaart. Wanneer verpleegkundigen de wond van een patiënt verzorgen, hebben ze tegelijkertijd aandacht voor de betekenis die deze wond voor een patiënt heeft en welke pijn en ongemak daaruit voortvloeit. Wanneer verpleegkundigen patiënten uit bed tillen om decubitus te voorkomen, houden ze er rekening mee dat bewegen voor patiënten een onmogelijke opgave kan zijn. In het verrichten van allerlei dagelijkse activiteiten zit het morele opgesloten. Wanneer het morele van deze verzorgende activiteiten niet zichtbaar wordt gemaakt en niet wordt benoemd, verdwijnt daarmee een essentieel element van de zorg uit zicht, evenals een belangrijke motivatie van verpleegkundigen om te zorgen.

Hoe het bestaan voor patiënten draaglijk kan worden is geen vanzelfsprekende zaak. In dit hoofdstuk is aangegeven dat patiënten verschillende zorgbehoeften kunnen hebben, afhankelijk van de persoon die ze zijn en afhankelijk van de fysieke, psychische en sociale situatie waarin ze zich bevinden. Bovendien zijn zorgbehoeften veranderlijk. Niet alleen omdat het ziekteproces zich veelal kenmerkt door een grillig verloop, maar ook omdat patiënten het behandeld worden en opgenomen zijn voor een levensbedreigende ziekte steeds weer anders kunnen ervaren. Tegemoet komen aan zorgbehoeften van patiënten is een complex proces, omdat verpleegkundigen zich in ieder patiëntencontact moeten afvragen welke patiënt ze voor zich hebben. Waar heeft deze patiënt op dit moment behoefte aan, om het leven draaglijker te maken? Het complexe karakter van het hanteren van zorgbehoeften wordt nog versterkt, doordat niet altijd zonder meer duidelijk is waar een patiënt behoefte aan heeft. Bovendien kunnen verpleegkundigen onderling of verpleegkundigen en andere zorgverleners, een andere interpretatie geven aan zorgbehoeften van patiënten. 
In het volgende hoofdstuk wordt besproken dat het geen vanzelfsprekende zaak is om het bestaan voor een patiënt zo draaglijk mogelijk te maken. Het verrichten van moreel geladen activiteiten gericht op het tegemoet komen aan zorgbehoeften van patiënten, is daardoor inherent verbonden met onzekerheid. Dat wil niet zeggen dat verpleegkundigen voortdurend in een impasse zijn, maar dat het antwoord op de vraag 'hoe goed te doen' bijna nooit vastligt, maar altijd een zoekproces blijft. In het volgende hoofdstuk wordt daarop ingegaan. Bovendien komt in dat hoofdstuk aan de orde hoe verpleegkundigen dergelijke onzekerheid hanteren. 


\section{WERKEN MET ONZEKERHEID}

Dit boek heeft tot doel morele ervaringen van verpleegkundigen zichtbadr te maken. In dit hoofdstuk wordt daarom ingegaan op de volgende vraag:

In welke situaties komen verpleegkundigen moeilijkheden, problemen en belemmeringen tegen, juist omdat ze erop gericht zijn patiënten te ondersteunen bij het in stand houden of herstellen van hun wereld zodat zij er zo goed mogelijk in kunnen leven?

In het vorige hoofdstuk zijn morele ervaringen van verpleegkundigen van afdeling Io belicht door te bespreken aan welke zorgbehoeften van patiënten ze tegemoet willen komen en hoe ze dat proberen te doen. Daarbij is zichtbaar geworden dat verpleegkundigen emaar streven de situatie voor patiënten zo draaglijk mogelijk te maken. Verpleegkundigen proberen ervoor te zorgen dat patiënten zo goed mogelijk door het behandeld worden en opgenomen zijn voor een levensbedreigende ziekte heenkomen. In dit hoofdstuk worden morele ervaringen van verpleegkundigen onderzocht aan de hand van de vraag welke moeilijkheden, problemen en belemmeringen ze ervaren, wanneer ze proberen de situatie voor patiënten zo draaglijk mogelijk te maken. Daarbij is zichtbaar geworden dat verpleegkundigen onzekerheid ervaren bij het tegemoet komen aan zorgbehoeften van patiënten. Het is niet zo dat ze voortdurend in impasse verkeren, omdat ze niet weten wat ze moeten doen. Verpleegkundigen ervaren onzekerheid, omdat er niet één antwoord te geven is op de vraag wat patiënten nodig hebben om hun situatie als draaglijk te ervaren. Door deze onzekerheid te exploreren, worden morele ervaringen van verpleegkundigen van afdeling ro in dit hoofdstuk verder geanalyseerd.

In paragraaf I van dit hoofdstuk wordt besproken dat verpleegkundigen werken in onzekerheid. Wat maakt zorgen tot een onzekere aangelegenheid? Bovendien wordt belicht waarom deze onzekerheid moreel van aard is. In paragraaf 2 komt aan de orde hoe verpleegkundigen onzekerheid zo veel mogelijk proberen te voorkomen. In paragraaf 3 tot slot wordt getoond dat verpleegkundigen op momenten van onzekerheid ervoor proberen te zorgen dat ze niet in een impasse raken, maar dat ze erop gericht blijven dat de zorg doorgaat. 


\section{WERKEN IN ONZEKERHEID}

In het vorige hoofdstuk is beschreven welke activiteiten verpleegkundigen verrichten om het leven voor patiënten zo draaglijk mogelijk te maken. In dat hoofdstuk is het signaleren en tegemoet komen aan zorgbehoeften niet geproblematiseerd. In deze paragraaf komt aan de orde dat het hanteren van zorgbehoeften van patiënten geen vanzelfsprekende zaak is. Verpleegkundigen ervaren onzekerheid gedurende de zorg die zij aan patiënten geven. Ze vragen zich regelmatig af hoe ze goed kunnen doen. In concreto valt het handelen samen met de vraag: hoe kan voor deze patiënt op dit moment het leven zo draaglijk mogelijk gemaakt worden? Het blijkt dat hierop in de praktijk lang niet altijd een duidelijk antwoord te geven is. In het denken en handelen van verpleegkundigen is zichtbaar dat daar verschillende redenen voor zijn. In deze paragraaf wordt de aard van deze onzekerheid geanalyseerd door deze redenen te identificeren en te exploreren.

\section{Interpreteren van zorgbehoeften}

In deze paragraaf wordt besproken dat zorgbehoeften niet kant en klaar voor het oprapen liggen. In het denken en handelen van verpleegkundigen is zichtbaar dat zowel het signaleren van als het tegemoet komen aan zorgbehneften van patiënten vraagt om interpretatie.

\section{Signaleren}

Het is niet altijd zonder meer duidelijk waar een patiënt behoefte aan heeft. Bijvoorbeeld in een situatie waarin een patiënt aan een verpleegkundige vraagt waarom hij zo veel blauwe plekjes op zijn been heeft.

Wanneer ik met Petra bij meneer $x$ binnen loopt vraagt hij aan haar wat die

blauwe plekjes op zijn been betekenen. Petra legt uit wat ze betekenen.

Deze verpleegkundige vat de vraag van de patiënt op als een vraag om informatie. Hij wil weten wat er aan de hand is. Zoals in het vorige hoofdstuk is besproken zijn er verschillende redenen waarom patiënten behoefte hebben aan informatie over ziekte en behandeling. Bijvoorbeeld om zeggenschap te behouden of te verkrijgen over hun eigen lichaam. Vragen van patiënten over ziekte en behandeling worden door verpleegkundigen echter niet altijd geïnterpreteerd als een vraag om informatie. Soms worden deze gezien als een teken van angst of ongerustheid.

Mevrouw x vraagt aan de verpleegkundigen waarom haar huid zo'n pijn doet.

Dirk beantwoordt deze vraag met een tegenvraag: 'maakt u zich zorgen?'. Hoewel deze patiënt ook informatie vraagt over het effect van de behandeling op haar eigen lichaam, reageert deze verpleegkundige niet met het geven van 
informatie. Hij denkt dat deze mevrouw niet zo zeer behoefte heeft aan informatie, maar dat dit haar manier is om aan te geven dat ze zich zorgen maakt.

In het denken en handelen van verpleegkundigen zijn verschillende redenen te identificeren, waarom zorgbehoeften om interpretatie vragen. Soms weten patiënten bijvoorbeeld zelf niet waar ze behoefte aan hebben om het leven draaglijker te maken.

Tijdens de verzorging praat Elice met mevrouw $\mathrm{x}$. Deze geeft aan dat ze zich verschrikkelijk voelt. "Och kind, ik weet het toch niet. Ik heb me nog nooit zo ellendig gevoeld. Ik weet niet wat het is. Of ja, alles natuurlijk." Elice probeert te achterhalen of ze pijn heeft of dat ze verdrietig is.

Patiënten ondervinden op veel terreinen problemen. Deze kunnen de draaglijkheid van hun situatie ernstig aantasten. Wanneer patiënten verschillende zorgbehoeften tegelijkertijd hebben, weten ze soms zelf niet eens waar ze behoefte aan hebben. Verpleegkundigen moeten dan zien te achterhalen wat een patiënt nodig heeft. Zorgbehoeften vragen niet alleen om interpretatie omdat patiënten zelf soms niet weten welke zorg ze nodig hebben, maar ook omdat patiënten wel eens iets anders zeggen dan waar ze behoefte aan hebben.

Verpleegkundige: "Ik dacht dat hij behoefte had aan meer contact met zijn ouders, maar als ik daar iets van zei dan was het zo van 'flikker op'. Hij kon heel grof zijn. We hebben ook als team steeds geprobeerd te achterhalen wat hij van dat contact vond. Ook via de ouders. Maar hij wilde er niet aan. Zij ook niet. We hebben er nog een psycholoog bijgehaald, maar ze wilden niet. Ze hadden zoiets van 'zo gaan wij gewoon met elkaar om'. Dus toen hebben we het maar gelaten zo. Maar ik heb echt tot het laatste in dubio gezeten. Tot hij is overleden, van 'wat moet ik ermee?' En ik sloot me maar aan bij hetgeen we allemaal deden. Dat we als team ons er niet mee bemoeiden. En nu denk ik achteraf toch, op het eind is hij heel erg bang geweest, dat hij zich misschien toch zo afwijzend heeft gedragen, zo puberaal, dat dat een beschermmantel was. Zijn eigen gevoelens beschermen. Ik weet het niet."

Verpleegkundigen moeten zich in dergelijke situaties afvragen of een patiënt echt geen behoefte heeft aan ander contact met familie of dat een patiënt die stap niet durft te zetten. Wil een patiënt echt niet praten of durft hij niet, om welke reden dan ook?

\section{Beantwoorden}

In het voorafgaande is aan de orde gekomen dat het signaleren van zorgbehoeften vraagt om interpretatie. Dat is ook het geval voor het beantwoorden ervan. Wanneer een zorgbehoefte eenmaal is geinterpreteerd, is niet vanzelfsprekend wat de goede manier van reageren is. 
Verpleegkundige: "Soms beginnen mensen opeens te huilen als je binnenkomt. Dan weet je soms gewoon dat iemand bang is, maar dan denk ik toch wel 'oei hoe ga ik dat nu aanpakken?'."

Hoe kan een patiënt die bang is voor pijn en het lijden dat samengaat met behandeling, worden geholpen? De patiënt troosten door een arm om hem heen te slaan of er alleen even bij blijven zitten? De patiënt informatie geven over de behandeling en de pijn die daarmee gepaard gaat? De patiënt hoop geven door de positieve afloop te benadrukken? Wanneer verpleegkundigen zien dat een patiënt bang is en ze weten waarom, is nog niet vanzelfsprekend wat het goede antwoord is op een dergelijke vraag. Niet alleen het signaleren van zorgvragen vraagt dus om interpretatie. Hetzelfde geldt voor het zoeken naar een passend antwoord op een dergelijke vraag. Vaak gaat het interpreteren van een behoefte en het geven van een antwoord hierop samen. Achterhalen waar een patiënt behoefte aan heeft door een gesprek op gang te brengen is vaak al een antwoord op een behoefte. In het gesprek zelf krijgen vraag en antwoord hun vorm.

\section{Modelleren van zorgbehoeften}

Zorgbehoeften zien en er op reageren is geen eenzijdig proces van patiënt richting verpleegkundige. Verpleegkundigen hebben daar invloed op. Soms kunnen of willen ze zorgbehoeften niet oppakken. Soms sturen ze patiënten in een bepaalde richting door hun manier van vragen en reageren.

\section{Onderkennen}

Soms pakken verpleegkundigen signalen van patiënten niet op, omdat ze zich onzeker voelen of bang zijn een gesprek aan te gaan.

Verpleegkundige: "Als leerling is dat gevoel heel beangstigend. De relaties die ik op dat moment met patiënten had waten veel oppervlakkiger. Als patiènten wat emotie begonnen tê vertonen, dan kapte ik dat sneller af. Ik denk omdat ik bang was voor de emoties van een patiënt."

Soms negeren verpleegkundigen signalen bewust. Soms zien ze signalen niet. Dat is vooral het geval bij verpleegkundigen die nog weinig ervaring hebben in de zorg.

Verpleegkundige: "En vaak zag ik de tekens ook niet, terwijl ik daar nu wel sneller op inspring en ook niet bang ben als een patiënt in huilen uitbarst of wat dan ook."

Verpleegkundige: "Ik denk dat ik dat nu veel beter oppik dan in het begin. Als een patiënt in het begin iets tegen me zij met de bedoeling dat ik daarop verder in zou gaan, als hij echt met je wilde praten over iets, dan zag ik dat 
niet. Als je pas gediplomeerd bent of nog leerling, dan heb je die ervaring nog niet. Door ervaring denk ik leer je heel veel inzien."

Verpleegkundigen hebben ervaring nodig om zorgbehoeften te kurnen en durven zien. Maar zelfs als verpleegkundigen zeer ervaren zijn blijft onzekerheid bestaan over de vraag of zorgbehoeften van patiënten wel altijd gesignaleerd worden.

Verpleegkundige: “Nu hoop ik maar dat ik zie wanneer een patiënt verdrietig is of wil praten. Vroeger, dat weet ik van mezelf, dan zag ik dat soms gewoon niet, ik pikte dat niet op. Nu ben ik daar veel alerter op. Maar ja, je weet toch niet of er niet af en toe iets doorheen glipt. Dat zal heus wel gebeuren, maar dat probeer ik zo veel mogelijk te voorkomen. Maar ja, zeker weten doe je dat toch niet."

Zorgen voor patiënten is inherent verbonden met onzekerheid omdat verpleegkundigen zich afvragen of ze zorgbehoeften van patiënten adequaat onderkennen.

\section{Beïnvloeden}

Verpleegkundigen ervaren niet alleen onzekerheid omdat ze zich afvragen of ze zorgbehoeften wel oppikken, maar ook omdat ze zich realiseren dat door hun manier van vragen en reageren patiënten soms in een bepaalde richting worden gestuurd. Soms vragen verpleegkundigen zich af of ze door hun manier van reageren patiënten wel in de goede richting hebben gestuurd.

Verpleegkundige: "Ik moet zeggen dat ik helemaal niet negatief sta tegenover euthanasie. Ook niet omdat ik geen religieuze achtergrond heb. Ik denk dat dat hierin ook heeft meegespeeld. Dus dat ik me heel goed kan voorstellen dat iemand daarom vraagt. Dan ben je toch meer gedreven de wens van zo'n mevrouw in te willigen. Toevallig heeft zij naar mij toe haar euthanasievraag geuit. Ik heb dat dan een beetje geprobeerd op gang te brengen. Nou ja, toevallig, ik denk dat zij haar vraag naar mij toe heeft geuit, omdat ik daar niet helemaal objectief met haar over sprak. Dat als zij een beetje al iets liet merken, dat ik misschien toch wat subjectiever heb geantwoord. Dat zij dan toch proefde dat ik daar niet negatief tegenover sta. Iemand anders die had gezegd 'nee joh, dat gebeurt toch niet en je maakt geen kans'. Dan had zij dat misschien denk ik niet zo geuit. Zij begon er over in het kader van een gesprek dat we hadden. Dat zij het eigenlijk alleen maar bergaf zag gaan. Dat zij zich steeds slechter begon te voelen en ook steeds zwakker werd. Niet meer kon eten en bijna niet meer uit bed kon komen en dat wij haar daar toch steeds in probeerden te motiveren. Om meer te eten. Toch uit bed te komen. Om toch dingen te ondernemen. Om die blindheid te accepteren. Ze was ook nog blind geworden. Dat speelde er ook nog doorheen. In zo'n gesprek heeft zij dan duidelijk gemaakt 'ja, eigenlijk wil ik gewoon niet 
meer'. Ja en toen is dat aan het rollen gekomen. Ik denk dat ik een gesprekspartner was voor haar op dat moment. En nu denk ik dat ik te subjectief ben geweest. Ik denk dat je normaal een objectieve gesprekspartner moet zijn. Ja, ik bedoel dus meer, in dit geval bij die mevrouw, ja, hoe moet ik dat zeg. gen. Als zij die vraag aan iemand anders had gesteld, die daar heel negatief tegenover had gestaan, dan was alles misschien wel anders gelopen. Ik heb nu dingen op gang gebracht. De arts van dat moment erbij gehaald. Die stond toevallig ook niet negatief ten opzichte van euthanasie. Ik denk dat als een verpleegkundige aan het werk was geweest die daar heel negatief tegenover had gestaan, dat die de zaak anders had aangepakt en dat dan verder geen actie was ondernomen. Dat denk ik, maar dat weet ik niet zeker. Of dat beter was geweest weet ik niet, weet ik niet."

Deze verpleegkundige vraagt zich af of ze de euthanasievraag bij deze mevrouw niet heeft gestimuleerd door deze expliciet te benoemen en de vraag bij artsen aan te kaarten. Tegelijkertijd realiseert ze zich dat deze patiënt juist bij haar deze vraag heeft geuit, omdat zij daarvoor de ruimte heeft gecreëerd. Toch vraagt ze zich af of ze daar wel goed aan heeft gedaan. Zou het hele proces voor deze mevrouw niet heel anders gelopen zijn wanneer een andere verpleegkundige op dat moment tegenover deze mevrouw gezeten had, die haar uiting niet als een vraag om euthanasie had geinterpreteerd? Verpleegkundigen realiseren zich dat ze zelf invloed hebben op de manier waarop patiënten hun behoeften vorm geven. Dat leidt ertoe dat verpleegkundigen zich soms onzeker voelen over de vraag of ze wel goed doen.

Verpleegkundige: "Mensen vragen wel eens 'wat zou jij doen?'. Dan ben ik altijd wel heel voorzichtig, want ik ben niet iemand van de straat, zeg maar. Dat geldt zeker voor artsen, wat die zeggen daar doen mensen wat mee. Maar wij ook. Je moet je goed realiseren dat mensen naar je luisteren en iets doen met de dingen die je zegt. Niet altijd natuurlijk. Maar toch. Dus als mensen vragen 'wat zou jij doen' dan denk ik daar wel over na, maar dan zeg ik ook altijd dat ik toch niet weet hoe het is als het aan je lijf aan het vreten is. Je weet toch nooit hoe dat is."

Het proces van signaleren en tegemoet komen aan zorgbehoeften van patiënten is verbonden met onzekerheid. Dat is het geval omdat zorgbehoeften opgepikt moeten worden. Bovendien realiseren verpleegkundigen zich dat ze zelf invloed uitoefenen op dat proces. Ze vragen zich af of ze dat wel goed doen, vooral omdat het gaat om een groep mensen die bijzonder kwetsbaar is omdat ze met de dood geconfronteerd worden. 


\section{Verschillende inzichten}

In deze paragraaf wordt de aard van onzekerheid besproken die verbonden is met zorgverlening. Waarom vragen verpleegkundigen zich soms af of de zorg die ze geven de situatie voor patiënten wel draaglijker maakt? Dat is het geval omdat er niet één antwoord is op deze vraag.

In het vorige hoofdstuk is beschreven welke activiteiten verpleegkundigen verrichten om het leven voor patiënten zo draaglijk mogelijk te maken. In dat hoofdstuk is gezocht naar algemene opvattingen van goede zorg. Dat wil echter niet zeggen dat sommige verpleegkundigen daar niet van kunnen afwijken of dat er op een bepaald moment geen verschillende inzichten kunnen zijn tussen verpleegkundigen over wat goed is om te doen. Soms is dat namelijk wel het geval, zoals in de nu volgende situatie.

Verpleegkundige: "We hadden het idee dat het niet goed was voor de patiënt. Ze is 23 jaar. Die moeder nam alles van haar over. Dus zij kwam niet meer uit bed. Ze werd compleet op bed gewassen. Deed haar armen niet meer omhoog om haar kleren aan te trekken. Dus echt de zorg totaal overnemen eigenlijk."

Een andere verpleegkundige over dezelfde situatie: "Je probeerde haar gerust te stellen, was met haar bezig en dan kwam die moeder er weer tussen. Je kreeg helemaal niet de kans met haar bezig te zijn. Dan heb je het gevoel dat je heel erg machteloos staat. Terwijl je het gevoel had dat ze de moed aan het verliezen was en het erg moeilijk had met de situatie, maar daar kwam je eigenlijk niet aan toe. Je kon geen band krijgen met haar en achterhalen wat er werkelijk in haar omging. Iedere keer als je haar iets vroeg dan gaf haar moeder antwoord."

Sommige verpleegkundigen vonden dat de relatie die deze jonge vrouw met haar moeder had de draaglijkheid van de situatie voor de patiënt zelf in de weg stond. Verpleegkundigen dachten dat ze de moed aan het verliezen was en het heel moeilijk had, maar dat zij niets voor haar konden doen omdat haar moeder dit belemmerde. Andere verpleegkundigen vonden echter dat dit de manier was waarop deze mensen met elkaar omgingen en dat verpleegkundigen zich daar niet mee moesten bemoeien.

Verpleegkundige: "Ik denk dat de belangrijkste vraag van patiënten is 'laat me doen hoe ik ben'. Hiermee sta ik soms niet op één lijn met anderen. Met dat jonge meisje bijvoorbeeld. Mensen van de afdeling die dan een bepaalde houding willen afdwingen. Bijvoorbeeld, de moeder mag hier niet blijven 's nachts. Terwijl ze dat heel prettig vindt. Dus, ik had nachtdienst en ik dacht 'ik beslis daarover of die mevrouw mag blijven of niet'. Die mevrouw belde vier of vijf keer per nacht om te vragen hoe het met haar dochter was. Ik bedoel, als het niet te ver indruist tegen het dagplan, want ik wil ook niet vol- 
ledig oppositie voeren, maar ik vond ook dat die vrouw meer rust kreeg in dan buiten het ziekenhuis. Niet voor de patiënt, maar voor haar. En toen heb ik mijn been stijf gehouden. En die patiënte zelf die wilde ook dat haar moeder bleef. Iedereen bemoeide zich met die mensen. I heb me daar toen ook mee bemoeid. Maar om hun een beetje vrijheid te geven, om die familie te verdedigen, hun gedrag. Ik wil niet zeggen dat je je nooit met zo'n relatie moet bemoeien, maar vaak lossen ze het beter zelf op."

Op zichzelf hoeven verschillende inzichten niet tot onzekerheid bij verpleegkundigen te leiden. Wanneer ieder voor zich weet hoe het leven voor een patiënt draaglijker gemaakt kan worden, dan kan de betreffende verpleegkundige daarnaar handelen. Verpleegkundigen gaan er echter vanuit dat ze weliswaar ieder op hun eigen manier mogen zorgen, maar dat te grote verschillen daarin de situatie voor een patiënt minder draaglijk maken.

Verpleegkundige: "leder heeft zo zijn eigen manier van doen en manieren om voor patiënten te zorgen. Dat is ook goed. Zo kunnen we elkaar aanvulling. Dat is de kracht van een team."

Verpleegkundige: "We moeten toch één lijn volgen, dat kan niet anders. Het kan niet zo zijn dat de éen zegt van 'blijf maar slapen' tegen die moeder, terwijl iemand anders zegt dat dat niet kan. Dat kan natuurlijk niet. Dan weten die mensen niet waar ze aan toe zijn. Dat is ook niet goed." Verschillende inzichten leiden niet zonder meer tot onzekerheid. Dat is wel het geval wanneer deze verschillen de draaglijkheid van de situatie voor patiënten ondermijnen, waardoor niemand meer weet wat er gedaan moet worden.

Verpleegkundige: "Ik vind dat we nu toch iets moeten afspreken. Ik vind het heel vervelend dat iedereen anders met haar blijft omgaan. Dat is zo onduidelijk. Mag die moeder nu blijven slapen of niet. Ik weet het niet meer. Voor de patiënt is dat niet goed, maar voor ons ook niet, voor mij. Dat kan zo niet langer. Als ik de kamer op ga weet ik nu al niet wat ik moet doen. Dan vraagt die moeder wat en dan denk ik, ja, nee."

Vooral verpleegkundigen die minder ervaring hebben kumnen last krijgen van verschillende inzichten tussen verpleegkundigen. Ze worden zelf onzeker, wanneer onduidelijkheid blijft bestaan over de vraag hoe het leven voor een patiënt zo draaglijk mogelijk gemaakt kan worden. Door haar moeder haar gang te laten gaan of juist niet? Steeds weer opnieuw is onduidelijk wat te doen. In ieder patiëntencontact wordt deze onzekerheid dan pregnant gevoeld. 


\section{Veranderlijke zorgbehoeften}

Naast bovengenoemde punten is zorg ook inherent onzeker omdat zorgbehoeften van patiënten aan verandering onderhevig zijn. Deze veranderlijkheid is op verschillende plekken te lokaliseren.

\section{Fysieke situatie}

In het vorige hoofdstuk is besproken dat verpleegkundigen aandacht hebben voor fysieke pijn en lijden van patiënten. Ze bieden patiënten fysieke troost en comfort of organiseren pijnmedicatie, wanneer ze merken dat patiënten daar behoefte aan hebben. In het denken en handelen van verpleegkundigen is zichtbaar dat ze voortdurend alert zijn op pijn en lijden van patiënten, omdat ze weten dat zich dit kan voordoen maar het nooit precies te voorspellen is wanneer.

Verpleegkundige: "Je weet nooit hoe het gaat. Patiënten zijn toch altijd weer anders. Tijdens de behandeling denk je soms 'en nu gaat het goed'. Dan kom je de volgende dag op het werk en dan blijkt iemand opeens snel bergafwaarts te gaan. Daar moet je altijd op bedacht zijn."

Van de één op de andere dag of uur kan het klinisch beeld van patiënten veranderen. Voelt iemand zich 's morgens nog redelijk goed, 's middags kan iemand misselijk en doodziek zijn. Vaak is het niet te voorspellen hoe het ziekteverloop zich ontwikkelt of hoe een patiënt op een behandeling reageert.

\section{Emoties van patiënten}

De manier waarop patiënten het ziek zijn, het behandeld worden en het opgenomen zijn ervaren is volgens verpleegkundigen bijzonder veranderlijk. lemand kan het ene moment vol goede moed zijn en het een paar uur laten allemaal niet meer zien zitten.

Om I2.00 uur delen verpleegkundigen de warme maaltijd uit. Vanmiddag loop ik met Elice mee. Met een dienblad in de hand lopen wij kamer 4 binnen. Als we binnenlopen bij meneer $x$ begint hij te huilen. Vanmorgen toen we hem zijn ontbijt gingen brengen was hij vol goede moed en kon hij niet snel genoeg beginnen met chemo. Maar nu is heeft hij het heel erg moeilijk gekregen en begint en begint te huilen."

Deze meneer was 's ochtends nog bijzonder optimistisch. De verpleegkundige had dan ook niet het idee dat deze meneer ondersteuning nodig had bij het omgaan met zijn ziekte of de behandeling. Drie uur later is de situatie geheel anders. Opeens ziet deze patiënt het allemaal niet meer zitten. De patiënt ervaart het behandeld worden op dat moment als een emstige belasting waar hij niet tegen opgewassen is. Hij heeft de zorg van verpleegkundigen nodig om de situatie weer draaglijker te maken Verpleegkundigen zijn er 
op voorbereid dat patiënten van alles kunnen meemaken en ervaren. Wanneer zich dat voordoet is vaak niet te voorspellen. Wanneer verpleegkundigen binnen lopen bij patiënten, bijvoorbeeld om te kijken of ze al op zijn en zich gewassen hebben of het eten te brengen, weten ze nooit in welke hoedanigheid zij hen aan zullen treffen.

\section{Sociale relaties}

In het denken en handelen van verpleegkundigen is zichtbaar dat ze ook geconfronteerd worden met veranderlijkheid van zorgbehoeften, omdat relaties die patiënten onderhouden met familie, vrienden en bekenden veranderlijk zijn.

Verpleegkundige: "Op een gegeven moment, dat heeft iedere patiënt denk ik op zijn tijd, omdat hij met zoveel dingen tegelijk zit, kan het gewoon escaleren. Ook bij naaste familieleden. Een tijd geleden is dat geweest. Een meneer, oncologie patiënt, die zijn echtgenote begon uit te schelden. En dan sta je op die kamer en dan begin hij te schelden. Dan denk je 'wat krijgen we dan nu?' Maar gewoon omdat hij zich niet goed voelt en allerlei vragen en angsten heeft. Wie is dan degene die dan dicht bij staat? Je eigen vrouw, daar kun je tegen schreeuwen. Dan denk ik 'had ik nu wat moeten zeggen op dat moment? Moeten ingrijpen?' Want och arme, die vrouw kreeg echt de volle laag. Zo van 'stomme trut en wat doe je nu achterlijk' en ik weet niet wat allemaal."

\section{Patient als persoon}

Verpleegkundigen houden er niet alleen rekening mee dat zorgbehoeften die samenhangen met de fysieke, emotionele en sociale situatie van patiënten kunnen veranderen, maar ook dat de patiënt als persoon veranderlijk is.

Verpleegkundige: "Wat je dan vroeger belangrijk vond, dat kan opeens anders worden. Je hebt mensen die bijvoorbeeld alleen maar met hun werk bezig waren en dan nu beseffen dat ze dat eigenlijk niet meer willen."

Wie patiënten als persoon zijn en wat ze belangrijk vinden in het leven, kan volgens verpleegkundigen veranderen als gevolg van het ziek zijn. Dat wat altijd vanzelfsprekend was, is dat niet meer langer. Patiënten kunnen andere waarden en doelen krijgen in het leven, waardoor behoeften aan zorg weer anders kunnen zijn.

\section{Morele aard van onzekerheid}

In het voorafgaande is besproken dat het signaleren en hanteren van zorgbehoeften inherent verbonden is met onzekerheid. Vooraf is niet altijd duidelijk welke weg bewandeld kan worden om de situatie voor een patiënt draaglijker 
te maken. Soms zelfs is achteraf nog niet te zeggen of - wanneer er andere keuzes waren gemaakt - de zorg beter had aangesloten bij vragen en problemen van patiënten.

Verpleegkundige: "Je vertelt haar dan niet dat die andere mevrouw dood is gegaan, omdat zij zelf zo met de dood bezig is. En achteraf gezien heeft ze het via een collegaatje dat opbelde gehoord. Zo van 'goh die mevrouw is ook: gestorven'. En toen bleek: dus, dat ze er helemaal van ondersteboven was. Hadden we het misschien wel moeten zeggen? We hadden een keuze gemaakt in samenspraak met haar man. En ik dacht 'hij weet het beste hoe zij reageert en hoe ze er nu tegenaan kijkt'. Maar ja, of je dat goed heb gedaan, dat weet je nooit. Achteraf weet je vaak niet of, als je het anders had gedaan of het dan misschien beter was geweest."

De onzekerheid die verpleegkundigen ervaren is moreel, omdat er iets waardevols op het spel staat, namelijk: de draaglijkheid van het bestaan. Op afdeling ro wordt dat door verpleegkundigen in het bijzonder gevoeld omdat patiënten misschien wel dood gaan.

Verpleegkundige: "We verkopen hier geen benzine. Als je het dan verkeerd doet is dat ook vervelend natuurlijk. Maar de mensen hier, die gaan misschien wel dood."

In de zorg die verpleegkundigen geven staat de draaglijkheid van het bestaan op het spel, in omstandigheden dat patiënten misschien wel dood gaan. In dergelijke situaties is het belangrijk om het goed te doen.

Verpleegkundige: “Dat was een jong meisje, die is overleden. Ik was er met haar echtgenoot bij. En het moment dat het echt heel slecht gaat, dan ben je met de begeleiding bezig van haar en haar man. Maar je bent ook met alle technische zaken bezig: omschakelen van infusen. Dat moet allemaal gebeuren. Oh, mijn god, ja, ik ben echt een hele lange tijd bij hen gebleven. En wat ik dan heel moeilijk vind, is dat ik me zo machteloos voelde. Dan denk ik 'op die momenten sta je er helemaal alleen voor'. Dat vind ik echt heel griezelig hoor. Ook voor jezelf. Allemaal vragen van haar: 'als ik maar geen pijn heb en wat komt er hierna?'. Hoeveel je ze ook probeert te helpen, op dat moment kun je alleen maar hopen dat je wat geruststellende woorden zegt. Je weet wol c'igelijk helemaal niet wat dat voor hen betekent wat je op die mominten zegt." Wanneer verpleegkundigen het gevoel hebben dat de draaglijkheid van het bestaan van patiënten ernstig op het spel staat, kan dat er toe leiden dat ze zich machteloos voelen.

Verpleegkundige: "Dan heb je het bijvoorbeeld over een isolatie, drie, vier, vijf weken. De patiënt krijgt de muren langzaam op zich af. Het wordt eng, die deur blijft dicht. Het zit tussen de oren. En dan blijven proberen er door heen te komen. En dan heimwee, probeer dat maar eens. Die mevrouw met heimwee, dat is echt triest. Moeilijk eten, wil niet meer. Ze zei 'ze hebben me 
gezegd vijf weken, ik wil naar huis en als jullie niets doen dan trek ik dat ding, de Hickmann eruit, ik ga'. Ik zeg altijd reken op vier tot zes weken, is het wat korter, dan is het meegenomen. Maar bij haar, proberen te helpen, te helpen. Huilen, huilen is wat ze deed. Het enige wat je kunt doen is op dat moment luisteren, laat maar brullen. Zo'n heimwee. Je kunt doen wat je wil. Haar proberen bezig te houden, te praten, er is niet doorheen te komen. Dan vraag je je af 'wat moet ik hiermee?'. Het enige was, laat maar huilen. Geef die schouder en laat maar gaan. Met iets anders is ze niet gebaat. Zelf sta je dan ook voor het blok. Je staat ook tegen de muur. Het moeilijke is, potverdorie, je kunt geen kant uit. Dat mens heeft heimwee. Wat moet ik doen? Ik kan niets doen?"

Soms weten verpleegkundigen niet hoe ze de situatie voor een patiënt draaglijker kunnen maken. Ze kunnen niet meer doen dan deze patiënt de ruimte geven zich te uiten. In sommige situaties wordt onzekerheid over de vraag wat goed is om te doen zo pregnant gevoeld dat verpleegkundigen als het ware zelf 'lijden' onder de situatie, omdat ze lijdzaam moeten toezien hoe een situatie door een patiënt als extreem ondraaglijk wordt ervaren en ze niet weten hoe ze goed kunnen doen.

In deze paragraaf is aan de orde gekomen dat verpleegkundigen zich soms afvragen hoe ze voor een patiënt de situatie draaglijker kunnen maken. Deze vraag wordt regelmatig gesteld omdat niet zonder meer duidelijk is waaraan een patiënt behoefte heeft. Zorgbehoeften liggen niet kant en klaar voor het oprapen. Daarom vraagt het signaleren er van als ook de reactie er op om interpretatie. Ook brengt zorg onzekerheid met zich mee, omdat verpleegkundigen tot verschillende inzichten kunnen komen over zorgbehoeften. Hierdoor kan onduidelijkheid ontstaan over de vraag hoe de situatie voor een patiënt draaglijker gemaakt kan worden. Tot slot is soms niet zonder meer duidelijk waar een patiënt behoefte aan heeft, omdat zijn situatie veranderlijk is op fysiek, emotioneel en sociaal vlak en wat betreft de patiënt als persoon. Haast in ieder patiëntencontact vragen verpleegkundigen zich af welke patiënt ze voor zich hebben en wat deze nodig heeft om de situatie zo draaglijk mogelijk te maken. Deze vraag is moreel, omdat de kwaliteit van leven van mensen in het geding is. Wanneer verpleegkundigen zien dat patiënten zich in een zeer ondraaglijke situatie bevinden, kunnen ze zich bijzonder machteloos voelen als ze lijdzaam moeten toezien zonder een adequate reactie te weten.

In het voorafgaande is beschreven dat verpleegkundigen werken in onzekerheid. In de volgende paragraaf komt aan de orden hoe verpleegkundigen werken aan onzekerheid. Door gebruik te maken van allerlei soorten kennis en vaardigheden, kunnen ze voorkomen dat ze in een impasse raken over de vraag hoe ze voor een patiënt de situatie zo draaglijk mogelijk kunnen maken. 


\section{WERKEN AAN ONZEKERHEID}

Hoewel regelmatig niet zonder meer duidelijk is waar een patiënt behoefte aan heeft, hoeven verpleegkundigen daardoor niet in een impasse te raken. Ze gebruiken abstracte kennis, individuele kennis en relationele vaardigheden om situaties te voorkomen waarin onduidelijkheid bestaat over de vraag hoe het goede te doen.

\section{Abstracte kennis}

In deze paragraaf komt aan de orde dat verpleegkundigen gebruik maken vin abstracte kennis om zorgbehoeften van specifieke patiënten te signaleren en erop te reageren.

\section{Theoretische- en ervaringskennis}

In het denken en handelen van verpleegkundigen is zichtbaar dat ze gebruik maken van kennis met een abstract karakter. Deze kennis is niet verbonden met individuele patiënten, maar met de patiëntencategorie in het algemeen. In het nu volgende wordt getoond dat deze kemnis afkomstig is van verschillende bronnen. Bovendien wordt aangegeven van welke onderwerpen verpleegkundigen abstracte kennis hebben.

Verpleegkundigen gebruiken kennis die afkomstig is uit de opleiding, bijscholingen, cursussen, congressen of artikelen uit tijdschriften.

Verpleegkundige: "Belangrijk is dat je toch op de hoogte bent van de kennis van de patiëntengroep waar je mee werkt. Dat je dus niet, billen wassen en haren wassen en bed opmaken, en dat het daar dan mee eindigt. Je moet toch een beetje weten wat voor behandelingsmethoden er zijn. Ja, de ziekte, het vervolg van de ziekte, de complicaties die ze kunnen krijgen. Ja, dat vind ik. toch heel belangrijk, dat je dat weet. Daarom ben ik ook blij dat ik toch de oncologie cursus heb gedaan. Dat was wel zwaar, maar daar heb ik toch veel geleerd."

Daarnaast vertellen ook artsen en ervaren verpleegkundigen dergelijke informatie over ziekte en behandeling. Met name tijdens overdrachten wordt dergelijke kennis door hen aan verpleegkundigen overgedragen. Eèn van de verpleegkundigen werkt bovendien niet alleen op afdeling Io, maar is ook werkzaam bij het Integraal Kankercentrum. Zij heeft expliciet de task theoretische kennis te verzamelen en op de afdeling te verspreiden. Daarnaast heeft abstracte kennis als bron de ervaring. Deze ervaringskennis is weliswaar in eerste instantie verzameld bij individuele patiënten, maar heeft zich in de loop der jaren gebundeld tot een type kennis dat los staat van individu- 
ele patiënten en verbonden is geraakt met de patiëntencategorie in het algemeen.

Verpleegkundige: "Dan merk je toch wel, dat je door de jaren heen veel leert, doordat je voor de patiënten die hier door de jaren heen gelegen hebben, hebt verzorgd. Dus zorgen voor deze categoriepatiënten, daar leer je natuurlijk veel van."

Door jarenlang voor een bepaalde patiëntengroep te zorgen verzamelen verpleegkundigen veel kennis. Door ervaring wordt kennis gebundeld. Verpleegkundigen bouwen zelf deze kennis op. Bovendien wordt deze tijdens overdrachten aan elkaar uitgewisseld en met elkaar gedeeld.

Verpleegkundigen verzamelen en gebruiken abstracte kennis om zorgbehoeften te interpreteren en beantwoorden. Bij het bestuderen van de zorg die verpleegkundigen van afdeling to aan patiënten geven is zichtbaar dat ze van verschillende onderwerpen abstracte kennis hebben. Verpleegkundigen hebben bijvoorbeeld kennis van de fysieke situatie van patiënten en effecten van behandeling en ziekte.

Verpleegkundige: "Ik heb veel kennis van deze patiëntencategorie, mag $i \mathrm{k}$ toch wel zeggen. Door de jaren heen heb ik veel geleerd. Maar ik moet ook zeggen dat als ik iets niet weten over ziektebeelden, behandeling, onderzoeken en dergelijke, dan zoek ik dat ook altijd op. Ik zorg wel dat ik te weten kom wat ik nodig heb."

Daarnaast weten verpleegkundigen uit de opleiding, door het lezen van literatuur en uit ervaringen hoe patiënten emotioneel kunnen reageren op hun situatie. Ze weten waar patiënten het moeilijk mee kunnen krijgen of waar ze last van kunnen hebben.

Verpleegkundige: "Door al de jaren heen heb je wel ervaren dat het mensen heel erg kan opluchten om te praten. Nu durf ik daar ook op aan te sturen. Vroeger durfde ik dat niet zo. Nu wel."

Bovendien weten verpleegkundigen dat sociale relaties waarin patiënten verbonden zijn, kunnen veranderen als gevolg van de opname.

Verpleegkundige: "Mensen onderling, met familie, ze hebben vaak veel steun aan elkaar. Dat is mooi om te zien."

Verplegkundige: "Wat je ook gewoon weet is dat familie het er moeilijk mee heeft. Daar moet je dus ook op letten. Hoe die reageren op de opname, en of je daar eventueel van steun kan zijn."

Zoals ook in het vorige hoofdstuk aan de orde is gekomen, zijn relaties die patiënten met hun belangrijke naasten hebben van belang in het kader van de zorgverlening. Deze relaties kunnen zowel ondersteunend als belemmerend werken, waar het gaat om de vraag of patiënten hun situatie als draaglijk ervaren. Verpleegkundigen weten ook hoe dergelijke relaties onder druk kunnen komen als gevolg van de situatie waarin ze zich met elkaar bevinden. 


\section{Abstracte kennis als zoeklicht}

Vaak is niet zonder meer duidelijk wat een individuele patiënt nodig heeft om de situatie draaglijker te maken. Om te weten hoe ze voor een specifieke patiënt goed kunnen doen, maken verpleegkundigen gebruik van abstracte kennis over de fysieke, emotionele en sociale situatie van de patiëntencategorie in het algemeen. Verpleegkundigen weten bijvoorbeeld op welke fysieke verschijnselen ze alert moeten zijn. Ze weten dat ze op blauwe plekjes moeten letten, op infecties van slijmvliezen, op schilferige huid, patiënten die klagen over jeuk, patiënten die misselijk zijn, etc.

Verpleegkundige: "Van verschillende soorten patiënten leer je de behandeling kennen en de complicaties die zich kunnen voordoen. Omdat je voor veel verschillende patiënten hebt gezorgd en hebt meegemaakt, weet je ook hoe het de behandeling verloopt. Je weet waar je op moet letten en je kunt beter observeren. Dingen ontgaan je niet gauw. Bijvoorbeeld aandachtspunten bij zorg voor de mond, die moet je dus in de gaten houden. Wanneer de mond wordt gesprayd moet je goed kijken. Nu hoef je maar even te kijken en meteen valt je alles op."

Verpleegkundigen weten ook hoe patiënten emotioneel gezien kunnen reageren op het behandeld worden en opgenomen zijn voor een levensbedreigende ziekte en zijn daar alert op.

Verpleegkundige: "Je weet dat mensen het moeilijk krijgen als ze de isolatie ingaan. Dat weet je gewoon. Ik heb nog nooit een patiënt meegemaakt. die daar geen last van had. Dus daar moet je ook weer rekening niee houden." Abstracte kennis fungeert als het ware als een zoeklicht dat de blik focust. Omdat verpleegkundigen weten hoe deze patiëntencategorie fysiek, emotioneel en sociaal gezien reageert op het behandeld worden en opgenomen zijn voor een levensbedreigende ziekte, weten ze waarop ze moeten letten in specifieke patiëntencontacten. Onzekerheid kan worden voorkomen door gebruik te maken van abstracte kennis.

\section{Individuele kennis}

Zoals in paragraaf $\mathrm{I}$ is besproken is niet altijd zonder meer duidelijk wat een patiënt nodig heeft om de situatie als draaglijker te ervaren. Om te voorkomen dat verpleegkundigen daardoor niet weten wat ze moeten doen, maken ze gebruik van verschillende soorten kennis. Naast abstracte kennis is dat individuele kennis. Verpleegkundigen verzamelen kennis over de individuele patiënt om met elkaar een beeld van hem of haar te creëren, zodat ze van daar uit zorgbehoeften kunnen interpreteren. 


\section{Fysieke, emotionele en sociale situatie}

Om begrip te krijgen voor de vragen en behoeften van patiënten, verdiepen verpleegkundigen zich in hun fysieke, emotionele en sociale situatie.

Verpleegkundige: "Waar het bij ons om gaat is de totaliteit van die patiënt.

Zowel fysiek, als ook psychisch als het sociale."

Verpleegkundige: "Want je moet eerst eens kijken: deze mevrouw: wat heb $u$ me te vertellen en hoe voelt $u$ zich? Welke klachten hebt $u$ en hoe is uw situatie?"

In het denken en handelen van verpleegkundigen is zichtbaar dat ze begrip willen krijgen voor een patiënt. Waar heeft deze patiënt last van of ervaart hij pijn? Is deze patiënt angstig, verdrietig of juist hoopvol? Hoe is het contact met partner en/of kinderen? Verpleegkundigen willen zicht krijgen op de situatie van een patiënt, omdat dit iets zegt over zijn of haar vragen en behoeften.

\section{Patient als persoon}

Daarnaast verdiepen verpleegkundigen zich in de patiënt als mens, als persoon.

Verpleegkundige: "Ik vind dat je een patiënt moet laten zoals ie is, met hetgeen wat hij bij zich heeft aan bagage van zichzelf. Door je hele leven krijg je bagage mee, en dat moet je respecteren vind ik. Het is een mens, we zijn niet met robatjes en niet met dieren bezig, dat vind ik heel belangrijk. Dat wil ik ook dat ze dat bij mij doen."

Verpleegkundigen gaan ervan uit dat patiënten als persoon hun eigen voorkeuren, routines en 'manieren van doen' hebben. Ze willen deze leren kennen, niet alleen om ze te respecteren maar ook omdat deze iets zeggen over de patiënt die ze voor zich hebben.

Verpleegkundige: “Gewoon, met elkaar praten, over thuis, werk, hobby's, buurt, noem maar op. Dan leer je iemand kennen."

Het is volgens verpleegkundigen belangrijk zich te verdiepen in de patiënt als persoon, omdat dit iets zegt over hoe patiënten hun situatie ervaren en welke behoeften aan zorg daaruit voortvloeien.

Verpleegkundige: "Een patiënt kan bijvoorbeeld pijn of ongemak ervaren. Er zijn mensen die met pijn en ongemak kunnen leven. Dat is hun manier van leven. En als jij je dat niet kunt voorstellen. Ja dan. Je moet kijken van wat vindt die patiënt, hoe is de ervaring voor hem of hoe beleeft hij dat. Dus vanuit de patiënt. Wat geeft hij aan en wat is voor hém in die situatie belastend, vervelend of problematisch. Dus niet vanuit jezelf."

Verpleegkundige: "Het kan wel eens gebeuren dat iemand vervelend op je overkomt, bijvoorbeeld dat hij heel vies ruikt of onverzorgd is. Dat vind ik zelf, dat weet ik van mezelf, dat vind ik brrr. Dan moet ik even nadenken en 
dat gaat niet altijd automatisch, dan moet ik even denken van 'nou daar zet ik me overheen', snap je. Het is een patiënt, dus daar moet ik me overheen zetten. Als het me interesseert om de leefwereld van die mens te snappen, hoe hij zich nu voelt, wat voor hem belangrijk is en dat ik dat ook kan begrijpen, dan moet ik daar overheen stappen."

Verpleegkundigen hebben er bovendien oog voor dat patiënten als persoon kunnen veranderen.

Verplergkundige: "Ik sta zo te kijken van meneer $\mathrm{x}$. Dat heb ik hern ook gezegd. Hij is zo veranderd. Toen hij hier pas kwam was hij overal bang voor en nu, hoe zal ik dat zeggen, hij is zo sterk geworden. Dat zegt hij zelf ook. De ziekte heeft me nog wat opgeleverd ook."

Om onzekerheid te voorkomen verdiepen verpleegkundigen zich in de individuele situatie en persoon van een patiënt. In het nu volgende laat ik zien dat dit een voortdurend proces is, met als doel een beeld te creëren van de persoon en van de situatie van een patiënt

\section{Totaalbeeld maken}

Verpleegkundigen verdiepen zich in de situatie en persoon van een patiënt om een totaalbeeld te creëren.

Verpleegkundige: "Het is eigenlijk een totaalplaatje, wat er met een patiënt is

en wat een patiënt laat zien op de afdeling."

Om een totaalbeeld samen te stellen verdiepen verpleegkundigen zich op verschillende manieren in de individuele situatie en persoon van een patiënt. Op de eerste plaats doen ze dat door goed naar patiënten te kijken. Ze observeren de huid, het wit in de ogen, hoe patiënten ademhalen, hoe ze bewegen, etc. Ze observeren patiënten ook om te achterhalen hoe deze zich voelen. Zijn patienten verdrietig, bang, angstig of onzeker, optimistisch, in paniek of juist gelaten? Verpleegkundigen kijken naar hoe familie met de patiënt of elkaar omgaat. En verpleegkundigen vragen zich af wat voor een patiënt ze voor zich hebben. Is dit iemand die met pijn en ongemak kan leven of is dit een patiënt die snel zijn of haar hoofd laat hangen? Anderzijds verdiepen verpleegkundigen zich in de individuele situatie en persoon van een patiënt door met een patiënt te praten. Vaak gebeurt dat impliciet, tussen de bedrijven door. Verpleegkundigen en patiënten brengen veel tijd met elkaar door. Daarbij wordt veel gepraat. Verpleegkundigen praten met patiënten omdat ze zich nu eenmaal in elkaars gezelschap bevinden. Dit praten is er ook op gericht informatie te verzamelen. Verpleegkundigen praten met patiënten over welke betekenis het ziek zijn voor hen heeft en hoe ze hun situatie ervaren, maar ook over allerlei schijnbaar triviale onderwerpen. Dat lijkt vaak gezellig geklets, maar hierdoor krijgen verpleegkundigen veel informatie over een patiënt. Door te praten over hun werk, het gezin, de stad of het dorp waar ze vandaan 
komen, hobby's en dergelijke, krijgen verpleegkundigen informatie over wat voor een persoon de patiënt is en hoe deze in het leven staat en gestaan heeft.

Verpleegkundige: "Wij weten vaak veel van mensen. Heel veel. En dan is dat niet omdat we zo nieuwsgierig zijn en graag alles willen weten. Ook wel natuurlijk (ha ha), maar het gaat erom dat je weet wie je voor je hebt." Verpleegkundigen verdiepen zich in de situatie en persoon van een patiënt door te observeren en te praten. Niet alleen impliciet, maar ook expliciet. Soms nemen verpleegkundigen expliciet de tijd om met patiënten te praten over hun situatie. Bijvoorbeeld wanneer een patiënt pas op de afdeling is opgenomen, dan nemen verpleegkundigen de tijd om met hem of haar te praten om informatie te geven en te verzamelen. Een laatste manier die verpleegkundigen inzetten om een totaalplaatje te maken is door met elkaar en andere zorgverleners te overleggen. Verpleegkundigen leggen informatie die zij verzamelen en relevant vinden in het kader van de zorgverlening in de schriftelijke rapportage vast. Drie keer per dag wordt deze doorgesproken, tijdens verpleegkundige overdrachten. Om 8.30 uur gebeurt dat het meest uitgebreid en zijn er soms ook andere zorgverleners aanwezig. Tijdens deze overdrachten wordt informatie uitgewisseld om een beeld te krijgen van patiënten en hun vragen en problemen.

\section{Individuele kennis als zoeklicht}

Hoe aan zorgbehoeften van patiënten tegemoet gekomen kan worden is niet altijd even duidelijk. Daarom maken verpleegkundigen gebruik van individuele kennis. Deze kennis van de specifieke situatie en persoon van een patiënt wordt door verpleegkundigen gebundeld om een totaalbeeld te maken. Dit totaalbeeld is uitgangspunt voor het interpreteren en beantwoorden van zorgbehoeften op een specifiek moment. Individuele kennis wordt gebruikt om op een bepaald moment in te kunnen schatten wat een patiënt nodig heeft om de situatie draaglijker te maken.

Verpleegkundige: "En dat je dan voor jezelf kunt kijken 'wat heeft een patiënt op welk moment nodig, precies afhankelijk van datgene wat hij, waar hij problemen mee ervaart of te verwachten problemen. Want vaak kan een patiënt geen problemen hebben, maar door de behandeling zijn er te verwachten problemen, fysiek gezien, maar ook als ze langer komen mentaal gezien. psychisch gezien."

Om behoefte aan zorg te zien is het volgens verpleegkundigen nodig om zicht te hebben op hoe een patiënt 'normaal' gesproken is en reageert. Van daaruit kunnen afwijkingen worden geconstateerd, waaruit zorgbehoeften kunnen worden afgeleid. 
Verpleegkundige: "Je krijgt als verpleegkundige soms wel eens rare antwoorden en dan weet je al hoe laat het is. Je kent de patiënt natuurlijk al langer en dan heb je ze nooit zo meegemaakt en dan weet je hoe laat het is." In deze paragraaf is besproken hoe verpleegkundigen werken aan onzekerheid. Ze maken gebruik van verschillende soorten kennis om situaties van onzekerheid zo veel mogelijk te voorkomen. Abstracte kennis van ziektebeelden en behandelingen en ervaringskennis van deze specifieke patiëntencategorie worden ingezet om op een bepaald momenten zorgbehoeften te interpreteren. Bovendien creëren verpleegkundigen met elkaar een totaalbeeld van een individuele patiënt om begrip voor hem of haar te krijgen en daardoor op een specifiek moment in te kunnen schatten wat iemand nodig heeft om het leven zo draaglijk mogelijk te maken. Tot besluit van deze paragraaf komt aan de orde dat verpleegkundigen werken aan een vertrouwensband, om onzekerheid over de vraag 'hoe goed te doen' zo veel mogelijk te voorkomen.

\section{Werken aan een vertrouwensband}

Verpleegkundigen werken aan een vertrouwensband met een patiënt omdat deze nodig is om een individueel beeld van een patiënt te creëren. In deze paragraaf wordt belicht wat volgens verpleegkundigen het belang van deze relatie is. Bovendien komt aan de orde dat verpleegkundigen meer nodig hebben dan alleen bepaalde vaardigheden om een relatie aan te gaan en te onderhouden.

\section{Belang van een relatie}

Verpleegkundigen geven aan dat het om verschillende redenen van belang is een vertrouwensband met een patiënt aan te gaan. In het vorige hoofdstuk is besproken dat een relatie tussen een verpleegkundige en een patiënt nodig is, omdat patiënten met een type problemen worden geconfronteerd dat daarom vraagt. Met een patiënt praten over wat het betekent om ernstig ziek te zijn en misschien wel dood te gaan, kan niet zonder als mens betrokken te. raken. Daarnaast geven verpleegkundigen van afdeling to aan dat een vertrouwensband met een patiënt nodig is om een totaalbeeld te creëren. Sommige informatie over de situatie en persoon van een patiênt kan door verschillende verpleegkundigen verzameld worden. Andere informatie is echter zo persoonlijk en ingrijpend voor patiënten, dat ze deze niet met iedereen. kunnen delen.

Verpleegkundige: "Ik denk dat het goed is als een patiënt en een verpleegkundige een wat betere relatie hebben. Dan kun je met patiënten ook meegaan met hun dingen. Dan vertellen ze ook waar ze mee bezig zijn." 
Verpleegkundige: "Het goede aan de zorg voor deze mevrouw is dat we een vertrouwensband hebben. Die kwam vrij snel tot stand. Van daaruit kan ik. dus dingen doen: informatie geven, of juist even wachten met informeren,

kijken welk momenten het meest geschikt zouden zijn om dingen te vertellen of dingen te doen. Daardoor is het soepel, redelijk verlopen ja."

Verpleegkundigen gaan ervan uit dat een vertrouwensband nodig is om voor patiënten te kunnen zorgen op een manier die aansluit bij hun specifieke vragen en problemen. Wanneer je iemand niet goed kent, is het moeilijk in te schatten welke problemen iemand ervaart en hoe hieraan tegemoet gekomen kan worden op een manier dat het leven voor deze patiënt zo draaglijk mogelijk wordt.

\section{Relatie aangaan}

Een relatie tussen een verpleegkundige en patiënt komt niet vanzelf tot stand. Dat vraagt om investering, zowel van verpleegkundigen als van patiënten.

In het denken en handelen van verpleegkundigen is zichtbaar dat er op de eerste plaats een bereidheid moet zijn als mens betrokken te raken in een relatie.

Verpleegkundige: "Ik denk dat je als mens, dat jezelf ook moet willen om contact te maken. Dat je betrokken moet willen raken en bereid moet zijn iets van jezelf te geven."

Verpleegkundigen moeten als mens bereid zijn tot contact. Bovendien is in het denken en handelen van verpleegkundigen zichtbaar dat ze over een aantal vaardigheden moeten beschikken om een vertrouwensband met een patiënt aan te gaan.

Verpleegkundige: "Het belangrijkste is dat je kunt luisteren. Dat je echt, ja echt een patiënt kunt laten praten. Dat je aan iemand kunt aflezen wat hij denkt en wat hij voelt en dat je ook het."

Verpleegkundige: "Belangrijk is dat je je kunt inleven in mensen."

Verpleegkundige: "Wat zeker niet onbelangrijk is zijn contactuele eigenschappen van mensen. En je moet een positieve uitstraling hebben en open staan voor mensen. Je moet toegankelijk zijn. Dat is het allerbelangrijkste. Dan krijgt je een soort vertrouwensband."

Voor verpleegkundigen die niet over relationele vaardigheden beschikken, zou volgens verpleegkundigen geen plaats moeten zijn in de zorg.

Verpleegkundige: "Als je dat niet kunt, als je niet met mensen kunt omgaan, luisteren, inleven, dan heb je hier niets te zoeken."

In het denken en handelen van verpleegkundigen is zichtbaar dat niet alleen zij bereid moeten zijn om een relatie aan te gaan, maar dat dit ook geldt voor de patiënt. Ook van de patiënt wordt verwacht dat deze investeert in een relatie. 
Verpleegkundige: "Patiënten moeten daar natuurlijk wel open voor staan. Meestal is dat ook wel zo. Niet met iedereen natuurlijk. Maar meestal hebben patiënten wel verpleegkundigen waarmee ze een betere band aangaan." Volgens verpleegkundigen is het beter wanneer patiënten een vertrouwensband met een aantal verpleegkundigen opbouwen, omdat verpleegkundigen vrij kunnen hebben of op vakantie kunnen zijn.

Verpleegkundige: 'Dat moet eigenlijk liever niet één verpleegkundige zijn, want die heeft ook soms geen dienst, is op vakantie of wat dan ook. Het zou goed zijn als een patiënt een breder kringetje om zich heen verzamelt met wie hij een wat betere band heeft."

Persoonlijke voorkeuren van patiënten spelen een rol bij het aangaan van een relatie met een verpleegkundigen. Ze maken keuzes bij het investeren in contact.

Verpleegkundige: "Ik denk dat het met bepaalde karakters te maken heeft. Je hebt patiënten die hebben graag die karakters van verpleegkundigen of die personen. Dat merk je wel. Dat hoor je ook, patiënten vertellen dat. Ze zijn meestal heel open tegen je. En dan zeggen ze 'ik heb liever die of die'." Verpleegkundige: "Ik vind het heel belangrijk dat een patiënt zijn eigen personen eruit haalt om een gesprek mee te voeren. Dat patiënten dat zelf uitkiezen. En ik heb daar ook absoluut geen moeite mee als het Vera of Theo is of wie dan ook. Ik vind het heel prettig als ze mij uitkiezen en soms is het ook zo dat je met meerdere verpleegkundigen bij een patiënt staat te praten. Maar dan heeft die patiënt de behoefte om dat te doen."

Niet alleen patiënten hebben hun persoonlijke voorkeuren, dat geldt ook voor verpleegkundigen.

Verpleegkundige: "Soms heb je natuurlijk eens een minder goed contact. Dat je zegt 'het kan beter'. Je hebt altijd wel eens patiënten, met wie het niet zo klikt. Dat is bij mij wel eens voorgekomen bij een man, echt, daar kon ik niet goed mee opschieten. Omgekeerd ook niet. Hij zat altijd maar te mopperen. Toen heb ik aangegeven dat ik dus niet meer bij die meneer op de kamer wilde staan en dan wordt daar wel rekening mee gehouden. lk voelde me daar niet gelukkig mee, maar ja. Niet zo professioneel ook, maar ja."

Soms klikt het niet tussen een verpleegkundige en een patiënt. Dat zou volgens verpleegkundigen vanuit professioneel gezichtspunt niet voor mogen komen. Toch is dat het geval, omdat verpleegkundigen als mens betrokken zijn bij de zorg. Dit probleem wordt volgens verpleegkundigen ondervangen omdat zij onderling verschillend zijn en daarom met andere patiënten een goed contact kunnen hebben.

Verpleegkundige: "Ik denk dat het goed is als een patiënt en een verpleegkundige een wat betere relatie hebben. En je kunt niet met alle patiënten zo'n relatie hebben. Maar het is goed als ik het heb met Jan en jij met Piet." 
In het voorafgaande is besproken dat individuele verpleegkundigen en patiënten ieder een aandeel hebben in het tot stand komen van een relatie. Een verpleegkundige moet bereid zijn een relatie aan te gaan en moet over een aantal relationele vaardigheden beschikken. Een patiënt moet bereid zijn tot persoonlijk contact. Bovendien heeft het tot stand komen van een relatie te maken met de persoonlijkheden van verpleegkundigen en patiënten. Soms klikt het wel en soms klikt het niet.

\section{Relatie organiseren}

Verpleegkundigen hebben niet alleen relationele vaardigheden nodig om een vertrouwensband te creëren. Daarvoor is meer nodig. Op de afdeling is een cultuur nodig, waarin het belang van een relatie voor de zorg wordt onderkend. Individuele verpleegkundigen moeten tijd en energie kunnen steken in een relatie.

Verpleegkundige: "Wat ik fijn vind op deze afdeling is dat je niet met scheve ogen wordt aangekeken als je eens met iemand zit te praten terwijl het eigenlijk heel druk is op de afdeling. Dan weet ik dat anderen niet denken 'die zit te luieren', maar dat ze ook weten en dat ook vinden dat ik ook druk bezig ben. Alleen niet met mijn handen, maar dat dat voor patiënten ook heel belang.

rijk is. Dat vindt dan gelukkig iedereen'."

Om met patiënten te kunnen praten en een relatie op te kunnen bouwen, moet er ook een cultuur zijn op de afdeling die dat toestaat. De afdeling moet bovendien zo georganiseerd zijn dat patiënten een aantal verpleegkundigen beter kunnen leren kennen. Bij het verdelen van patiënten in het kader van de zorg, wordt niet alleen rekening gehouden met het aantal gediplomeerden en het aantal leerlingen. Ook wordt er rekening mee gehouden dat een zelfde verpleegkundige een aantal dagen achter elkaar voor dezelfde patiënten kan zorgen.

Verpleegkundige: "Bij de werkindeling wordt er rekening mee gehouden dat verpleegkundigen bepaalde patiënten langere tijd kunnen verplegen. En dat merk je ook aan de mensen. Als je in het begin komt is het wat aftasten, maar dat verandert als je dan de dagen daarna weer komt of zeven dagen achter elkaar werkt. Vaak zeg ik dat ook tegen de mensen."

De manier waarop zorg wordt verdeeld, draagt ertoe bij dat verpleegkundigen en patiënten elkaar beter kunnen leren kennen. Wanneer verpleegkundigen er tijdens overdrachten achter komen dat niemand van hen goed contact met een patiënt heeft, proberen ze dat expliciet te regelen.

Verpleegkundige: "Belangrijk is te weten waar mensen mee bezig zijn. Meestal is dat iets wat je met z'n allen bespreekt in het team. Of er mensen zijn die wel met die patiënt contact hebben. En dat hoef je niet zelf te zijn. Je hoeft niet met iedereen een goed contact te hebben. Maar heeft de patiënt met niemand con- 
tact, dan moeten we daar waarschijnlijk iets aan doen. En dan is er altijd wel eentje die zegt van 'goh, ja, ik zou dat wel willen proberen, ik ga er wel eens mee praten of eens met de familie praten of hij aan hen wel dingen zegr'."

Verpleegkundigen praten in teamverband over de vraag of éen van hen in staat is een zodanige relatie met een patiënt aan te gaan, dat een patiënt kan vertellen wat hem of haar bezig houdt en waar zich problemen voordoen. Soms worden er ook andere hulpverleners bij betrokken, wanneer gedacht wordt dat patiënten zich bij hen beter kunnen uiten.

Verpleegkundige: "En is er niemand die contact heeft dan vraag je het aan de arts of zij contact hebben met die patiënt. Of de patiënt hem kan vertellen wat hen bezighoudt. Of een maatschappelijk werkster. Je kunt zo veel mensen erbij betrekken."

In het voorgaande is besproken dat verpleegkundigen een vertrouwensband belangrijk vinden om te achterhalen wat een patiënt op een bepaald moment nodig heeft. Vorm geven aan deze relatie vraagt zowel om investering van de verpleegkundige als van de patiënt. Verpleegkundigen moeten bereid zijn om als mens betrokken te raken en moeten over bepaalde vaardigheden beschikken. Patiënten moeten bereid zijn tot contact. De vraag wie met wie een relatie opbouwt is veelal afhankelijk van persoonlijke karakteristieken van zowel verpleegkundigen als patiënten. Opbouwen van een band met een patiënt vraagt ook om andere voorwaarden, zoals een cultuur op de afdeling die het belang van een relatie onderkent en een vorm van werkverdeling die contact tussen verpleegkundigen en patiënten in de hand werkt. Soms worden er andere zorgverleners bij betrokken, wanneer men ervan uitgaat dat deze beter in staat zijn een vertrouwensband met een patiënt aan te gaan.

\section{ZOEKEN NAAR EEN UITWEG}

In het voorafgaande is belicht hoe verpleegkundigen situaties proberen te voorkomen, waarin ze niet weten hoe goed te doen voor patiënten. Wanneer dat op een bepaald moment toch gebeurt, proberen verpleegkundigen op verschillende manieren door te gaan met zorgen. In contact met patiënten en in overleg met collega's wordt gezocht naar een uitweg.

\section{Ruimte creëren}

Wanneer voor verpleegkundigen op een bepaald moment onduidelijk blijft wat een patiënt van hen vraagt, gaan ze evvoor zitten om dit te achterhalen. Verpleegkundigen proberen daardoor ruimte voor patiënten te creëren om expliciet hun behoefte aan zorg te uiten. 


\section{Verpleegkundige: "En dan zeg ik'nu moet u me toch eens vertellen wat er aan} de hand is'. Dan probeer ik toch mensen aan de praat te krijgen, als ik denk dat ze ergens mee zitten."

Verpleegkundigen proberen patiënten de ruimte te geven om te vertellen waar ze op een bepaald moment problemen mee ondervinden. Daarbij benoemen verpleegkundigen soms ook expliciet wat ze denken, om patiënten te stimuleren naar voren te brengen waar ze behoefte aan hebben.

Verpleegkundige: "Vroeger durfde ik dat niet. Nu doe ik dat gewoon en dat moet je ook kunnen. Als iemand blij is, dan is het gemakkelijk om te vragen van 'goh, waarom bent $u$ blij. $U$ ziet er zo stralend uit?. Wanneer een patiënt verdrietig is, moet je ook het lef hebben daarnaar te vragen."

Door bijvoorbeeld gevoelens bespreekbaar te maken, proberen verpleegkundigen patiënten te stimuleren om te vertellen waar ze zich zorgen over maken, welke problemen ze ondervinden en welke zorg ze nodig hebben om zich wat beter te voelen.

\section{Aftasten en uitproberen}

Wanneer op een bepaald moment toch onduidelijk blijft waar een patiënt behoefte aan heeft, tasten ze af en proberen van alles uit om te achterhalen wat een patiënt nodig heeft om de situatie als draaglijker te ervaren. Dat doen ze op verschillende manieren. Bijvoorbeeld door een gesprek op gang te brengen.

Verpleegkundige: "Soms weet je het gewoon niet. Wat je dan doet is een balletje opgooien. Kijken hoe iemand reageert."

Soms wordt naar aanknopingspunten gezocht, om te achterhalen waar een patiënt behoefte aan heeft.

Verpleegkundige: "Die man is nu hier voor de derde chemokuur. Hij is een aantal dagen geleden opgenomen. Hij had in zijn thuissituatie zijn Hickmann verloren omdat hij trombose had. Dus hij heeft een nieuwe Hickmann gekregen, waardoor de chemo twee dagen is uitgesteld. Ja, die man heeft het op het moment heel erg moeilijk gekregen. Gisteren eigenlijk. Het was nogal problematisch gegaan met het inbrengen van de Hickmann. En vanmorgen begon hij opeens te huilen. Toen ik binnenkwam en ik zei 'hoi, goedemorgen' begon hij te huilen. En toen zei hij 'als mensen vriendelijk tegen me zijn vandaag, daar kan ik niet tegen, moet ik huilen'. Ik heb er even rustig bij gezeten. En toen verontschuldigde hij zich. Ik zei 'waarom verontschuldigt u zich nou? Daar hoef je je niet voor te verontschuldigen'. En toen kwam het gesprek eigenlijk op gang. Toen kwam het er allemaal uit. Op een gegeven moment kwam eruit dat het hem pijn deed dat hij de derde kuur kreeg."

Deze verpleegkundige reageert op een onverwachte situatie. Een patiënt begint plotseling te huilen. Hij probeert te achterhalen waar deze patiënt last van ondervindt en welke behoeften aan zorg daarmee samenhangen. $\mathrm{Hij}$ 
vraagt waarom de patiënt zich verontschuldigt voor zijn huilbui. Dat bliikt een goed aanknopingspunt, zowel om zorgbehoeften te achterhalen als om er adequaat en betekenisvol op te reageren.

\section{Overleggen met collega's}

Wanneer zorgbehoeften van patiënten onduidelijk blijven overleggen verpleegkundigen met collega's. Ze overleggen met elkaar om een beeld te krijgen van vragen en behoeften van een patiënt op een specifiek moment. Soms kunnen ze het daarover niet eens worden. Zoals in paragraaf $\mathrm{I}$ aan de orde is gekomen, bijvoorbeeld omdat verpleegkundigen verschillende inzichten hebben over de vraag welke zorgbehoefte een patiënt heeft en hoe daarop gereageerd kan worden. Om te achterhalen wat op dat moment een adequaat en betekenisvol antwoord is verrichten verpleegkundigen in overleg met collega's verschillende activiteiten. Verpleegkundigen blijven bijvoorbeeld voortdurend met elkaar in gesprek wanneer het niet lukt zorgbehoeften te interpreteren en erop te reageren.

Verpleigkundige: "We moeten het toch weer over $\mathrm{x}$ hebben. Ik ben nog steeds niet tevreden over hoe het loopt. Ik heb het gevoel dat $x$ het moeilijk heeft en we er niet goed iets aan kunnen doen. Daar moeten we toch verandering in kunnen brengen? Vinden jullie toch niet dat we moeten proberen voor haar meer ruimte te creëren, door haar moeder wat meer buiten de deur te houden?"

Wanneer zich situaties voordoen waarin verpleegkundigen niet weten hoe ze adequaat en betekenisvol op zorgbehoeften moeten reageren, dan komen ze daar bij iedere overdracht weer op terug. Ze blijven in gesprek, op zoek naar een antwoord. Een andere manier om te zoeken naar een passend zorgantwoord is door andere zorgverleners erbij te betrekken, zoals in de hierboven genoemde situatie het geval was.

Verpleegkundige: "Dat hebben we in het team besproken en ook buiten het team met een psycholoog en maatschappelijk werkster. En die hadden zoiets 'dat is een moeder-dochter verhouding, daar moet je vanaf blijven', maar van de andere kant wel proberen ruimte voor haar te creëren. We hebben nu samen met hen een dagschema voor haar afgesproken, waarbij ze dus fysiotherapie kriigt, activiteiten therapie, rustuurtie, wasuurtie, zoiets allemaal, zodat ze dus constant bezig moet zijn. Tegen haar moeder hebben we gezegd dat ze moet proberen toch wat later te komen op een dag, zodat dan 's morgens de activiteiten kunnen plaatsvinden. En eigenlijk gaat het nu hecl goed. Maar we zijn dat nog steeds aan het bespreken. ledere week evalueren we nu hoe het gaat."

Andere zorgverleners worden erbij betrokken om een adequaat en betekenisvol antwoord te kunnen geven op specifieke zorgbehoeften van patiënten. 
Wanneer verpleegkundigen - al dan niet in samenspraak met andere zorgverleners - niet kunnen achterhalen wat een passend antwoord is, dan wordt een gezamenlijke aanpak afgesproken.

Verpleegkundige: "Je zult toch op een gegeven moment één bepaalde lijn moeten volgen. Wat ik eerder zei, over dat meisje bijvoorbeeld. We proberen nu toch allemaal op een lijn te zitten, verpleegkundigen onder elkaar. Hoe moeilijk het vaak ook is, toch proberen een standpunt vast te houden. Ook al sta je daar als persoon niet helemaal achter, moet je dat toch doen als het voor haar het beste is. Je doet het voor haar."

Wanneer het niet lukt om zorgbehoeften op zodanige manier te interpreteren dat iedereen zich daarin kan vinden, wordt een gezamenlijke aanpak afgesproken. Verpleegkundigen doen dat als ze er van uit gaan dat een verschillende aanpak de situatie voor een patiënt minder draaglijk zal maken.

In deze paragraaf is besproken hoe verpleegkundigen reageren op situaties waarin onduidelijk is wat een patiënt nodig heeft om het bestaan als draaglijker te ervaren. Wanneer in een specifieke situatie niet duidelijk is waar een patiënt behoefte aan heeft ondernemen verpleegkundigen allerlei activiteiten, zowel in relatie tot patiënten als in overleg met collega's. In relatie tot patiënten proberen ze voor hen ruimte te creëren, zodat zij hun behoefte aan zorg kunnen uiten. Ze tasten de situatie voorzichtig af bij een patiënt en snijden allerlei onderwerpen aan, om te achterhalen wat een patiënt nodig heeft om de situatie als draaglijker te ervaren. In overleg met collega's proberen ze een passend antwoord te vinden op een zorgbehoefte van een patiënt of ze maken met hen afspraken wanneer onduidelijkheid blijft bestaan.

\section{CONCLUSIE}

In dit hoofdstuk zijn morele ervaringen van verpleegkundigen besproken vanuit een specifieke invalshoek. Door te zoeken naar situaties waarin verpleegkundigen moeilijkheden, problemen of belemmeringen ervaren bij het tegemoetkomen aan zorgbehoeften van patiënten, is onzekerheid aan het licht gebracht. In dit hoofdstuk is besproken dat verpleegkundigen onzekerheid ervaren, wat de aard van deze onzekerheid is en hoe ze deze proberen te hanteren.

Verpleegkundigen werken in onzekerheid omdat zorgbehoeften om interpretatie vragen. Het is niet altijd duidelijk welke vragen en behoeften een patiënt heeft. Patiënten zeggen iets of vertonen bepaald gedrag waaruit verpleegkundigen zorgbehoeften moeten afleiden. Op de tweede plaats ervaren verpleegkundigen onzekerheid omdat ze zelf invloed hebben op de vorm die zorgbehoeften aannemen. Ze zijn zich daarvan bewust en vragen zich 
daarom af of deze invloed wel goed is. Op de derde plaats is zorg onzeker omdat er verschillende inzichten mogelijk zijn over de manier waarop de situatie voor een patiënt draaglijker gemaakt kan worden. Verpleegkundigen kunnen daar verschillende opvattingen over hebben. Dat kan tot onzekerheid leiden, omdat niet meer duidelijk is hoe goed te doen voor een patiënt. Op de vierde plaats is zorg inherent onzeker omdat de situatie van een patient voortdurend verandert. Zowel de fysieke, emotionele en sociale situatie kunnen veranderen, als ook de patiënt als persoon. Verpleegkundigen moeten zich daarom in ieder patiëntencontact afvragen welke patiënt ze voor zich hebben en hoe op dat moment de draaglijkheid van het bestaan kan worden bevorderd.

Om te verhinderen dat onzekerheid de overhand krijgt, gebruiken verpleegkundigen verschillende soorten kennis en vaardigheden. Onduidelijkheid over de vraag hoe de situatie voor patiënten draaglijker gemaakt kan worden, wordt zo veel mogelijk voorkomen door het verzamelen en gebruiken van abstracte en individuele kennis. Bovendien werken verpleegkundigen aan een relatie met een patiënt, omdat ze ervan uitgaan dat binnen deze relatie zicht verkregen kan worden op de vraag wat een patiënt nodig heeft om de situatie draaglijker te maken. Wanneer zich situaties van twijfel voordoen, dan reageren verpleegkundigen daarop door voor patiënten op specifieke momenten ruimte te creëren om zorgbehoeften te uiten, door voorzichtig de situatie af te tasten en door allerlei onderwerpen aan te snijden om vragen en problemen voor het voetlicht te brengen. Ook overleggen verpleegkundigen met elkaar om zo veel mogelijk duidelijkheid te krijgen over de vraag wat een patiënt nodig heeft om de situatie zo draaglijk mogelijk te maken. Soms worden concrete afspraken gemaakt, om te kunnen zorgen en niet in een impasse te raken.

In hoofdstuk 4 zijn morele ervaringen van verpleegkundigen met dagelijkse zorgverlening belicht, door te bespreken aan welke zorgbehoeften van patiënten ze proberen tegemoet te komen en door te bespreken hoe ze dat doen. Daar is aan de orde gekornen dat verpleegkundigen activiteiten verrichten om de situatie voor patiënten zo draaglijk mogelijk te maken. Verpleegkundigen bieden niet alleen emotionele steun, maar verrichten ook technische, praktische en organisatorische activiteiten of zijn eigenwijs en assertief. In dit hoofdstuk zijn morele ervaringen van verpleegkundigen verder uitgediept door te laten zien dat ze werken met onzekerheid. Zorg is inherent onzeker. Om te weten waar een patiënt behoefte aan heeft om de situatie zo draaglijk mogelijk te maken, wordt daarom gebruik gemaakt van abstracte en individuele kennis en wordt gewerkt aan een relatie met een patiënt. 
In het volgende hoofdstuk zal nog een andere kant van morele ervaringen van verpleegkundigen worden belicht. Er worden een aantal situaties besproken waarin zorg voor de patiënt onder spanning komt te staan. 


\section{HANTEREN VAN SPANNINGEN}

In dit hoofdstuk worden morele ervaringen van verpleegkundigen besproken aan de hand van situaties waarin de zorg die zij aan patiënten geven onder spanning staat. Om inzicht te krijgen in morele ervaringen van verpleegkundigen is gezocht naar situaties waarin zij moeilijkheden, problemen en/of belemmeringen ervaren, wanneer ze proberen de situatie voor patiënten zo draaglijk mogelijk te maken. Daarbij zijn in het denken en handelen van verpleegkundigen situaties geïdentificeerd waarbij tegemoet komen aan zorgbehoeften van patiënten onder druk staat. Dergelijke situaties zijn op verschillende plekken gelokaliseerd.

In paragraafl komt aan de orde dat verpleegkundigen soms niet die zorg aan patiënten kunnen geven die ze zouden willen geven, omdat patiënten daar zelf anders over denken. In hoofdstuk 4 zijn situaties beschreven waarin verpleegkundige en patiënt het eens waren over de wijze waarop de situatie draaglijker kon worden. Soms is dat echter niet het geval en is er sprake van een meningsverschil tussen verpleegkundige en patiënt over wat goed is om te doen. In paragraaf 2 komen situaties aan de orde waarin de zorg die zij aan patiënten willen geven onder druk staat als gevolg van behandelbeleid van artsen. In hoofdstuk 4 is de zorg die verpleegkundigen geven besproken alsof deze los staat van zorg van andere hulpverleners. Dat is niet het geval. Met name artsen hebben invloed op de ruimte die verpleegkundigen hebben om de situatie voor patiënten draaglijker te maken. In paragraaf 3 komt de spanning aan de orde die ontstaat omdat verpleegkundigen ook voor zichzelf moeten zorgen, waardoor zorg voor individuele patiënten onder druk kan komen. In paragraaf 4 tenslotte wordt besproken dat de zorg die verpleegkundigen aan individuele patiënten kunnen geven, beperkt kan worden door de context van de afdeling.

\section{Meningsverschillen met patienten}

In deze paragraaf worden situaties besproken waarin de zorg die verpleegkundigen aan individuele patiënten willen geven onder spanning komt te staan, doordat patiënten andere ideeën hebben over de inhoud van de zorg dan zijzelf. Patiënten vragen soms iets dat volgens verpleegkundigen een 
draaglijk bestaan uiteindelijk in de weg staat. In deze paragraaf worden dergelijke meningsverschillen besproken aan de hand van situaties waarin ver. pleegkundigen er van uit gaan dat patiënten bepaald gedrag vertonen dat hun lichamelijke conditie ondermijnt. Daarbij wordt belicht hoe verpleegkundigen deze meningsverschillen hanteren.

\section{Zoeken naar overeenstemming}

Eén situatie die zich op afdeling to regelmatig voordoet en waarin sprake is van vragen van patiënten die volgens verpleegkundigen een draaglijk bestaan uiteindelijk niet ten goede komen, heeft te maken met het bevorderen of op peil houden van de lichamelijke conditie van patiënten. Verpleegkundigen besteden hieraan veel tijd omdat de behandeling meer kans van slagen heeft wanneer patiënten in een optimale lichamelijke conditie zijn.

Verpleeghitundige: "Je moet er goed op letten dat mensen voldoende bewegen.

Bij onvoldoende beweging doen zich complicaties voor, zoals trombose, slechter lopen. Dan probeer ik ze toch hun bed uit te krijgen. Je moet ze proberen te motiveren om te gaan wandelen."

Verpleegkundige: "Mensen zijn soms niet vooruit te branden. Die willen alleen maar in bed blijven liggen. Daar moet je wel wat voor doen, om hen eruit te krijgen, want dat is niet goed voor hun gezondheid en behandeling." In de dagelijkse zorgverlening kan het bevorderen of op peil houden van de lichamelijke conditie haaks staan op vragen van patiënten. Een patiënt wil bijvoor beeld niet uit bed omdat hij zich beroerd en ellendig voelt, terwijl een verpleegkundige vindt dat dit nodig is om decubitus te voorkomen. Een patiënt wil zijn pillen niet slikken, terwijl een verpleegkundige dat belangrijk vindt om infecties tegen te gaan. Een patiënt wil niet eten of drinken, terwijl een verpleegkundige dat noodzakelijk vindt om zijn algehele lichamelijke conditie te versterken. Wanneer er meningsverschillen zijn met patiënten over wat goed is om te doen op een bepaald moment, dan verrichten verpleegkundigen verschillende activiteiten om overeenstemming te bereiken.

\section{Wederzijds begrip creëren}

Eén manier waarop verpleegkundigen proberen met patiënten tot overeenstemming te komen is door wederzijds begrip te creëren. Dat doen ze als volgt. Wanneer patiënten iets van hen vragen, waarvan zij denken dat dit uiteindelijk de situatie voor patiënten niet draaglijker zal maken, proberen ze inzicht te krijgen in gevoelens en ervaringen van patiënten en begrip te krijgen voor hun opvattingen van goede zorg op dat moment. Ze proberen te achterhalen wat het voor een patiënt betekent om zich te moeten wassen, uit bed te komen of 
pillen te slikken. Ze willen begrijpen waarom dit door patiënten soms als ondraaglijk wordt ervaren.

Verpleegkundige: "Je kunt wel van alles willen, maar je moet daarbij wel rekening houden met de patiënt. Hoe hij dat ervaart. Soms willen patiënten iets niet, omdat ze niet kunnen. Het is vaak niet zo zeer een kwestie van niet willen, maar van niet kunnen."

Verpletgkundige: "Dan vraag ik ook altijd aan patiënten 'wat maakt het voor u dan zo moeilijk'?."

Verpleegkundigen proberen te achterhalen waarom een patiënt iets van hen vraagt. Waarom is het voor hem of haar zo moeilijk om bepaald gedrag te vertonen? Welke gevoelens, emoties en ervaringen hangen daarmee samen? Wanneer verpleegkundigen begrip hebben voor de situatie van een patiënt, veranderen ze soms ook van mening.

Verpleegkundige: "en dan zeg ik 'ik snap wat u bedoelt, dan doen we het zoals u het wilt'."

Verpleegkundigen proberen in situaties dat zich meningsverschillen voordoen, zicht te krijgen op de redenen waarom het voor patiënten moeilijk is bepaald gedrag te vertonen. Ze houden daar in hun handelen rekening mee. Daarnaast proberen verpleegkundigen ook begrip te krijgen van patiënten, voor hun eigen opvattingen over wat goed is om te doen op een bepaald moment. Door informatie te verstrekken proberen ze begrip te creëren voor hun opvatting dat het gezonde bestaan door bepaalde handelingen wordt beïnloed.

Verpleegkundige: "Daar heb ik het dan over met zo'n patiënt. Dan probeer ik uit te leggen hoe wij denken. En dat het niet is van 'we willen je waswerk niet doen, helemaal geen zin in, het is te druk, je moet dat allemaal zelf kunnen'. Dan probeer ik duidelijk te maken dat het voor hem gewoon veel beter is. En hoop ik maar dat dat aankomt. Er zijn ook keren dat ze dat dan niet begrijpen. Ik probeer meestal ook, als ze dan toch niet willen, om een kleine middenweg te zoeken."

Door het creëren van wederzijds begrip trachten verpleegkundigen met patiënten tot overeenstemming te komen.

\section{Motiveren, stimuleren, overtuigen en overhalen}

Een andere manier waarop verpleegkundigen proberen met patiënten tot overeenstemming te komen, is door invloed op hen uit te oefenen. $\mathrm{Zij}$ proberen patiënten te stimuleren, te motiveren, te overtuigen of over te halen tot bepaald gedrag, door bijvoorbeeld door patiënten informatie te verstrekken.

Verpleegkundige: "Bij opname vertel je patiënten waarom het belangrijk is dat ze zich goed wassen: om ailerlei infecties te voorkomen. We geven hen betadine zeep, waarmee ze zich moeten wassen. Daarnaast vertellen we hen ook 
waarom het beter is geen crème of body lotion te gebruiken, lenzen uit te doen. Mensen krijgen snel een infectie, dat moeten we zien te verkomen." Verpleegkundige: "Er zijn mensen die zeggen 'ik heb pijn in mijn keel, ik slik die pillen niet'. Daar leg ik me dan niet bij neer. Je kunt er ook heel veel aan doen om het voor mensen, zoals die meneer met keelpijn, wat makkelijker te maken. Maar je moet als verpleegkundige weten hoe belangrijk die medicijnen zijn. Ik bedoel, als ze ze twee of drie weken niet slikken, zitten ze met een schimmel. En daar zijn ze dan meer dan een half jaar mee zoet. En ik denk, als patiënten dat maar goed beseffen, dan doen ze dat ook. Je moet patiënten proberen te overtuigen om het dan wel te doen. Hoe moeilijk of pijnlijk dat dan ook is. En als ze dan eens een tabletje overslaan, ik bedoel, dat zal het um niet zijn. Maar gewoon grif zeggen van 'och ja u heeft ook zo'n pijn in de keel, laat maar', ja, dat heeft geen nut. Dat doe je niet voor de patiënt, om hem te pesten, die tabletten en noem maar op, al die dingen. En dat is vaak wel heel moeilijk, om ze te overtuigen. Je legt mensen daarom nog eens uit waarom het zo belangrijk is. En als je mensen dat dan nog eens hebt uitgelegd, dan snappen ze dat meestal wel en doen ze dat ook."

Verpleegkundigen trachten patiënten over te halen tot bepaald gedag door hen met informatie te overtuigen. Verpleegkundigen proberen patiënten soms ook over te halen door de consequenties van bepaald gedrag te benadrukken.

Verpleegkundigen: "Weet u zeker dat u niet even uit bed kunt? Heel even maar?' vraagt Dirk aan mevrouw $x$ als we op haar kamer zijn voor de dagelijkse verzorging. Vervolgens probeert hij haar uit bed te krijgen door te zeggen dat ze kans heeft op doorligplekken en dat is pijnlijk. Het is toch ook prettig om even bij het raam te zitten. Dat is voor ons ook makkelijker. Kunnen we snel even het bed opmaken."

Deze verpleegkundige benadrukt verschillende consequenties van "uit bed komen'. Hij vertelt de patiënt dat het voor haar fysieke conditie beter is, omdat ze minder kans op decubitus heeft. Hij vertelt haar dat decubitus pijnlijk is. Hij benadrukt ook de positieve consequenties. Hij vertelt haar dat de kans groot is dat ze zich prettiger voelt als ze even uit bed is. Bovendien legt hij niet alleen de nadruk op de positieve en negatieve consequenties voor de patiënt zelf, maar ook voor de verpleegkundigen. Hij probeert de patiënt als het ware over te halen, door haar voor te stellen iets te doen wat fijn is voor verpleegkundigen. Een andere manier waarop verpleegkundigen proberen patiënten te motiveren tot bepaald gedrag is door hen te herinneren aan het doel dat ze voor ogen hadden.

Verpleegkundig: "Dan zeg ik 'u wil toch cok graag weer naar huis'. Dat zeg ik dan soms tegen patiënten wanneer ze niet goed willen eten en drinken." Verpleegkundigen motiveren patiënten om goed te eten, te drinken, uit bed te komen of hun pillen goed te slikken, door hen eraan te herinneren dat ze 
uiteindelijk weer gezond naar huis willen. Soms ook proberen ze patiënten over te halen door aanlokkelijke omstandigheden te creëren.

Verpleegkundige: "Ja, ze moet toch gestimuleerd worden om te eten. Dat ze ook met andere patiënten aan tafel kan eten. 'Die buurvrouw die wil samen met je eten. Het eten is lekker'. Dat soort dingen."

Verpleegkundigen proberen patiënten te motiveren tot bepaald gedrag door de omstandigheden waarin dat gedrag moet worden vertoond voor patiënten aantrekkelijker te maken. Verpleegkundigen zoeken ook naar alternatieven om met patiënten tot overeenstemming te komen.

Verpleegkundige: "Hebt u misschien zin in pap mevrouw x? Zou dat er wel ingaan? Het is toch goed als u iets eet."

Soms heeft motiveren van patiënten meer de vorm van patiënten verleiden.

Verpleegkundige: "Ze vond het verschrikkelijk dat ze haar haren kwijtraakte. En dat heeft echt veel gepraat en gedoe gekost om haar haar eraf te mogen scheren. Want het werd echt zo vies op het laatst. Het viel zo verschrikkelijk. uit en dan zaten die haren echt overal. In haar eten, aan haar handen, ja dat viel gewoon de hele dag uit. En om dan toch, om haar dan toch zover te krijgen dat ze haar haar eraf liet scheren omdat dat toch beter was. Ja, dat heeft echt heel veel gepraat en heel veel overredingskracht gekost. Haar laten zien dat ze toch met een sjaal iets leuks kan maken. Dan hoefde ze niet de hele dag haar pruik op, want dat was dan weer te warm en dat vond ze lastig. En ze vond het eigenlijk ook een beetje zonde van een mooie pruik, want ze lag nog zoveel in bed. En als je dan zegt: 'je kunt met een sjaal ook leuke dingen doen, en vraag maar eens aan je echtgenoot of die een sjaal meeneemt, dan laat ik dat zien'. En nou ja, als je haar dan toch zo ver krijgt dat ze haar haar wat zo verschrikkelijk uitvalt, dat je dat dan mag afscheren, ja, dat vind ik dan, dan ben je toch goed bezig."

Patiënten die chemo krijgen hebben last van haaruitval. Sommige patiënten vinden het moeilijk het laatste beetje haar dat er nog is af te scheren. Verpleegkundigen gaan ervan uit dat dit van belang is voor een hygiënische orngeving. Deze verpleegkundige probeert een patiënt daarom over te halen haar laatste haren eraf te scheren. Door te benadrukken dat ze er leuker uitziet met een pruik of een sjaal, probeert deze verpleegkundige de patiënt te verleiden tot bepaald gedrag.

De manier waarop verpleegkundigen motiveren of overhalen tot bepaald gedrag is afhankelijk van de persoon van de patiënt en hoe deze zich voelt. Verpleegkundigen proberen daarom vooral van alles uit.

Verpleegkundige: "Je probeert eens wat. Stelt van alles voor. 'Eet eens aan tafel met uw kamergenoten. Is dat niet prettig?'. En als je dan merkt dat dat werkt, dan probeer je dat natuurlijk de volgende keer weer." 
Verpleegkundige: "Ik heb haar voorgesteld eens naar het restaurant te gaan om te eten. Misschien dat een andere omgeving motiverend werkt."

De keuze voor een bepaalde motiveringsactiviteit is volgens verpleegkundigen afhankelijk van de persoon van de patiënt en van de situatie waarin iemand verkeert. Sommige patiënten zijn graag in gezelschap van anderen, waardoor dit inderdaad stimulerend kan werken bij het eten, terwijl andere patiënten liever alleen zijn. Sommige patiënten kunnen uit bed, waardoor aan tafel eten een reële optie is. Andere patiënten kunnen niet uit bed en moeten daar dan ook eten. Hoe iemand gemotiveerd kan worden tot bepaald gedrag is afhankelijk van de persoon en situatie van een patiënt. Verpleegkundigen proberen daarom van alles uit om te achterhalen wat voor de betreffende patiënt motiverend kan werken om gedrag te vertonen dat de gezondheid bevordert.

\section{Zoeken naar een middenweg}

Activiteiten die verpleegkundigen verrichten om met patiënten tot overeenstemming te komen, leiden er vaak toe dat een middenweg wordt bewandeld.

Verpleegkundige: "En als we zeggen bijvoorbeeld een half uur en na een kwartiertje belt hij, en dan zeg ik 'oké'. Dan ben ik daar wel wat soepeler in. Maar proberen om hem toch te zeggen dat het goed is voor hem, het laten doordringen. Ik zeg dan 'ik kan wel toegeven aan uw wensen, maar daar wordt $u$ niet beter van'. Maar ik denk dat je ook wel, van de andere kant, moet je ook als je iets wil, zelf eens terugtrekken en zeggen van 'ja u heeft gelijk, nu doen we dat niet, ik laat wat $u$ wilt'. Ik denk dat dat ook heel vaak voorkomt en dat moet je ook respecteren vind ik, want de patiënt heeft ook dingen waarvan hij zegt ' $\mathrm{ik}$ wil dat nu niet, ik wil dat over een half uur'. Nou ja, oké, dan kom ik, als dat in mijn werk kan, over een half uur terug."

Verplecgkundige: "Ik spreek dat ook af met patiënten. Dān zeg ik 'zullen we het zo doen? De hele dag in bed dat kan echt niet, dat is niet goed voor u'. Dus dan probeer ik wat af te spreken met een patiënt. 'We doen nu wat u wil, maar dan doen we het straks zo'."

Verpleegkundigen zoeken naar een middenweg. Het wordt niet helemaal het gedrag dat de verpleegkundige voor ogen heeft en het is ook niet dat wat een patiënt op een bepaald moment vraagt. Er wordt een middenweg bewandeld die voor beiden acceptabel is. Niet een uur, maar een half uur. Vanmorgen uit bed, om decubitus te voorkomen. Vanmiddag in bed, omdat de patiënt zich beroerd en ellendig voelt.

Verpleegkundigen willen de gezondheid van patiënten bevorderen, maar ook rekening houden met ervaringen van patiënten. Wanneer patiënten iets willen of niet willen, dan heeft dit volgens verpleegkundigen te maken met hoe ze hun situatie ervaren. Daarom houden ze rekening met gevoelens, emoties en ervaringen van patiënten. Door op zoek te gaan naar overeenstem- 
ming en door een middenweg te bewandelen, wordt een situatie gecreëerd waarin beiden zich kunnen vinden.

\section{Conflicten vermijden}

Verpleegkundigen zoeken naar overeenstemming met patiënten over wat goed is om te doen. Dat doen ze niet alleen omdat ze rekening willen houden met vragen en ervaringen van patiẹnten, maar ook omdat ze conflicten willen vermijden. Daar hebben ze verschillende redenen voor.

Conflicten vermijden en zoeken naar overeenstemming met patiënten heeft tot doel de communicatie open te houden, waardoor de zorgrelatie in stand blijft. Zoals ik in de vorige hoofdstukken heb laten zien vinden verpleegkundigen een vertrouwensrelatie met patiënten een belangrijke voorwaarde voor zorg. Dit is de reden om met patiënten te zoeken naar overeenstemming en om conflicten te vermijden.

Verpleegkundige: "Ik probeer altijd te voorkomen dat het uitloopt op een ruzie met patiënten. Daar heb je niets aan. Dan kun je het helemaal wel vergeten. Als er ruzie is wordt het moeilijk om voor iemand te zorgen."

Verpleegkundige: "Ik denk ook dat je heel veel dingen, heel veel conflicten kunt voorkomen door gewoon duidelijk weer alles uit te leggen en zelf rustig te blijven. Ik denk maar altijd zo, als ik patiënt was, zou ik ook lastig zijn. Ik bedoel, als je ziek bent, ben je lastig, dat ben je ook zelf. Ik zou het zeker nooit tot een conflict laten escaleren."

Om de situatie voor patiënten draaglijker te maken, moeten verpleegkundigen zicht hebben op hun zorgbehoeften. Deze kunnen alleen duidelijk worden wanneer patiënten bereid zijn ze te uiten. In een situatie waarin er meningsverschil bestaat, wordt dat proces belemmerd. Overeenstemming is nodig om te kunnen zorgen.

\section{Conflicten hanteren}

Wanneer een meningsverschil ondanks allerlei pogingen van verpleegkiındigen dit te vermijden toch uitloopt op een conflict, dan gaan ze hier op verschillende manieren mee om.

\section{Zorguragen van patiënten negeren}

Soms negeren verpleegkundigen vragen van patiënten. Verpleegkundigen bepalen dan wat er gebeurt. Dat heeft tot gevolg dat ze fysieke dwang op patiënten uitoefenen, om hun opvattingen over wat goed is om te doen erdoor te drukken. Dat doen ze bijvoorbeeld door zorg van patiênten over te nemen, zoals patiënten tegen hun zin in uit bed zetten. 
Verpleegkundige: "Dan doe ik dat toch. als ik denk dat het nodig is in het kader van behandeling, dan doe ik toch wat ik wil."

Verpleegkundige: "Dan tillen we haar toch uit bed. Ook al stribbelt ze tegen en zegt ze dat ze niet wil. Dat moet dan toch. Als ze niet uit bed komt is de ramp niet te overzien."

Verpleegkundigen oefenen soms dwang op patiënten uit door gedragsmogelijkheden te blokkeren.

Verpleegkundige: "Een mevrouw met gemetastaseerde borsten, dat is nog niet zo lang geleden, vrij recent eigenlijk. Die mevrouw was psychiatrisch bekend, dus het was al heel moeilijk om met haar om te gaan. En ze was vrij depressief van aard. En maar pushen en maar pushen om haar toch maar een beetje vooruit te krijgen, want ze kon lichamelijk heel veel, maar ze had er gewoon geen puf in. Ze was gescheiden, had een zoon waarmee ze een problematische relatie had. Ja, ze had eigenlijk niet meer echt iets om voor te vechten. En ja, ook altijd het bed omhoog pompen, zodat ze er niet in kon klimmen."

Verpleegkundigen rechtvaardigen dergelijke dwingende activiteiten veelal door te verwijzen naar hun professionele taak.

Verpleegkundige: "Je blijft ook aandringen bij patiënten omdat je weet dat het niet goed is. Je kunt dat ook voor jezelf, vanuit je verpleegkundige-zijn, ook niet maken. Je moet je daartegen verzetten, dat druist in tegen je professio. nele taak."

\section{Zich voegen naar vragen van patienten}

Soms voegen verpleegkundigen zich in dergelijke conflicterende situaties naar de mening van patiënten.

Verpleegkundige: "Maar ja, zoals bij ons, die mensen hebben geen weerstand en moeten zich iedere dag wassen. Dat probeer ik dan duidelijk te maken en meestal beseffen ze dat dan ook wel en gaan ze zich wassen. Maar ja, je moet echt niet tien keer aan die mensen gaan sjorren, van ja 'u moet en u zult'. Dat heeft helemaal geen zin."

Verpleegkundige: "Tja, en dan doe ik maar wat zij wil. Ik ben het daar niet mee eens. Dat heb ik ook gezegd. Maar ja, als zij dan persé haar sigaret wil roken, dan doet ze maar."

Soms doen verpleegkundigen wat patiënten van hen vragen, ook al zijn ze het daar niet mee eens. Ze verantwoorden dit door te verwijzen naar de eigen verantwoordelijkheid van patiënten.

Verpleegkundige: "En als ze zich niet willen wassen, dan wassen ze zich niet.

Die verantwoording hebben ze nog wel zelf." 


\section{Wel of niet meegaan met uragen van patiënten?}

In het denken en handelen van verpleegkundigen is een aantal overwegingen zichtbaar om zich al dan niet te voegen naar vragen van patiënten. Verpleegkundigen drukken soms hun eigen opvattingen over goede zorg erdoor ondanks alle tegenwerking van patiënten, omdat ze het gevoel hebben dat ze niet anders kunnen.

Verpleegkundige: "En achteraf, nu stond de advertentie in de krant en dan denk ik van 'och arme', eigenlijk zo. Maar hadden we haar dan moeten laten liggen? Was ze ook niet gelukkig geweest. Dat is heel moeilijk. Wat is nu de tussenweg? Je denkt dat mensen er iets mee winnen, daar doe je het voor. Anders deed je het niet."

Verpleegkundigen gaan ervan uit dat de dwang die zij op patiënten uitoefenen er uiteindelijk toe zal leiden dat het leven van patiënten op de langere termijn weer draaglijker wordt. Toegeven aan de vraag van een patiënt niet te willen eten, te drinken of uit bed te komen is voor verpleegkundigen haast onmogelijk. Daar kunnen ze gewoonweg niet aan voldoen, omdat ze ervan uitgaan dat voor patiënten uiteindelijk een draaglijk bestaan ook samenhangt met een gezond bestaan. Een andere overweging om al dan niet mee te gaan met vragen van patiënten, heeft te maken met de fysieke schade die een patiënt oploopt als gevolg van zijn eigen gedrag. Wanneer het gezonde fysieke bestaan wordt bedreigd, zijn verpleegkundigen geneigd vragen van patiënten die hun gezondheid schaden te negeren.

Verpleegkundige: "We hebben een mevrouw die ligt veel in bed. Ze zit nu in de stoel en ze komt uit bed, maar ze zegt altijd 'nee'. Je moet daar toch tegenin gaan en 'ja' zeggen, want als je toegeeft aan haar, dan ja, dan komt er nooit wat van, dan blijft ze dagen in bed liggen, dan komt ze nooit uit bed. Kan ook niet, dan krijgt ze van alles."

Wanneer het gaat om andere vragen dan vragen die samenhangen met 'een gezond fysiek bestaan', zijn verpleegkundigen veel terughoudender in het negeren van vragen van patiënten. Wanneer patiënten niet willen praten over hun emoties, dan dringen verpleegkundigen minder aan, ook al denken ze dat een gesprek de situatie voor patiënten draaglijker zal maken.

Verplergkundige: "Kijk, je hebt mensen die willen niet over hun gevoelens praten. met niemand niet. Dan probeer je hen wel aan de praat te krijgen. maar ja, je moet dat ook weer niet opdringen. Dan denk ik meestal 'tja, laat maar' en dan kijk ik of ik er later nog op terug kom."

Wanneer het gaat om andere vragen die niet samenhangen met fysieke gezondheid en lichamelijk letsel, is veel minder hard te maken wat er op het spel staat. Wanneer iemand niet eet of drinkt gaat hij of zij uiteindelijk dood. Van 'niet praten' zul je niet overlijden. Bovendien speelt ook het tijdsaspect een rol. Praten kan altijd nog, terwijl een decubituswond bij patiënten die in 
een slechte lichamelijk conditie verkeren niet lang op zich laat wachten. In het denken en handelen van verpleegkundigen is zichtbaar dat ze in situaties waarin patiënten zichzelf lichamelijk letsel toebrengen, sneller vragen van patiënten negeren dan in omstandigheden waarin het gaat om bijvoorbeeld de manier waarop patiënten met het ziek zijn, behandeld worden of opgenomen zijn omgaan of hoe hun contact met familie verloopt. In de afweging al dan niet in te gaan op vragen van patiënten speelt niet alleen het risico en de ernst van de fysieke schade een rol. Ook vragen verpleegkundigen zich af of patiënten inzicht hebben in hun eigen gedrag en of ze de consequenties kunnen overzien.

Verpleegkundige: "Als je alles uitlegt wat eventueel de gevolgen ervan kunnen zijn, dan moet hij het toch zelf weten. Hij is volwassen genoeg om zelf te weten hoe en wat. En als je hem alles duidelijk uitlegt, vind ik, en de gevaren die eruit voortvloeien uitlegt en hij houdt zich daar niet aan, dan is het zijn eigen pakkie an."

Belangrijk is volgens verpleegkundigen dat patiënten snappen waar het om gaat en begrijpen wat er op het spel staat. Als dat het geval is gaan verpleegkundigen mee met vragen van patiënten. Tot slot speelt voor verpleegkundigen mondigheid van patiënten een rol bij de afweging al dan niet mee te gaan met vragen van patiënten. Naar patiënten die verbaal sterk zijn voegen verpleegkundigen zich eerder, dan naar patiënten die hun wensen niet goed kunnen of willen uiten of formuleren.

Ik loop met Bea mee vandaag. We lopen eerst de kamer van Dirk binnen. Een man van 35 jaar. Bea trekt de gordijnen open en zegt 'zo, en nu onder de douche'. Dirk wordt wakker en sputtert tegen. Hij wil nog even blijven liggen. Hij vindt het vreselijk zo vroeg op te staan. Bea zegt dat dit niet anders kan. Als alle patiënten tot ro uur willen blijven liggen krijgen zij hun werk niet gedaan. Dirk zegt dat hij ook niet iedereen is, maar hij alleen. Hij kan toch nog even blijven liggen, terwij] Bea eerst andere patiënten verzorgt. Dat vindt Bea weer niet eerlijk, want dan kan hij uitslapen en anderen niet. 'Maar dan is morgen gewoon iemand anders aan de beurt' zegt Dirk. Daar heeft Bea niet van terug en ze zegt 'okay dan nog een half uurtje' en we gaan weer weg. Later op de ochtend lopen we bij mevrouw $\mathrm{x}$ naai binnen. Een oudere stille vrouw, die niet veel zegt en vraagt. Terwijl Bea de kamer binnenloopt en de gordijnen opentrekt zegt ze 'aan tafel ontbijten?'. Mevrouw $x$ zegt dat ze liever in bed ontbijt en daarna eruit komt. Bea zegt 'maar aan tafel eet je toch veel prettiger' en binnen twee minuten zit mevrouw $x$ aan tafel.

Verpleegkundigen voegen zich sneller naar vragen van patiënten die hun opvattingen goed kunnen verwoorden, dan naar patiënten die dat niet kunnen of niet doen. Patiënten moeten van zich laten horen, wanneer ze het niet eens zịn met de zorg die verpleegkundigen aan hen geven. 


\section{Blijven zoeken naar overeenstemming}

Wanneer verpleegkundige en patiënt in een conflict terecht komen, worden verantwoordelijkheden rigoreus verdeeld. In dergelijke situaties blijven verpleegkundigen toch steeds zoeken naar overeenstemming met patiënten. Dat was bijvoorbeeld het geval in de situatie die eerder is beschreven, waarin een verpleegkundige een patiënt ertoe verleidt haar haren eraf te scheren. De verpleegkundige in de situatieschets heeft al haar overredingskracht gebruikt om deze mevrouw ervan te overtuigen dat ze haar haren eraf moet scheren. Het is een heel proces geweest de patiënt zo ver te krijgen, waarbij de verpleegkundige in eerste instantie mee is gegaan met de patiënt, maar tegelijkertijd is blijven vasthouden aan haar eigen opvattingen. Veel praten, maar ook laten zien dat je met een sjaal iets leuks kan maken. Dat heeft na een tijdje geleid tot het afscheren van de haren. Wanneer een gezond bestaan in de toekomst het dreigt af te leggen ten opzichte van bijvoorbeeld het verminderen van lijden, omdat patiënten op een bepaald moment hieraan prioriteit geven, betekent dit niet dat verpleegkundigen zich daarbij neerleggen. Integendeel, in dergelijke situaties blijven ze zoeken naar overeenstemming met patiënten, waarin zowel een gezond bestaan als ook het verminderen van lijden hun deel hebben. Datzelfde geldt ook voor situaties waarin verpleegkundigen uiteindelijk bepalen wat er gebeurt. Ook dan proberen ze door met patiënten in gesprek te blijven, te zoeken naar overeenstemming.

Verpleegkundige: "En dan vroeg ik maar steeds 'snapt u waarom het toch beter voor $\mathrm{u}$ is om uit bed te komen?'."

\section{Gaat het om nu of om later?}

In het voorafgaande is besproken dat voor verpleegkundigen het tegemoet komen aan zorgbehoeften van patiënten niet altijd samenvalt met beantwoorden van hun vragen. Wanneer patiënten iets vragen dat volgens verpleegkundigen de situatie niet draaglijker zal maken, dan komen ze daar niet zonder meer aan tegemoet. Verschil van mening over wat goed is om te doen, heeft veelal te maken met een tijdsperspectief. Gaat het om het hier en nu of gaat het om later?

\section{Korte en lange termijn}

Verpleegkundigen maken een onderscheid tussen de korte en lange termijn. Tegemoet komen aan concrete vragen van patiënten in het hier en nu om hun situatie draaglijker te maken, betekent soms dat in de toekomst de situatie juist zal verslechteren. Wanneer patiënten niet eten, niet drinken of niet uit bed komen omdat ze zich beroerd en ellendig voelen, zal dat er op de langere termijn toe leiden dat hun situatie minder draaglijk wordt. Verpleegkundigen 
gaan er van uit dat patiënten hun situatie in het hier en nu zo pregnant als ondraaglijk kunnen ervaren dat het voor hen moeilijk is vooruit te kijken.

Tegemoet komen aan zorgbehoeften van patiënten is een proces, waarin gezocht wordt naar overeenstemming. Hierbij spelen zowel ervaringen, gevoelens en emoties van patiënten een rol, als opvattingen van verpleeg. kundigen over wat goed is om te doen. Gezamenlijk wordt gezocht naar een situatie waarin beide zich kunnen vinden. Hierbij wordt zowel de korte termijn als de lange termijn betrokken.

In deze paragraaf zijn morele ervaringen van verpleegkundigen bespro. ken, door situaties te bestuderen waarin verpleegkundigen het gevoel hebben dat de zorg die ze aan patiënten geven onder spanning staat. Soms vragen patiënten van verpleegkundigen iets anders dan wat verpleegkundigen denken dat goed voor hen is in het kader van een draaglijk bestaan. Tegemoet komen aan zorgbehoeften van patiënten betekent niet dat vragen en wensen van patiënten zonder meer worden beantwoord. In het denken en handelen van verpleegkundigen is wel zichtbaar dat, wanneer ze met patiënten van mening verschillen, er wordt gezocht naar overeenstemming. Dat doen ze bijvoorbeeld door wederzijds begrip te creëren, door patiënten te stimuleren, motiveren, overtuigen en over te halen tot bepaald gedrag of door een middenweg te bewandelen. Wanneer ze zoeken naar overeenstemming met patiënten, proberen ze conflicten te voorkomen waarin ze lijnrecht tegenover patiënten staan. Reden daarvoor is dat ze ervan uitgaan dat in dergelijke situaties de mogelijkheid tot zorgen wordt ondermijnd. Wanneer er geen open communicatie is tussen verpleegkundigen en patiënten zullen patiënten hun emoties, gevoelens en ervaringen niet laten zien, waardoor verpleegkundigen niet weten hoe ze de situatie voor hen dragelijker kunnen maken. Wanneer een situatie desalniettemin op een conflict uitloupt, treken verpleegkundigen de verantwoordelijkheid voor de inhoud van het zorgproces volledig naar zichzelf toe of geven deze aan de patiënt. Soms bepaalt de verpleegkundigen wat er gebeurt en soms kan de patiënt dat bepalen. In beide situaties blijft het handelen gericht op het vinden van overeenstemming, omdat volgens verpleegkundigen alleen een dergelijke situatie er uiteindelijk toe kan bijdragen dat de situatie voor de patiënt draaglijker wordt.

\section{ZORGVERLENING IN RELATIE TOT BEHANDELBELEID}

In dit hoofdstuk worden morele ervaringen van verpleegkundigen besproken door op zoek te gaan naar situaties waarin zij het gevoel hebben dat de zorg die zij aan patiënten geven onder spanning staat. Behandelbeleid dat artsen uitzetten heeft consequenties voor de zorg die verpleegkundigen al dan niet 
aan patiënten kunnen geven. In deze paragraaf komen eerst een aantal situaties aan de orde waarin verpleegkundigen belemmeringen in de zorg ervaren. Vervolgens wordt besproken hoe ze deze hanteren.

\section{Behandelbeleid belemmert goede zorg}

Allerlei afspraken die artsen maken in het kader van behandeling hebben effect op de zorg die verpleegkundigen aan patiënten geven. Sorns leidt dat tot situaties waarbij de zorg onder spanning komt te staan.

\section{Ondergraven van aandacht voor angst en onzekerheid}

Regelmatig doet zich de situatie voor dat een verpleegkundige informatie heeft over een patiënt, die de patiënt zelf nog niet heeft. Deze situaties komen voor omdat artsen bijvoorbeeld nog geen tijd hebben gehad een patiënt te informeren of omdat gewacht wordt op familie die pas op een later tijdstip bij een gesprek aanwezig kan zijn. Gevolg hiervan is dat gedurende een bepaalde periode verpleegkundigen al op de hoogte zijn van het feit dat de behandeling bijwoorbeeld niet heeft aangeslagen, maar dat een patiënt dat nog niet weet. Om verschillende redenen staat volgens verpleegkundigen een dergelijke situatie het draaglijk maken van de situatie voor patiënten in de weg. Wanneer verpleegkundigen niet kunnen praten met patiënten kunnen ze niet goed ingaan op hun angst en onzekerheid.

Verpleegkundige: "Voor patiënten is dat heel vervelend die onzekerheid.

Vooral als ze toch het gevoel hebben dat er iets aan de hand is. Je kunt er dan niets mee. terwijl je dat wel graag zou willen. Soms houden patiënten het niet van de spanning. Dat is heel vervelend. Daar kun je darn niets aan doen." In hoofdstuk 4 is besproken dat verpleegkundigen patiënten soms informatie onthouden, wanneer ze denken dat deze dat niet aankunnen. Patiënten die bijvoorbeeld door de diagnose zo in de war zijn dat ze niet kunnen luisteren of die zelfs in paniek raken van details van de behandeling en zorg. In dergelijke situaties onthouden verpleegkundigen patiënten informatie, omdat het volgens hen de draaglijkheid van de situatie niet bevordert. In een situatie waarin een patiënt juist bang en onzeker wordt door gebrek aan informatie, wordt de draaglijkheid van de situatie ondermijnd. Informeren van patiënten over ziekte en behandeling is voor verpleegkundigen van afdeling ro niet zo zeer iets waar patiënten recht op hebben, als wel iets dat ze soms wel en soms niet doen om de situatie voor een patiënt zo draaglijk mogelijk te maken. 


\section{Een aanslag op de vertrouwensband}

Een andere reden dat zorg onder druk kan komen in omstandigheden dat verpleegkundigen op de hoogte zijn van informatie die patiënten nog niet weten, is dat dit niet strookt met de vertrouwensband.

Verpleegkundige: "Dat is moeilijk hoor. Ja, als alle uitslagen binnen zijn en wij weten het en het gesprek wordt dan gepland met de partner, dan kun je het nog niet gelijk zeggen. Ja, dan moet je toch, als je dan naar de patiënt toegaat, als je dat dan weet, dan moet je toch 'gewoon' doen. En niet zo van 'och arme, hij zit helemaal vol kanker' en 'och', weet je wel. Dat heb je in je achterhoofd, maar dat mag je niet laten blijken. Je kan er dan niets mee. Je moet eigenlijk alleen maar hopen dat ze je niet te veel vragen. Sommige patiënten vragen dan ook niks, maar er zijn ook patiënten die wel vragen en dat komt toch heel vaak voor. En dat is dan toch heel lastig als je die mensen goed kent."

Zoals in de voorafgaande hoofdstukken is belicht, beschouwen verpleegkundigen een vertrouwensrelatie met een patiënt als een noodzakelijke voorwaarde voor zorg. Ze bouwen daarom met verschillende patiënten een dergelijke relatie op. Niet met patiënten kunnen praten over iets waar ze zich zorgen over maken, past niet bij een dergelijke relatie. Zorg wordt belemmerd, omdat de open en eerlijke communicatie die hoort bij een vertrouwensrelatie niet mogelijk is.

Verpleegkundige: "Bij patiënten die je niet zo goed kent is dat nog wel te doen.

Maar als je patiënten hebt, ja, waar heb je al niet over gepraat met hen en dan opeens kan dat niet meer. Voor je gevoel kan dat dan niet meer, want wat moet je dan zeggen? Je weet dat de behandeling niet heeft aangeslagen, waar praat je dan over?"

Zorg komt onder druk te staan als verpleegkundigen niet eerlijk kunnen zijn tegen patiënten wanneer ze met dergelijke patiënten een vertrouwensband hebben opgebouwd. Dergelijke situaties, waarin een verpleegkundige weet dat de behandeling bijvoorbeeld niet heeft aangeslagen maar de patiënt daar nog niet van op de hoogte is, kunnen soms wel een dag of langer duren. Verpleegkundigen moeten gedurende deze periode wel steeds in contact treden met patiënten. De zorg gaat gewoon door. Het eten moet worden gebracht, medicatie moet worden uitgedeeld. Gedurende deze zorg stellen patiënten vragen aan verpleegkundigen over uitslagen van behandeling, die door hen uiet kunnen worden beantwoord en waarover nauwelijks kan worden gepraat.

\section{Te rooskleurige informatie}

Niet alleen het tijdstip waarop artsen patiënten informeren kan de zorg die verpleegkundigen aan patiënten geven onder druk zetten. Dat kan ook gebeuren door de inhoud van dergelijke informatie. Verpleegkundigen ervaren belemmeringen in de zorg door de manier waarop artsen patiënten 
informeren over prognoses, bijwerkingen en/of complicaties van behandeling. Verpleegkundigen vinden dat artsen de situatie vaak rooskleuriger voorstellen dan ze is.

Verpleegkundige: "Ik vind dat een arts een behandeling zeer subjectief en optimistisch meedeelt. Dan hebben ze het steeds over die procenten die het halen en noemen ze niet die procenten die het niet halen. Vaak is het ook $50-50$, of nog minder, maar daar gaan ze dan snel overheen. En daar verder niets over zeggen. En dat vind ik toch vaak niet objectief meedelen van een behandeling. Dat geldt ook voor de complicaties en zo."

Volgens verpleegkundigen kunnen patiënten last krijgen van rooskleurige informatie, omdat ze extra ongerust raken wanneer het ziekteproces anders verloopt dan ze gedacht hadden.

Verpleegkundige: "En dan zeg ik ook altijd, zeg dat nou niet, want dan rekenen patiënten daarop. Maar ja, dat doen ze dan toch. Of ze zeggen dat al die complicaties, infecties en zo goed te behandelen zijn, maar alle pijn die patiënten daarvan hebben, dat vergeten ze dan."

Verpleegkundigen moeten er veel werk van maken in dergelijke omstandigheden de situatie voor patiënten beter verdraaglijk te maken, door patiënten gerust te stellen en voortdurend uitleg te geven.

Verpleegkundige: "En dan wordt het allemaal heel mooi voorgesteld en dan kiest de patiënt er voor en dan uiteindelijk beginnen de complicaties. En dan, ja, dan begint de ellende. Dan zitten wij er eigelijk mee. Omdat, de patiënt is het allemaal mooi voorgesteld, de patiënt is mooi ingelicht en dan valt het tegen." Door de wijze waarop artsen patiënten informeren over behandelingen, bijwerkingen, complicaties en/of prognoses wordt bij patiënten bepaalde verwachtingen gewekt. Wanneer deze verwachtingen niet uitkomen, kunnen patiënten ongerust worden. Patiënten kunnen achteraf ook spijt kriigen van hun toestemming voor de behandeling, wanneer ze vooraf geen duidelijk beeld hadden van wat hen te wachten stond. Er zijn patiënten die zeggen dat ze niet voor de behandeling gekozen zouden hebben, wanneer ze geweten hadden welke pijn en lijden daarmee samenhing.

Verpleegkundige: "Wat je ook tegenkomt bij patiënten en wat ze zelf ook zeg. gen 'de voorlichting is niet goed geweest'. Het is me allemaal rooskleuriger voorgesteld. Als ik dit had geweten, dan had ik dit nooit gedaan. Ja, dat zijn situaties die komen toch nog wel voor ja."

Artsen kunnen goede redenen hebben om patiënten op een bepaalde manier te informeren. Gevolg daarvan is echter wel dat patiënten ongerust kunnen worden, omdat het bij hen anders loopt dan ze verwacht hadden en ze kunnen zelfs spijt krijgen van hun keuze voor behandelen. 


\section{Zorgen wordt tot pijnigen}

Een andere situatie waarin zorg die verpleegkundigen geven onder spanning komt te staan is het gevolg van meningsverschillen met artsen over de vraag of doorbehandelen nog wel zin heeft. Gevolg daarvan kan zijn dat verpleeg. kundigen allerlei pijnlijke handelingen aan het lichaam van een patiënt moeten uitvoeren waar ze zelf niet meer de zin van inzien. Zorgen verwordt dan als het ware tot 'pijnigen'.

Op verschillende momenten stellen verpleegkundigen de vraag of doorbehandelen nog wel zin heeft. Bijvoorbeeld wanneer ze ervan uitgaan dat patiënten de behandeling niet zullen overleven.

Verpleegkundige: "Bovendien waren er nog allemaal behandelingsopties, zeiden ze. Daar geloofde de patiënt niet meer in. Wij ook niet."

Verpleegkundige: "Soms denk je 'nee, toch, dat gaan ze toch niet doen'. dan weet je eigenlijk op voorhand dat het niet gaat lukken."

Soms zien artsen nog allerlei behandelmogelijkheden, terwijl verpleegkundigen denken dat geen enkele behandeling een patiënt nog kan redden. Het gevoel dat behandelen geen zin meer heeft wordt nog versterkt wanneer patiënten ernstig pijn lijden.

Verpleegkundige: "En bij haar, wat me bij haar nog tegenstond, is dat ze zo'n pijn had. Verschrikkelijke pijn om iedere keer weer dat systeem open te houden en dan 'waarom?' he, dat vraag je je dan af."

Verpleegkundige: "Op een gegeven moment zagen wij als verpleegkundigen, we gingen mee met de patiënt die euthanasie had gevraagd. Wij zagen dat zij echt een lijden had. Terwijl de arts die vond dus dat zij niet ondraaglijk leed." Wanneer patiënten dan ook nog aangeven dat ze niet meer behandeld willen worden, denken verpleegkundigen echt dat artsen op de verkeerde weg zitten. Zoals in de situatie waarin een patiënt om euthanasie had gevraagd.

Verpleegkundige: "Die mevrouw had heel erg veel pijn en daar was niet goed iets aan te doen. Daarbij was deze mevrouw, was al zeer slechtziend, en had gehoopt door de transplantatie weer zicht te kunnen krijgen. Dat is niet gebeurd. Het zicht is achteruit gegaan. Ze is nog een keer naar buiten gegaan. Het sneeuwde en de zon scheen. Zij wilde kijken wat ze nog kon zien, en ze zag alleen maar zwart, en dat was zo'n enorme klap voor deze mevrouw. I $k$ dacht, ja inderdaad het leven valt deze mevrouw heel erg tegen. Hoe zij geleefd heeft, gewerkt heeft en in het leven heeft gestaan. lk kan me dat heel goed voorstellen."

Bij het bestuderen van de zorg die verpleegkundigen aan patiënten geven is zichtbaar dat voor verpleegkundigen regelmatig de grens aan behandelen eerder is bereikt dan voor artsen. 
Verpleegkundige: "Als mensen die voor deze patiënt zorgen ervaren we dat toch heel anders. Allemaal verhalen over 'zo kan dat niet langer, zo gaat dat niet langer, we weten ons geen raad meer."

Verpleegkundigen zien pijn en lijden van patiënten van dichtbij. Daardoor krijgt dit lijden voor hen een andere betekenis.

Verpleegkundige: "Artsen staan toch verder af van patiënten, dat is uiteinde-

lijk toch zo. Wij zien die mensen veel vaker en maken wat mee samen, dan

kijk je daar toch anders tegenaan."

Verpleegkundigen geven vaak zeer intensieve verzorging aan patiënten, als groep 24 uur per dag. Verpleegkundigen zien daardoor veel van hun pijn en lijden. De situatie waarin verpleegkundigen zich met patiënten bevinden kan volgens hen leiden tot een ander beeld van vragen en behoeften van patiënten. Wanneer verpleegkundigen ervan uitgaan dat behandeling niet meer tot genezing zal leiden, staat de zorg die zij willen geven onder druk. In plaats van patiënten fysieke troost te kunnen bieden, de nadruk te leggen op comfort of het organiseren van pijnbestrijding, moeten ze pijnlijke ingrepen aan het lichaam van een patiënt uitvoeren.

Verpleegkundige: "Deze mevrouw is fysiek enorm ziek geweest, met alle fysieke problemen, koorts, diarree, noem maar op. En op het laatste kreeg zij ook nog het probleem dat zij bloedde bij het urineren. Dat is een heel pijnlijk gebeuren voor die mevrouw geweest, met katheters en spoelsystemen à I uur. Dat was een enorme belasting. Iedere keer dat je spoot deed het steeds meer pijn. En op een gegeven moment had ik daar zo'n moeite mee om daar weer te gaan spoelen, omdat ik wist dat het zo'n pijn ging doen en ze ook eigenlijk niet meer wilde. Dan kwam je binnen en dan wilde je je eigenlijk het liefst onzichtbaar maken. Dan keken ze (de patiënte en haar man) je zo aan met die vragende ogen. En ik kon niets voor haar doen. En dan moest je ook nog eens die blaas spoelen. En dat deed haar verschrikkelijk veel pijn. Dat was heel moeilijk. Ze had euthanasie gevraagd. Ze wilde niet meer. En ik kon me dat heel goed voorstellen. Ik kon me goed voorstellen dat het leven voor haar geen zin meer had. Maar dan toch maar steeds die blaas spoelen. Verschrikkelijk was dat."

Verpleegkundigen verrichten voortdurend allerlei handelingen aan het lichaam van patiënten in opdracht van artsen. Soms zijn handelingen voor patiënten pijnlijk, zoals bijvoorbeeld het toedienen van injecties, wondverzorging, het inbrengen van een sonde, en dergelijke. Veelal hebben verpleegkundigen geen moeite deze uit te voeren, omdat ze daar de zin van inzien in het kader van het bevorderen van een gezond bestaan voor een patiënt. In hoofdstuk 4 is aan de orde gekomen dat verpleegkundigen proberen dergelijke handelingen uit te voeren op een manier die voor patiënten zo draaglijk mogelijk is. $\mathrm{Bij}$ het verrichten van pijnlijke ingrepen hebben verpleegkundigen niet het 
gevoel dat de zorg die ze geven onder druk komt te staan. Dat is echter wel het geval wanneer verpleegkundigen handelingen moeten verrichten die de situatie voor een patiënt extreem ondraaglijk maakt terwijl ze er de zin niet meer van inzien. Niet het verrichten van pijnlijke handelingen zelf bepaalt of zorg al dan niet goed is, maar de vraag of de handelingen zin hebben in het kader van het bevorderen van een gezond bestaan.

\section{Artsen verzetten zich tegen pijnverlichting}

Een laatste situatie waarin goede zorg volgens verpleegkundigen onder druk komt te staan door behandelbeleid van artsen, heeft te maken met het verlichten van fysiek lijden. Zoals in hoofdstuk 4 is belicht, is het handelen van verpleegkundigen gericht op het verminderen van fysieke pijn en lijden van patiënten. Sommige activiteiten kunnen ze zelf uitvoeren, zoals bijvoorbeeld het bieden van fysieke troost of comfort. Bij andere activiteiten zijn ze echter afhankelijk van artsen.

Verpleegkundige: "Een paar weken geleden, die mevrouw met die flinke ascitusbuik, waar we toen zes liter uitgehaald hebben in eerste instantie. Nou 24 uur later was ze dus weer volgelopen. Had een hele slecht nacht gehad en ze had 's morgens alleen maar tegen me gezegd 'het enige dat ik wil, is dat ze dit uit mijn buik halen'. Nou, dan komt dus een dokter, die weet eigenlijk van niets en $i k$ zeg 'ik denk wel dat jullie haar daar vandaag niet zo moeten laten liggen. Ik denk dat jullie moeten zorgen dat ze het toch wel wat comfortabeler heeft'. Zegt die arts 'dat heeft toch geen zin, we hebben het gisteren gedaan, en het kwam ook terug'. Ik zeg 'dat klopt, maar ik dacht dat het hier allemaal om een beetje kwaliteit ging'. Ik zeg 'hier moeten twee dingen gebeuren, die buik moet leeg en die pijn moet bestreden worden. Ik zeg, 'je hebt kans dat ze morgen dood is, maar dat is wat anders. Ze kan dood gaan met of zonder dikke buik en ik hoop maar dat ze dat zonder dikke buik doet'. Ik was toch kwaad, en 's middags had hij het dan toch gedaan. De dag daarna was ze dood. 's Morgens om zeven uur was ze dood. Maar goed, we hebben gedaan wat we konden. ${ }^{n}$

Verpleegkundigen kunnen zelf geen medische handelingen verrichten zoals het uitvoeren van een punctie. Dat moeten artsen doen. Verpleegkundigen voelen zich in de zorg belemmerd wanneer artsen zich verzetten tegen hun voorstellen om pijn bij patiënten te verlichten. Dat is ook het geval in bovenstaande situatie. De arts is van mening dat de punctie geen zin heeft omdat het vocht terug zal komen. Daar heeft hij gelijk in. Maar de verpleegkundige heeft in deze situatie een ander doel voor ogen. $\mathrm{Zij}$ wil de situatie voor deze mevrouw zo draaglijk mogelijk maken. Ze legt daarom de nadruk op het lijden van deze mevrouw. Zij wil comfort bieden, los van de vraag of de interventie zal bijdragen tot genezing of hoe lang het effect van de punctie zal aan- 
houden. Verpleegkundigen ervaren dat de zorg die zij willen geven aan patiënten om hun situatie zo draaglijk mogelijk te maken onder druk komt te staan, wanneer artsen daar niet aan meewerken.

In deze paragraaf zijn tot dusverre situaties beschreven waarin verpleegkundigen ervaren dat de zorg die ze willen geven onder spanning komt te staan door behandelbeleid van artsen. In het vervolg van deze paragraaf komt aan de orde hoe verpleegkundigen dergelijke spanningen hanteren.

\section{Ruimte creëren}

Door het behandelbeleid van artsen voelen verpleegkundigen zich soms beperkt in hun bewegingsvrijheid om zorg te geven die volgens hen het leven voor patiënten draaglijker maakt. Op verschillende manieren proberen verpleegkundigen in dergelijke omstandigheden ruimte te creëren voor hun opvattingen van wat goed is om te doen.

\section{In gesprek met artsen}

Verpleegkundigen proberen ruimte te creëren door hier met artsen over te praten. Ze stellen bijvoorbeeld een vraag met als doel de arts in een bepaalde richting te sturen.

Verplergkundige: "Soms pakken artsen dat ook wel op. Dan heb je een idee en

dan vraag je dat aan artsen en soms gaan ze daar ook wel in met.'

Een andere manier om ruimte te creëren voor hun opvatting van goede zorg is door artsen te overtuigen met kennis.

Verpleegkundige: "Wat je hier nodig hebt is kennis. Niet alleen om te observe-

ren, maar ook om artsen soms in de goede richting te krijgen."

Verpleegkundigen gebruiken medisch-technische kennis van ziektebeelden, behandelingen, complicaties, bijwerkingen of werking van medicijnen om artsen van hun mening over wat goed is om te doen te overtuigen.

Verpleegkundige: Bijvoorbeeld, die mevrouw op kamer $\mathrm{x}$, morfine gekregen, heeft niets geholpen. Ze heeft gebeld. Mocht ze nog eens $5 \mathrm{mg}$ intramusculair hebben. Nou als dat na een kwartier niet werkt dan werkt dat niet. En de arts gaat dus niet naar haar toe. Dus ik zeg van 'golh, je bent bij mevrouw $x$ gewenst'. Hij zegt 'waarom'. Ik zeg 'nou dic mevrouw ligt daar te huilen van de pijn en ik denk dat dat niet nodig is in deze situatie. Zegt hij 'jid, maar ze heeft al wat gehad'. Ik zeg 'dat is al meer dan een kwartier geleden en ik denk dat het wel eens tijd wordt om even naar deze patiënt toe te gaan."

Doordat de verpleegkundige kennis heeft van de werking van morfine, kan ze er tijdig bij de arts op aandringen dat hij actie onderneemt om de pijn van deze mevrouw te verlichten. Verminderen van fysieke pijn en lijden om de situatie voor patiënten draaglijker te maken speelt een belangrijke rol in het 
denken en handelen van verpleegkundigen. Deze verpleegkundige probeert de arts met kennis van medicatie te overtuigen en dit streven te ondersteunen. Ervaren verpleegkundigen hebben vaak veel medisch-technische kennis. Soms meer nog dan artsen, vooral wanneer deze nog niet lang op de afdeling zijn. Een andere activiteit die verpleegkundigen verrichten om in relatie tot artsen ruimte te creëren voor hun opvatting van goede zorg is door wederzijds begrip te creëren. Aan de ene kant proberen ze begrip te krijgen voor opvattingen van artsen. Aan de andere kant trachten verpleegkundigen bij artsen begrip te krijgen voor hun eigen ideeën.

Verpleegkundige: "Ja, vaak met beleidskwesties of met afspraken die gemaakt zijn, dat gaat niet altijd soepeltjes. Dan heb ik als verpleegkundige ook een eigen mening. Soms ben ik het daar gewoon niet mee eens. En dan stap je naar de arts en zeg je 'waarom is dat?'. Of als iets afgesproken wordt en ik niet tevreden ben met de uitleg, dan zal ik het hem duidelijk maken waarom ik het er niet mee eens ben. Ik wil wel hebben dat je me fatsoenlijk uitlegt waarom je zoiets afspreekt, als arts zijnde, dus de medische redenen wil ik weten. En ik zal dan duidelijk maken waarom ik vind dat dat niet zo is." Verpleegkundigen proberen een situatie te creëren waarin duidelijkheid is over overwegingen die artsen maken aan de ene kant en over hun eigen opvattingen aan de andere kant. Op verschillende manieren proberen verpleeg. kundigen in hun contact met artsen ruimte te creëren voor hun eigen opvattingen van goede zorg. Sommige verpleegkundigen krijgen daarbij meer ruimte van artsen dan andere. Verpleegkundigen moeten als het ware hun sporen verdiend hebben om door artsen gehoord en serieus genomen te worden. Verpleegkundigen die hun sporen verdiend hebben, worden dan naar voren geschoven om meningsverschillen te bespreken.

Verpleegkundige: "Ik werk nu al wat langer hier en ik merk dat artsen meer met me beginnen te praten. Eerst was het zo, dat ook al was het mijn patiènt, dan gingen ze gewoon naar Renee of Ineke wanneer ze iets wilden bespreken. Niet met mij. Artsen praten eigenlijk pas met je als ze in de gaten krijgen dat je veel weet, over ziekte en behandeling en zo, dan pas willen ze met je overleggen."

Verpleegkundige: "En dan denk ik, laat Ineke dat maar doen, naar haar luisteren ze eerder dan naar mij."

Artsen gaan vooral in gesprek met verpleegkundigen die al geruime tijd op de afdeling werken en veel kennis en ervaring hebben in de zorg voor deze patiëntencategorie. Jong gediplomeerden en leerlingen krijgen van artsen minder ruimte wanneer gesproken wordt over behandelbeleid. Door verpleegkundigen wordt daar gebruik van gemaakt, wanneer ze meningsverschillen met artsen willen bespreken. 


\section{Ruimte gebrek}

Verpleegkundigen vinden de ruimte die zij innemen om hun opvattingen van goede zorg te ventileren in direct contact met artsen soms te beperkt is. Ze hebben het gevoel dat artsen hun mening niet altijd op prijs stellen.

Verpleegkundige: "En soms dan denk ik 'en waarom vragen jullie dat niet aan ons?' Ze doen toch wat ze willen. Dan hebben wij zoiets van 'waarom doen jullie dat? Waarom gaan jullie door met behandelen?'. Dan denk ik 'wij weten daar ook wel jets van af. Je hebt ondertussen al zo veel mensen meegemaakt. Je ziet vaak meteen dat iemand een behandeling aan kan of niet. Maar ja, daar worden wij niet naar gevraagd."

Volgens verpleegkundigen zouden zij meer inbreng kunnen hebben in de behandeling die patiënten krijgen. Vooral verpleegkundigen die veel ervaringen hebben, gaan ervan uit dat zij inzicht hebben in complicaties en effecten van behandeling. Soms nemen verpleegkundigen die ruimte zelf om hun mening naar voren te brengen.

Verpleegkundige: "Ik denk dat wij voor de patiënt opkomen. Aan artsen toch altijd weer laten zien, dat daar een mens in bed ligt. Dat zijn niet alleen maar ja, getalletjes in een computer of beenmerg op zo'n plaatje. Dat gaat toch om het geheel wat daar in bed ligt of wat daar rond loopt. Ik denk dat je toch altijd een totaalbeeld blijft houden en ik weet niet of zij dat af en toe loslaten."

Verpleegkundige: "Als ik met een serieuze vraag van een patiënt naar een arts toe ga, dan wil ik dat er geluisterd wordt. En als dat niet gebeurt, sta ik een uur later weer voor de deur. Ik heb zoiets, het is niet voor mij. het is voor mijin patiënt. Het is voor mijn patiënt waar het om gaat. Daarom ga ik ervoor. Het is niet voor mij."

Hoewel verpleegkundigen zich regelmatig sterk maken in het belang van de patiënt, wil dat niet zeggen dat ze altijd de confrontatie met artsen aangaan wanneer ze denken dat deze iets doen wat niet bijdraagt aan de draaglijkheid van de situatie voor patiënten. Soms doen ze dat namelijk ook niet.

Ik zit met twee verpleegkundigen in de zusterspost. Ze praten met elkaar over het slechtnieuwsgesprek dat met $\mathrm{x}$ gepland is. Artsen willen dit gesprek zo snel mogelijk voeren, zodat ze met een nieuwe behandeling kunnen beginnen. Ze willen niet wachten. Verpleegkundigen vinden dat artsen moeten wachten tot familie er is. Vanavond komt zijn vriendin. Ze vinden dat die erbij moet zijn. Die paar uur kan er niet toe doen. Dan komt de arts binnen. Ik wacht verwachtingsvol af wat er gaat komen. Helemaal niets. Niemand zegt wat. De patiënt krijgt zijn gesprek zonder vriendin erbij. Soms nemen verpleegkundige de ruimte niet om hun opvattingen van goede zorg naar voren te brengen. Volgens de verpleegkundigen bepaalt de cultuur van de afdeling mede hoe zorgverleners met elkaar omgaan. 
Verpleegkundige: "Ik zie wel dat er steeds meer ruimte komt. In vergelijking met vroeger wordt er nu meer naar ons geluisterd. Maar toch, dat kan beter.

Sommige artsen staan daar ook meer open voor dan andere."

Verpleegkundigen gaan ervan uit dat artsen toch hun eigen weg gaan en dat: hun inbreng niet wordt gehoord.

Verpleegkundige: "Tja, zo is dat hier, zo gaan wij met elkaar om."

Verpleegkundige: 'Heb je dat aan dokter x gezegd waar je aan denkt?', zegt

Ineke tegen Theo. 'och, denk je dat dit zin heeft' antwoordt hij."

In direct contact met artsen vinden verpleegkundigen dat de ruimte om hun opvattingen over goede zorg naar voren te brengen soms te beperkt is. In het nu volgende wordt besproken dat verpleegkundigen verschillende activiteiten verrichten om ruimte te creëren voor hun opvattingen over goede zorg, die erop gericht zị̣n de situatie voor patiënten zo draaglijk mogelijk te maken.

\section{Ruimte creêren via patiênten}

Verpleegkundigen praten veel met patiënten over behandelingen en onderzoeken die ze krijgen. Patiënten stellen daar veel vragen over aan verpleegkundigen. Verpleegkundigen bereiden patiënten voor op de artsenvisite, zodat de patiënt op het moment dat de arts aan het bed staat de goede vragen kan stellen. Verpleegkundigen steunen patiënten op die manier in hun contact met artsen om hun zeggenschap over de behandeling te vergroten. Tegelijkertijd doet zich daarin de mogelijkheid voor op een indirecte manier het handelen van artsen te beinvloeden. Soms sturen verpleegkundigen patienten in een bepaalde richting met als doel het beleid van artsen te beinvloeden.

Verpleegkundige: "Wat wij doen is met patiënten vaak een briefje maken. Dan zeg ik 'schrijf uw vragen op, bedenk wat u wil weten'. Wij helpen daar dan vaak bij. Dan vraag ik 'hebt u hier of daar aan gedacht?'. Je kunt patiënten ook helpen, sturen ook, in de richting waarvan jij denkt daar moeten ze toch nog maar eens met de arts over praten. Laatst bijvoorbeeld, toen artsen dat onderzoek wilden afspreken, toen dacht ik 'moet dat wel?'. Mevrouw heeft dat toen zelf gevraagd bij de visite."

Een andere manier om ruimte te creèren voor hun eigen opvattingen van goede zorg via patiënten, is door informatie die artsen geven te relativeren. Wanneer verpleegkundigen het niet eens zijn met de informatie over behandeling of prognoses die artsen aan patiënten geven, gaan ze daar op het moment zelf niet $o p$ in. Ze vinden die informatieverschaffing de taak van artsen. Bovendien willen ze het vertrouwen dat patiënten in artsen hebben niet verstoren. Daarom relativeren ze deze informatie.

Verpleegkundige: "Dan zeg ik ook wel eens, nou ik ken ook wel mensen die er echt langer over gedaan hebben en dat er ook mensen zijn die het niet halen. Dat kan ook. Of toch dat je zegt dat de kans op infecties bijvoorbeeld wel reëel is." 


\section{Ruimte nemen}

Soms nemen verpleegkundigen de ruimte om hun opvattingen van goede zorg erdoor te drukken door hun eigen weg te gaan. Verpleegkundigen negeren soms opdrachten van artsen wanneer zij ervan uitgaan dat deze iets voorstellen dat de draaglijkheid van de situatie van patiënten ondermijnt. Zoals in de situatie waarin een verpleegkundige de opdracht krijgt om bloed te prikken.

Verpleegkundige: "Ik blijf niet bezig met prikken. Als een patiënt al d́rie dagen

geen temp meer heeft, dan vind $i \mathrm{k}$ het welletjes geweest. Dan prik ik niet." Het handelen van verpleegkundigen is erop gericht de situatie voor patiënten zo draaglijk mogelijk te maken. Hierbij laten ze zich niet alleen leiden door ervaringen van patiënten, maar ook door abstracte kennis die ze hebben van ziektebeelden en behandeling. Wanneer deze patiënt $40^{\circ} \mathrm{C}$ koorts had gehad of wanneer nog niet drie dagen was gekweekt, dan had deze verpleegkundige wel bloed geprikt uit de arm, ondanks het feit dat de patiënt daar veel last van zou hebben. Abstracte kennis van ziektebeelden en behandelingen worden ingezet om de situatie voor patiënten zo draaglijk mogelijk te maken. Deze kennis bepaalt hoever verpleegkundigen daarin kunnen gaan. Deze kennis bepaalt als het ware de grens van hun handelen gericht op het bevorderen van de draaglijkheid van het bestaan van patiënten.

\section{Conflicten hanteren}

In het voorgaande is besproken dat verpleegkundigen proberen ruimte te creëren voor hun opvattingen over goede zorg om het leven voor patiënten draaglijker te maken. Dat doen ze rechtstreeks in gesprek met artsen, meer indirect via patiënten of door hun eigen weg te gaan. Dat zijn tegelijkertijd manieren om conflicten met artsen te voorkomen. Wanneer meningsverschillen blijven bestaan. leggen verpleegkundigen zich meestal neer bị opvattingen van artsen.

Verpleegkundige: "Zij zijn eindverantwoordelijk, dat is nu eenmaal zo. Daar

moeten wij ons dan toch bij neerleggen. Niet meteen natuurlijk, maar toch."

Dat doen ze niet wanneer ze er vanuit gaan dat patiënten zich in een extreem ondraaglijke situatie bevinden. In dergelijke omstandigheden leggen verpleegkundigen zich niet neer bij het behandelbeleid van artsen en laten ze de situatie escaleren tot een conflict escaleren waarin verschillende partijen lijnrecht tegenover elkaar komen te staan. Dat was op afdeling ro bijvoorbeeld het geval in de reeds eerder genoemde situatie waarin een patiënt om euthanasie had gevraagd. Verpleegkundigen gingen er vanuit dat de patiënt. uitbehandeld was. Bovendien leed ze extreem veel pijn. Deze pijn werd. vooral veroorzaakt door pijnlijke ingrepen die verpleegkundigen aan haar 
lichaam uitvoerden. Bovendien zag de patiënt zelf de zin van de behandeling niet meer in. Deze situatie is uiteindelijk geëscaleerd.

Verpleegkundige: "Want op een gegeven moment was het alleen nog maar een welles nietes spelletje. Eén arts en horden verpleegkundigen die er voor waren en een hele kluit met artsen die er absoluut niet aan wilden. Het werd dus een confrontatie en we hadden het nooit tot een confrontatie moeten laten komen. En daar heb ik een aandeel in gehad in die confrontatie, door die enorme, hoe moet ik het zeggen, zoiets van 'we zullen wel eens zien wie hier voor een patiënt opkomt'. Er zat een enorme geldingsdrang op dat moment bij het hele team. Allemaal verhalen over: 'we kunnen het niet meer aan, het gaat zo niet langer, we weten ons geen raad meer'. Zoveel vragen, het was zo actueel, het was zo hoog opgelopen, gespannen en iedereen zag je op z'n tenen lopen."

In deze situatie werden verpleegkundigen dagelijks op extreme wijze geconfronteerd met pijn en lijden van een patiënt, die bovendien om euthanasie had gevraagd. In deze situatie zijn de verpleegkundigen met de artsen in conflict gegaan. Hoewel de situatie hoog opgelopen was, gingen verpleegkundigen en artsen pas in een heel laat stadium om de tafel zitten om elkaars standpunten te bespreken.

Verpleegkundige: "De communicatie is heel scheef geweest. Artsen hebben geen uitleg gegeven over hun beleid. De verpleging heeft echt gedacht van 'die artsen doen niets, ze laten die mevrouw hier liggen en wij zijn hier 24 uur per dag mee bezig en zij komen een kwartiertje en ze hebben het dan wel gezien en ze gaan weer naar huis'. Terwijl de artsen hebben alles uit de kast gehaald, maar die mevrouw was niet van haar pijn af te helpen. En de verpleging dacht 'de artsen doen niets', want ze hebben daar niets over uitgelegd. Terwijl achteraf, toen we wel gepraat hebben, toen was het idee: beide partijen hebben gelijk. Ik kon begrijpen waarom artsen niet met de euthanasievraag van deze patiënt konden meegaan. Zij zagen nog allerlei mogelijkheden voor deze mevrouw en iemand die blind is. dat is geen reden voor euthanasie. Maar van de andere kant was er ook begrip voor het standpunt van verpleegkundigen. Echt, een schreeuwende patiënt, een jonge vrouw ook nog. Ik bedoel, dat is ook verschrikkelijk. Dat gaat je door merg en been. En als je daar verder vanaf staat, is dat een stuk gemakkelijker. Het is dan logisch dat de arts daar anders over denkt."

Soms leiden spanningen tot conflicten, zoals in de genoemde situatie. Vooral omdat artsen en verpleegkundigen niet met elkaar hebben gesproken en hun standpunten niet hebben verduidelijkt, is het volgens verpleegkundigen op een conflict uitgelopen.

Hoewel verpleegkundigen en artsen regelmatig met elkaar praten over zorg en behandeling, is er weinig ruimte voor reflectie. Er wordt met name 
informatie uitgewisseld. Spanningen zoals in het eerste deel van deze paragraaf zijn beschreven, zijn nauwelijks onderwerp van gesprek tussen artsen en verpleegkundigen. Pas als er uiteindelijk sprake is van een conflict waarin partijen lijnrecht tegenover elkaar staan wordt er gepraat. Doordat spanningen tussen verpleegkundigen en artsen niet constructief worden aangepakt zijn er alleen maar verliezers, omdat niemand uiteindelijk tevreden is over de gang van zaken. Vooral patiënten lijden daaronder.

Verpleegkundige: "Maar die patiënt die lag er ondertussen! Ondertussen smeekte zij 'alsjeblieft help me uit mijn lijden, ik kies daarvoor, ik heb een euthanasieverklaring, mijn man staat er achter'. Er is ook nog een psychiater bij gehaald en die vond dus haar vraag ook heel reëel. Ik vind het jammer dat we het hebben laten uitlopen tot een conflict, waarbij de patiënt, die kwam op een gegeven moment op het laatste plan daardoor. Zij lag daar met al haar pijn, haar vragen, help me, help me, doe iets met me, help me. Al die onderliggende vragen bij deze mevrouw, die had je moeten uitspitten. En ik heb niet gezegd 'en nu gaan we om de tafel zitten en dan kijken we hoe we deze mevrouw zo goed mogelijk kunnen helpen'. En niet die euthanasievraag centraal stellen, dat is haar vraag wel, en die blijft er wel staan, maar we hadden het over een andere boeg moeten gooien. We hadden samen, artsen en verpleegkundigen, terug gemoeten naar de patiënt. De patiënt heeft dit en dit en dat. Dat is een probleem van de patiënt. Wat gaan we daaraan doen. Niet die euthanasievraag centraal stellen. Dat was natuurlijk wel een heel belangrijk onderwerp, dat heeft zich zo geuit bij deze mevrouw, maar daar achter kwamen nog een heleboel andere dingen. Nu hebben we haar eigenlijk ook nog in de steek gelaten."

Doordat een meningsverschil tussen artsen en verpleegkundigen over wat goed is om te doen voor een patiënt niet constructief is aangepakt, is de zorg gestagneerd. In het denken en handelen van verpleegkundigen is zichtbaar dat het proces van hanteren van spanningen in het belang is van de kwaliteit van zorg voor patiënten. Wanneer zorgverleners onderling niet in staat zijn deze spanningen adequaat te hanteren, staat de zorg voor patiënten onder druk. Het draaglijk maken van de situatie van patiënten heeft niet alleen van doen met de directe relatie tussen verpleegkundige en patiënt, maar heeft ook te maken communicatie en reflectie tussen zorgverleners onderling.

In deze paragraaf is gekeken naar spanningen die zich voor verpleegkundigen voordoen in relatie tot artsen. Hierdoor kon inzichtelijk worden gemaakt dat de bewegingsvrijheid die verpleegkundigen ervaren om goede zorg te geven, mede bepaald wordt door het behandelbeleid van artsen. Het proces van tegemoet komen aan zorgbehoeften van patiënten die samenhangen met het draaglijk maken van de situatie, speelt zich niet alleen af binnen de directe relatic tussen verpleegkundige en patiënt, maar krijgt mede vorm doordat 
ook artsen daarbij betrokken zijn. Om goede zorg te kunnen geven moeten verpleegkundigen niet alleen activiteiten verrichten die gericht zijn op zorgbehoeften van patiënten, maar moeten ze ook allerlei activiteiten verrichten die ruimte creëren om dat te doen.

De manier waarop verpleegkundigen spanningen in relatie tot artsen hanteren verschilt van de manier waarop spanningen in relatie tot patiënten worden gehanteerd. Hoewel verpleegkundigen ook in direct contact met artsen hun mening bespreken, proberen ze ook indirect - via de patiënt of door hun eigen gang te gaan - het behandelbeleid van artsen te sturen of te omzeilen om de situatie voor patiënten draaglijker te maken. Door dergelijke activiteiten trachten verpleegkundigen conflicten met artsen te voorkomen. Wanneer verpleegkundigen ervan uitgaan dat de situatie voor een patiënt extreem ondraaglijk is, dan laten ze het op een conflict uitlopen. Omdat momenten van communicatie en reflectie tussen zorgverleners onderling ontbreken, worden dergelijk conflicten, die zich alleen in uitzonderlijke situaties voordoen, veelal niet adequaat gehanteerd en stagneert de zorg voor patiënten.

\section{ZORG VOOR JEZELF}

In deze paragraaf worden morele ervaringen van verpleegkundigen besproken door de spanningen te analyseren die in verpleegkundigen zelf zijn gelokaliseerd. Deze spanningen hebben van doen met het feit dat verpleegkundigen als mens betrokken zijn bij de zorg die ze geven. In deze paragraaf komt aan de orde dat zorg voor patiënten onder druk kan komen, omdat verpleegkundigen ook voor zichzelf moeten zorgen.

\section{Betrokkenheid is begrensd}

In hoofdstuk 4 is beschreven dat verpleegkundigen ervan uitgaan dat persoonlijke betrokkenheid nodig is om te zorgen. Patiënten hebben daar volgens verpleegkundigen behoefte aan, omdat ze met een type problemen worden geconfronteerd dat daarom vraagt. Bijvoorbeeld met patiënten praten over hun emotionele pijn en lijden, omdat ze een levensbedreigende ziekte hebben, kan niet zonder als persoon betrokken te raken. Een compagnon zijn gedurende de behandeling, iemand die meedenkt en meeleeft, vraagt van verpleegkundigen dat ze als mens betrokken raken bij de zorg die ze geven. Bovendien - zo is in het vorige hoofdstuk besproken - is deze relationele betrokkenheid nodig om begrip te krijgen voor de specifieke situatie en persoon van een patiënt. 
Verpleegkundigen van afdeling ro hebben veelal expliciet gekozen voor deze patiëntencategorie, juist omdat ze begeleiden van patiënten een bevredigende en zinvolle ervaring vinden. Ze zijn er als het ware op gericht betrokken te raken bij patiënten.

Verpleegkundige: "Daarom heb ik ook eigenlijk voor deze afdeling gekozen, voor oncologische patiënten. Daar heb je toch een aparte band mee. Ik vind. als je nou op chirurgie werkt, dan zijn de mensen korter opgenomen en dan heb je daar toch niet zo de band miee, die je bij ons met patiënten hebt. Deze patiënten komen vaker terug en daardoor heb je er vaak een enorme band mee. Ook gewoon, je weet eigenlijk alles van die mensen. En dat vind ik dus wel, je bouwt een bepaalde relatie met die mensen op, en dat vind ik dus wel het leuke."

Bij het bestuderen van de zorg die verpleegkundigen aan patiënten geven is zichtbaar dat er een grens is aan menselijke betrokkenheid.

Verpleegkundige: "Het werk is geestelijk heel zwaar. Je bent zo intensief met deze mensen bezig. Deze mensen, de onzekerheden, kom ik hier doorheen, is het goed te behandelen? Je kunt mensen verliezen met een infectie, dat moet je niet bagatelliseren. Dat maakt het gewoon psychisch zwaar allemaal. Je bent daar toch mee bezig. En met deze mensen, gewoon, je probeert hen er toch doorheen te halen."

Verpleegkundigen van afdeling Io geven aan dat ze betrokken raken bij patienten. Tegelijkertijd vragen ze zich af hoe ver deze betrokkenheid mag gaan. Deze vraag wordt gesteld in het belang van patiënten.

Verpleegkundige: "Dat je meeleeft met patiënten, daar moet die patiënt ook iets aan hebben. Je kunt wel gezellig meehuilen met iemand, maar wat heeft die persoon daar dan aan. Je moet altijd in de gaten houden dat het niet om jou gaat, maar om de patiënt."

Verpleegkundigen gaan ervan uit dat het belangrijk is dat de gevoelens en emoties van verpleegkundigen niet voorop staan in de zorg. Wanneer betrokkenheid ertoe leidt dat ze hun eigen verdriet, angst of onzekerheid voorop stellen, wordt een grens overschreden. In die zin mag er, ondanks het belang van betrokkenheid, geen sprake zijn van een vriendschapsrelatie waarin deze wederkerigheid juist wel gewenst is.

Verpleegkundigen noemen verschillende risico's van betrokkenheid voor henzelf. Te grote betrokkenheid kan er bijvoorbeeld toe leiden dat ze zich kunnen verliezen in pijn en lijden van patiënten. Dat kan tot gevolg hebben dat een situatie voor hen zelf onverdraaglijk wordt.

Verpleegkundige: "Soms, dan denk ik 'och arme, waarom moet dit allemaal'. Weet je, het doet je soms gewoon pijn om te zien hoe moeilijk mensen het hebben. Maar dat moet je dan toch weer kunnen loslaten. Het helpt niemand als je voortdurend verschrikkelijk verdrietig wordt van alles wat er met men- 
sen hier gebeurt. Dat wil niet zeggen dat je niet moet meeleven, maar je moet dan toch ook kumnen loslaten. Je mag best wel eens verdrietig zijn, maar niet de hele tijd. Snap je?."

Hoewel verpleegkundigen vinden dat ze met patiënten moeten meeleven en af en toe best verdrietig mogen zijn, mag dat niet betekenen dat dit gaat overheersen. Een ander risico van betrokkenheid bij patiënten van afdeling Io is volgens verpleegkundigen dat dit ertoe kan leiden dat ze de situatie van patiënten te veel op zichzelf betrekken. Dat kan volgens verpleegkundigen bijvoorbeeld gemakkelijk gebeuren wanneer je zorgt voor mensen van je eigen leeftijd.

Verpletgkundige: "Vooral als je zorgt voor mensen van je eigen leeftijd, en dat komt nog al eens voor hier bij ons op de afdeling, dan vind ik dat zwaar. Dat is ook heel leuk natuurlijk, want ja, je voelt je toch meer betrokken bij mensen van je eigen leeftijd. Maar ik bedoel, je had het zelf kunnen zijn. Zoals die twee meiden, je kent ze wel, mijn leeftijd, allebei dood gegaan. Ja, dan vind ik het toch wel zwaar soms."

In dergelijke situaties is de betrokkenheid groot, omdat er vaak raakvlakken zijn en omdat het opbouwen van een band met elkaar gemakkelijker is. Deze zorg voor leeftijdgenoten brengt ook het gevaar met zich dat verpleegkundigen zich met hen gaan identificeren.

\section{Zoeken naar een evenwicht}

Zorgen voor patiënten vraagt van verpleegkundigen dat ze ook voor zichzelf zorgen. In het kader van de zorgverlening gaat het ook altijd om de vraag hoe zorg voor de ander zich verhoudt tot zorg voor jezelf.

Verpleegkundige: “Je hebt soms avonden dat je denkt 'en nu even niet'. Er is een periode geweest dat heel veel mensen heel veel rotte dingen hadden. En dat je dan soms denkt 'en nu wil ik gewoon even helemaal niet' Ja en achteraf denk ik dan 'is dat wel eerlijk tegenover de patiënten. Dan heeft iemand net dat woordje nodig of dat gesprek, en dan sjees jij er eigelijk maar langs. Maar ik kan niet altijd. Maar dat vind ik toch enorm, ja dat vind ik eigenlijk heel erg."

Wanneer verpleegkundigen aan zichzelf denken, vinden ze het toch vervelend dat ze daardoor patiënten te kort doen. Ze ervaren het als problematisch als ze niet die zorg aan een patiënt kunnen geven die deze op een bepaald moment van hen vraagt. Tegelijkertijd hebben ze het gevoel dat dit niet anders kan, omdat ze het anders zelf niet volhouden. Dergelijke ervaringen zullen zich voor verpleegkundigen op verschillende momenten voordoen. Voor pas gediplomeerde verpleegkundigen is bijvoorbeeld ieder gesprek waarin met patiënten wordt gepraat over emoties al snel intensief. Voor verpleegkundigen die al langer op de afdeling werken is het veelal de hoeveelheid 
intensieve gesprekken en de ernst van de situatie waarin patiënten verkeren, die op de langere termijn als belastend wordt ervaren.

Op verschillende manieren proberen verpleegkundigen te zoeken naar het goede evenwicht tussen zorg voor de ander en zorg voor zichzelf. Bijvoorbeeld door altijd alert te blijven op dit evenwicht en voortdurend de eigen grenzen te bewaken.

Verpleegkundige: "Goede zorg houdt ook in dat je grenzen moet stellen voor jezelf. Dat je ook daar zelf niet helemaal aan kapot gaat, dat moet je denk ik wel steeds bewaken. Dat dat ook bij diezelfde goede zorg hoort, dat je dat voor jezelf moet kunnen volhouden. Anders dan loop je zelf denk ik tegen een muur op, als je dat niet kunt."

Een graadmeter om te bepalen of het evenwicht uit balans is en betrokkenheid ten koste gaat van henzelf, is als hun privé leven er onder leidt.

Verpleegkundige: "Niet dat je thuis niet eens over patiënten mag praten of denken of dat je denkt van 'potverdorie moet dit of dat nu'. Maar het moet niet zo zijn dat je thuis alsmaar verdrietig bent, omdat het slecht gat met een patiënt. Dat kan niet. Tenslotte gaat het om patiënten en niet om je moeder of vader of weet ik wie. Je mag best meeleven met iemand, maar ja, niet ten koste van jezelf. Dat niet."

Een andere manier om het evenwicht tussen zorg voor jezelf en zorg voor de ander te bewaken, is door voor elkaar te zorgen. Situaties waarin verpleegkundigen sterk betrokken raken bij bepaalde patiënten worden door andere verpleegkundigen vaak nauw in de gaten gehouden.

Verpleegkundige: " $\mathrm{Jk}$ vond dus dat hij daar veel te ver in ging. Dat moet je niet doen. Dan hou je de zorg niet vol."

Verpleegkundigen letten ook op elkaar. Want juist als je erg betrokken raakt. bij patiënten, is het moeilijk te zien wanneer een grens overschreden is.

Verpleegkundige: "Het is natuurlijk wel zo, dat als je er middenin zit, dan kom je er ook niet zo goed van los. Zoals bij $x$, daar ben ik toch erg ver in meegegaan. Dat voelde ook goed, maar ja, daar was ik wel erg verdrietig van toen ze is overleden."

In deze paragraaf is ingegaan op spanningen die verpleegkundigen kunnen ervaren, omdat ze patiënten soms te kort doen. In het denken en handelen van verpleegkundigen is zichtbaar dat zorg die ze geven aan individuele patiënten wordt afgewogen tegen zorg voor zichzelf. Wanneer ze ervoor 'kiezen' voor zichzelf te zorgen ervaren ze dat soms als problematisch, omdat zorg voor individuele patiënten onder druk komt. Tegen hele concrete mensen die iets aan hen vragen omdat ze voor een levensbedreigende ziekte behandeld worden en opgenomen zijn, moeten verpleegkundigen 'nee' zeggen, omdat ze er zelf op een bepaald moment niet tegen kunnen met nog meer ellende geconfronteerd te worden. In de volgende paragraaf komt aan de orde dat 
deze ervaring versterkt. wordt, doordat zorg zich afspeelt binnen de context van de afdeling.

\section{CONTEXT VAN DE AFDELING}

In deze paragraaf wordt ingegaan op de context van de afdeling. Deze draagt ertoe bij dat zorg voor individuele patiënten onder druk kan komen. Er worden een aantal situaties besproken waarin dat het geval is.

\section{Zorg voor meerdere mensen}

Binnen de context van de afdeling wordt voor meerdere patiënten tegelijkertijd gezorgd. Daarom moeten verpleegkundigen keuzes maken in de zorg, die zf. als moreel ervaren. Daarnaast komt in deze paragraaf aan de orde op basis waarvan verpleegkundigen keuzes maken in de zorg.

\section{Verdelen van zorg tussen meerdere patiënten}

Verpleegkundigen zorgen voor patiënten binnen de context van de afdeling en het ziekenhuis. Soms is het druk en chaotisch op de afdeling, zodat er geen tijd is voor zorgbehoeften van alle patiënten.

Verpleegkundige: "We hebben vaak tijd te kort, waardoor we niet aan alle zorg toekomen. Daar zijn wel factoren voor te noemen, maar dat zijn niet altijd beinvloedbare factoren. Dat is vaak de werkdruk gerelateerd aan het aanwezige personeel of door slechte planning door de leiding. Daar heb je niet altijd invloed op. Het is vaak ook een situatie van overmacht. Bijvoorbeeld als door ziekte eventueel iemand wegvalt. Dat soort factoren. De situatie kan van het ene op het andere moment veranderen. Ik bedoel, als je een acute patiënt binnenkrijgt, ja dan ben je echt iedereen kwijt. Het is ook gerelateerd aan het tijdstip. Overdag. dan heb je wat meer mensen, waarmee je het kunt opvangen, maar zit je in de nachtdienst, tja."

Een nieuwe opname komt tussendoor. Een collega gaat ziek naar huis. Er is te weinig personeel. Familie vraagt aandacht. Met een patiënt gaat het plotseling heel slecht. Een extra onderzoek moet worden gedaan. Door allerlei omstandigheden komen verpleegkundigen vaak tijd tekort om alle patiënten die zorg te geven die ze nodig hebben. In deze context moeten keuzes worden gemaakt.

Het is razend druk op de afdeling. Er is een nieuwe opname binnen gekomen. De ene verpleegkundige doet de opname, terwijl de andere verpleegkundige rond rent met drinken, medicatie, om de controles te doen. Ze heeft al tegen verschillende patiënten gezegd 'straks, ik heb nu geen tijd om te 
praten'. Meneer Jansen wordt verteld zijn vraag over beenmergpuncties te onthouden. Als we bij mevrouw $x$ komen zien we dat ze in bed ligt te huilen.

De verpleegkundige gaat er nu toch even bijzitten, pakt haar hand en vraagt wat er aan de hand is.

Verpleegkundigen hebben soms geen tijd om aan het bed te zitten van patiënten om met hen te praten. Het kleine beetje tijd dat er is, wordt aan één patiënt gegeven. Andere patiënten moeten hun behoeften onthouden voor later. Zorg voor de ene patiënt wordt afgewogen tegen zorg voor andere patiënten.

In het denken en handelen van verpleegkundigen is zichtbaar dat een bepaald type zorg voorgaat. Primaire zorg en medisch-technisch handelen gaan voor. Niet omdat ze dit belangrijker vinden dan het sociale begeleidingsgebeuren, maar omdat patiënten nu eenmaal moeten eten, drinken en hun medicijnen moeten ontvangen, omdat ze anders ernstige fysieke schade oplopen.

Verpleegkundige: "Ik denk dat ik meestal aan de directe patiëntenzorg toekom. Daar probeer je wel in een dienstperiode, dus binnen die acht uur zal ik maar zeggen, voor te zorgen. Dat gedaan is wat bij ons belangrijk is, dus het verzorgen van de centrale lijnen, de medicijnen en de chemo schema's en zo. Wat er dan bij inschiet is met name het sociale begeleidingsgebeuren. Ja, dat schiet er gewoon soms bij in en dat is vaak heel erg vervelend. Je gaat dan ook met een ontevreden gevoel naar huis. Je vraagt je af wat je nu eigenlijk de hele dag gedaan hebt. En als je dan gaat evalueren, heb je eigenlijk toch een heleboel werk gedaan, maar je gaat toch ontevreden naar huis. De mens als persoon schiet er dan bij in. Dat is eventjes op de automatische piloot en dat is vervelend, zeer zeker bij deze categorie patiënten."

Verpleegkundigen moeten keuzes maken in de zorg, omdat er onvoldoende tijd is om aan de behoeften van alle patiënten tegemoet te komen. Verpleegkundigen maken dergelijke keuzes door bepaalde activiteiten voorrang te geven. Sommige activiteiten hebben een dermate dwingend karakter dat daar niet aan voorbij gegaan kan worden. Hoewel het voor patiënten heel erg vervelend kan zijn als er geen aandacht aan hun emotionele lijden wordt besteed, lopen ze geen ernstige fysieke schade op als niet direct met hen wordt gepraat. Dat is wel het geval als cytostatica niet op tijd worden aangehangen.

Hoewel verpleegkundigen het dwingende karakter van dergelijke activiteiten erkennen, wil dat niet zeggen dat ze er geen last van hebben als bepaalde activiteiten daardoor noodgedwongen naar de achtergrond verschuiven. Het draaglijk maken van de situatie voor patiënten speelt in het denken en handelen van verpleegkundigen immers een belangrijke rol. Praten met patiënten over ziekte, behandeling en opname maakt daar een belangrijk deel van uit. Niet kunnen praten met patiënten omdat er geen tijd is, ervaren verpleeg. kundigen daardoor als problexrlatisch. Verpleegkundigen geven niet alleen 
voorrang aan een bepaald type zorg, maar ook aan een bepaald type patiënten. Patiënten waar het goed mee gaat krijgen minder aandacht.

Verpleegkundige: "Ik vind dat we vaker niet toekomen aan begeleiding van mensen, maar dat heeft dan meer met drukte en onderbezetting en zo te maken. Ik denk dat er sommige gevallen zijn waarbij je gerust een hele dag met een patiënt bezig kan zijn, zowel praktisch als emotioneel. Met gesprekken en alles erom heen. Wat dat betreft denk ik dat we wel eens tekort schieten. Ja, vooral ook als het met mensen heel goed gaat. Dat speelkameraadje dat ik daarstraks zei. Ik vind dat dat er vaak bij inschiet, dat daar gewoon weinig tijd voor is. Dat patiënten vaker gewoon bellen: 'ik wou even iemand zien, ik heb de hele dag nog niemand gezien'. En dan gaat het vaak heel goed met die mensen en dan hebben mensen waar het niet goed mee gaat prioriteit. Die krijgen alle aandacht en dat vind ik erg jammer dat je niet genoeg tijd hebt om dat allemaal samen te doen."

Patiënten waar het goed mee gaat en waar verpleegkundigen bijvoorbeeld als 'tijdverdrijver' optreden - één van de activiteiten die verpleegkundigen verrichten om het leven voor patiënten draaglijker te maken - schieten er dan bijvoorbeeld bij in. Zoals ik in hoofdstuk 4 heb laten zien, vinden verpleegkundigen het belangrijk dat patiënten de tijd zo goed mogelijk doorkomen op de afdeling. Wanneer ze daar geen aandacht aan kunnen besteden, vinden ze dat ze geen goede zorg verlenen. Hoewel keuzes tussen patiënten vaak het gevolg zijn van gebrek aan menskracht, ervaren verpleegkundigen dit toch meer als een persnonlijk dan als een organisatorisch probleem.

Verplergkundige: "Heel vervelend is dat, als je aan mensen moet zeggen dat je geen tijd hebt. Heel vervelend. Daar kunnen wij uiteindelijk niets aan doen, milar toch. Of dan zeg ik 'ik kom straks' en dan lukt dat weer niet, knap lullig is dat, dan ga ik naar huis en dan denk ik ' $\mathrm{ik}$ heb niet fijn gewerkt'. Heel vervelend vind ik dat."

Verpleegkundig ervaren het als frustrerend wanneer ze door tijdsdruk niet aan behoeften van patiënten tegemoet kunnen komen, omdat zij in concrete situaties moeten kiezen.

Verpleegkundige: "Dat is toch heel erg rot als je aan iemand moet zeggen 'sorry, maar ik kan nu echt niet met u praten', omdat je je de benen onder het lijf uit aan het rennen bent. Die patiënt zit er dan maar mooi mee, en jij doet er niets aan. Dat is toch vervelend."

Managers van de afdeling kunnen praten over patiënten in het algemeen, zonder dat daar namen of gezichten bij horen. Verpleegkundigen maken de keuze tussen echte patiënten, meneer $x$ en mevrouw y, met al hun pijn en lijden. Tegen deze patiënten, die hele intensieve en pijnlijke behandelingen ondergaan en die opgenomen zijn in het ziekenhuis voor een ziekte die hun leven bedreigt, moeten verpleegkundigen zeggen dat ze geen tijd hebben. 
De problematiek van betrokkenheid die in paragraa 3 is besproken, wordt versterkt doordat verpleegkundigen binnen de context van de afdeling vaak werken onder tijdsdruk. Omdat betrokkenheid bij patiënten een belangrijke voorwaarde is voor zorg, raken verpleegkundigen gefrustreerd wanneer ze niet tegemoet kunnen komen aan zorgbehoeften van patiënten, ook al zien ze dat dit met name financiële of organisatorische kwesties zijn. Aangezien verpleegkundigen voortdurend tijd tekort komen spelen deze gevoelens van frustraties voor veel verpleegkundigen regelmatig een rol in de zorg die ze geven.

\section{Zorg voor collega's}

In het denken en handelen van verpleegkundigen is zichtbaar dat ze niet alleen moeten kiezen tussen patiënten of zichzelf, maar dat daarbij ook nog zorg voor collega's een rol speelt.

Verple'gkundige: "Ik vind het ook belangrijk als de patiënt, als je merkt dat de patiënt je nodig heeft, dat je dan ondanks dat je het heel druk hebt en heel veel dingen nog moeten, dat ik dan zeg van 'shit, ik blijf gewoon bij hem, ik moet nu even hier blijven' en dan zeg ik dadelijk wel tegen de verpleegkundige waarmee ik werk dat het niet anders gaat. Laatst had ik avonddienst met Elice. I $k$ was aan het werk en ik schoot aardig op. En Elice was aan het praten, en aan het praten . 'Och Mia' zei ze, 'nu heb ik ander half uur met de patiënt gepraat'. Ik zei 'Ja, als hij dat nodig had, dan heeft hij dat nodig' en ik zeg het wel als ik je nodig heb, dan had ik wel geroepen. Ik zeg 'maak je niet druk,' De volgende avond weer hetzelfde. We hebben zo gelachen. Ze zei 'ik durf met jou geen avonddienst meer te doen'."

Het aantal verpleegkundigen op de afdeling is afgestemd op de zorg die patiënten van verpleegkundigen moeten ontvangen. Het gaat dan om verzorgen, medicatie uitdelen, medisch-technische handelingen verrichten, en dergelijke. Het emotioneel begeleiden en ondersteunen van patiënten hoort daar ook bij. Het is echter moeilijk in te plannen hoeveel tijd daarvoor gereserveerd moet worden. Soms lijkt het met alle patiënten goed te gaan, terwijl er ook tijden zijn dat alle patiënten veel zorg en aandacht nodig hebben. Gevolg is dat volgens verpleegkundigen zorg voor individuele patiënten onder druk kan komen, omdat er te weinig tijd is om met iedereen te' praten. Daarom moeten afwegingen worden gemaakt.

Wanneer een verpleegkundige besluit iets langer bij een patiënt te blijven zitten en met hem of haar te praten, wil dat soms zeggen dat andere verpleegkundigen zorg moeten overnemen. Soms betekent een gesprek met de ene patiënt dat een collega extra belast wordt. Vooral als verpleegkundigen werken met jong gediplomeerden of leerlingen, kan het moeilijk zijn collega's e'vtra to belasten. Ook in de avonddienst en nachtdienst, als er veel minder verpleegkundigen op de afdeling aanwezig zijn dan overdag, kan zich dat voordoen. 
Ik loop mee met de avonddienst. De verpleegkundige geeft aan dat ze het een heel zware avond vindt. Van de ene kant veel patiënten met problemen, van de andere kant werken met een pas gediplomeerde die je ook niet voor alles alleen kan laten staan.

Voor jong gediplomeerde verpleegkundigen is het zwaar de verantwoordelijkheid voor de zorg op hun schouders te krijgen, maar ze willen ook niet altijd op hun meer ervaren collega's terugvallen.

Verpleegkundige: "Ik vind wel, maar dat heeft er mee te maken dat ik eerst leerling was en nu ben ik gediplomeerd, het is nu heel veel. Ik vind het nu, komt er toch veel meer op me af, toch. Die verantwoordelijkheid sowieso. Die was er eerst natuurlijk ook, maar nu helemaal. Nu heb ik toch het idee dat ik inderdaad heel veel met alles bezig ben. Als ik zeven dagen heb gewerkt ben ik helemaal leeg. Ik word wel continu geholpen door andere verpleegkundigen, maar ik moet het toch alleen doen. Ik kan toch niet altijd andere verpleegkundigen daarmee belasten."

Jonge collega's willen ervaren collega's niet steeds belasten, want die hebben het al zo druk. Ervaren collega's willen jonge collega's ondersteunen in de zorg die zij aan patiënten moeten geven. Dit stelt ervaren verpleegkundigen soms voor een dilemma. Hoewel verpleegkundigen tegemoet willen komen aan zorgbehoeften van patiënten, vinden ze het tegelijkertijd belangrijk in de gaten te houden dat het voor collega's niet te zwaar is om voor patiënten te zorgen. Ze houden ook zorgbehoeften van collega's in de gaten. De vraag is dan welke zorgbehoeften prioriteit krijgen. Die van de patiënt of die van de collega? Het is ook belangrijk goed met collega's samen te werken en ook voor elkaar te zorgen, zodat iedereen het werk ook op de langere termijn aan kan.

Verpleegkundige: "Het was druk, druk, dat geloof je niet en dan was ik samen met $P$, net op de afdeling, en die liep rond met paniek in de ogen en wat doe je dan? Dat is allemaal nog niet zo gemakkelijk gedaan. Je kunt zo'n meisje ook niet aan haar lot overlaten. Ik was helemaal kapot's avonds. Ik zei tegen mijn man 'als dit vaker gebeurt dan kunnen ze me opvegen', want je wil het natuurlijk ook goed doen voor patiënten en voor die collega, maar dat gaat gewoon allemaal niet."

In deze paragraaf is besproken dat verpleegkundigen binnen de context van de afdeling zorg voor individuele patiënten moeten afwegen tegen zorg voor anderen. Verpleegkundigen hebben ook aandacht voor hun eigen behoeften en voor die van hun collega's. Omdat verpleegkundigen veelal zorgen onder werkdruk, hebben ze voortdurend het gevoel dat ze iemand te kort doen: individuele patiënten, collega's of zichzelf. Wie er tekort gedaan wordt hangt af van allerlei factoren. In het voorgaande is bijvoorbeeld belicht dat patiënten waar het goed mee gaat vaak minder aandacht krijgen. Als het gaat om zorg voor collega's krijgen minder ervaren collega's meer aandacht dan die met 
veel ervaring. Ook de persoon van de verpleegkundige is van invloed op de vraag wie er tekort gedaan wordt. Sommige verpleegkundigen zijn geneigd zorg voor zichzelf te vergeten.

Verplergkundige: "Je hebt verpleegkundigen die zullen nooit eens sen halve vakantiedag vragen. Er zijn mensen die dat niet doen. Ook niet goed natuurlijk, maar die voelen zich zo verantwoordelijk voor patiënten. dat ze dat gewoon niet doen."

\section{Professionele of goede zorg?}

In dit hoofdstuk worden situaties besproken waarin zorg voor patiënten onder druk komt te staan. In deze paragraaf wordt dit toegespitst op de context van de afdeling. In het nu volgende komt aan de orde dat verpleegkundigen spanning ervaren wanneer het belang dat zij hechten aan betrokkenheid bij patiënten niet overeenstemt met opvattingen van professioneel zorgverlenen die binnen de organisatie circuleren.

Goede zorg is in het denken en handelen van verpleegkundigen van afdeling to onlosmakelijk verbonden met betrokkenheid bij patiënten. In de verschillende hoofdstukken is reeds aan de orde gekomen dat verpleegkundigen het belangrijk vinden betrokken te raken bij patiënten. Patiënten worden met een type problemen geconfronteerd dat daarom vraagt. Bovendien is een vertrouwensband nodig om een patiënt te leren kennen. Patiënten steunen in het proces van behandeld worden en opgenomen zijn voor een levensbedreigende ziekte, kan niet zonder als mens betrokken te raken. Goede zorg en betrokkenheid bij patiënten horen in die zin bij elkaar.

Verpleegkundige: "Goede zorg, dat is als je voor de volle procent met je hart bezig bent en ook weet waar je mee bezig bent."

Verpleegkundige: "Belangrijk is natuurlijk dat je veel weet, van ziektebeelden en behandelingen en zo en dat je handelingen goed uitvoert. Maar dat zijn eigenlijk van die dingen, die doe je gewoon. Belangrijkste vind ik, en dat vind ik ook het leukste van dit werk, is dat je met patiënten meegaat in hun proces, om het allemaal een beetje draaglijker te maken."

Het belang dat verpleegkundigen hechten aan betrokkenheid bij patiënten, is niet altijd in overeenstemming te brengen met opvattingen over professioneel zorgverlenen die binnen de afdeling of instelling circuleren.

Verplergkundige: "Die verpleegkundige, nog leerling, kwam naar me toe en zei dat een andere verpleegkundige gezegd had dat hij niet professioneel was, omdat hij het emotioneel vond om naar de begrafenis van een patiënt te gaan. Ja, en wat is dan professioneel? Dus het is om in dezelfde trant door te gaan, niet professioneel als je met een patiënt meehuilt omdat er iets ergs is gebeurd? Of omdat je met de familie huilt omdat er iemand is gestorven? Ik 
zeg, 'ik vind het heel knap dat je überhaupt kan en durft te huilen'. Ik heb tegen die jongen gezegd, 'luister, wat krijg je dan?' Ik zeg 'juist een professionele verpleegkundige is een verpleegkundige die niet emotieloos rondloopt en alles maar langs zich neerlegt wat betrekking heeft op zijn gevoel. Dan krijg je dus eigenlijk een robot'. Ik zeg 'dat zou fijn zijn, allemaal robots die klusjes doen, plas opruimen, bedden opmaken, dan houdt het toch op!' Kijk, en dan kan ik een robot ook in-programmeren wat het antwoord is op een vraag van 'god, broeder, ik heb chemotherapie gehad en wat gebeurt er met mijn beenmerg?'. Dat kan ik wel in-programmeren, maar dan ben je er natuurlijk nog niet. Die jongen vroeg zich af wat hij daar nu mee moest. Zeker omdat, toen hij zijn scriptie geschreven had, heeft hij ook een gesprek gehad en toen heeft iemand van de leiding gezegd ' $\mathrm{ja}$, niet iedereen is geschikt voor de oncologie verpleging'. In hetzelfde straatje, en dat krijg je dan van de leiding."

Verpleegkundigen van afdeling to vinden betrokkenheid bij patiënten belangrijk. Tegelijkertijd is er meningsverschil over de vraag of deze betrokkenheid wel past bij professioneel zorgverlenen. Een dergelijke opvatting wordt soms door andere verpleegkundigen of door de leiding van de afdeling tegengesproken. Goede zorg en professionele zorg vallen dan niet met elkaar samen.

Verpleegkundige: "Ik denk dat als je emotie voelt bij je werk, dat dat juist een teken is dat je goede zorg verleent. Ja, of dat professioneel is, ik weet het niet. Ik denk dat je als je op oncologie werkt en je werkt zonder emotie, ik denk dat dat onprofessioneel is. Dat vind $i k$, anderen vinden dat dan niet. Maar ik denk dat je als je laat zien dat je met gevoel werkt, dat je dan ook een betere band met een patiënt kunt krijgen, waardoor je dus weer meer uit de patiënt kunt krijgen. Als je afstandelijk zorg verleent krijg je ook minder reactie van de patiënt. Je moet dat niet forceren van 'ik moet nu emotioneel zijn, want dan krijg ik meer uit de patiënt', zo werkt dat niet. Maar ik denk niet dat het erg is als je een wat emotionelere relatie hebt met een patiënt, integendeel."

Aan de ene kant hebben verpleegkundigen het gevoel dat ze betrokken moeten raken om goede zorg te kunnen verlenen, terwijl ze tegelijkertijd een opvatting van professionele zorg aangereikt krijgen die daarmee in tegenspraak is.

In deze paragraaf is besproken dat verpleegkundigen binnen de context van de afdeling soms worstelen met hun professionele identiteit. Wat betekent goede zorg voor verpleegkundigen vanuit professionele optiek? Deze vraag kan ertoe leiden dat verpleegkundigen het gevoel hebben dat individuele zorg voor patiënten onder druk komt te staan. Mag ik wel zo betrokken raken bij deze patiënt of mag dat juist niet? En hoeveel mag ik betrokken raken? Welke betrokkenheid wordt vanuit professioneel oogpunt nog geaccepteerd? 


\section{Onvoldoende ruimte voor reflectie}

Tot besluit van dit hoofdstuk wordt besproken of en hoe binnen de context van de afdeling ruimte is voor reflectie. Waarom is reflectie zinvol? Hoeveel ruimte is er voor reflectie?

\section{Reflecteren op het handelen}

Eén van de redenen die verpleegkundigen geven waarom reflectie op het handelen zinvol is, heeft te maken met het werken in onzekerheid, zoals in hoofdstuk 5 aan de orde is gekomen. In dat hoofdstuk is besproken dat het voor verpleegkundigen niet altijd duidelijk is wat patiënten nodig hebben om het leven zo draaglijk mogelijk te maken, omdat zorgbehoeften vragen om interpretatie. Ook hebben verpleegkundigen zelf invloed op het proces van tegemoet komen aan zorgbehoeften, waarbij ze zich regelmatig afvragen of deze invloed wel goed is. Bovendien kunnen verpleegkundigen onderling van mening verschillen over wat goed is om te doen op een bepaald moment. En tot slot is in hoofdstuk 5 belicht dat zorg bijzonder veranderlijk is, waardoor verpleegkundigen zich steeds weer opnieuw moeten afvragen wat een patiënt nodig heeft. Omdat zorg inherent onzeker is, vraagt dit volgens verpleegkundigen om reflectie.

Verpleegkundige: "Ja, dat gebeurt zeker, dat je dan toch maar hoopt dat je het goede doet, want je kunt niet alles puur op kennis doen. Er zijn situaties waarin je hoopt dat je het goed doet. Dus niet verpleegtechnische problemen, maar andere dingen die spelen. Bijvoorbeeld in de relationele sfeer of bij het emotioneel gebeuren bij een patiënt. Je kunt je niet altijd overal op voorbereiden, er gebeuren altijd situaties onverwachts en dan hoop je maar dat je dat goed doet."

Verpleegkundige: "Je doet vaak iets terwijl je weet niet of je dat wel goed doet.

Daar zou je toch meer met elkaar over moeten praten."

Verplegkundige: "Soms denk je wel eens, 'waarom moet dat zo' maar daar doen we binnen ons team toch te weinig mee, dat we dat tegen elkaar zeggen.

Dat doen we eigenlijk niet snel. Jammer ook, maar ja."

Verpleegkundigen vragen zich regelmatig af of ze de situatie voor een patiënt draaglijker maken. Daarover zouden ze met andere verpleegkundigen willen praten. Reflectie op het handelen is tevens van belang omdat verpleegkundigen met artsen van mening kunnen verschillen over wat goed is om te doen voor een patiënt. Zoals in paragraaf 2 van dit hoofdstuk aan de orde is geweest, zijn er situaties waarin verpleegkundigen vinden dat er te weinig aandacht is voor de draaglijkheid van de situatie van patiënten. Op afdeling ro vindt nauwelijks reflectie plaats op dergelijke situaties. 


\section{Verpleegkundige: "We gaan hier pas om de tafel zitten als de zaak geëscaleerd}

is. Dat zou niet moeten. We moeten veel eerder al met elkaar praten over wat iedereen ervan vindt."

Wanneer verpleegkundigen met artsen overleggen staat het uitwisselen van informatie centraal en niet de reflectie op het handelen. Om spanningen niet tot conflicten te laten uitlopen, waardoor zorg voor patiënten onder druk kan komen, is onderlinge reflectie met andere zorgverleners van belang.

Verpleegkundige: "Zoals het bij die mevrouw toen is het uitgelopen tot een conflict. Dat moet natuurlijk niet. Zoiets kun je voorkomen door eerder om de tafel te gaan zitten. Dat hadden we ook moeten doen. Ik had dat moeten doen. OIm de tafel zitten en praten. Waarom doen jullie dat zo?"

Verpleegkundigen geven ook aan dat reflectie op het eigen handelen nodig is, omdat ze in de zorg waarden hanteren die voor patiënten niet altijd vanzelfsprekend zijn. In paragraaf I van dit hoofdstuk is aan de orde geweest dat verpleegkundigen veel waarde toekennen aan het bevorderen van gezondheid van patiënten. $\mathrm{Zij}$ gaan ervan uit dat een draaglijk bestaan samenhangt met een gezond bestaan. En hoewel veel patiënten dit zullen onderschrijven, geldt dat niet voor iedereen. Om waarden niet ongemerkt hun werk te laten doen, zouden ze besproken moeten worden.

Verpleegkundige: "Ik vind toch dat er verpleegkundigen zijn die hun eigen waarden laten doorspelen in de zorg die ze geven. Dat vind ik niet terecht. Je moet vanuit de patiënt redeneren. Wat is voor hem belangrijk."

Tot slot is reflectie van belang om te praten over de eigen emoties. Zoals in de voorgaande hoofdstukken is beschreven, is zorgverlening verbonden met emoties. Te proberen om de situatie voor patiënten zo draaglijk mogelijk te miken, kan niet zonder als persoon betrokken te raken. Om ervoor te zorgen dat deze emoties het verlenen van zorg niet in de weg staan, is reflectie daarop van belang.

Verpleegkundige: "Je hebt daar toch je eigen personen voor, waar je je emoties mee bespreekt. Dat is nu eenmaal zo. Hoewel, we hebben het daar wel over gehad, dat we toch meer begeleiding willen hebben. Misschien van maatschappelijk werk. Sommige mensen lopen toch op bepaalde dingen vast." Verpleegkundigen hebben ruimte nodig om over hun eigen gevoelens en emoties bij de zorg te kunnen praten, zodat ze door kunnen gaan met het geven van zorg.

\section{Supenvisie}

Verpleegkundigen van afdeling ro zouden een systeem van supervisie prefereren, om op hun handelen te reflecteren. Zo zouden zij met elkaar en onder begeleiding kunnen praten over eigen en andermans handelen en over hun emoties. 
Verpleegkundige: "Dat mag allemaal toch wat meer begeleid worden, voor ons allemaal. Er zijn ziekenhuizen waar dat wel is, dat weet ik. Er zijn twee verpleegkundigen met een scriptie bezig voor de oncologie cursus en die heet 'begeleiden van begeleiders' of nee, die heet anders 'hoe houden we elkaar heel', geloof ik. Het gaat er in ieder geval over dat wij ook begeleiding moeten krijgen. $\mathrm{Zij}$ hebben ook een enquête gehouden onder ons, of die behoefte er is en hoe we ons dat voorstellen. Zo proberen ze iets op poten te zetten."

Verpleegkundige: "Dan merk je dat het nog altijd moeilijk is om open en eerlijk tegen je collega's te zijn. Met een aantal mensen kun je dat wel en bij een aantal mensen kun je dat niet. En dan heeft niet kunnen meestal te maken met reacties van collega's. We zijn nu, twee collega's van mij zijn nu met de oncologie cursus bezig geweest en hebben ze dat als probleem opgepakt. Daar komt nu een vervolg op. We willen graag supervisie. Dat zal heel moeilijk zijn. Kritiek geven is misschien nog gemakkelijk, maar je moet ook open staan voor kritiek van anderen. Kritiek geven gaat de meeste goed af. Weet je, ze kruipen zo snel in de verdediging, en misschien is dat gedeeltelijk ook wel onbewust. Bewust zijn van je eigen fouten, dan ben je al een heel stuk op de goede weg."

\section{Reflectie van de leiding}

Verpleegkundigen zouden niet alleen met elkaar willen reflecteren op hun handelen, maar geven ook aan dat reflectie vanuit de leiding waardevol is. Ze geven daar verschillende redenen voor. Verpleegkundigen zouden graag positieve en negatieve feedback krijgen van de leiding over hun eigen functioneren, zodat ze weten of ze in het algemeen goede zorg geven. Bijvoorbeeld tijdens functioneringsgesprekken zouden dergelijke onderwerpen aan de orde kunnen komen.

Verpleegkundige: "Want ik vind het best wel belangrijk om feedback te krijgen. Ik vind dat heel belangrijk. Je bent al zo veel jaren bezig en je krijgt ook wel eens te horen wat je verkeerd doet, mar ik vind, je mag ook best wel eens te horen krijgen wat je goed doet. En ik vind ook de dingen die je verkeerd doet, vind ik ook niet slecht als je dat te horen krijgt, want ik vind dat je daarvan kan leren, van 'goh, dat moet ik beter of anders gaan doen'."

Naast officiële reflectiemomenten zou er ook tussendoor individuele aandacht kunnen zijn voor hun functioneren.

Verpleegkundige: "Nou, ik heb in mijn leerlingentijd een hoofd gehad die een kwartier voor het einde van de werktijd zei 'ga maar naar huis, het is zo'n mooi weer en jullie hebben zo lekker hard gewerkt'. Of die bepaalde ideeèn die je naar voren bracht in de overdracht ook meenam naar de artsen visite en daar dan later ook nog eens op terugkwam, zo van 'hé, dat was een goed 
idee, de dokters yonden het ook goed dat we dat eens gaan proberen'. Dan heb je ook het idee dat er naar je geluisterd wordt."

Deze reflectie is niet alleen zinvol om het eigen functioneren te kunnen toetsen, maar is ook een vorm van waardering.

Verpleegkundige: "Van patiënten krijg je vaak heel veel terug. Dat is ook hartstikke fijn. Maar je zou toch ook wel eens van de leiding willen horen dat je het goed doet. Ik heb wel zoiets van, als de leiding mijn werk niet waardeert, dan moet ik dat toch al lang te horen hebben gekregen? Ja, ik heb zoiets, dat kan niet, dat je zo lang functioneert en niks te horen krijgt. Ik vond het wel fijner toen, een aantal jaren geleden met het vroegere hoofd. Ja, die had ook persoonlijke aandacht voor jou. Zo van, als het eens een avond druk geweest is, dan de volgende dag toch even tot vijven wachten, als je dan komt en dan zeggen 'nou gisterenavond, nou verdomme wat een avond zeg'. En dan toch nog even belangstellend vragen hoe het met jou gaat."

Verpleegkundigen vinden het belangrijk dat er persoonlijke aandacht is voor hun inspanningen. Om goede zorg te geven hebben verpleegkundigen waardering nodig voor hun eigen handelen van de leiding. Deze waardering krijgen ze weliswaar vaak van patiënten, maar dat zouden ze ook graag van de leiding van de afdeling te horen krijgen.

\section{Beperkte ruimte voor reflectie}

Verpleegkundigen van afdeling ro vinden dat er in de context van de afdeling weinig mogelijkheden zijn om op hun eigen en andermans handelen te reflecteren. Ze geven daar verschillende redenen voor. Er zijn overlegmomenten, maar die zijn ervoor bedoeld om informatie uit te wisselen en niet om op het handelen te reflecteren.

Verpleegkundige: "Overdrachten duren volgens de leiding al te lang. Die moeten korter, zakeliiker, maar jia, probeer dat maar eens voor elkaar te krijgen.

Iedereen moet toch ergens zijn ei kwijt."

In het regelmatige overleg tussen verpleegkundigen onderling en met andere zorgverleners staat vooral het uitwisselen van informatie centraal. Het gaat erom een beeld te krijgen van de situatie van patiënten en van vragen en behoeften die daarmee samenhangen. Voor reflectie op het handelen zijn dergelijke overlegmomenten niet bedoeld. Er is ook geen mogelijkheid tot reflectie, omdat daarvoor de geschikte omgeving ontbreekt.

Verpleegkundige: "Koffiedrinken mag niet meer op de afdeling. En dat zijn momenten dat je contact hebt met collega's. Je maakt een hoop flauwekul, maar iemand vertelt ook wat hij heeft meegemaakt of waar hij mee zit. Bij de overdracht is maar een half uur de tijd. Daar is dan geen ruimte voor dat soort zaken. Overdrachten, die duren altijd te lang. Ja en je kunt het korter maken. Maar dan moet je op een ander tijdstip plannen dat je het gezellige 
samenzijn plant. En ook, er zijn zo veel dingen waar je met elkaar eigenlijk over moet praten. De koffiekamer die we nu hebben, dat is niets. De éen wil roken en de ander niet."

In eerdere tijden gebruikten verpleegkundigen vooral de koffiepauzes voor het bespreken van het eigen handelen en emoties. In de nieuwbouw mag dat echter niet meer, omdat voor pauzes officiële ruimtes in gebruik zijn genomen. Omdat er onder verpleegkundigen rokers en niet-rokers zijn en ook omdat andere zorgverleners aanwezig zijn in deze omgeving, kunnen pauzes niet meer gebruikt worden voor reflectie.

Verpleegkundige: "De leiding moet zien dat er behoefte aan is. Bijvoorbeeld proberen om ons weer gezamenlijk te laten pauzeren, want daar speelt zich gewoon heel veel af. Daar werd gewoon gepraat over meneer Janssen, van 'wat vindt jij daar nu van?'. Oké. jammer dat het onder de koffiepauze moet. Er zijn ook verpleegkundigen die zeggen van 'nee, nu effe niet'. Maar nu ga je gesplitst pauzeren met een heel klein groepjes, bij mensen van andere afdelingen zit je dan vaak in dat hok."

Niet alleen is er geen omgeving waarin op de zorg gereflecteerd kan worden. Ook zijn er geen structurele reflectiemomenten ingebouwd.

Verpleegkundige: “Maar een hoofd staat eigenlijk heel ver van de verpleging af. Ons hoofd heeft twee afdelingen. Dus hij heeft dan toch niet zo direct contact met het afdelingsgebeuren. Dus eigelijk zie je hem alleen als er iets is in verband met je dienst. Ook als er werkelijk iets is. Maar ja, tot nu toe heb ik dat niet gehad. En we hebben dus ook nog geen functioneringsgesprekken gehad, dus, nee, helaas niet. Ja, dat vind ik ook jammer voor mezelf."

Doordat het hoofd van de afdeling weinig betrokken is bij de dagelijkse zorgverlening en bovendien om welke reden dan ook geen functioneringsgesprekken heeft gevoerd, is er nauwelijks ruimte voor reflectie of gelegenheid tot het uiten van waardering. Verpleegkundigen ervaren dat als een tekort. Zonder reflectie kan het eigen handelen nauwelijks aan positieve en negatieve feedback worden onderworpen en kunnen emoties niet worden gespuid, terwijl dat wel zinvol is om de situatie voor patiënten én voor verpleegkundigen zo draaglijk mogelijk te maken.

In deze paragraaf zijn morele ervaringen van verpleegkundigen besproken in relatie tot de context van de afdeling. Hoe beïvloedt de afdeling de handelingsruimte van verpleegkundigen? Vanuit dit perspectief is besproken dat deze afdeling op verschillende manieren van invloed is op de zorg die verpleegkundigen geven. Verpleegkundigen moeten bijvoorbeeld keuzes maken tussen individuele patiënten. Door gebrek aan menskracht kan niet aan alle patiënten díe zorg gegeven worden die deze nodig hebben. Een ander aspect van de afdeling dat van invloed is op de zorg die verpleegkundigen geven, heeft van doen met opvattingen over professioneel zorgverlenen. Soms han- 
teren bepaalde verpleegkundigen of de leiding van de afdeling een opvatting over professioneel zorgverlenen waarin weinig ruimte is voor betrokkenheid, waardoor verpleegkundigen zich afvragen of de zorg die zij geven wel professioneel genoeg is. Tot slot beïnvloedt de omgeving de mogelijkheid voor reflectie. Doordat er zowel figuurlijk als letterlijk (een kamer) geen ruimte voor is, zijn verpleegkundigen nauwelijks in de gelegenheid om op het eigen of andermans handelen en op emoties te reflecteren, terwijl ze dat wel zinvol zouden vinden.

\section{CONCLUSIE}

In dit hoofdstuk zijn situaties besproken waarin volgens verpleegkundigen de draaglijkheid van de situatie van patiënten in het geding is. Er zijn verschillende situaties geïdentificeerd waarin dit volgens verpleegkundigen het geval is. Wat het betekent om de situatie voor patiënten zo draaglijk mogelijk te maken is daardoor op een specifieke manier belicht.

Op de eerste plaats is aan de orde gekomen dat verpleegkundigen en patiënten het niet altijd eens zijn over de vraag wat een draaglijk bestaan is. Daarom verrichten verpleegkundigen allerlei activiteiten die erop gericht zijn met patiënten tot overeenstemming te komen over wat goed is om te doen op een bepaald moment. Op de tweede plaats is besproken dat het handelen van verpleegkundigen erop gericht is ruimte te creëren voor hun opvattingen over wat goed is om te doen in relatie tot artsen. Het behandelbeleid van artsen is van invloed op bewegingsvrijheid van verpleegkundigen om die zorg te geven die ze als goed ervaren. Wanneer ze deze bewegingsvrijheid te beperkt vinden, proberen ze deze op allerlei manieren op te rekken. Zowel in relatie tot patiënten als in relatie tot artsen, is het handelen van verpleegkundigen erop gericht conflicten te voorkomen. Op de derde plaats is belicht dat zorg voor individuele patiënten gegeven wordt onder omstandigheden waar verpleegkundigen ook voor zichzelf moeten zorg. Zorg voor patiënten kan onder druk komen, omdat betrokkenheid bij patiënten verbonden is met het risico dat zorg te zwaar wordt. Hoewel verpleegkundigen erkennen dat zorg voor zichzelf nodig is ervaren ze het toch als problematisch, wanneer zorg voor patiënten daardoor onder spanning komt te staan. Op de vierde plaats is de zorg die verpleegkundigen geven besproken binnen de context van de afdeling. Daardoor werd zichtbaar dat zorg voor individuele patiënten moet worden afgewogen tegen zorg voor andere patiënten. Hoewel verpleegkundigen zien dat deze situatie het gevolg is van organisatorische problemen of van werkdruk, ervaren ze het toch als frustrerend als ze tegen patiënten die angstig en onzeker zijn moeten zeggen dat deze hun behoeften aan zorg moeten opschorten. 
De context van de afdeling beperkt soms de bewegingsvrijheid van verpleegkundigen, omdat ze zich afvragen of betrokkenheid bij patiënten past bij opvattingen van professioneel zorgverlenen die binnen de afdeling en instelling circuleren. En tot slot is in dit hoofdstuk besproken dat de ruimte voor reflectie op eigen en andermans handelen en emoties beperkt is, waardoor zorg voor individuele patiënten onder druk kan komen te staan. Niet alleen omdat er te weinig gesproken wordt over de vraag of de geboden zorg wel goed is, maar ook omdat verpleegkundigen hun emoties moeten kunnen uiten en waardering van de leiding nodig hebben om te kunnen blijven zorgen voor patiënten.

In de empirische hoofdstukken zijn morele ervaringen van verpleegkundigen van afdeling Io op een specifieke manier inzichtelijk gemaakt. Op de eerste plaats door te bestuderen welke zorgbehoeften zij bij patiënten signaleren om hun leven zo draaglijk mogelijk te maken. Op de tweede plaats door te bestuderen hoe ze aan deze behoeften tegemoet proberen te komen. Op de derde plaats door op zoek te gaan naar situaties waarin zich moeilijkheden, problemen of belemmeringen voordoen, wanneer verpleegkundigen proberen de situatie voor patiënten zo draaglijk mogelijk te maken. Het proces van zorgverlenen is hierdoor op een specifieke manier belicht. Tot besluit van dit boek worden deze ervaringen van verpleegkundigen in verband gebracht met de ethische theorieën die in hoofdstuk 2 zijn besproken, met name zorgethiek. 



\section{MORELE ERVARINGEN EN VERPLEEGKUNDIGE}

\section{ETHIEK}

Het doel van de studie waarvan in dit boek verslag wordt gedaan, is het expliciteren van morele ervaringen van verpleegkundigen met de dagelijkse zorgverlening. Morele ervaringen worden in deze studie gezien als ervaringen die verbonden zijn met opvattingen van verpleegkundigen van goede zorg, als ook de manieren waarop ze deze proberen te geven en de problemen die ze daarbij tegenkomen.

Om morele ervaringen van verpleegkundigen zichtbaar te maken is gebruik gemaakt van het theoretisch kader van de zorgethiek. In hoofdstuk 2 zijn verschillende stromingen, die binnen de verpleegkundige ethiek op grote lijnen te onderscheiden zijn, naast elkaar gezet en bestudeerd aan de hand van de vraag welke perspectief het meest bruikbaar is om morele ervaringen van verpleegkundigen met dagelijkse zorgverlening inzichtelijk te maken. Het theoretisch kader van de zorgethiek bleek daarbij de meeste aanknopingspunten te bieden. Dat heeft consequenties voor de wijze waarop morele ervaringen van verpleegkundigen van afdeling to in de empirische hoofdstukken in beeld zijn gebracht. Er is namelijk niet gezocht naar kwesties waarin gangbare ethische principes met elkaar botsen. Het proces van dagelijkse zorgverlening is bestudeerd. Onderzocht is tegen welke kwesties verpleegkundigen bij de dagelijks zorg aanlopen, bijvoorbeeld wanneer ze patiënten helpen met wassen, aankleden, eten of drinken, wanneer ze patiënten informeren over de dagelijkse gang van zaken op de afdeling of over ziekte, behandelingen en onderzoeken, als ook wanneer ze medisch-technische handelingen uitvoeren of wanneer ze met patiënten praten over de betekenis die het ziek zijn voor. hen heeft. Bij dergelijke kwesties is aangehaakt, om morele ervaringen van verpleegkundigen zichtbaar te maken. Het zorgethisch perspectief is ook gehanteerd bij de meer gangbare en in het oog springende ethische kwesties die op afdeling ro voorkwamen. Ook dan was het uitgangspunt de vraag wat voor verpleegkundigen in de dagelijkse zorgverlening, goede zorg betekende en tegen welke problemen ze aanliepen om deze te geven. Wat is goede zorg voor patiënten die om euthanasie hebben gevraagd, patiënten die morfine toegediend krijgen of patiënten waarvoor een onduidelijk reanimeer beleid is 
afgesproken? Tegen welke problemen lopen verpleegkundigen in de dagelijkse zorg aan, wanneer ze aan deze patiënten goede zorg proberen te geven?

In de empirische hoofdstukken is verslag gedaan van de inzichten die zijn verkregen van morele ervaringen van verpleegkundigen met dagelijkse zorgverlening, door vanuit zorgethisch perspectief een kwalitatief onderzoek te verrichten op een hematologie oncologie afdeling van een academisch ziekenhuis (afdeling ro). Dagelijkse zorg is daarbij bestudeerd aan de hand van de volgende vragen:

Aan welke zorgbehoeften die samenhangen met het in stand houden of herstellen van de wereld van patiënten proberen verpleegkundigen tegemoet te komen, zodat zij er zo goed mogelijk in kunnen leven?

Hoe proberen verpleegkundigen tegemoet te komen aan zorgbehoeften die samenhangen met het in stand houden of herstellen van de wereld van patiënten, zodat zij or zo goed mogelijk in kunnen leven?

In welke situaties komen verpleegkundigen moeilijkheden, problemen en belemmeringen tegen, juist omdat ze erop gericht zijn patiënten te ondersteunen bij het in stand houden of herstellen van hun wereld, zodat zij er zo goed mogelijk in kunnen leven?

In dit hoofdstuk worden de consequenties van de bevindingen uit de empirische hoofdstukken voor de verpleegkundige ethiek besproken. Welke thema's en vragen behoeven ethische reflectie? Hierbij wordt er van uitgegaan dat verpleegkundige ethiek niet alleen in staat moet zijn om morele ervaringen van verpleegkundigen met dagelijkse zorgverlening inzichtelijk te maken, zoals dat in de empirische hoofdstukken met behulp van zorgethiek is gedaan. Verpleegkundige ethiek moet ook bruikbaar zijn om nader te bepalen wat verpleegkundigen zélf nodig hebben om goede zorg te geven of welke contexten belemmerend of bevorderend werken, wanneer verpleegkundigen proberen de situatie voor patiënten zo draaglijk mogelijk te maken. Verpleegkundige ethiek is niet beperkt tot het beschrijven van ervaringen, maar kan deze ook verder uitwerken en aanscherpen. Hierbij wordt niet verondersteld dat het mogelijk is vanuit een ethisch perspectief eenduidige standaarden aan te bieden, om de zorg die verpleegkundigen geven vanuit ethisch perspectief aan af te meten. De vraag wat goed is om te doen voor een patiënt, is immers contextafhankelijk. Dat wil niet zeggen dat kritiek niet mogelijk is, maar wel dat deze gebaseerd moet zijn op een gedetailleerd inzicht in de situatie vanuit het perspectief van betrokkenen. In dit hoofdstuk wordt - vanuit morele ervaringen van verpleegkundigen - daarom, aan verpleegkundige 
ethiek, een aantal onderwerpen aangereikt voor nadere studie. Doel daarvan is om vanuit verpleegkundige ethiek, morele ervaringen van verpleegkundigen met dagelijkse zorgverlening diepgaand te kunnen begrijpen, te ondersteunen, ervan te leren en er waar nodig kritische vragen bij de stellen.

In dit hoofdstuk worden een aantal thema's aangegeven, die in het kader van verpleegkundige ethiek verder bestudeerd en overdacht kunnen worden. Deze thema's worden in eerste instantie vanuit het empirische materiaal besproken. Getoond wordt waarom deze onderwerpen kenmerkend zijn voor morele ervaringen van verpleegkundigen van afdeling Io. Vervolgens worden verbanden gelegd met literatuur over verpleegkundige ethiek en met name zorgethiek, omdat dit perspectief ook gebruikt is om morele ervaringen van verpleegkundigen met dagelijkse zorgverlening inzichtelijk te maken. In dit hoofdstuk wordt nagegaan of en hoe zorgethiek aandacht besteedt aan de thema's die uit morele ervaringen van verpleegkundigen van afdeling Io naar voren zijn gekomen. Hierbij wordt onderscheid gemaakt tussen zorgethische literatuur van binnen en buiten de verpleging, wanneer daarin bepaalde accenten anders worden gelegd of onderwerpen al dan niet worden besproken. De twee andere verpleegkundig ethische perspectieven die in hoofdstuk 2 zijn bestudeerd, namelijk verpleegkundige principe-ethiek en verpleegkundige deugdethiek, worden bij de bestudering betrokken wanneer dat zinvol is om thema's verder uit te diepen.

In paragraaf $\mathrm{I}$ wordt een thema besproken dat met name in hoofdstuk 4 tot uitdrukking is gekomen, namelijk dat dagelijkse zorg een morele lading kan hebben omdat daarin opvattingen van goede zorg een rol in spelen én omdat allerlei technische en praktische handelingen die verpleegkundigen verrichten ook ingezet worden om de situatie voor patiënten zo draaglijk mogelijk te maken. In paragraaf 2 wordt een tweede thema besproken dat uit morele ervaringen van verpleegkundigen van afdeling ro naar voren is gekomen, namelijk 'zorgrationaliteit'. Met name in hoofdstuk 5 is zichtbaar geworden dat het signaleren van en tegemoet komen aan zorgbehoeften van patiënten zich kenmerkt door een eigen zorgrationaliteit waarin doen, kennen, voelen, redeneren en overleggen samenkomen. In paragraaf 3 wordt het thema 'betrokkenheid' bestudeerd, dat in dit onderzoek als centraal kenmerk van morele ervaringen naar voren is gekomen. In dit empirische onderzoek is zichtbaar geworden dat 'betrokkenheid' op verschillende manieren een rol speelt bij het draaglijker maken van de situatie voor patiënten. Een volgend onderwerp voor verpleegkundige ethiek dat uit de empirische studie naar voren is gekomen, is het streven naar een gezamenlijk gedragen zorgproces. Om de situatie voor patiënten draaglijker te maken, is het van belang dat zowel patiënten als verpleegkundigen zich kunnen vinden in de invulling die het zorgproces krijgt. In paragraaf 4 wordt dit onderwerp besproken. Daarbij 
worden ook de grenzen van bemoeienis met het leven van patiënten onderzocht. In paragraaf 5 komt de kwestie van macht aan de orde. Het geven van goede zorg is mede afhankelijk van de ruimte die verpleegkundigen daarvoor krijgen. Behandelbeleid van artsen en de context van de afdeling zijn bijvoorbeeld van invloed op de ruimte die verpleegkundigen ervaren om zorg te geven, die gericht is op het draaglijker maken van de situatie voor patiënten.

\section{DE MORELE LADING VAN DAGELIJKSE ZORG}

Een centraal kenmerk van zorg dat uit morele ervaringen van verpleegkundigen van afdeling Io naar voren is gekomen, is dat dagelijkse zorg moreel geladen is. Dat wil niet zeggen dat alles wat verpleegkundigen doen moreel is. Zorgen wordt moreel, wanneer dit door verpleegkundigen verbonden wordt met opvattingen van goed en kwaad, juist en onjuist handelen of zoals uit dit onderzoek naar voren komt - met het draaglijker maken van het bestaan voor patiënten. In deze paragraaf wordt de morele lading van zorg op twee manieren verder geanalyseerd en uitgewerkt. Eerst wordt besproken dat de op de afdeling algemeen aanvaarde opvattingen over goede zorg positieve en negatieve effecten hebben. Vervolgens wordt het morele karakter van zorgactiviteiten aan de orde gesteld. In het tweede deel van deze paragraaf worden deze bevindingen in verband gebracht met verpleegkundige ethiek, met name de zorgethiek.

\section{De morele lading van opvattingen van goede zorg en zorgactiviteiten}

De morele lading van zorgen komt op twee manieren in het empirische materiaal tot uitdrukking. Op de eerste plaats omdat verpleegkundigen opvattingen van goede zorg hanteren, die van zijn invloed zijn op de manier waarop zorgbehoeften worden gesignaleerd en gehanteerd om de situatie voor patiënten draaglijker te maken. Op de tweede plaats omdat het draaglijker maken van de situatie van patiënten zich afspeelt binnen de zorgenactiviteiten zelf.

\section{Opvattingen van goede zorg}

Zorgen is moreel, omdat verpleegkundigen daarbij hun opvattingen over goede zorg inzetten. Deze ideeën van goede zorg worden deels in opleidingen en bijscholingen ontwikkeld, waarbij verpleegkundigen maatschappelijke en professionele standaarden van goede zorg krijgen aangereikt. Daarnaast ontwikkelen verpleegkundigen opvattingen over het goede, tijdens het zorgen voor een specifieke patiëntencategorie. Doordat verpleegkundigen in de 
zorg geconfronteerd worden met patiënten die intensieve behandelingen ondergaan, vinden ze het belangrijk om onder andere fysiek lijden van patiënten te verminderen. Omdat verpleegkundigen zorgen voor patiënten die opgenomen zijn in het ziekenhuis waarbij hun leven als het ware van hen wordt overgenomen, vinden ze het belangrijk om patiënten te helpen nog enige controle te houden over de invulling van de eigen tijd. Omdat verpleegkundigen in de dagelijkse zorg met patiënten geconfronteerd worden die een aanzienlijke kans hebben om dood te gaan, vinden ze het waardevol om oog te hebben voor angst en onzekerheid van patiënten. Verplegen is moreel, wanneer verpleegkundigen in de zorg hun opvattingen van goede zorg inzetten.

Opvattingen van goede zorg hebben invloed op de wijze waarop verpleegkundigen zorgbehoeften identificeren en hanteren om de situatie voor patiënten draaglijker te maken. Omdat verpleegkundigen het in het algemeen belangrijk vinden dat patiënten geen fysieke pijn lijden, zijn ze alert op zorgbehoeften die daarmee samenhangen. Ideeën over goede zorg die verpleegkundigen in de praktijk hanteren, richten hun blik. Dat is enerzijds positief, omdat verpleegkundigen daardoor alert zijn op zorgbehoeften en deze eerder zullen waarnemen. Anderzijds kunnen deze ideeën over goede zorg de blik ook vernauwen. Dat is bijvoorbeeld in hoofdstuk 6 aan de orde gekomen. Daar is besproken dat verpleegkundigen zich in bepaalde omstandigheden afvragen of de behandeling nog zin heeft. Veelal zorgen ze voor patiënten die vechten voor hun leven. Deze ervaring kleurt hun blik. Daardoor kan er pas ruimte komen voor vragen en behoeften van patiënten die samenhangen met het stoppen van behandeling, wanneer een patiënt fysiek ernstig lijdt en wanneer verpleegkundigen zelf niet meer geloven dat de behandeling zal slagen en ook de patiënt zelf aangeeft er geen heil meer in te zien. Verpleegkundigen vinden het belangrijk en waardevol om de behandeling die patiënten krijgen optimaal te ondersteunen. Dat heeft als consequentie dat zorgbehoeften van patiënten die niet passen in dit perspectief, niet zonder meer worden gezien of soms onvoldoende serieus worden genomen.

Het is zinvol om in het kader van verpleegkundige ethiek zicht te hebben op opvattingen van verpleegkundigen over goede zorg. Wanneer verpleegkundigen zich meer van die opvattingen bewust zijn, kunnen ze deze sterker uitdragen in de praktijk. Daarnaast is het van belang om de vanzelfsprekendheid van dergelijke opvattingen van goede zorg ter discussie te stellen, in specifieke zorgsituaties. Aan de ene kant leiden deze opvattingen van goede zorg er namelijk toe dat verpleegkundigen weten waarop ze moeten letten waardoor ze zorgbehoeften sneller kunnen waarnemen. Aan de andere kant kunnen deze ideeën over goede zorg de blik vernauwen, wat ertoe kan leiden dat zorgbehoeften niet worden waargenomen of dat een patiënt bepaalde 
zorgbehoeften krijgt opgedrongen. Opvattingen van goede zorg die verpleegkundigen hanteren binnen een specifieke praktijk moeten daarom, in het kader van zorg voor individuele patiënten, ter discussie kunnen staan. Verpleegkundige ethiek zou behulpzaam moeten zijn bij het verder uitwerken en ter discussie stellen van opvattingen van goede zorg die verpleegkundigen binnen specifieke praktijken hanteren.

\section{Morele zorgactiviteiten}

Dagelijkse zorg is niet alleen moreel geladen omdat verpleegkundigen hun ideeën over goede zorg inzetten. Zorgen kan ook moreel genoemd worden, orndat verpleegkundigen bij het verrichten van concrete zorgactiviteiten rekening houden met de draaglijkheid van het bestaan van patiënten.

Zorgactiviteiten zijn op de eerste plaats als moreel te typeren, wanneer deze expliciet worden uitgevoerd om de situatie voor een patiënt draaglijker te maken. Zoals in hoofdstuk 4 zichtbaar is geworden, proberen verpleegkundigen bijvoorbeeld fysieke pijn en lijden van patiënten te verminderen door hen lichamelijke zorg te geven. Een washandje op het voorhoofd, haren wassen, nagels knippen, een extra kussen onder het hoofd, om de situatie voor een patiënt draaglijker te maken. Verzorgende handelingen kunnen de draaglijkheid van de situatie bevorderen. Dat geldt ook voor het verstrekken van informatie. Soms wordt met een patiënt gepraat om informatie te geven over ziekte en behandeling, bijvoorbeeld om de patiënt in te lichten over een onderzoek en deze er op voor te bereiden dat er bepaalde medicatie moet worden ingenomen of dat het eten van voedsel achterwege gelaten moet worden. Soms wordt informatie expliciet verstrekt om de situatie voor een patiënt draaglijker te maken. Verpleegkundigen gaan er dan vanuit dat patiënten deze informatie nodig hebben, om greep te houden op hun situatie of om emotioneel lijden te verminderen. Zorgactiviteiten die ogenschijnlijk niets met ethiek van doen hebben, zoals patiënten wassen, goed in bed zetten of informatie geven om hen op een onderzoek voor te bereiden, zijn moreel wanneer ze erop gericht zijn de situatie voor patiënten draaglijker te maken. $\mathrm{Bij}$ de bestudering van morele ervaringen van verpleegkundigen van afdeling Io werd daarbij zichtbaar dat zij hun zorgende activiteiten niet zo zeer richten op grootse kwesties, zoals de zin van het leven of betekenis van lijden en dood. Morele zorgactiviteiten van verpleegkundigen zijn er vooral op gericht dagelijkse morele kwesties te hanteren, zoals pijn verlichten, patiënten te helpen om angst en onzekerheid te hanteren, relaties te ondersteunen door wederzijds begrip te creëren, paniek te voorkomen, heimwee te bestrijden, de omgeving vertrouwder en gezelliger maken, pijnmedicatie te organiseren, patiënten te steunen om greep te houden op hun situatie, patiënten de gelegenheid te geven tijd naar eigen inzicht te besteden of om verveling te 
voorkomen. ${ }^{t}$ Verpleegkundigen verrichten vooral verzorgende handelingen, om de dagelijkse situatie voor patiënten zo draaglijk mogelijk te maken.

Op de tweede plaats kan zorgen moreel worden genoemd, wanneer verpleegkundigen bij het uitvoeren van verzorgende of medisch-technische handelingen rekening houden met de vraag hoe ze de draaglijkheid van de het bestaan van patiënten al dan niet bevorderen. Wanneer verpleegkundigen bij het uitvoeren van dergelijke handelingen rekening houden met de invloed die ze hebben op de draaglijkheid van het bestaan van patiënten, hebben deze activiteiten een morele lading. Wanneer verpleegkundigen een injectie toedienen, houden ze tegelijkertijd rekening met ervaringen van patiënten. Wat betekent het voor patiënten om bepaalde medicatie toegediend te krijgen? Ervaart een patiënt dat als emotioneel ingrijpend of veroorzaakt deze ingreep fysieke pijn? Het informeren van patiënten is veelal niet een louter technisch gebeuren, waarin slechts informatie wordt uitgewisseld. Uit de wijze waarop verpleegkundigen informatie doseren spreekt aandacht voor de reikwijdte die deze informatie heeft in het leven van patiënten. Ze zien hoe ingrijpend bepaalde informatie voor hen kan zijn en stemmen de wijze waarop ze informatie geven daarop af. Dat wil niet zeggen dat verpleegkundigen bij iedere handeling die ze verrichten zich afvragen wat dit betekent voor de draaglijkheid van de situatie van patiënten. Sommige handelingen worden routinematig uitgevoerd. Verpleegkundigen hebben met name aandacht voor gevoelens, emoties en ervaringen van patiënten, als er zich problemen voordoen. Bijvoorbeeld als patiënten fysieke pijn lijden of verdrietig zijn. Het verrichten van een verzorgende en medisch-technische handelingen heeft een morele lading, wanneer verpleegkundigen specifieke gevoelens, emoties en ervaringen van patiënten verdisconteren in het uitvoeren er van.

Op basis van het voorgaande kan worden geconcludeerd dat zorgactiviteiten op twee manieren als ethisch te typeren zijn: op de eerste plaats als ze expliciet verricht worden in het kader van het draaglijker maken van het bestaan voor patiënten; op de tweede plaats wanneer verpleegkundigen bij het verrichten van verzorgende en medisch-technische handelingen aandacht hebben voor gevoelens, emoties en ervaringen van patiënten. In het denken en handelen van verpleegkundigen van afdeling to kunnen deze twee typen morele activiteiten veelal niet los van elkaar gezien worden. Wanneer verpleegkundigen patiënten wassen, houden ze rekening met gevoelens van patiënten die daarmee samenhangen. Daarbij kan de handeling er tegelijkertijd op gericht zijn fysieke troost te bieden. Deze twee typen morele activiteiten zijn in deze paragraaf onderscheiden, om het morele karakter van zorgactiviteiten verder uit te diepen en te verhelderen. 


\section{De morele lading van zorg binnen de verpleegkundig ethiek}

Zorgen en ethiek zijn in het denken en handelen van verpleegkundigen onlosmakelijk met elkaar verbonden. Op basis van deze verbondenheid tussen zorgen en ethiek wordt in dit onderzoek beargumenteerd dat verpleegkundige ethiek aandacht moet hebben voor opvattingen van verpleegkundigen van goede zorg en voor het morele karakter van zorgactiviteiten, zoals die zich voordoen binnen specifieke zorgpraktijken. In het tweede deel van deze paragraaf wordt deze bevinding besproken in het licht van zorgethische literatuur. Daarbij wordt onderscheid gemaakt tussen zorgethische literatuur van buiten (algemeen ethische en feministische literatuur) en binnen de verpleging. Reden daarvoor is dat hierin de aandacht voor dit onderwerp verschillend is.

\section{Opvattingen van verpleegkundigen over goede zorg}

In de zorgethiek wordt ervoor gepleit om morele ervaringen van betrokkenen te betrekken bij het bespreken van morele kwesties. Dit pleidooi wordt ondersteund door een uitwerking van het concept zorg als praktijk, dat uit de feministische literatuur afkomstig is. Dit concept wordt door Sarah Ruddick (1980) geïntroduceerd in het feministisch debat. Ruddick omschrijft 'praktijk' als een 'collectieve menselijke handelingsvorm', die te onderscheiden is van andere praktijken door zijn doel en de daaruit voortvloeiende vereisten die gesteld worden aan personen die zich in hun handelen verbinden aan het vervullen van die doelen. Paardrijden en het doen van biochemisch onderzoek vereisen andere houdingen en cognitieve deugden dan het verzorgen van bejaarden met de ziekte van Alzheimer. Deze uitwerking van het praktijkbegrip wordt door zorgethici opgepakt en aangevuld. ${ }^{2} \mathrm{Zij}$ gaan er vanuit dat ook het doel van zorg afhankelijk is van specifieke zorgpraktijken. ${ }^{3}$ Wat in de ene praktijk als goed wordt ervaren, staat in een andere praktijk ter discussie. Sevenhuijsen (I996) stelt dat opvattingen van goede zory worden neergelegd in het handelen in praktijken, terwijl handelen in praktijken op hun beurt door opvattingen van het goede wordt geïnspireerd. Goede zorg komt tot uitdrukking in het handelen en oordelen van betrokken actoren. Terwijl dat wat als goede zorg wordt aangemerkt binnen een praktijk, het handelen van betrokkenen beïnvloedt.

Zorg opvatten als praktijk veronderstelt dat zowel opvattingen van goede zorg verbonden zijn met specifieke zorgpraktijken, als ook de deugden en vardigheden die nodig zijn om deze zorg te geven. Gezien deze opvattingen van zorg als praktijk, is het volgens zorgethici van belang om betrokkenen zelf aan het woord te laten om inzicht te verwerven in morele kwesties die spelen binnen specifieke zorgpraktijken. Wat als moreel probleem geldt en wat een goede en werkbare oplossingen is, moet besproken worden vanuit de speci- 
fieke situatie waarin betrokkenen zich bevinden. Zorgethici stellen daarom voor om door middel van kwalitatieve onderzoeksmethoden inzicht te verwerven in de gedaante die morele kwesties binnen specifieke praktijken aannemen en in de wijze waarop betrokkenen deze hanteren om de situatie werkbaar en leefbaar te maken." Morele kwesties kunnen volgens Sevenhuijsen (1996) bijvoorbeeld zichtbaar gemaakt worden door betrokkenen te stimuleren verhalen te vertellen. Morele verhalen (kleine verhalen over zorg) kunnen worden gezien als middel om inzicht te verwerven in morele problematiek.

De conclusie in dit onderzoek dat dagelijkse zorg een morele lading heeft en dat verpleegkundige ethiek daarom aandacht moet hebben voor opvattingen van goede zorg van verpleegkundigen binnen specifieke praktijken, sluit aan bij de opvattingen van zorgethiek over zorg als praktijk. Het denken in termen van 'praktijken' kan gebruikt worden om morele ervaringen van verpleegkundigen verder aan te scherpen en uit te werken. Dit biedt bijvoorbeeld aanknopingspunten om te reflecteren op de wijze waarop behoeften binnen specifieke contexten worden waargenomen. Sevenhuijsen (1996) zegt daarover het volgende:

"Waarnemingen van zorgbehoeften worden niet regelrecht bepaald door die behoeften of door een of andere noodzaak. Zij worden bemiddeld door de taal waarin we daarover spreken en door de vocabulaires die we van toepassing achten op zorgpraktijken. Zij worden ook gestempeld door de psychische of de emotionele disposities van betrokkenen of door de psychodynamische interactiepatronen waarin zij zijn verwikkeld." (p. 34).

Zorgbehoeften zijn het resultaat van een interactie tussen betrokkenen, die daar als persoon invloed op hebben. Zowel de zorggever als de zorgontvanger bepalen mede welke vorm zorgbehoeften aannemen. Ook de taal waarin over zorgbehoeften gesproken wordt, is van invloed op de gedaante die deze aannemen. Bijvoorbeeld wanneer verpleegkundigen ervan uitgaan dat patiënten behoefte hebben aan privacy, dan wordt dit in het kader van de verpleegkundige principe-ethiek besproken in een taal van rechten en plichten. Patiënten hebben recht op privacy en daarom hebben verpleegkundigen de plicht om te kloppen op deuren voordat ze naar binnen gaan en ze moeten bedgordijnen dichttrekken wanneer er gewassen wordt. In een taal van principes wordt de behoefte aan privacy op een bepaalde manier ingevuld. Daardoor wordt mede de richting bepaalt waarin naar oplossingen wordt gezocht. In een taal van zorg wordt op een andere manier nagedacht over de behcefte aan privacy van patiënten. Het gaat er dan niet om waar patiënten in het algermeen recht op hebben, maar om wat ze in hun specifieke omstandigheden nodig hebben om hun wereld als leefbaar te ervaren. Sommige patiënten hebben het nodig dat er geklopt wordt op hun deur. Voor andere patiënten kan dat echter bete- 
kenen dat ze zich minder 'thuis' voelen, wanneer er voortdurend op hun deur wordt geklopt. Sommige patiënten kunnen privacy nodig hebben, bijvoorbeeld in de vorm van een één-persoonskamer, om de situatie als draaglijker te ervaren. Voor andere patiënten is hun situatie juist prettiger wanneer ze niet alleen zijn op hun kamer, maar deel uitmaken van een groepje patiënten die gezelligheid met zich meebrengen, waarmee ze informatie kunnen uitwisselen of problemen bespreken. Patiënten kunnen ook behoefte hebben aan privacy om het onderlinge contact met familie te versterken en daarvoor juist wel een aparte kamer nodig hebben. De taal. wa.arin over behoeften, zoals de behoefte aan privacy, wordt gesproken bepaalt mede de inhoud ervan, als ook de handelingsopties die gekozen worden om eraan tegemoet te komen.

Bij het identificeren van zorgbehoeften spelen ook opvattingen van het goede van betrokkenen een rol. Ze hebben invloed op wat wordt waargenomen en waarop wordt gereageerd. Volgens Sevenhuijsen moeten we daarom:

“... onze waarden als contingent zien. Het zijn waarden waarvan we de betekenis, de werking en de geldigheid steeds weer opnieuw moeten specificeren en beargumenteren, wetend dat we ze nooit volledig kunnen realiseren, en wetend dat er situaties zijn waarin we er grenzen aan willen stellen, of waarin we moeten concluderen dat het geen geschikte waarden zijn om de betreffende situatie mee te beoordelen." (p. 86).

Volgens zorgethici moeten betrokkenen bij morele kwesties steeds opnieuw stilstaan bij de vraag welke waarden binnen specifieke zorgpraktijken worden gehanteerd, of ze nog steeds van toepassing zijn en of ze ook in specifieke situaties nastrevenswaardig zijn. Door middel van communicatie, dialoog en reflectie moet de geldigheid van waarden voor specifieke situaties bediscussieerd worden.

Het systematisch nadenken over het concept 'zorg'in termen van 'praktijk' speelt zich met name af in feministische en algemeen zorgethische literatuur en krijgt minder aandacht binnen de verpleging. In verpleegkundige literatuur wordt door zorgethici verslag gedaan van kwalitatief empirische onderzoek naar opvattingen van goede zorg van verpleegkundigen. ${ }^{5}$ Er wordt praktijkonderzoek verricht om inzicht te krijgen in ideeën van verpleeg. kundigen over goede zorg, om van daaruit het denken en handelen van verpleegkundigen binnen specifieke zorgpraktijken te inspireren. De wijze waarop opvattingen van goede zorg binnen specifieke zorgpraktijken ontwikkeld worden - en omgekeerd - het denken en handelen van betrokkenen beïnvloeden, krijgt minder aandacht binnen de verpleging en wordt met name in feministische zorgethische literatuur uitgewerkt.

De resultaten van dit onderzoek ondersteunen het pleidooi van zorgethici om in het kader van verpleegkundige ethiek kwalitatief onderzoek te verrichten binnen de verpleging, om zicht te krijgen op opvattingen van verpleeg- 
kundigen over goede zorg, evenals de wijze waarop deze ontwikkeld worden en hun invloed op de zorgverlening. De manier waarop in zorgethische literatuur van buiten de verpleging zorg als praktijk is uitgewerkt, kan hiervoor als aanknopingspunt dienen.

\section{Morele zorgactiviteiten}

Zorgen heeft niet alleen een morele lading, omdat verpleegkundigen hun opvattingen van goede zorg daarbij inzetten. Zorg is ook moreel geladen omdat verpleegkundigen verzorgende handelingen uitvoeren met als doel de situatie voor patiënten draaglijker te maken én als ze bij het uitvoeren van verzorgende- en medisch-technische handelingen die nodig zijn in het kader van zorg en behandeling, rekening houden met gevoelens en emoties van patiënten.

In zorgethische literatuur van buiten de verpleging krijgt de concrete activiteit van het zorgen weinig aandacht. Zoals in hoofdstuk 2 aan de orde is gekomen, vatten zorgethici in navolging van Tronto (I993) 'zorgen' op als een proces waaraan vier fasen te onderscheiden zijn, namelijk: open staan voor zorgvragen, er de verantwoordelijkheid voor dragen, daadwerkelijk de zorgverlenen en reflecteren op de geboden zorg. Zorgethici hebben met name aandacht voor fase I, 2 en 4 en nauwelijks voor fase 3 , waarin de concrete activiteit van het zorgen centraal staat.

Ook in het kader van de zorgethiek binnen de verpleging, is weinig aandacht voor de concrete activiteit van het zorgen. Auteurs als Benner (I99I), Cooper (r99I), Parker (I990) en Salsberry (1992) doen weliswaar verslag van empirisch onderzoek naar de morele dimensie van verplegen. Daarbij gaat het er echter niet zo zeer om de morele lading van zorgactiviteiten te laten zien, maar om opvattingen van goede zorg die verpleegkundigen erop na houden inzichtelijk te maken. Het gaat er meer om te laten zien dat verpleegkundigen in de dagelijkse zorg morele kwesties tegenkomen die te maken hebben met de kwetsbaarheid en eindigheid van het menselijk bestaan en om te laten zien hoe ze daarmee omgaan, dan om zorgactiviteiten inzichtelijk te maken die een bijdragen leveren aan het draaglijker maken van het bestaan voor patiënten.

Uit het empirisch materiaal blijkt dat juist in de concrete activiteit van het zorgen het morele is vervat. Het signaleren van en tegemoet komen aan zorgbehoeften van patiënten om de situatie voor hen draaglijker te maken, speelt zich af binnen de handelingen die verpleegkundigen dagelijks verrichten. Het normatieve is ingebed in de activiteiten. In het kader van verpleegkundige ethiek is het daarom van belang ook fase 3 van het zorgproces verder uit te werken. Het onderscheid in typen morele activiteiten die in het denken en handelen van verpleegkundigen van afdeling to te onderscheiden zijn, kan 
daarbij bruikbaar zijn. Welke activiteiten zijn er binnen een specifieke zorgpraktijk expliciet op gericht het bestaan voor patiënten draaglijker te maken? Wanneer en op welke manier houden verpleegkundigen rekening met gevoelens, emoties en ervaringen van patiënten, bij het uitvoeren van activiteiten in het kader van zorg en behandeling? Bovendien is het van belang in het kader van verpleegkundige ethiek aandacht te hebben voor de vraag wanneer goede zorg samenhangt met aandacht voor essentiële zingevingsvraagstukken van patiënten en wanneer dat niet het geval is. Wanneer betekent goede zorg toch vooral aandacht hebben voor situaties die minder ingrijpend zijn in het leven van patiënten maar wel pijnlijk, lastig of frustrerend?

In deze paragraaf is beargumenteerd dat verplegen een morele lading heeft: op de eerste plaats omdat opvattingen van verpleegkundigen over goede zorg een rol spelen bij de zorg die ze geven; op de tweede plaats omdat het draaglijk maken van de situatie van patiënten zich veelal afspeelt binnen de dagelijkse en verzorgende handelingen zelf. Op basis van deze bevindingen is geconcludeerd dat verpleegkundige ethiek aandacht zou moeten hebben voor opvattingen van goede zorg en de morele lading van zorgactiviteiten. Niet alleen om vervolgens te bestuderen hoeveel ruimte verpleegkundigen krijgen de situatie voor patiënten zo draaglijk mogelijk te maken, ook omdat opvattingen van goede zorg en de morele lading van zorgactiviteiten binnen verpleegkundige ethiek verder kan worden uitgewerkt, aangescherpt of bekritiseerd.

In het kader van zorgethiek van buiten de verpleging wordt de invloed van opvattingen van goede zorg op het signaleren van en tegemoet komen aan zorgbehoeften gethematiseerd. Dit denken zou in het kader van verpleegkundige ethiek als aanknopingspunt gebruikt kunnen worden om dit thema verder uit te werken. Voor de morele lading van zorgactiviteiten is in zorgethische literatuur weinig aandacht, zowel binnen als buiten de verpleging. De derde fase van Tronto (1993) waarin de concrete activiteit van het zorgen centraal staat en 'competence' benoemt wordt als deugd van goede zorgverlening, zou in het kader van verpleegkundige ethiek verder uitgewerkt kunnen worden.

\section{ZORGRATIONALITEIT}

In deze paragraaf wordt een tweede kenmerk van zorg besproken dat uit dit onderzoek naar voren is gekomen. In de manier waarop verpleegkundigen van afdeling ro morele kwesties hanteren is een eigen werkwijze onderscheiden. Deze wordt in navolging van zorgethische auteurs 'zorgrationaliteit' genoemd. Dat wil niet zeggen dat het denken en handelen van verpleegkundi- 
gen samenvalt met opvattingen binnen zorgethiek over zorgrationaliteit. In het tweede deel van deze paragraaf wordt betoogd dat zowel verpleegkundigen van afdeling 1o, als zorgethici iets van elkaar kunnen leren.

Zorgen is doen, kennen, voelen, redeneren en overleggen

In deze paragraaf wordt beargumenteerd dat tegemoet komen aan zorgbehoeften van patiënten om de situatie draaglijker te maken een eigen rationaliteit heeft, waarin doen samengaat met kennen, voelen, redeneren en overleggen.

\section{Doen}

Door in dit onderzoek dagelijkse zorg centraal te stellen en door te bestuderen welke zorgbehoeften verpleegkundigen bij patiënten signaleren en hoe ze daarmee omgaan, zijn morele ervaringen van verpleegkundigen op een specifieke manier belicht. Er is onder andere zichtbaar gemaakt dat verpleegkundigen allerlei activiteiten verrichten in het kader van het zorgproces, die erop gericht zijn de situatie voor patiënten zo draaglijk mogelijk te maken. Vanuit deze bevinding wordt geconcludeerd dat ethiek binnen de verpleging te maken heeft met doen. Verpleegkundigen wassen patiënten om hen fysieke troost te geven. Verpleegkundigen schudden kussens op om patiënten comfort te bieden. Verpleegkundigen maken ruzie met artsen om deze ertoe te bewegen pijnmedicatie te verstrekken. Verpleegkundigen wijken van een protocol af wanneer ze ervan uitgaan dat dit de situatie voor patiënten onnodig ondraaglijk maakt. Verpleegkundigen slaan een arm om een patiënt heen om emotionele steun te bieden. Verpleegkundigen doen van alles om de situatie voor patiënten zo draaglijk mogelijk te maken.

De constatering dat verpleegkundigen van afdeling Io vooral 'doen' om de situatie voor patiënten draaglijker te maken, wil geenszins zeggen dat zorg louter een intuitieve of willekeurige aangelegenheid is. Het doen is ingebed in een structuur van kennen, voelen, redeneren en overleggen.

\section{Kennen, voelen, redeneren en overleggen}

In hoofdstuk 5 is het proces van zorgverlenen verder uitgediept door de onzekerheid te analyseren die verpleegkundigen ervaren. ${ }^{6}$ Hanteren van zorgbehoeften is onzeker omdat verpleegkundigen het gedrag en de vragen van patiënten moeten interpreteren. Het is niet altijd duidelijk wat nodig is om voor een patiënt het bestaan draaglijker te maken. Bovendien geven verpleegkundigen mede vorm aan het identificeren en formuleren van zorgbehoeften en vragen zich daarom af wat de betekenis van hun eigen invloed is." Zorg is ook onzeker omdat er verschillende inzichten kunnen bestaan over het draag- 
lijker maken van het bestaan van patiënten. Er is niet één antwoord mogelijk op de vraag 'hoe goed te doen?'. Tevens is zorg onzeker, omdat deze bijzonder veranderlijk. Niet alleen omdat ziekte en behandeling voortdurend veranderen, maar ook omdat patiënten en hun naasten hun situatie steeds weer anders kunnen ervaren. Omdat zorg inherent onzeker is, vragen verpleegkundigen zich in ieder patiëntencontact opnieuw af welke patiënt ze voor zich hebben en hoe voor hem of haar de situatie zo draaglijk mogelijk gemaakt kan worden.

De situatie voor patiënten draaglijker maken is in hoofdstuk 5 getypeerd als een proces dat zich kenmerkt door allerlei activiteiten die erop gericht zijn onzekerheid te voorkomen en hanteren.

Verpleegkundigen verzamelen verschillende soorten kennis en maken daar gebruik van, om zicht te krijgen op zorgbehoeften van patiënten. Verpleegkundigen van afdeling ro maken ten eerste gebruik van abstracte kennis. Deze wordt geleerd tijdens de opleiding en op de afdeling voortdurend aangevuld. De verpleegkundige van een Integraal Kankercentrum, ervaren verpleegkundigen of artsen geven informatie over ziektebeelden en behandeling aan andere verpleegkundigen. Verpleegkundigen maken gebruik van abstracte kennis om zorgbehoeften te signaleren. Door gebruik te maken van abstracte kennis weten verpleegkundigen waar ze op moeten letten. Ze weten wat ze kunnen verwachten, waardoor zorgbehoeften eerder worden gesignaleerd. Op de tweede plaats verzamelen verpleegkundigen individuele kennis van specifieke patiënten om begrip te krijgen voor hun fysieke, emotionele en sociale situatie en om een beeld te krijgen op hun persoonlijkheid. Verpleegkundigen creëren een totaalbeeld van een patiënt, om zicht te krijgen op zijn of haar zorgbehoeften. Om begrip te krijgen voor zorgbehoeften van patiënten is ook een vertrouwensrelatie nodig. Daarom investeren verpleegkundigen in het opbouwen en organiseren van een relatie met een patiënt. Daarnaast redeneren en overleggen verpleegkundigen met elkaar en andere zorgverleners om informatie uit te wisselen en elkaar aan te vullen om begrip te krijgen voor een patiënt, zodat een totaalbeeld gecreëerd kan worden van waaruit specifieke zorgbehoeften worden waargenomen. Verpleegkundigen stellen voor zichzelf en met anderen voortdurend de vraag hoe ze de situatie voor een patiënt draaglijker kunnen maken. Kennis en overleg helpen hen die vraag steeds opnieuw te beantwoorden.

Op basis van dit onderzoek kan geconcludeerd worden dat tegemoet komen aan zorgbehoeften van patiënten om de situatie draaglijker te maken van verpleegkundigen vraagt: dat ze allerlei activiteiten verrichten; dat ze daarbij gebruik maken van abstracte en individuele kennis; dat ze een vertrouwensrelatie met een patiënt aangaan en onderhouden; dat ze nadenken en redeneren over de vraag wat deze patiënt nodig heeft om de situatie als 
draaglijker te ervaren; en dat ze overleggen met collega verpleegkundigen en andere zorgverleners over de vraag wat goed is om te doen. Deze bevindingen maken duidelijk dat het hanteren van morele kwesties in de verpleging een eigen rationaliteit heeft, waarin doen, kennen, voelen, redeneren en overleggen met elkaar samengaan.

\section{Zorgrationaliteit binnen de verpleegkundige ethiek}

In de verpleegkundige principe-ethiek wordt het goed hanteren van morele kwesties in verband gebracht met een rationele werkwijze. Het gaat er om ethische principes op een objectieve en onpartijdige manier te wegen, zodat eigen belangen van betrokkenen of specifieke voorkeuren zo veel mogelijk worden buitengesloten van ethische beraadslaging. Zorgethici daarentegen propageren een relationele, betrokken en inlevende werkwijze voor het hanteren van morele kwesties. Om aan deze werkwijze evenveel gewicht te geven als aan de rationele methodiek van de principe-ethiek, noemen ze deze werkwijze 'zorgrationaliteit'.

Zorgethici' gebruiken de term 'zorgrationaliteit' om de eigen zorgethische logica van het goed hanteren van morele problematiek te benadrukken. Ze gebruiken de term 'rationaliteit' om te benadrukken dat het op een betrokken en verantwoordelijke wijze hanteren van morele kwesties, niet onderdoet voor de onpartijdige en objectieve werkwijze die de principe-ethiek voorstelt.

In de verdere uitwerking van de zorgrationaliteit in het kader van de zorgethiek is veel aandacht voor relationele vaardigheden die nodig zijn om het bestaan voor een ander draaglijker te maken. Deze worden gezien als belangrijke voorwaarden om daadwerkelijk te kunnen zien wat iemand nodig heeft om de draaglijkheid van het bestaan te vergroten. Daarom wordt de term 'epistemologische deugden' gebruikt. Met deze term wil men benadrukken dat relationele vaardigheden - kunnen communiceren, kunnen luisteren, meelevend zijn, betrokken kunnen raken - relevante kennis opleveren ow: de specifieke situatie en daarom voorwaarden zijn voor de zorgverlening. Vain zorgverleners wordt verwacht dat ze iets doen, namelijk actief betrokken raken bij de specifieke situatie van een ander en daadwerkelijk actie ondernemen om de situatie voor de ander draaglijker te maken.

Zorgrationaliteit wordt in feministische zorgethische literatuur in verband gebracht met praktische kennis." Deze term verwijst naar kennis van een persoon binnen een specifieke context en relaties. Dat wil zeggen de zorgvrager zien als specifiek persoon in zijn of haar specifieke omstandigheden. In zorgethische literatuur binnen de verpleging is ook aandacht voor theoretische kennis die nodig is om moreel verantwoord zorg te kunnen verlenen. Benner (1998) bespreekt de manier waarop praktische kennis en theoretische kennis 
in het dagelijks handelen versmelten tot bruikbare kennis. Beide vormen van kennis spelen volgens haar een belangrijke rol in verpleegkundige expertise. Praktische kennis is volgens haar nodig om theoretische kennis moreel te maken, in die zin dat de situatie aangeeft wanneer en hoe dergelijke kennis ingezet moet worden.

Zorgethici hechten veel waarde aan dialoog en reflectie bij het hanteren van morele problematiek. Door zorgethici als Sevenhuijsen (1996) of Widdershoven (1999a) en zorgethici uit de verpleging zoals Bellingen (2000) of Dierckx de Casterlé et. al. (2000) worden dialoog en reflectie als belangrijke voorwaarden voor zorgverlening gezien. Volgens hen zịnn dit belangriịke kenmerken van een zorgrationaliteit. Betrokkenen bij het hanteren van morele kwesties moeten zich volgens deze auteurs daarom steeds opnieuw afvragen hoe tegemoet gekomen kan worden aan zorgbehoeften van een zorgvrager om diens situatie draaglijker te maken. Er bestaat geen blauwdruk voor het hanteren van morele problematiek. Daarom moet er op het eigen en andermans handelen gereflecteerd worden. Zorgrationaliteit omvat naast denken, voelen, redeneren en overleggen ook de vaardigheden van dialoog en reflectie.

De bevinding in dit proefschrift dat het denken en handelen van verpleegkundigen zich kenmerkt door een eigen zorgrationaliteit, waarin doen, kennen, voelen, redeneren en overleggen met elkaar samengaan, sluit aan op zorgethische literatuur. Toch levert een vergelijking tussen theoretische discussies in de zorgethiek en de resultaten uit het empirische onderzoek wederzijdse leerpunten op.

Vanuit morele ervaringen van verpleegkundigen kan een bijdrage geleverd worden aan het denken over zorgrationaliteit. Zorgethici gaan ervan uit dat relationele vaardigheden een belangrijke rol spelen bij het zorgvuldig en verantwoordelijk hanteren van morele kwesties. De studie van het denken en handelen van verpleegkundigen van afdeling ro ondersteunt dit. Naast relationele vaardigheden gebruiken verpleegkundigen van afdeling ro echter ook niet-relationele vaardigheden om de situatie voor patiënten draaglijker te maken. Een relatie wordt niet alleen aangegaan, maar ook georganiseerd. De structuur en cultuur van een afdeling moet een relatie faciliteren. Verpleegkundigen moeten elkaar de ruimte geven om tijd te investeren in een relatie met een patiënt. De zorg op de afdeling moet bovendien zo verdeeld worden dat verpleegkundigen en patiënten daadwerkelijk in staat zijn elkaar beter te leren kennen. Overeenstemming over het belang van een relatie voor de zorg en het organiseren van een omgeving waarin een relatie tot stand kan komen, is net zo belangrijk als deugden die nodig zijn om een relatie aan te gaan en te onderhouden.

De verpleegkundigen van afdeling io zetten allerlei niet-relationele vaardigheden in om het bestaan van patiënten draaglijker te maken. Dat geldt niet 
alleen voor het organiseren van een relatie. Door het handelen van verpleegkundigen van afdeling ro te bestuderen is zichtbaar dat ze van alles doen om de situatie voor patiënten draaglijker te maken. Ze hangen foto's op om een kamer meer vertrouwd te maken, kijken met patiënten naar de t.v. om hen bezig te houden, schenden een protocol of gaan tegen opdrachten van artsen in wanneer ze ervan uitgaan dat een patiënt onnodig fysiek lijdt, ze lossen praktische problemen van familie op als een patiënt zich daar zorgen over maakt. Allerlei praktische, technische of assertieve vaardigheden worden ingezet om het bestaan voor patiënten zo draaglijk mogelijk te maken. Het handelen van verpleegkundigen van afdeling to kenmerkt zich door een grote variëteit aan vaardigheden en activiteiten. In het kader van een verpleegkundige ethiek gebaseerd op zorgethiek, zouden dergelijke vaardigheden en activiteiten verder overdacht en uitgewerkt moeten worden.

De zorgethiek kan niet alleen iets leren van de verpleegkundigen van afdeling 10. Ook het omgekeerde is het geval. In het kader van de zorgethiek wordt de nadruk gelegd op communicatie, reflectie en dialoog bij het hanteren van morele problematiek. Hoewel op afdeling Io regelmatig wordt overlegd om informatie en meningen uit te wisselen, is voor reflectie weinig ruimte. Tijdens overdrachten of koffiepauzes worden dergelijke onderwerpen soms aangesneden, maar niet systematisch doordacht. Verpleegkundigen van afdeling ro geven aan dat ze behoefte hebben aan intervisie en supervisie, maar krijgen dat door het management niet gehonoreerd.

Wanneer zorgethiek als moreel perspectief gebruikt wordt om het morele handelen van verpleegkundigen te ondersteunen, dan zou er meer ruimte gecreëerd moeten worden voor dialoog en reflectie. Reden daarvoor is dat verpleegkundigen dergelijke vaardigheden moeten aanleren en ontwikkelen om met elkaar over concrete morele kwesties van gedachten te kunnen wisselen. Zoals in de vorige paragraaf is beargumenteerd, wordt het handelen van verpleegkundigen beinvloed door opvattingen van goede zorg die ze hanteren. Hierdoor kunnen zorgbehoeften beter worden waargenomen. Ze kunnen het waarnemen en hanteren van zorgbehoeften ook belemmeren. Opvattingen van goede zorg vernauwen soms de blik. Ook daarom moet in de dagelijkse zorg aandacht zijn voor morele reflectie.

In het kader van zorgethiek is nog onvoldoende aandacht voor de vraag hoe voorkomen kan worden dat een bespreking over morele kwesties het niveau van gekibbel en gevoel overstijgt. In het kader van verpleegkundige ethiek zou aan dit onderwerp aandacht besteed moeten worden. Aanzetten daartoe zijn in de publicatie van Gastmans \& Casterlé (2000) terug te vinden. Deze kunnen gebruikt worden dit thema verder uit te werken. Bovendien wordt tegenwoordig in het kader van ethiek gesproken over moreel beraad, waarin handvatten worden aangereikt concrete morele kwesties op de werk- 
vloer te bespreken. ${ }^{.0}$ Ook deze literatuur kan gebruikt worden om in het kader van verpleegkundige ethiek het onderwerp van communicatie, reflectie en dialoog verder uit te werken.

In deze paragraaf is het onderwerp 'zorgrationaliteit' besproken. Betoogd is dat verpleegkundige ethiek aandacht moet hebben voor de manier waarop doen, kennen, voelen, redeneren en overleggen samengaan bij het hanteren van morele kwesties. Aanzetten hiervoor zijn te vinden in zorgethiek. Bovendien is in deze paragraaf betoogd dat theorie en praktijk iets van elkaar kunnen leren. Van de zorgethiek kunnen verpleegkundigen van afdeling ro én de organisatie waarin zij werkzaam zijn, leren dat verpleegkundige vaardig. heden zich moeten uitstrekken tot het domein van communicatie, dialoog en reflectie. In het dagelijks werk moet ruimte en tijd zijn om te kunnen reflecteren op het eigen handelen. Van verpleegkundigen kunnen zorgethici leren dat ook allerlei niet-relationele vaardigheden en activiteiten van belang zijn in het kader van het verlenen van goede zorg. Deze zouden in het kader van de zorgethiek verder uitgewerkt en doordacht moeten worden, om zicht te krij. gen op morele kwesties die samenhangen met zorgen.

\section{Betrokken heid}

Het belang van betrokkenheid voor de zorgverlening komt in de empirische hoofdstıkken tot uitdrukking. Betrokkenheid blijkt op verschillende manieren een rol te spelen bij het draaglijker maken van de situatie voor patiënten. Aan deze betrokkenheid zijn voor verpleegkundigen ook problemen verbonden. Om deze redenen kan 'betrokkenheid' gezien worden als centraal kenmerk van de zorg die verpleegkundigen van afdeling Io aan patiënten geven én tot relevant thema voor de verpleegkundige ethiek.

\section{Verschillende betekenissen van betrokkenheid}

In het denken en handelen van verpleegkundigen van afdeling Io zijn verschillende betekenissen van betrokkenheid te onderscheiden. Betrokkenheid wordt zichtbaar als antwoord op kwetsbaarheid, voorwaarde voor vertrouwen, voorwaarde voor kennis, als valkuil en als identiteit.

\section{Betrokkenheid als antwoord op kwetsbaarheid}

Betrokkenheid is in het denken en handelen van verpleegkundigen ten eerste zichtbaar als antwoord op kwetsbaarheid. In hoofdstuk 4 is besproken dat betrokkenheid bij patiënten volgens de verpleegkundigen van afdeling to nodig is omdat deze met een type problemen worden geconfronteerd dat 
daar om vraagt. Met patiënten praten over de betekenis van ziek-zijn of hoe het is om de dood in de ogen te zien, kan niet zonder als mens betrokken te zijn. Patiënten het gevoel geven dat ze gezien en gehoord worden en gerespecteerd worden als mens, vraagt om betrokkenheid van verpleegkundigen. Met patiënten meeleven, meedenken, een compagnon zijn vraagt om inlevingsvermogen, betrokkenheid en nabijheid. Patiënten die opgenomen zijn en behandeld worden voor een levensbedreigende ziekte, bevinden zich in een situatie waarin hun leven op zijn kop staat en alles onzeker is. Dat wat vanzelfsprekend was is dat niet langer. Patiënten zijn angstig en onzeker over het hier en nu en over de toekomst, voor zichzelf en voor hun naasten. Een dergelijke situatie waarin patiënten zich bevinden zo draaglijk mogelijk maken, vraagt van verpleegkundigen dat ze betrokken raken bij de patiënt die ze voor zich hebben.

\section{Betrokkenheid als voorwaarde voor vertrouwen}

In het denken en handelen van verpleegkundigen van afdeling Io is zichtbaar dat ze betrokkenheid in verband brengen met vertrouwen. Dat is zichtbaar geworden in hoofdstuk 4. Daar is aan de orde gekomen dat betrokkenheid nodig is om vertrouwen te creëren en patiënten het gevoel te geven dat ze in goede handen zijn. Patiënten hebben iemand nodig die hen ziet en de gehele situatie voor hen in de gaten houdt. Soms zijn patiënten om welke reden dan ook niet in staat eigen beslissingen te nemen of zelfs maar betrokken te zijn bij hun eigen situatie. Vooral dan is het van belang om erop te kunnen vertrouwen dat iemand dat van hen overneemt. De verpleegkundigen van afdeling ro zien dat als hun taak. Om dit vertrouwen te creëren is betrokkenheid nodig, zodat tot uitdrukking kan komen wat patiënten nodig hebben om de situatie als draaglijker te ervaren.

\section{Betrokkenheid als voorwaarde voor kennis}

In hoofdstuk 5 is betrokkenheid zichtbaar geworden als voorwaarde voor kennisverwerving. Dat is ook in de vorige paragraaf aangegeven, waarin onder de noemer 'zorgrationaliteit' is besproken hoe verpleegkundigen morele kwesties hanteren. Betrokkenheid bij patiënten is een voorwaarde om te kunnen zien wat nodig is om de situatie voor patiënten zo draaglijk mogelijk te maken, door begrip te krijgen voor hun vragen en behoeften. Betrokkenheid is niet alleen een manier van zijn en reageren, maar is ook een cognitieve aangelegenheid. Betrokkenheid is nodig om individuele kennis van de fysieke, emotionele en sociale situatie van de patiënt en diens persoon te verzamelen, om noden te zien, veranderingen te signaleren, zorgbehoeften te identificeren en er op te kunnen reageren. Omdat dit onderwerp in de vorige paragraaf aan de orde is gekomen, wordt er hier niet verder op ingegaan. 


\section{Betrokkenheid als valkuil}

In hoofdstuk 6 is aan de orde gekomen dat betrokkenheid zich aan verpleegkundigen opdringt door de situatie waarin ze zich met patiënten bevinden. Verpleegkundigen ontkomen er haast niet aan om betrokken te raken. Patiënten zijn vaak geruime tijd op de afdeling en maken daar een zeer ingrijpende periode door. Verpleegkundigen geven in die tijd intensieve en intieme zorg aan patiënten die soms doodziek, bang en ellendig in bed liggen. Verpleegkundigen maken verdrietige periodes mee, waarin patiënten onzeker zijn, met tegenslag of met een negatieve uitslag worden geconfronteerd. Verpleegkundigen maken ook mooie momenten met patiënten mee. Patiënten die dolblij zijn met een uitslag, of die een goed gesprek met familie hebben gehad, afscheid konden nemen of die de ziekte een plek hebben kunnen geven in hun bestaan.

Betrokkenheid is hierdoor ook een valkuil. In hoofdstuk 6 is zichtbaar gemaakt dat betrokkenheid om verschillende redenen tot problemen kan leiden. Op de eerste plaats omdat betrokkenheid bij patiënten tot een last voor verpleegkundigen kan worden. Bijvoorbeeld doordat verpleegkundigen zich de pijn en het lijden van patiënten te veel aantrekken of er zich te veel mee identificeren. Op de tweede plaats kan deze betrokkenheid problematisch zijn omdat verpleegkundigen gefrustreerd raken wanneer ze deze betrokkenheid niet waar kunnen maken. Zorg voor individuele patiënten vindt plaats binnen de context van de afdeling waar zorg verdeeld moet worden tussen patiënten en waar ook collega verpleegkundigen soms zorg nodig hebben. Door ervaringen van verpleegkundigen te bestuderen aan de hand van de vraag wanneer ze bemerken dat zorg voor individuele patiënten onder druk komt, kon op het spoor worden gekomen dat het draaglijker maken van het bestaan van patiënten ook te maken heeft met keuzes in de zorg. Zorg voor individuele patiënten wordt afgewogen tegen zorg voor zichzelf, andere patiënten en collega verpleegkundigen. Verpleegkundigen ervaren dergelijke keuzes in de zorg als frustrerend, wanneer ze concrete patiënten te kort moeten doen. De verpleegkundige-patiënt relatie leidt ertoe dat verpleegkundigen zich betrokken voelen bij patiënten en de verantwoordelijkheid op zich nemen voor hen te zorgen. De context van de afdeling maakt het soms moeilijk aan deze verantwoordelijkheid gestalte te geven, omdat er keuzes moeten worden gemaakt.

\section{Betrokkenheid als identiteit}

Betrokkenheid heeft in het denken en handelen van verpleegkundigen ook te maken met hun eigen identiteit. Wanneer verpleegkundigen niet meer bij patiënten betrokken kunnen raken en voor hen kunnen zorgen op eex manier die zij goed vinden, komt hun eigen identiteit in het gedrang en ook 
de betekenis die zorgen voor hun eigen leven heeft. In hoofdstuk 6 is aan de orde gekomen dat verpleegkundigen vaak voor het vak kiezen, omdat ze betrokken willen raken bij patiënten en iets voor hen willen betekenen. Ze vinden zorg voor anderen een waardevolle ervaring. Zorgen voor een ander staat niet los van de identiteit van henzelf en de zin en betekenis die deze activiteit in het kader van hun persoonlijke leven heeft. Verpleegkundigen ervaren de tijd die ze krijgen om voor patiënten te zorgen regelmatig als te beperkt." Ze kunnen dan niet die zorg geven die ze zouden willen geven. Ze herkennen zich daardoor soms zelf niet meer in de persoon die ze zijn geworden: de persoon die alleen maar rondrent en zorg biedt die een dwingend karakter heeft (vaak de medisch-technische zorg en lichamelijke verzorging), maar geen tijd heeft daarbij activiteiten te verrichten om de situatie voor patiënten draaglijker te maken of de medische-technische en verzorgende handelingen uit te voeren met voldoende aandacht voor gevoelens, emoties en ervaringen van patiënten. Verpleegkundigen hebben het gevoel dat ze niet alleen patiënten, maar ook zichzelf verloochenen wanneer ze niet die zorg geven die ze zelf goed vinden.

\section{Betrokkenheid binnen de verpleegkundige ethiek}

In de zorgethiek wordt betrokkenheid centraal gesteld. De onderwerpen rondom betrokkenheid die in het denken en handelen van verpleegkundigen zijn onderscheiden, kunnen in het kader van deze ethiek dan ook verder overdacht en uitgewerkt worden. In deze paragraaf wordt het thema 'betrokkenheid' besproken in het licht van zorgethiek. Hierbij wordt onderscheid gemaakt tussen literatuur van buiten en binnen de verpleging, wanneer er verschillen zijn.

\section{Betrokkenheid als antwoord op kwetsbaarheid}

Betrokkenheid als 'antwoord op kwetsbaarheid' speelt een belangrijke rol in het denken van zorgethici, met name van buiten de verpleging.

Zorgethici brengen het thema van 'betrokkenheid' in verband met een bepaald mensbeeld en hun opvattingen over autonomie. Volgens zorgethici staat in de principe-ethiek het mensbeeld centraal waarin een individu wordt gezien als een autonoom wezen. Onafhankelijkheid is het ideaal voor mens-zijn. Zorgethici van buiten de verpleging verzetten zich tegen een dergelijk beeld van het individu. Wanneer dit liberale mensbeeld namelijk uitgangspunt is van ons denken, dan gaat het vervolgens vooral om de vraag hoe onafhankelijkheid kan worden bewaard. Over ethische problematiek wordt gesproken in termen van rechten en bevoegdheden, om te garanderen dat mensen in vrijheid kunnen leven. 
Zorgethici nemen een ander mensbeeld als uitgangspunt van het denken. Mensen zijn volgens hen altijd in meerdere of mindere mate afhankelijk van anderen om vorm te geven aan het eigen leven, omdat het leven eindig en kwetsbaar is. Mensen hebben zorg van anderen nodig om hun eigen leven te leven. In de ethiek moet het daarom gaan om de vraag welke zorg specifieke mensen nodig hebben om het bestaan zo draaglijk mogelijk te maken. Het gaat om het draaglijk maken van een kwetsbaar en eindig bestaan, dat zich afspeelt in termen van afhankelijkheid. In zorgethiek staat de vraag centraal: hoe kunnen relaties met anderen - die zich kenmerken door verantwoordelijkheid en betrokkenheid - ertoe bijdragen dat de draaglijkheid van een kwetsbaar en eindig bestaan wordt bevorderd?

Zorgethici ${ }^{12}$ stellen dat wanneer een mensbeeld van onafhankelijkheid het uitgangspunt is, veel mensen in onze samenleving (en dat is zeker in de gezondheidszorg het geval) zich in een situatie bevinden waarin nooit te winnen valt omdat het ideaalbeeld van onafhankelijkheid veel te hoog gegrepen is. Mensen zullen altijd zorg van anderen nodig hebben om hun wereld zo leefbaar mogelijk te maken. Het is daarom zinvoller te denken over de vraag welke zorg mensen nodig hebben om het kwetsbare bestaan zo leefbaar mogelijk te maken, dan dat we ons afvragen hoe onafhankelijkheid zo veel mogelijk kan worden gegarandeerd. Niet de vraag hoe zelfbeschikkingsrecht kan worden gegarandeerd moet uitgangspunt zijn van ons denken, maar de vraag hoe kwetsbaarheid kan worden gehanteerd, zodat iemand een leven kan leiden dat bij hem of haar past. Een dergelijke opvatting wordt in het kader van zorgethiek buiten de verpleging besproken in termen van relationele autonomie als authenticiteit (zie hoofdstuk 2). Autonoom zijn heeft dan niet de betekenis van zelfbeschikking. Autonomie heeft te maken met het hanteren van de kwetsbaarheid van het bestaan door groei, zelfontplooiing, zelfverwerkelijking, zelfrespect en zelfvertrouwen, omdat hierin de leefbaarheid van de wereld tot uitdrukking komt.

Het thema van 'betrokkenheid' krijgt ook aandacht binnen verpleegkundige zorgethische literatuur. Dit onderwerp wordt daarbij niet zo zeer in verband gebracht met verschillende mensbeelden die daaraan ten grondslag kunnen liggen of opvattingen van autonomie. ${ }^{13}$ Betrokkenheid als antwoord op kwetsbaarheid wordt in verband gebracht met relaties. Een relatie met een patiënt is nodig om tegemoet te kunnen komen aan vragen die samenhangen met de kwetsbaarheid van het bestaan. Om noden van patiënten te kunnen verlichten is het nodig dat verpleegkundigen een relatie met deze patiënten aangaan.

Zoals eerder in dit hoofdstuk is belicht, richten de verpleegkundigen van afdeling to zich niet zo zeer op vragen, die onder de noemer van relationele autonomie als authenticiteit worden besproken. Verpleegkundigen gaan wel 
in op behoeften van patiënten die samenhangen met zelfrespect of zelfvertrouwen. Doel daarvan is niet patiënten actief te stimuleren op zoek te gaan naar de zin van het bestaan of de eigen identiteit. De verpleegkundigen van afdeling ro hebben aandacht voor zelfrespect en zelfvertrouwen, omdat deze van belang zijn voor het draaglijker maken van de situatie voor patiënten. Ze stimuleren zelfvertrouwen om bijvoorbeeld angst en onzekerheid van patiënten te verminderen. Om die reden geven ze soms ook positieve feedback of confronteren ze patiënten met de manier waarop ze met hun situatie omgaan. Patiënten stimuleren om zich te ontwikkelen is daarbij niet het uitgangspunt van de zorg. Het gaat erom ervoor te zorgen dat patiënten zo goed mogelijk door het ziek zijn, behandeld worden en opgenomen zijn heen komen.

De manier waarop betrokkenheid als antwoord op kwetsbaarheid een rol speelt bij het draaglijker maken van de situatie voor patiënten, zou binnen de verpleegkundige ethiek verder bestudeerd moeten worden, omdat dit een belangrijke rol speelt in de ervaringen van verpleegkundigen op de werkvloer. Hoewel opvattingen van zorgethici over relationele autonomie als authenticiteit daarbij betrokken kunnen worden, is het toch de vraag tot hoever de verantwoordelijkheid van verpleegkundigen daarbij strekt. Het antwoord op deze vraag zal wellicht contextueel zijn. In sommige contexten zou goede zorg gericht kunnen zijn op het ontwikkelen van de identiteit en persoonlijkheid van patiënten. In andere contexten kan dit worden opgevat als ongewenste bemoeienis. ${ }^{4}$ Verpleegkundige ethiek zou dergelijke vragen, in samenhang met betrokkenen uit concrete praktijken, moeten overdenken. In welke context is het van belang patiënten te stimuleren na te denken over wie ze zijn en hoe ze invulling geven aan het eigen leven? Welke kennis en vaardigheden hebben verpleegkundigen nodig, wanneer ze een dergelijke rol moeten vervullen? In welke contexten verwordt zorg tot ongewenste bemoeienis, wanneer verpleegkundigen patiënten actief stimuleren na te denken over hun eigen persoonlijkheid en de zin van het eigen leven?

\section{Betrokkenheid als voorwaarde voor vertrouwen}

'Vertrouwen' wordt met name in het kader van de zorgethiek buiten de verpleging gethematiseerd. Vertrouwen is volgens zorgethici nodig om iets dat voor mensen van belang is (zoals bijvoorbeeld hun gezondheid) over te kunnen dragen aan de zorgen van een ander. Vertrouwen wordt binnen zorgethiek op twee manieren beschouwd als voorwaarde voor zorg. Op de eerste plaats heeft de zorgontvanger vertrouwen nodig om het gevoel te hebben dat hij of zij in goede handen is en dat er zorgvuldig voor hem of haar wordt gezorgd. Om dat vertrouwen te creëren moet de zorgverlener laten zien dat zij betrokken en deskundig is en de bereidheid heeft de nodige tijd en ener- 
gie in zorg te steken. Vertrouwen is op de tweede plaats nodig om te weten hoe je voor een ander kan zorgen op een manier die bij de ander past. Vertrouwen in elkaar is nodig. on begrip te krijgen voor de specifieke ander en diens wensen en verwachtingen. Vertrouwen is nodig om voor iemand te kunnen zorgen op een manier die de situatie voor de ander zo draaglijk mogelijk maitkt. De zorgverlener kan pas zorgvuldig omgaan met datgene wat aan zijn zorgen wordt toevertrouwd, wanneer hij weet wat het voor de ander betekent zichzelf (of iets dat voor hem of haar van waarde is) aan de zorgen van iemand anders toe te vertrouwen.

In zorgethische literatuur binnen de verpleging wordt het concept 'vertrouwen' vooral in verband gebracht met het kunnen aangaan en onderhouden van een relatie. De manier waarop dit concept in zorgethische literatuur van buiten de verpleging wordt geanalyseerd en aangescherpt, zou als aanknopingspunt kumnen dienen om dit concept voor de verpleging verder uit te diepen en uit te werken. Zoals in het eerste deel van deze paragraaf is belicht gaat het op afdeling ro ook om de vraag hoe deskundigheid, tijd en aandacht een rol spelen bij het zorgen voor patiënten. Verpleegkundige ethiek zou dit onderwerp verder moeten uitwerken. Hoe kunnen verpleegkundigen, wanneer patiënten dat zelf niet meer kunnen, voor hen zorgen op een manier die bij hen past? Hoe kunnen patiënten erop vertrouwen dat, wanneer ze dat zelf nict meer in de gaten kunnen houden, er toch voor hen gezorgd wordt op een manier waaruit blijkt dat ze ertoe doen? Kunnen verpleegkundigen vertrouwerl creëren door te laten zien dat ze deskundig zijn, aandacht hebben en bereid zijn de nodige tijd en energie aan de patiënt te besteden?

\section{Betrokkenheid als valkuil}

In de zorgethiek worden de valkuilen van betrokkenheid erkend. Zowel in literatuur van buiten als van binnen de verpleging is hiervoor aandacht. Zorg voor een ander vraagt om betrokkenheid. Hierin schuilt volgens Verkerk (r998) ook de tragiek van de zorg waar veel zorgverleners tegenaan lopen. Soms staan ze machteloos in hun zorgen. Ze kumnen niet voor iedereen zorgen. Zorg is altijd het resultaat van een keuze. Vooral wanneer zorgverleners keuzes krijgen opgedrongen (bijvoorbeeld door de institutionele context waarin wordt gezorgd) kan dat ertoe leiden dat zorgverleners gevoelsmatig in de problemen komen. In zorgethiek wordt zorg ook in verband gebracht met zelfzorg en opoffering. Omdat zorg vraagt om betrokkenheid, vraagt dit van de zorgverlener dat deze ook voor zichzelf zorgt. Zorgen voor een ander kan niet zonder rekening te houden met de eigen behoeften. Wanneer een zorgverlener dat niet doet kan zorg leiden tot zelfopoffering."

De verantwoordelijkheid om de valkuilen van betrokkenheid te omzeilen worden in de zorgethiek niet alleen op de schouders van zorgverleners ge- 
legd. ${ }^{7}$ Hoewel zorgverleners een eigen verantwoordelijkheid hebben in het aangeven van grenzen of - meer zorgethisch geformuleerd - ook hun eigen behoeften aan zorg naar voren zouden moeten brengen, wordt daarnaast gepleit om aandacht te besteden aan de institutionele en maatschappelijke context waarin wordt gezorgd. Door deze context te benadrúkken waardoor de lasten van het zorgen voor een ander ontstaan of worden versterkt, kan aandacht komen voor de vraag welke zorg zorgverleners zelf nodig hebben om op de langere termijn zorg te kunnen blijven verlenen.

Vanuit dit onderzoek kan dit pleidooi worden onderschreven. In hoofdstuk 6 is aan de orde gekomen dat de context van de afdeling voor verpleegkundigen tot frustraties kan leiden omdat ze niet díe zorg kunnen geven die ze zouden willen geven. Vooral betrokkenheid bij de situatie van patiënten komt onder spanning te staan, wanneer er onvoldoende tijd is om aan de zorgbehoeften van alle patiënten aandacht te besteden. In het kader van verpleegkundige ethiek zou aandacht moeten zijn voor vragen als: welke contexten ondersteunen de zorg die zorgverleners geven en welke contexten kunnen belemmerend werken? Dergelijke vragen zijn niet alleen zinvol in het kader van het bevorderen van de kwaliteit van leven van patiënten maar ook voor de kwaliteit van werken van verpleegkundigen.

In hoofdstuk 6 is besproken dat betrokkenheid bij patiënten voor verpleegkundigen ertoe kan leiden dat het zorgen voor een ander te veel wordt. Bijvoorbeeld omdat ze zich het leed van patiënten te veel aantrekken of omdat ze zich met hen gaan identificeren. Deze lasten van het zorgen worden in het: kader van zorgethiek overdacht. Deze literatuur is bruikbaar om dit thema in het kader van verpleegkundige ethiek verder te overdenken. Ethiek moet zich ook bezig houden met de vraag wat verpleegkundigen zelf nodig hebben, zowel als persoon als ook uit de context waarin ze zich bevinden, om de situatie voor patiënten zo draaglijk mogelijk te maken.

\section{Betrokkenheid als identiteit}

De zorgethiek bespreekt betrokkenheid ook in termen van 'identiteit' vanuit de opvatting, dat betrokken zijn in een zorgrelatie vormend is voor de identiteit van de zorgverlener. Hoe kan betrokkenheid bij een ander van warde zijn voor het zinervarend bestaan en daarmee een bijdrage leveren aan de eigen identiteit? ${ }^{18}$ Voor een ander zorgen kan het gevoel van eigenwaarde, het zelfrespect en zelfvertrouwen versterken. Zorgverleners kunnen hun identiteit ontlenen aan de zorg die ze geven. Zorgethici overdenken zorg als waardevolle en zingevende activiteit, om daarmee de positie van vrouwen (die vooral zorgen) en de status van zorgende activiteiten (maatschappelijk nog vaak laag) te verhogen. Door zorgethici binnen de verpleging wordt daarnaast aangegeven dat hoewel het voor de zorgverlener weliswaar zinvol kan zijn 
voor een ander te zorgen, de zorgbehoeften van zorgvragers op de eerste plaats moeten komen. Het kan niet zo zijn dat verpleegkundigen hun eigen behoeften als uitgangspunt nemen. Dat zorgen voor een ander een zinvolle en waardevolle activiteit is, die ook voor de zorgverlener van belang is, mag er niet toe leiden dat de zorgvrager niet meer die zorg krijgt die deze nodig heeft.

Zoals in hoofdstuk 6 is aangegeven, kiezen verpleegkundigen vaak voor het vak omdat ze het zorgen voor een ander als waardevol ervaren. Het geeft zin aan hun eigen leven. Wanneer zorg onder druk komt is daarom niet alleen de kwaliteit van zorg voor patiënten in het geding, maar dreigt ook het gevoel bij verpleegkundigen dat ze zichzelf verloochenen. De verpleegkundige die ze zijn geworden, valt niet meer samen met de persoon die ze willen zijn. Verpleegkundige ethiek zou daarom aandacht moeten besteden aan de vraag hoe de (institutionele) context van de zorg ertoe kan leiden dat de eigen identiteit van verpleegkundigen onder druk komt omdat ze niet die zorg kunnen geven die ze willen geven.

In deze paragraaf zijn de verschillende betekenissen van betrokkenheid beschreven zoals die op afdeling ro tot uitdrukking kwamen. Binnen de verpleegkundige ethiek dienen deze vormen van betrokkenheid verder gethematiseerd te worden. Een aantal betekenissen van betrokkenheid worden met name in zorgethische literatuur buiten de verpleging besproken. Deze literatuur kan gebruikt worden om dit onderwerp binnen de verpleging verder te verdiepen. Welke betekenissen van betrokkenheid zijn in verschillende contexten te onderscheiden? Wanneer en in welke context leidt betrokkenheid tot problemen voor verpleegkundigen zelf? Op welke manieren kan betrokkenheid van verpleegkundigen bij patiënten worden ondersteund of gefaciliteerd? Wat zegt betrokkenheid bij patiënten over de identiteit van verpleegkundigen en de zin en betekenis die dit kan geven aan hun werk? Met andere woorden: wat levert zorgen voor verpleegkundigen zelf op en hoe verhoudt zich dat tot de verantwoordelijkheid te zorgen voor een ander? Ook kan de vraag bestudeerd worden wanneer (goed bedoelde) betrokkenheid verwordt tot onacceptabele betutteling van patiënten. Dit aspect van betrokkenheid wordt in de volgende paragraaf besproken, waarin onder andere de grenzen aan bemoeienis met het leven van patiënten worden onderzocht.

\section{IN DISCUSSIE MET PATIENTEN OVER DE INHOUD VAN ZORG}

Uit het empirische onderzoek bleek dat er op de werkvloer regelmatig wordt gediscussieerd over de inhoud van de zorg. Niet alleen tussen verpleegkundigen onderling of met andere zorgverleners, maar ook met patiënten. 'Discus- 
sie over de inhoud van zorg' is naar aanleiding hiervan als kenmerk van morele ervaringen van verpleegkundigen van afdeling ro benoend. Verpleegkundigen worden regelmatig geconfronteerd met vragen van patiënten waaraan ze eigenlijk niet tegemoet willen komen, omdat ze ervan uitgaan dat het beantwoorden ervan de situatie voor patiënten niet draaglijker zal maken. In deze paragraaf wordt ingegaan op de manier waarop verpleegkundigen van afdeling ro omgaan met dergelijke situaties. Daarbij komt ook aan de orde hoe ver verpleegkundigen denken dat ze mogen gaan in hun bemoeienis met het leven van patiënten. In het tweede deel van deze paragraaf wordt ingegaan op de vraag of en hoe dergelijke kwesties zich verhouden tot theorievorming in de zorgethiek.

\section{Zoeken naar een gezamenlijk gedragen zorgproces}

De verpleegkundigen van afdeling Io worden geconfronteerd met patiënten die iets van hen vragen, terwijl zij denken dat dit de situatie voor patiënten minder draaglijk zal maken. In hoofdstuk 6 is aan de orde gekomen dat het tijdsaspect daarbij een rol speelt. Gaat het om het hier en nu? Of gaat het om de toekomst? Patiënten hebben soms het hier en nu voor ogen, omdat de situatie waarin ze zich bevinden zo pregnant ondraaglijk voor hen is. Vanuit deze ervaring formuleren zij hun behoeften aan zorg. Verpleegkundigen hebben daar aandacht en begrip voor en stemmen er hun handelen op af. Tegelijkertijd houden ze de langere termijn in de gaten. Het gaat er volgens hen niet alleen om de situatie voor patiënten op dit moment zo draaglijk mogelijk te maken, maar daarbij ook de gevolgen voor de toekomst in de gaten te houden. Dit kan leiden tot discussie met patiënten. Een patiënt vraagt om met rust gelaten te worden. Hij wil niet eten, niet drinken, zijn bed niet uit of geen medicatie, terwijl verpleegkundigen denken dat dit wel nodig is om hun bestaan ook in de toekomst draaglijk te houden. Patiënten die niet drinken drogen uit. Patiënten die niet uit bed komen krijgen decubitus. Wanneer dat gebeurt is de draaglijkheid van het bestaan in het geding. Verpleegkundigen hanteren dergelijke situaties door te zoeken naar een situatie waarin beide zich kunnen vinden, zodat het zorgproces door beide wordt gedragen.

\section{Zoeken naar overeenstemming}

Wanneer er verschil van mening is met patiënten over 'hoe goed te doen', verrichten verpleegkundigen verschillende activiteiten om hier een uitweg uit te vinden. Deze activiteiten zijn erop gericht ruimte te geven aan patiënten om hun behoeften aan zorg te uiten en tegelijkertijd de eigen opvattingen over 'hoe goed te doen' hierin mee te nemen. ${ }^{20}$ Het handelen van verpleegkundigen is erop gericht van elkaar te leren en naar elkaar toe te groeien. 
In hoofdstuk 6 is aangegeven hoe verpleegkundigen proberen met patiënten tot overeenstemming te komen in situaties waarin er meningsverschillen zijn over de inhoud van de zorg. Ze proberen op de eerste plaats wederzijds begrip te creëren ( $\mathrm{ik}$ begrijp wat $\mathrm{u}$ bedoelt, maar begrijpt $\mathrm{u}$ ook mijn standpunt?). Ze leggen daarbij hun eigen standpunt uit door informatie te verstrekken en de consequenties te benadrukken (door lang achter elkaar in bed te liggen, kan decubitus of trombose ontstaan). Daarnaast proberen ze zicht te krijgen op behoeften van patiënten en begrip te ontwikkelen voor hun vragen (waarom is het voor $u$ zo moeilijk uit bed te komen?). Soms veranderen ze zelf van mening ( $\mathrm{ik}$ snap wat $\mathrm{u}$ bedoelt, $\mathrm{u}$ heeft gelijk). Een andere manier om met patiënten tot overeenstemming te komen is door hen te motiveren of hen te overtuigen van hun opvattingen over goede zorg. Bijvoorbeeld door patiënten te herinneren aan het doel dat ze voor ogen hadden ( $u$ wilde toch weer gezond worden?), aanlokkelijke omstandigheden te creëren (wilt u niet gezellig samen met mevrouw $x$ aan tafel eten?), alternatieven te bieden ( $u$ wilt geen boterham eten? wat vindt $u$ van pap?), of patiënten te verleiden tot bepaald gedrag (op een creatieve manier een mooie sjaal om het hoofd binden). Volgens verpleegkundigen hebben patiënten soms een duwtje in de rug nodig, om zich ertoe te zetten ook toekomstige situaties bij hun overwegingen in het hier en nu te betrekken. Vaak leiden dergelijke processen ertoe dat uiteindelijk een middenweg wordt bewandeld (niet een half uur uit bed en ook niet helemaal niet, maar een kwartier).

Bij het zoeken naar overeenstemming met patiënten in situaties dat er discussie is, hebben zowel patiënten als verpleegkundigen een eigen inbreng. Patiënten geven aan wat ze graag zouden willen en er wordt geluisterd naar hun emoties, gevoelens en ervaringen. Verpleegkundigen geven aan hoe zij denken dat de situatie voor dat moment draaglijker kan worden en ook in de toekomst draaglijk zal blijven. Het handelen van verpleegkundigen is erop gericht om een invulling aan het zorgproces te geven waarin beiden zich kunnen vinden.

\section{Communicatie openhouden}

Het denken en handelen van de verpleegkundigen van afdeling Io kenmerkt zich door een streven de communicatie met patiënten open te houden en conflicten te voorkomen. In hoofdstuk 6 is aan de orde gekomen dat verpleegkundigen tijdens dit proces waarin gezocht wordt naar overeenstemming proberen conflicten te vermijden. Ze gaan ervan uit dat de mogelijkheid tot zorgen wordt belemmerd, wanneer ze lijnrecht tegenover patiënten komen te staan. Fen open communicatie is nodig om begrip te krijgen voor patiënten en zicht te krijgen op hun gevoelens, emoties en ervaringen, als ook om van gedachten te kunnen veranderen en de eigen mening te herzien, om weder- 
zijds begrip te creëren, toekomstige opties open te houden en te zoeken naar een middenweg. Een open communicatie is nodig om het proces zo vorm te geven dat het door beide gedragen kan worden. Wanneer er een meningsverschil is, zorgen verpleegkundigen er daarom voor dat ze met patiënten in gesprek blijven. Ze waken ervoor dat een situatie ontstaat waarin ze lijnrecht tegenover elkaar komen.

\section{Grenzen aan bemoeienis}

Verpleegkundigen bemoeien zich met het leven van hun patiënten. Meestal vragen ze zich daarbij niet af hoe ver ze daarin mogen gaan. Zoals in het bovenstaande is beschreven, zoeken ze in het zorgproces zo veel mogelijk naar overeenstemming, omdat ze ervan uitgaan dat vooral in een gezamenlijk gedragen zorgproces de situatie voor patiënten draaglijker zal worden. Patiënten motiveren, overtuigen en overhalen beschouwen ze daarbij als vanzelfsprekend onderdeel van dat proces. Patiënten hebben volgens verpleegkundigen soms dat duwtje in de rug nodig, juist omdat ze hun situatie op een bepaald moment zo pregnant als ondraaglijker ervaren.

Er zijn echter situaties waarin verpleegkundigen zich wél afvragen hoe ver ze mogen gaan in hun beinvloeding van patiënten. Mag je blijven 'trekken' aan mensen, om te achterhalen waar ze mee bezig zijn of welke vragen en problemen zij ondervinden? Verpleegkundigen vragen zich ook af in hoeverre ze zich mogen bemoeien met relaties die mensen met elkaar hebben, zoals de moeder-dochter relatie die in hoofdstuk 5 is besproken of de relatie die een jongen van 44 met zijn ouders had. De discussie spitst zich dan toe op de vraag onder welke omstandigheden deze invloed toegestaan is. Uiteindelijk, zo is in het denken van verpleegkundigen zichtbaar, is dat alleen het geval wanneer ze ervan uitgaan dat het leven voor de patiënt in verregaande mate ondraaglijk is of dat zal worden wanneer zij zich er niet mee bemoeien. Bijvoorbeeld als ze denken dat een patiënt erg angstig en onzeker is, maar daar niet over kan praten terwijl hem dat wel zou opluchten. Of wanneer verpleegkundigen denken dat een patiënt veel behoefte heeft aan een andere relatie met familie, maar zelf niet in staat is daar iets aan te veranderen. Wanneer dergelijke situaties aan de orde zijn, is echter moeilijk te bepalen. Zoals in hoofdstuk 5 is beschreven zeggen patiënten niet altijd luid en duidelijk waar ze behoeften aan hebben of zeggen ze ook wel eens iets anders, bijvoorbeeld juist omdat ze bang zijn emoties te tonen. Situaties waarin de vraag aan de orde is waar grenzen liggen aan bemoeienis, zijn daarom ook onderwerp van gesprek tussen verpleegkundigen onderling tijdens overdrachten en koffiepauzes. 


\section{Rigoureus toedelen van verantwoordelijkheid als noodgreep}

Uiteindelijk blijven er toch situaties over, waarin het niet lukt om met: patiënten tot overeenstemming te komen. Patiënten blijven zich verzetten tegen bemoeienis van verpleegkundigen met hun leven. Verpleegkundigen van afdeling Io gaan in dergelijke situaties over tot het rigoureus toedelen van verantwoordelijkheden. Soms trekken ze de beslissing over de inhoud van het zorgproces volledig naar zich toe en verwijzen daarbij naar hun eigen professionele verantwoordelijkheid. Soms krijgen patiënten de gehele verantwoordelijkheid toebedeeld, om over de inhoud van het zorgproces te: beslissen. Zoals in hoofdstuk 6 is besproken hangt de keuze om de verantwoordelijkheid op een bepaalt moment rigoureus te verdelen voor verpleegkundigen af van de ernst van de schade die een patiënt oploopt als gevolg van hun eigen beslissing, van de vraag of ze denken dat een patiënt voldoende zicht heeft op de eigen situatie en of deze de consequenties van bepaalde keuzes kan overzien.

In de relatie tussen verpleegkundige en patiënt spelen verantwoordelijkheden altijd een rol. Verpleegkundigen en patiënten hebben als het ware de gedeelde verantwoordelijkheid een situatie te vinden, waarin beiden zich kunnen vinden. Wanneer de situatie uit de hand loopt en er een conflict ontstaat, trekken verpleegkundigen de keuze naar zich toe om de verantwoordelijkheden rigoureus te verdelen. Ze proberen dergelijke situaties zo veel mogelijk te voorkomen, omdat ze ervan uitgaan dat in een dergelijke situatie het meningsverschil over de invulling van het zorgproces blijft voortbestaan, waardoor het streven om de situatie voor patiënten draaglijker te maken wordt ondermijnd. Wanneer dergelijke situaties zich voordoen, is het handelen van verpleegkundigen er daarom onverminderd op gericht om een invulling van het zorgproces te vinden dat door beiden wordt gedragen.

In het eerste deel van deze paragraaf is beschreven hoe verpleegkundigen in discussie gaan met patiënten wanneer deze iets van hen vragen dat volgens verpleegkundigen het bestaan uiteindelijk niet draaglijker zal maken. Ze zoeken daarbij naar een gezamenlijke invulling van het zorgproces. Verpleegkundigen streven ernaar zorg te geven waarnaar patiënten vragen, waarbij ze tegelijkertijd hun eigen opvattingen van goede zorg meenemen. Om ruimte te bieden voor inbreng van beide, wordt gezocht naar overeenstemming. Daarbij wordt getracht conflicten zo veel mogelijk te voorkomen, vanuit de veronderstelling dat dit het zorgproces zal ondermijnen. Soms lukt dat echter niet en komen ze lijnrecht tegenover de patiënt te staan. Dan vindt het zorgproces voortgang doordat verpleegkundigen één van beide de volledige verantwoordelijkheid toebedelen, zichzelf of patiënten. Vervolgens blijft het handelen er op gericht opnieuw een invulling aan het zorgproces te geven dat door beiden wordt gedragen. 


\section{Omgaan met meningsverschillen binnen de verpleegkundige ethiek}

De verpleegkundigen van afdeling Io worden regelmatig geconfronteerd met vragen van patiënten, waaraan ze niet zonder meer tegemoet willen komen, omdat ze ervan uitgaan dat het beantwoorden er van de situatie voor patiënten uiteindelijk niet draaglijker zal maken. Goede zorg geven aan patiënten betekent voor verpleegkundigen van afdeling ro niet, dat ze zonder meer doen wat een patiënt van hen vraagt. Kenmerk van de morele ervaringen van verpleegkundigen is dat ze discussies aangaan met patiënten over de inhoud van het zorgproces In het tweede deel van deze paragraaf wordt besproken hoe deze thema's spelen in de verpleegkundige ethiek.

\section{Meningsverschillen in zorgethisch perspectief}

De opdracht voor zorgverleners is volgens zorgethici niet om 'zelfbeschikkingrecht van patiënten te beschermen', maar om zich op betrokken en verantwoordelijke wijze te bemoeien met hun leven. Verkerk (r999, 2001) spreekt over 'compassionate interference'. Bemoeienis met het leven van anderen, zelfs als een ander daar op een bepaald moment niet van gediend is, wordt in een zorgethisch perspectief niet afgewezen. Invloed op een patiënt uitoefenen om diens situatie draaglijker te maken is vanuit zorgethisch perspectief acceptabel. Zorgethici stellen voor om het hanteren van ethische kwesties op te vatten als een proces, waarin zorg geven en ontvangen een gezamenlijke verantwoordelijkheid is van betrokkenen. ${ }^{\text {"t }}$

Dergelijke zorgethische opvattingen sluiten aan bij het denken en handelen van verpleegkundigen. Een term als 'compassionate interference' biedt ruimte voor de manier waarop verpleegkundigen omgaan met meningsverschillen met patiënten, waarbij ze enerzijds rekening houden met gevoelens, emoties en ervaringen van patiënten van dat moment en anderzijds hun eigen opvattingen van goede zorg vasthouden. In zorgethisch perspectief is goede zorg niet strijdig met het motiveren, stimuleren en overhalen van patiënten tot bepaald gedrag. Denken in termen van zorg als proces, biedt de mogelijkheid om zorg geven en ontvangen te zien als een gezamenlijke verantwoordelijkheid, waarin verpleegkundige en patiënten beide een geheel eigen inbreng hebben.

\section{Hoe ver mag bemoeienis gaan?}

De vraag die zich bij de zorgethische opvatting over het hanteren van meningsverschillen met patiënten opdringt is, hoe ver deze betrokken bemoeienis mag gaan. Deze vraag komt niet alleen naar voren wanneer het denken en handelen van verpleegkundigen van afdeling to wordt bestudeerd. Ze dringt zich ook op in het kader van literatuur over zorgethiek. Vooral omdat in dit 
perspectief een andere betekenis wordt gegeven aan het principe van 'respect voor autonomie'. Niet het zelfbeschikkingsrecht is de belangrijkste leidraad voor het handelen van zorgverleners, maar de vraag of een zorgvrager een leven leidt dat bij hem of haar past (relationele autonomie als authenticiteit). Zorgverleners krijgen de ruimte om tegen vragen van patiënten in te gaan, wanneer ze er van uitgaan dat de zorgontvanger daardoor een leven kan leiden dat voor hem of haar leefbaar is. 'Compassionate interference' is mogelijk om patiënten tegen hun zin, in een situatie te krijgen die uiteindelijk draaglijker voor hen is.

Om te voorkomen dat grenzen worden overschreden en zorg onmogelijk langer te verantwoorden is, stellen zorgethici voor zorg om op te vatten als een proces waarin zowel de zorgverlener als de zorgontvanger een eigen inbreng hebben. Zorgverleners krijgen de verantwoordelijkheid toebedeeld om op een zorgvuldige - en dus betrokken, verantwoorde en zorgzame - manier inzicht te krijgen in de specifieke situatie van de zorgontvangers, omdat ze veronderstellen dat dan de kans het grootst is dat daadwerkelijk tegemoet gekomen wordt aan specifieke zorgbehoeften van concrete anderen. Juist door deze betrokken wijze van zorgverlening wordt geprobeerd zorgontvangers die zorg te geven die ze nodig hebben. Zorgverleners mogen invloed uituefenen op zorgontvangers, als ze er van uit gaan dat de situatie voor zorgvragers draaglijker zal worden. De laatste fase van dit zorgproces, zoals geformuleerd door Tronto (1993), is er op gericht zorg te evalueren en om te bezien of ze voldoet aan de behoefte van een zorgontvanger. Is dat niet het geval, dan begint het zorgproces opnieuw. Net als de principe-ethiek stelt de zorgethiek dat er aandacht moet zijn voor wensen van patiënten. "Aandacht hebben voor wensen van patiënten betekent in het kader van zorgethiek dat er beargumenteerd tegenin gegaan kan worden, wanneer die wensen strijdig zijn met het doel van zorg namelijk, het bestaan voor patiënten zo draaglijk mogelijk maken. Belangrijk onderdeel van het zorgproces, gericht op het zo draaglijk mogelijk maken van het bestaan voor de ander, is volgens zorgethici daarom ook communicatie, reflectie en dialoog tussen alle betrokkenen. Inzicht in de vraag wanneer grenzen worden overschreden kan volgens zorgethici alleen verkregen worden door daarover met alle betrokkenen van gedachten te wisselen. ${ }^{23}$

Dergelijke zorgethische uitgangspunten kunnen gebruikt worden om de kwaliteit van het zorgproces te bestuderen, bijvoorbeeld wanneer het gaat om situaties waarin verpleegkundigen in discussie zijn met patiënten. Ten aanzien van het handelen van de verpleegkundigen van afdeling to kan daardoor geëxpliciteerd worden dat, hoewel zij aandacht hebben voor eigen wensen, gevoelens en emoties van patiënten en hiermee rekening houden, dit geen structureel onderdeel uitmaakt van het beleid van de afdeling. Er wordt niet in 
algemene termen gediscussieerd over de vraag hoe de inbreng van patiënten bij de totstandkoming van het zorgproces kan worden gegaranduerd. De inbreng van patiënten wordt met name besproken op basis van afzonderlijke en individuele momenten, zonder dat daarbij in algemene zin wordt gediscussieerd over de vraag waarom deze inbreng zinvol en noodzakelijk is en hoe' deze kan worden gegarandeerd. De verpleegkundigen zouden zich kunnen afvragen hoe communicatie, reflectie en dialoog met patiënten vorm kan krijgen. Bijvoorbeeld door af te spreken dat patiënten, explicieter dan nu het geval is, betrokken worden bij het totstandkomen en evalueren van het zorgplan. Bovendien zouden de verpleegkundigen onderling, bijvoorbeeld in de setting van moreel beraad, op situaties kunnen reflecteren waarin ze in discussie zijn met patiënten over de inhoud van het zorgproces of wanneer betrokkenen aangeven dat de grenzen aan hun bemoeienis zijn bereikt.

\section{Rigoureus toedelen van verantwoordelijkheid als noodgreep}

Verpleegkundigen komen in situaties terecht, waarin het op een conflict met een patiënt uitloopt. Er kan geen gezamelijke invulling van het zorgproces gevonden worden. De manier waarop verpleegkundigen van afdeling io dergelijke situaties hanteren lijkt op de uitgangspunten van de principe-ethiek, maar er zijn belangrijke verschillen.

Eén verschil is bijvoorbeeld de rol die het verstrekken van infornatic krijgt. Volgens de principe-ethiek moeten verpleegkundigen informatie verstrekk'n en de consequenties van bepaalde handelingsopties laten zien, zodat patiënten zicht hebben op hun situatie en weten waar ze voor kiezen. Daarnaast moeten verpleegkundigen inzicht krijgen in het denk- en redeneerpatroon van patiënten, om vast te kunnen stellen of ze deze informatie kunnen verwerken. Zijn keuzes consistent en duurzaam? Verpleegkundigen van afdeling ro verstrekken ook informatie aan patiënten en bespreken daarbij de consequenties van een bepaalde keuze. Dat doen ze echter niet uitsluitend om patiënten in de gelegenheid te stellen zelf keuzes te maken, maar ook om hun eigen standpunt te verhelderen. Het gaat hen er om patiënten te laten zien waarom zij denken dat het bestaan voor een patiënt uiteindelijk minder draaglijk zal worden. als ze voldoen aan hun vragen. Informatie wordt vooral verstrekt om hun standpunten te verhelderen, zodat ze op basis daarvan met patiënten kunnen overleggen en kunnen zoeken naar overeenstemming. Het gaat er om van elkaar te leren en naar elkaar toe te groeien. Daarom ook proberen verpleegkundigen zicht te krijgen op gevoelens, emoties en ervaringen van patiënten. Niet om de consistentie en de duurzaamheid van een keuze te kunnen bepalen, maar om begrip te krijgen voor patiënten en met elkaar te kunnen communiceren en overleggen, met als doel overeenstemming te bereiken en een situatie te vinden waarin de mening van beiden is verdisconteerd. 
Een ander verschil tussen het denken en handelen van de verpleegkundigen en de uitgangspunten van de verpleegkundige principe-ethiek is dat de eersten vooral zoeken naar overeenstemming. In een principe-ethiek wordt het denken van verpleegkundigen gestuurd in de richting van een dilemma, waarin er sprake is van verschillende handelingsopties. Verpleegkundigen van afdeling ro zoeken naar ruimte voor de eigen wensen van patiënten, maar nemen daarbij hun eigen opvattingen over goede zorg mee. Verpleegkundigen zijn heel creatief in het zoeken naar overeenstemming, bijvoorbeeld door alternatieven aan te bieden, aantrekkelijke omstandigheden te creëren, patienten te verleiden tot bepaald gedrag, om een situatie te vinden waarin beiden zich kunnen vinden. Door het zoeken naar overeenstemming wordt meestal voorkomen dat er een conflict ontstaat waarbij het zorgproces stagneert en er uiteindelijk een keuze moet worden gemaakt tussen twee principes, namelijk zelfbeschikkingsrecht en weldoen. Verpleegkundigen gaan er van uit dat een dergelijke situatie het bestaan van patiënten minder draaglijk zal maken, omdat het zorgproces dan niet langer gezamenlijk wordt gedragen.

Door het zelfbeschikkingsrecht van patiënten en het principe van 'weldoen' centraal te stellen bij meningsverschillen, stevent principe-ethiek als het ware af op het conflict. Díe kwesties staan centraal waarvan verpleegkundigen van afdeling Io zouden zeggen dat ze uit de hand gelopen zij̣n, namelijk situaties waarin het zorgproces niet langer in gezamenlijkheid wordt gedragen. De aandacht van principe-ethiek voor conflictsituaties leidt ertoe dat andere momenten nauwelijks in beeld komen. Dat zijn situaties waarin er discussie is over de invulling van het zorgproces omdat patiënten iets vragen waaraan verpleegkundigen niet zonder meer tegemoet komen, maar waarbij zelfbeschikkingsrecht nog niet in het geding is. Verpleegkundige en patiënt zijn echter wel met elkaar in discussie over de invulling van het zorgproces. Dat zijn de veel voorkomende dagelijkse gebeurtenissen waarin verpleegkundigen met patiënten gezamenlijk zoeken naar een situatie die voor zowel patiënten als verpleegkundigen acceptabel is. In het kader van de principe-ethiek kunnen dergelijke kwesties niet bereflecteerd worden, omdat ze niet zichtbaar zijn. Door conflictsituaties centraal te stellen verdwijnen ook allerlei strategieën uit het zicht die verpleegkundigen inzetten om met patiënten te zoeken naar een invulling van het zorgproces die door beiden gedragen wordt.

Zorgethiek is bruikbaar om conflicten te voorkomen. Wanneer zich desalniettemin conflicten voordoen, hanteert zorgethiek een aantal uitgangspunten om deze te hanteren. Wanneer het gaat om de vraag hoe ver bemoeienis met het leven van patiënten mag gaan, verwijst de zorgethiek naar de kwaliteit van het zorgproces. Of een verpleegkundige al dan niet aan een wens van een patiënt voorbij mag gaan, is vanuit zorgethisch perspectief te evalueren duor het proces te bestuderen waarin een dergelijke beslissing is genomen. 
Is een patiënt in de gelegenheid gesteld te reflecteren op de eigen situatie en daarmee samenhangende wensen en vragen? Is er naar de patiënt geluisterd? Is duidelijk geworden welke betekenis de situatie heeft in het leven van de patiënt? Hebben zorgverleners zich betrokken getoond? Zijn betrokkenen bij de situatie met elkaar in dialoog gegaan? Hebben betrokkenen op hun eigen handelen gereflecteerd? Zijn de waarden die betrokkenen hanteren geëxpliciteerd en overdacht? Antwoorden op dergelijke vragen bepalen uiteindelijk de kwaliteit van een beslissing die is genomen in het kader van het zorgproces. Verpleegkundigen moeten op een zorgzame en verantwoordelijke wijze inzicht krijgen in de manier waarop voor deze patiënt in zijn of haar specifieke omstandigheden de zorg ertoe kan bijdragen dat het bestaan zo draaglijk mogelijk wordt. Wat daarbij uiteindelijk goed is om te doen, bijvoorbeeld al dan niet ingaan tegen een wens van een patiënt, kan niet los van deze specifieke context worden beantwoord. Door middel van communicatie en dialoog moeten betrokkenen streven naar consensus met betrekking tot een vraag wat in een specifieke situatie goed is om te doen.

In deze paragraaf is aangegeven welke vragen relevant zijn als het erom gaat verpleegkundigen te ondersteunen in hun streven om gezamenlijk met patiënten invulling te geven aan het zorgproces. Termen als 'compassionate interference' en 'geprivilegieerde onverantwoordelijkheid' raken de kern van de zorg die verpleegkundigen van afdeling to aan patiënten geven, wanneer ze geconfronteerd worden met vragen van patiënten waaraan ze niet tegemoet willen komen, omdat ze ervan uitgaan dat deze de situatie voor patiënten uiteindelijk niet draaglijker zullen maken.

In tegenstelling tot wat de zorgethiek noodzakelijk vindt, is op afdeling to weinig ruimte voor communicatie, reflectie en dialoog om het handelen te overdenken. De manier waarop morele kwesties zich op afdeling to aandienen lijkt reflectie, communicatie en dialoog noodzakelijk te maken. Zowel gesprekken tussen verpleegkundigen en patiënten als gesprekken tussen verpleegkundigen onderling zouden ingebed moeten worden in de structuur van de afdeling. Juist omdat verpleegkundigen regelmatig in discussie zijn met patiënten over de inhoud van zorg en ook omdat waarden en emoties van betrokkenen daarbij een rol spelen (zoals in paragraaf $\mathrm{x}$ en 3 aan de orde is gekomen) vraagt goed hanteren van morele problematiek om communicatie, reflectie en dialoog. De verpleegkundigen van afdeling io geven aan zelf behoefte te hebben aan onderlinge reflectie. Deze behoefte kan worden ondersteund door te verwijzen naar zorgethiek. Wanneer deze ethiek als ethisch perspectief voor verpleegkundige zorgverlening serieus genomen wordt, moet er ruimte zijn voor reflectie op het eigen handelen en het overdenken van de waarden die daarbij een rol spelen. 


\section{MACHT EN ONMACHT}

Een laatste kenmerk van zorg, dat uit dit onderzoek naar voren is gekomen, betreft het thema 'macht en onmacht'. In hoofdstuk 6 is besproken dat het draaglijker maken van het bestaan van patiënten ook te maken heeft met het creëren van handelingsruimte. Dit onderwerp wordt tot besluit van dit hoofdstuk besproken.

\section{Krijgen en nemen van ruimte}

Verpleegkundigen worden geconfronteerd met behandelbeleid van artsen en met de context van de afdeling, die mede de ruimte bepalen om zorg te geven die zij als goed ervaren. Het krijgen en nemen van ruimte om binnen een specifieke context goede zorg te geven, zou daarom als thema overdacht moeten worden in het kader van verpleegkundige ethiek.

\section{Behandelbeleid van artsen}

In hoofdstuk 6 is aan de orde gekomen dat tegemoet komen aan zorghehoeften van patiënten mede afhankelijk is van het behandelbeleid van artsen. In relatie tot artsen ervaren verpleegkundigen soms te weinig ruimte oin zorg te geven die volgens hen de situatie voor patiënten draaglijker maakt. ${ }^{24}$ Dat doet zich bijvoorbeeld voor wanneer verpleegkundigen zich afvragen wat de zin van een bepaalde behandeling nog is en wanneer de patiënt zijn of haar situatie als ondraaglijk ervaart, terwijl artsen blijven uitproberen wat kán. ${ }^{25}$ Een andere situatie waarin verpleegkundigen niet de zorg kunnen geven die ze zouden willen geven, heeft te maken met de manier waarop artsen patiënten informeren. Soms geven artsen in de ogen van verpleegkundigen de situatie te rooskleurig weer, waardoor de situatie voor patiënten minder draaglijk kan worden omdat ze niet weten wat hen te wachten staat. Verpleegkundigen gaan in dergelijke situaties niet in tegen informatie die artsen aan patiënten geven waarvan zij denken dat die de situatie te rooskleurig weergeeft. ${ }^{26}$ Daar geven ze verschillende redenen voor. Ze willen de vertrouwensrelatie tussen arts en patient niet beschadigen. Bovendien vinden verpleegkundigen het ook de taak van artsen om informatie te verstrekken over prognoses en behandeling. ${ }^{27}$

Om tegemoet te komen aan zorgbehoeften van patiënten hebben verpleegkundigen meer nodig dan beaalde kennis en vaardigheden. Tegemoet komen aan zorgbehoeften heeft te maken met macht, omdat het gaat om de vraag of en hoe verpleegkundigen in staat zijn ruimte te creëren voor hun opvattingen van goede zorg. In relatie tot patiënten zijn verpleegkundigen in staat hun stem te laten klinken. In relatie tot artsen is dat minder het geval. 
Deels is dit het gevolg van de eindverantwoordelijkheid die artsen hebben voor de behandeling. Artsen en verpleegkundigen hebben ieder hun eigen taken, verantwoordelijkheden en bevoegdheden op de afdeling. Dit bepaalt mede de ruimte die ze hebben om de situatie van de patiënt draaglijker te maken. ${ }^{28}$ Wanneer verpleegkundigen zich op het terrein van artsen begeven moeten ze meewerken aan de lijn die door artsen is uitgezet. Dat wil niet zeggen dat verpleegkundigen vervolgens machteloos toezien. Soms worden bijvoorbeeld bepaalde verpleegkundigen naar voren geschoven om de confrontatie met artsen aan te gaan. Verpleegkundigen met veel ervaring op de afdeling hebben vaak veel medische-technische kennis. $\mathrm{Zij}$ worden door artsen eerder als gelijkwaardige gesprekspartner gezien dan verpleeg,kundigen die minder ervaring hebben. Deze verpleegkundigen kunnen daardoor een gesprek met een arts aangaan en de mening van de groep vertolken. Verpleegkundigen hanteren ook meer indirecte strategieën om ruimte te creëren voor hun opvattingen van goede zorg, bijvoorbeeld via patiënten. Ze sturen het denken van patiënten in een richting waardoor vragen over zorg en behandeling op tafel komen. Soms ook gaan verpleegkundigen hun eigen weg. Ze hebben vaak veel medisch-technische kennis, waardoor ze weten hoe ver ze kunnen gaan in het draaglijk maken van de situatie voor patiënten zonder dat hun gezondheid in gevaar komt.

De vraag is of een dergelijke indirecte manier om ruimte te creëren voor hun opvattingen van goede zorg uiteindelijk een adequate manier is om meningsverschillen met artsen te hanteren. Soms lijkt dat wel het geval te zijn, omdat daarmee het zorgproces gaande wordt gehouden en verpleegkundigen er op de één of andere manier in slagen om aan zorgbehoeften te voldoen en de situatie voor patiënten draaglijker te maken. Verpleegkundigen gaan dan op basis van relevante kennis tegen opdrachten van artsen in. Of dat altijd goed is, en wanneer daarbij grenzen overschreden worden, blijft echter onzichtbaar en is daardoor ook niet bekritiseerbaar. Bovendien worden door een dergelijke indirecte strategie om ruimte te creëren voor goede zorg, meningsverschillen niet zichtbaar waardoor ze uiteindelijk uit de hand kunnen lopen. Ze kunnen uitgroeien tot een escalatie waar uiteindelijk iedereen last van heeft. Zoals de situatie die in hoofdstuk 6 is beschreven, waarin een patiënt om euthanasie had gevraagd. In deze situatie, die op een ernstig conflict tussen betrokken partijen was uitgelopen, stond niet alleen de verhouding tussen artsen en verpleegkundigen op het spel, maar kreeg ook de patiënt niet die zorg die de situatie voor haar draaglijker zou maken. Conflicten tussen artsen en verpleegkundigen kunnen volgens Watts et al. (I990) een traumatische ervaring zijn voor betrokkenen. Niet alleen omdat interpersoonlijke verhoudingen tussen artsen en verpleegkundigen beschadigd raken, maar ook omdat zorg voor patiënten eronder leidt. Een slechte werkrelatie tussen artsen en 
verpleegkundigen heeft een negatief effect op zorg. Meningsverschillen zouden moeten worden uitgesproken. Ze kunnen weliswaar leiden tot spanningen, maar ze dragen er ook toe bij dat er wordt beargumenteerd en gecommuniceerd. Dat is altijd beter dan geen communicatie, aldus Lipp (1998).

In het kader van de verpleegkundige ethiek moet aandacht worden besteed aan communicatie en overleg tussen verpleegkundigen en artsen binnen een specifieke context. Deze conclusie is gebaseerd op een aantal bevindingen uit dit onderzoek. Het is zinvol dat artsen en verpleegkundigen hun specifieke opvattingen over goede zorg kenbaar maken, omdat op basis daarvan gesproken kan worden over de ruimte die verpleegkundigen binnen behandelbeleid kunnen of willen innemen om zorg te geven die zij als goed ervaren. Waar en op welke manier belemmert behandelbeleid van artsen op deze afdeling de zorg die verpleegkundigen geven? Hoe kunnen dergelijke situaties voorkomen of goed gehanteerd worden? Op de tweede plaats is communicatie en overleg zinvol, omdat daarin situaties bereflecteerd kunnen worden, waarin verpleegkundigen willen afwijken van specifieke opdrachten van artsen. Hoewel dergelijke indirecte strategieën niet irrationeel lijken, omdat de situatie voor patiënten daardoor draaglijker kan worden, is het van belang ze zichtbaar te maken om erop te kunnen reflecteren. Op de derde plaats is communicatie over goede zorg van belang om situaties, waarin artsen en verpleegkundigen lijnrecht tegenover elkaar staan, te voorkomen. Dergelijke conflicten frustreren relaties en bovendien kunnen ze tot gevolg hebben dat patiënten niet meer díe zorg krijgen die ze nodig hebben. In een verpleegkundige ethiek moet aandacht zijn voor de manier waarop binnen een specifieke context ruimte gecreëerd kan worden voor moreel overleg. Welke structuur faciliteert overleg? Bovendien moet de inhoud van dergelijke overleg vanuit ethiek worden ondersteund. Is het mogelijk vanuit ethische optiek handvatten te formuleren om communicatie en overleg over wederzijdse opvattingen van goede zorg binnen een specifieke setting te bespreken? Hoe kan daarbij voorkomen worden dat de kwestie van macht, die op de werkvloer speelt, daarin onverminderd doorspeelt?

\section{Institutionele ruimte}

Machtskwesties spelen ook een rol in relatie tot de leiding van de afdeling binnen de context van de instelling. In hoofdstuk 6 is besproken dat verpleegkundigen niet altijd die zorg kunnen geven die ze zouden willen geven, door de context van de afdeling. Zorg voor de ene patiënt wordt afgewogen tegen zorg voor een andere patiënt of voor collega's die soms ook zorg en aandacht nodig kunnen hebben. Aangezien er vaak te weinig tijd is, hebben verpleegkundigen regelmatig het gevoel dat ze patiënten te kort doen. Ze ervaren dat als problematisch orndat ze zich betrokken voelen bij patiënten. 
Zij zijn degenen die tegen patiërnten die behandeld worden en opgenomen zijn voor een levensbedreigende ziekte moeten zeggen dat ze geen tijd hebben om te praten. De verpleegkundigen ervaren weinig ruimte om de institutionele context de beïnvloeden. Dat is bijvoorbeeld zichtbaar bij hun pogingen ruimte te creëren voor reflectiemomenten.

Verpleegkundigen van afdeling to hebben behoefte aan structurele momenten van reflectie om hun handelen te bespreken, hun emoties te uiten, positieve en negatieve feedback te krijgen en waardering te ervaren. Het lukt hen echter niet deze ruimte structureel te creëren of te claimen. Voor een deel nemen verpleegkundigen deze ruimte, door hierover tijdens overdrachten te praten. Reflecteren op het eigen handelen kan dan echter alleen tussen de bedrijven door plaatsvinden waardoor vragen vaak alleen opgeworpen worden en niet uitgedacht. Om hun emoties te bespreken zoeken verpleegkundigen hun eigen gesprekspartners binnen en buiten de afdeling.

In hoofdstuk 6 is aan de orde gekomen dat niet alleen tijdsdruk een bijdrage levert aan het ontstaan van morele problematiek, maar dat ook gebrek aan waardering en ondersteuning van verpleegkundigen daaraan kan bijdragen. Verpleegkundigen hebben zelf ondersteuning nodig in de vorm van intervisie, supervisie, functioneringsgesprekken en dergelijke orn zorg te kunnen verlenen aan patiënten.

Verpleegkundige ethiek zou aandacht moeten hebben voor kwesties van macht binnen de context van een specifieke afdeling en instelling. Zijn verpleegkundigen in staat vorm te geven aan hun verantwoordelijkheid tot zorg binnen de context van de afdeling? Welke verbanden bevorderen en ondersteunen de mogelijkheid tot zorg? Ten aanzien van de behoefte aan reflectiemomenten is het zinvol aandacht te besteden aan de vraag welke zorg verpleegkundigen zelf nodig hebben om goede zorg te geven.

\section{Macht en onmacht binnen de verpleegkundige ethiek}

Macht is volgens zorgethici een essentiële dimensie van elke menselijke relatie. Elke menselijke relatie is te typeren als een machtsrelatie. Dit is bij uitstek het geval in zorgrelaties. Zorg en macht zijn met elkaar verweven. Het gaat namelijk altijd om de vraag wie de inhoud van de zorg bepaait. Zorgethici willen een raamwerk bieden om machtsvraagstukken inzichtelijk te maken. Tronto (1993) heeft het concept 'zorg' zo omschreven dat machtsvraagstukken rondom zorg in zicht kunnen komen. Dat doet ze door zorg te omschrijven in verschillende fasen. Door het onderscheid tussen 'zorgen dat' en het concrete 'zorg geven' tot een cruciaal onderscheid te maken, valt het zoeklicht op het verdelen van verantwoordelijkheden. Door te bestuderen hoe verantwoordelijkheden verdeeld zijn, worden kwesties van macht zichtbaar. 
Met een dergelijk raamwerk kan bestudeerd worden of verpleegkundigen in staat zijn die zorg te geven die ze zouden willen geven. In hoofdstuk 4 is inzichtelijk gemaakt dat verpleegkundigen van afdeling to een eigen terrein bekleden, waarin ze proberen de situatie voor patiënten zo draaglijk mogelijk te maken. Ze hebben een eigen morele oriëntatie, waarmee ze proberen de situatie voor patiënten die behandeld worden en opgenomen zijn voor een levensbedreigende ziekte zo draaglijk mogelijk te maken. Er is echter ook een gebied waarin zij geconfronteerd worden met behandelbeleid van artsen en afhankelijk zijn van artsen om bepaalde zorg te geven. Wanneer de fasen van Tronto gebruikt worden om een dergelijk proces inzichtelijk te maken wordt duidelijk dat de verantwoordelijkheid over de zorg is losgeweekt van de zorg zelf. In bepaalde omstandigheden besluiten artsen wat er gedaan moet worden. Verpleegkundigen voeren dat uit. Een dergelijke verdeling van verantwoordelijkheden is inherent aan de relatie tussen artsen en verpleegkundigen. Tegelijkertijd hebben verpleegkundigen een eigen verantwoordelijkheid ten aanzien van de zorg die ze geven. Deze verantwoordelijkheid is vaak minder duidelijk. Wat is de specifieke verantwoordelijkheid van verpleegkundigen op een afdeling? Hoe verhoudt zich dat tot het behandelbeleid van artsen? Dergelijke vragen zouden expliciet aandacht moeten krijgen op een afdeling om vervolgens de verdeling van verantwoordelijkheden te kunnen bespreken. Wanneer is het terecht dat artsen de verantwoordelijkheid hebben over de zorg die verpleegkundigen geven en wanneer is dat niet het geval?

Datzelfde geldt voor de ruimte die verpleegkundigen krijgen en nemen binnen de context van een afdeling of instelling. Ook deze kan bestudeerd worden vanuit het raamwerk van Tronto. In hoeverre zijn verpleegkundigen binnen de context van de afdeling en instelling in staat hun opvattingen over goede zorg naar voren te brengen en invloed uit te oefenen op het management en het beleid hier ruimte voor te creëren? Voeren zij vooral zorg uit en is de inhoud daarvan met name door anderen bepaald? Of geven verpleegkumdigen een eigen invulling aan de zorg binnen de context van de afdeling en instelling? In dit onderzoek is duidelijk geworden dat verpleegkundigen gedeeltelijk zelf invulling geven aan het zorgproces, bijvoorbeeld door aandacht te besteden aan de draaglijkheid van de situatie van patiënten. Daarnaast ondervinden ze ook beperkingen bij het verrichten van verzorgende activiteiten. Het draaglijk maken van de situatie van patiënten is niet altijd verdisconteerd in de ruimte die binnen de afdeling gegeven is om te verplegen. ${ }^{29}$ Datzelfde geldt voor het creëren van zorg voor verpleegkundigen zelf. In het denken en handelen van verpleegkundigen van afdeling Io is zichtbaar dat ze weinig ruimte ondervinden deze te organiseren. Hun vragen om supervisie of intervisie om te reflecteren op hun handelen en emoties worden niet gehonoreerd en er is onvoldoende ruimte om door middel van functione- 
ringsgesprekken of informeel contact feedback te krijgen op en waardering voor het handelen.

De zorgethiek geeft een raamwerk om machtsvraagstukken inzichtelijk te maken. Daarbij wordt echter niet uitgewerkt hoe met ongelijke machtsverhoudingen omgegaan kan worden. Wanneer zichtbaar is dat verpleegkundigen onvoldoende in staat zijn een ruimte te creëren om zorg te geven die zij als goed ervaren, hoe kan een dergelijke situatie dan worden gekeerd? Communicatie, dialoog en overleg worden ook hier weer naar voren geschoven als leidraad voor het hanteren van meningsverschillen en conflicten. Juist omdat verpleegkundigen zich in een ongelijkwaardige positie ten opzichte van artsen en de instelling bevinden, worden machtsverschillen daarmee echter niet zonder meer opgeheven. Dit betekent niet dat het instellen van communicatiestructuren zinloos is. Zoals uit hoofdstuk 6 blijkt, kan afwezigheid van overleg met artsen er in ieder geval toe leiden dat men tegenover elkaar komt te staan. Wanneer men niet om de tafel gaat zitten, ontbreekt niet alleen de mogelijkheid tot inspraak maar wordt ook de verdeling van verantwoordelijkheden niet duidelijk. Wanneer beslissingen niet gezamenlijk worden genomen kunnen ze niet gezamenlijk worden gedragen. Uiteindelijk leidt dat tot een situatie van gemopper, onzekerheid en verontwaardiging ${ }^{10}$, wordt de kwaliteit van zorg voor patiënten geschaad en wordt de relatie tussen alle betrokkenen ondermijnd.

\section{ConCLUSIE}

In dit hoofdstuk is een aantal kenmerken van zorg uitgewerkt, die uit het denken en handelen van verpleegkundigen van afdeling io naar voren zijn gekomen. Deze zijn vergeleken met theoretische punten en discussies in de verpleegkundige ethiek. Hierbij is met name de zorgethiek betrokken, omdat deze ethiek ook is gebruikt om morele ervaringen inzichtelijk te maken. Beide andere perspectieven, principe-ethiek en verpleegkundige deugdethiek, zijn indien nodig ingezet om contrast te maken of om de bespreking aan te scherpen. Tot besluit van dit hoofdstuk worden de thema's samengevat die relevant zijn om in het kader van verpleegkundige ethiek verder te bestuderen en uit te werken. Daarbij wordt ook de bruikbaarheid van zorgethiek aangevoerd.

Uit dit onderzoek komt de zorgethiek als relevant perspectief naar voren om morele ervaringen van verpleegkundigen te verwoorden, te overdenken, aan te scherpen en uit te werken.

De zorgethiek is op de eerste plaats bruikbaar om de verbondenheid van zorgen en ethiek verder te bestuderen. In paragraaf $\mathrm{I}$ is betoogd dat verpleeg- 
kundigen opvattingen van goede zorg hanteren die van invloed zijn op de zorg die ze geven. Bovendien hangen zorgen en ethiek met elkaar samen omdat allerlei praktische en technische activiteiten die ogenschijnlijk niets met ethiek van doen hebben, moreel zijn. Vanuit deze bevindingen wordt in dit onderzoek beargumenteerd dat ethici moeten kijken en luisteren naar verpleegkundigen op de werkvloer om zicht te krijgen op de aard en omvang van ethische kwesties. Deze bevinding sluit aan bij het pleidooi van zorgethici om zorg als praktijk op te vatten. Dit praktijk-denken kan in het kader van verpleegkundige ethiek gebruikt worden om morele ervaringen van verpleegkundigen verder uit te werken en aan te scherpen.

Op de tweede plaats is het concept 'zorgrationaliteit' uit de zorgethiek bruikbaar om de wijzen waarop verpleegkundigen van afdeling ro zorgbehoeften hanteren verder te bestuderen. In paragraaf 2 is betoogd dat het hanteren van morele kwesties een eigen rationaliteit kent waarin doen, kennen, voelen, redeneren en overleggen samenkomen. Om de situatie voor patiënten draaglijker te maken verrichten verpleegkundigen activiteiten waarbij ze gebruik maken van theoretische kennis, praktische kennis en relationele vaardigheden. Bovendien overleggen ze met andere zorgverleners en denken ze samen na over de vraag wat goed is om te doen. De zorgethiek maakt deze zorgrationaliteit tot onderwerp van studie. Ze kan gebruikt worden om het denken en handelen van verpleegkundigen verder te bestuderen.

In zorgethische literatuur wordt het thema van 'betrokkenheid' bestudeerd. In paragraaf 3 is aangegeven dat dit thema een belangrijk kenmerk is van de zorg die verpleegkundigen aan patiënten geven. Daarom is een breed scala aan betekenissen van betrokkenheid besproken, zowel vanuit morele ervaringen van verpleegkundigen als vanuit de zorgethiek. Het thema 'betrokkenheid' wordt daarbij zichtbaar als: antwoord op kwetsbaarheid, voorwaarde voor vertrouwen, voorwaarde voor kennis, als valkuil en als identiteit.

In paragraaf 4 is uiteengezet dat 'discussie met patiënten' een belangrijk kenmerk van zorg is. Verpleegkundigen zijn regelmatig in gesprek met patiënten over de vraag wat goed is om te doen op een bepaald moment. Hierbij is het handelen van verpleegkundigen erop gericht een situatie te creëren die voor beiden leefbaar en werkbaar is. Daarom wordt ruimte gecreëerd voor patiënten om hun gevoelens, ervaringen, meningen en eigen opvattingen over goede zorg naar voren te brengen. Tegelijkertijd brengen verpleegkundigen hun eigen opvattingen over goede zorg naar voren. Verpleegkundigen zoeken naar overeenstemming met patiënten, omdat ze ervan uitgaan dat een gezamenlijk gedragen zorgproces de situatie voor patiënten draaglijker zal maken. Het handelen van verpleegkundigen is er daarom op gericht conflicten te voorkomen en de communicatie open te houden. De zorgethiek is bruikbaar om verpleegkundigen te ondersteunen in hun discussie met 
patiënten om tot een gezamenlijke invulling van het zorgproces te komen. Termen uit de zorgethiek als 'compasionate interference', 'geprivilegieerde onverantwoordelijkheid', 'relationele autonomie als authenticiteit' en 'vertrouwen' zijn bruikbaar om het denken en handelen van verpleegkundigen in het kader van verpleegkundige ethiek verder te bestuderen.

Tenslotte is in dit hoofdstuk het onderwerp 'macht en onmacht' besproken. Het raamwerk van zorg, zoals dat is uitgewerkt door Tronto in een proces van vier fasen, is bruikbaar om kwesties van macht in de verpleging aan de orde te stellen. 'Macht en onmacht' is een relevant onderwerp voor verpleegkundige ethiek, omdat de context waarin wordt gezorgd mede bepaalt hoeveel ruimte verpleegkundigen ervaren om goede zorg te geven. Dit geldt bijvoorbeeld voor het behandelbeleid van artsen en voor de institutionele context waarin zorg wordt verleend. Deze moeten daarom betrokken worden bij het inzichtelijk maken van morele kwesties die spelen in de dagelijkse zorgverlening. Met behulp van het raamwerk van Tronto kunnen verdelingen van verantwoordelijkheden in de zorg zichtbaar worden. Dan blijkt bijwoorbeeld dat verpleegkundigen als gevolg van de context van behandelbeleid en het beleid binnen de instelling, soms zorg uitvoeren waarvan zij de inhoud niet zelf bepalen. Dat heeft consequenties voor hun ervaringen met zorgverlenen. Het is van belang kwesties van macht en verantwoordelijkheid zichtbaar te maken. Inzicht in het denken en handelen van verpleegkundigen en in hun opvattingen van goede zorg is hierbij een belangrijke voorwaarde, omdat de ruimte om de inhoud van de zorg te bepalen op subtiele manier verweven is met het dagelijks denken en handelen.

De resultaten van het empirisch onderzoek bieden aanknopingspunten om de relevantie van de zorgethiek voor de verpleging te vergroten.

Zowel in paragraaf $\mathrm{I}$ als in paragraaf $\mathrm{z}$ is aangegeven dat in het kader van zorgethiek de aandacht uitgaat naar relationele en cognitieve vaardigheden die nodig zijn om de specifieke persoon en situatie van een patiënt te leren kennen, om zorgbehoeften adequaat te kunnen signaleren en hanteren. Met naine fase I, 2 en 4 van het zorgproces van Tronto zijn in de zorgethiek verder uitgewerkt, terwijl fase 3 - de concrete activiteit van het zorgen - tot nog toe onderbelicht is gebleven. Een zorgethiek die relevant wil zijn om voor de verpleegkundige praktijk, zou zich ook moeten richten op het uitwerken van fase 3. Bevindingen uit deze studie kunnen daarvoor aanknopingspunten bieden. Verpleegkundigen op de werkvloer gebruiken niet alleen relationele vaardig. heden om tegemoet te komen aan zorgbehoeften van patiënten. Ze verrichten veel activiteiten om de draaglijkheid van het bestaan van patiënten te bevorderen. Bovendien moeten verpleegkundigen ook technisch, praktisch, creatief, assertief, eigenwijs of handig zijn om dat te doen. 
In paragraaf 4 is zorgethiek naar voren gekomen als relevant perspectief om verpleegkundigen te ondersteunen bij hun pogingen conflicten met patiënten te voorkomen, in situaties waarin er discussie is over de inhoud van het zorgproces. Van belang is dat zowel patiënten als verpleegkundigen een eigen inbreng hebben in dit proces en dat zij de bereidheid hebben naar elkaar toe te groeien en van elkaar te leren. In uiterste situaties wordt een uitweg gezocht door verantwoordelijkheden rigoureus toe te delen. Van belang blijft evenwel dat verpleegkundigen niet denken in termen van beslissingsmacht, maar in termen van verantwoordelijkheden. Bovendien blijft het handelen van verpleegkundigen erop gericht om samen met de patiënt invulling te geven aan het zorgproces. Op basis van deze bevindingen kan geconcludeerd worden dat in het kader van verpleegkundige ethiek de verhouding tussen zorgethiek en principe-ethiek, in relatie tot het voorkomen en hanteren van conflicten, nader onderzocht zou moeten worden.

De zorgethiek schuift communicatie, reflectie en dialoog naar voren als belangrijke voorwaarden voor zorg (als een reactie op morele kwesties). Deze worden ingezet als middel om op opvattingen van goede zorg te reflecteren, afspraken te maken over opvattingen van goede zorg die relevant zijn binnen een specifieke zorgpraktijk en vragen te stellen bij de bruikbaarheid van deze opvattingen in bepaalde omstandigheden. Communicatie, reflectie en dia. loog zijn ook de instrumenten die ingezet worden om binnen de relatie tus. sen zorggever en ontvanger, de inhoud van de zorg vast te stellen of met elkaar te overleggen om tot overeenstemming te komen. Deze vaardigheden worden door zorgethici ook genoemd als het gaat om het hanteren van machtskwesties in de zorg. Betrokkenen moeten met elkaar in gesprek gaan over de verdeling van verantwoordelijkheden. Wie krijgt welke verantwoordelijkheden toebedeeld? Wat zijn daar de consequenties van, voor ervaringen van betrokkenen? Is het terecht verantwoordelijkheden op deze manier te verdelen? Hoe kunnen bepaalde betrokkenen ondersteund worden om meer invloed uit te oefenen op de inhoud van zorg? Zorgethici hechten om verschillende redenen veel waarde aan communicatie, reflectie en dialoog, tegelijkertijd is er nog onvoldoende aandacht voor de inhoud ervan. Hoe kunnen communicatie en reflectie ertoe bijdragen dat patiënten díe zorg krijgen die daadwerkelijk de draaglijkheid van hun bestaan zal bevorderen? Hoe kan bevorderd worden dat overleg het niveau van gekibbel en uitwisselen van gevoeligheden en emoties overstijgt? Ook is er nog onvoldoende aandacht voor de institutionalisering van reflectie. Hoe kan de structuur van een organisatie ertoe bijdragen dat zorgverleners met patiënten en elkaar in gesprek kornen en reflecteren op het eigen en andermans handelen?

Op basis van de studie naar het denken en handelen van verpleegkundigen van afdeling ro, zijn in dit boek onderwerpen geformuleerd die verder bestu- 
deerd en uitgewerkt kunnen worden in het kader van de verpleegkundige ethiek. Zorgethiek is een bruikbaar perspectief om de morele ervaringen van verpleegkundigen te verwoorden, aan te scherpen en uit te werken. Daarnaast kunnen op basis van het onderzoek naar morele ervaringen van verpleegkundigen, nieuwe onderwerpen op de agenda van de zorgethiek geplaatst geworden. Om de bruikbaarheid van dit perspectief voor de verpleging te vergroten, is het van belang meer aandacht te besteden aan de activiteiten van het zorgen (fase 3 van Tronto) en de inhoud en institutionalisering van communicatie, reflectie en dialoog. 



\section{EPILOOG}

In dit proefschrift zijn morele ervaringen van verpleegkundigen met dagelijkse zorgverlening bestudeerd. Daarbij is gebruik gemaakt van verpleeg. kundige ethiek. In de empirische hoofdstukken $(4,5$ en 6) zijn morele ervaringen van verpleegkundigen van afdeling ro belicht. In deze hoofdstukken komt verplegen in beeld als een moreel geladen activiteit, omdat dit proces erop gericht is de situatie voor patiënten zo draaglijk mogelijk te maken. Bovendien is zichtbaar geworden dat het draaglijker maken van de situatie voor patiënten een complex proces is. Verpleegkundigen moeten zich namelijk voortdurend afvragen wat een patiënt nodig heeft om de situatie als draaglijk te ervaren. Welke zorgactiviteiten kunnen verricht worden om de situatie voor deze patiënt zo draaglijk mogelijk te maken? Hoe kunnen verpleegkundigen medische en technische handelingen zo uitvoeren dat de draaglijkheid van de situatie voor een patiënt zo min mogelijk wordt ondermijnd? Verplegen is bovendien complex omdat de antwoorden op dergelijke. vragen niet zonder meer vaststaan, maar onderwerp zijn van interpretatie en overleg. De complexiteit wordt nog versterkt doordat verpleegkundigen geconfronteerd worden met moeilijkheden, problemen en belemmeringen bij het geven van goede zorg. Bijvoorbeeld omdat er verschil van mening is over de inhoud van de zorg of omdat de context van de afdeling (werkdruk) of het behandelbeleid van artsen de bewegingsvrijheid van verpleegkundigen beperken.

Vanuit dit beeld van verplegen, dat uit morele ervaringen van verpleegkundigen van afdeling ro naar voren is gekomen, wordt tot besluit van dit boek teruggekomen op de aanleiding van dit onderzoek. De veronderstelling was dat verpleegkundigen gefrustreerd en gestresst kunnen raken of een burn-out oplopen, wanneer ze niet díe zorg kunnen geven die ze zouden willen geven om de draaglijkheid van het bestaan van patiënten zo veel mogelijk te bevorderen én wanneer ze onvoldoende ondersteuning ervaren bij het uitvoeren van die zorg. Hoe kan inzicht in morele ervaringen van verpleegkundigen ertoe bijdagen dat de kwaliteit van hun werken kan worden verbeterd? Deze vraag wordt in paragraaf 2 van dit hoofdstuk besproken. In paragraaf I wordt eerst gereflecteerd op dit onderzoek. 


\section{REFLECTIE OP HET ONDERZOEK}

In deze paragraaf wordt gereflecteerd op het uitgevoerde onderzoek. Daartoe worden de volgende vragen besproken. Was het mogelijk met behulp van de zorgethiek morele ervaringen van verpleegkundigen met dagelijkse zorgverlening inzichtelijk te maken én te bespreken? Wat is de reikwijdte van de bevindingen?

\section{De zorgethiek als theoretisch kader}

In hoofdstuk 2 zijn verschillende ethische stromingen binnen de verpleging bestudeerd, met als doel om een perspectief te kiezen dat bruikbaar is om morele ervaringen van verpleegkundigen met dagelijkse zorgverlening in een empirisch onderzoek zichtbaar te maken. In hoofdstuk 3 is de keuze om zorgethiek daarvoor te gebruiken beargumenteerd. In dit hoofdstuk wordt ingegaan op de vraag of het perspectief van de zorgethiek het gewenste resultaat heeft opgeleverd. Zijn morele kwesties die samenhangen met dagelijkse zorgverlening inzichtelijk gemaakt? Was het mogelijk op deze morele ervaringen te reflecteren?

\section{Dagelijkse morele kwesties}

Zorgethici pleiten ervoor door middel van kwalitatieve onderzoeksmethoden betrokkenen zelf aan het woord te laten om de aard en omvang van morele kwesties inzichtelijk te maken. Een dergelijke opvatting past binnen de algemene doelstelling van kwalitatief onderzoek, waarin het begrijpen van bepaald gedrag van mensen centraal staat. In dit onderzoek is daarom gebruik gemaakt van participerende observaties en semi-gestructureerde diepte-interviews om morele ervaringen van verpleegkundigen te bestuderen. In de empirische hoofdstukken 4, 5 en 6 werden op basis van het verzamelde máteriaal morele ervaringen van verpleegkundigen van afdeling to belicht. Daar werd zichtbaar dat met behulp van open methoden van dataverzameling, diepgaand inzicht verworven kon worden in beweegredenen en activiteiten van verpleegkundigen.

Om dit inzicht te verwerven in morele ervaringen van verpleegkundigen is niet alleen gebruik gemaakt van methodologische uitgangspunten van de zorgethiek, maar is ook gebruik gernaakt van een aantal inhoudelijke uitgangspunten. Om inzicht te krijgen in morele ervaringen van verpleegkundigen met dagelijkse zorgverlening heeft het zorgproces zelf centraal gestaan en is bestudeerd aan welke zorgbehoeften van patiënten verpleegkundigen tegemoet willen komen omdat deze volgens hen samenhangen met het in stand houden of herstellen van de wereld van patiënten zodat deze er zo goed 
mogelijk in kunnen leven. Bovendien is bestudeerd hoe verpleegkundigen aan deze zorgbehoeften tegemoet willen komen en in welke situaties zich daarbij problemen voor doen.

Door betrokkenen zelf aan het woord te laten over zorgbehoeften en hun activiteiten te bestuderen was het mogelijk antwoord te geven op vragen als: Wat verstaan zij onder goede zorg? Waarom is deze zorg van belang voor patienten? Hoe proberen ze deze zorg te geven? Welke activiteiten verrichten zij om de situatie voor patiënten draaglijker te maken? Welke moeilijkheden, problemen of belemmeringen komen ze daarbij tegen?; Hoe gaan ze daarmee om? Wat hebben verpleegkundigen zelf nodig om zorg te kunnen verlenen? Op basis van het inzicht in morele ervaringen van verpleegkundigen dat in dit onderzoek is verworven door gebruik te maken van de methodologische en inhoudelijke aanwijzingen van zorgethiek, wordt geconcludeerd dat dit perspectief bruikbaar is om morele kwesties die samenhangen met dagelijkse zorgverlening inzichtelijk te maken.

\section{Wederzijdse reflectie}

De zorgethiek stelt voor om open manieren van dataverzameling te gebruiken om morele ervaringen inzichtelijk te maken. Door op deze manier informatie te verzamelen over morele kwesties die samenhangen met de dagelijkse zorg die verpleegkundigen aan patiënten geven, was het niet alleen mogelijk inzicht te verwerven, maar konden ook thema's worden geformuleerd waar zowel de praktijk van verpleegkundige zorgverlening als verpleegkundig ethici iets van kunnen leren.' In hoofdstuk 7 zijn theorie en praktijk met elkaar in verband gebracht. De bevindingen uit de empirische hoofdstukken werden daar gerelateerd aan ethische perspectieven, met name dat van de zorgethiek. Daartoe zijn uit het empirisch materiaal thema's gedistilleerd die morele ervaringen van verpleegkundigen van afdeling ro typeren. Deze zijn vervolgens besproken in het licht van het zorgethisch perspectief dat in hoofdstuk 2 is beschreven. Beide andere perspectieven - verpleegkundige principe-ethiek en verpleegkundige deugdethiek - die ook in dat hoofdstuk werden bestudeerd, zijn bij de bespreking betrokken indien dat nodig was om contrast te maken of om het thema verder uit te diepen. Door morele ervaringen van verpleegkundigen te confronteren met ethische theorievorming, was het mogelijk voor zowel ethici als practici aandachtspunten te formuleren die nadere uitwerking en aandacht verdienen.

Zo is bijvoorbeeld geconstateerd dat zorgethiek, wil deze relevant zijn voor de verpleging, meer aandacht zou moeten besteden aan de activiteit van het zorgen (fase 3 van Tronto 1993), omdat het morele juist verbonden is met het concrete handelen van verpleegkundigen. Bovendien zou naast relationele vaardigheden binnen de zorgethiek ook aandacht kunnen zijn voor 
niet-relationele vaardigheden die worden ingezet om de draaglijkheid van het bestaan van patiënten te bevorderen, zoals bijvoorbeeld creativiteit, assertiviteit, handigheid of eigenwijsheid. In hoofdstuk 7 is beargumenteerd dat er in de zorgethiek nagedacht zou moeten worden over de inhoud en institutionele inbedding van communicatie, dialoog en reflectie, die door zorgethici naar voren geschoven worden als belangrijke voorwaarden voor zorg. Gesprekken tussen zorgverleners onderling en met patiënten moeten zo vorm krijgen dat ze er toe bijdragen dat zorg geboden wordt die de draaglijkheid van de situatie voor patiënten bevordert en de situatie voor betrokkenen werkbaar en leefbaar maakt. Hierbij zou de invloed van machtsverhoudingen op een dergelijk overleg betrokken kunnen worden.

De zorgethiek kan gebruikt worden om het handelen van verpleegkundigen verder te bestuderen. Met behulp van zorgethiek kan bijvoorbeeld de verbondenheid van zorgen en ethiek verder worden uitgewerkt, door gebruik te maken van het concept 'zorgen als praktijk'. Ook kan het belang van communicatie, reflectie en dialoog voor de praktijk worden onderstreept, hoewel de inhoudelijke en structurele invulling hiervan nog onvoldoende duidelijk zijn. Opvattingen van zorgethici kunnen bijvoorbeeld worden ingezet om aan betrokkenen bij de zorg duidelijk te maken dat het van belang is om waarden die gehanteerd worden inzichtelijk te maken en ter discussie te stellen. Ook kunnen opvattingen van zorgethici over verantwoordelijke en betrokken zorgverlening gebruikt worden om het handelen van verpleegkundigen verder aan te scherpen. Bovendien biedt de zorgethiek handvatten om verdelingen van verantwoordelijkheid en daarmee kwesties van macht voor het voetlicht te brengen, bijvoorbeeld om op de werkvloer zicht te krijgen op de ruimte die verpleegkundigen in hun zorgend handelen ervaren om goede zorg te geven.

Op basis van bovenstaande bevindingen kan geconcludeerd worden dat de inhoudelijke en methodologische uitgangspunten van de zorgethiek bruik. baar zijn om morele kwesties inzichtelijk te maken én te bespreken, die samenhangen met de dagelijkse zorg die verpleegkundigen aan patiënten geven. Bovendien kan inzicht in morele ervaringen van verpleegkundigen, dat verworven is door open manieren van dataverzameling te gebruiken, een productief gesprek op gang kan brengen tussen theorie en praktijk. Door morele ervaringen van verpleegkundigen in sarnenhang met ethische perspectieven te bespreken, kunnen practici en ethici leren van elkaar.

\section{Reikwijdte van de bevindingen}

In dit onderzoek is ervoor gekozen morele ervaringen van verpleegkundigen van één afdeling te bestuderen. Reden daarvoor is dat de voorkeur uitging 
naar het verwerven van diepgaand inzicht in morele ervaringen van verpleegkundigen. Dat is een tijdrovende manier van onderzoek doen. In een periode van 5 maanden zijn daarvoor participerende observaties verricht, de bevindingen beschreven en gedeeltelijk geanalyseerd. De keuze voor één afdeling heeft als consequentie dat de resultaten niet zonder meer generaliseerbaar zijn naar andere zorgpraktijken, in ieder geval niet zodanig dat kan worden geconcludeerd dat verplegenden daar dezelfde morele ervaringen zouden hebben. Door de keuze voor één afdeling, evenals door de keuze voor zorgethiek als theoretisch kader, is in de empirische hoofdstukken één specifiek beeld gecreëerd van morele ervaringen van verpleegkundigen. Dat wil niet echter zeggen dat de resultaten uit dit onderzoek niet breder bruikbaar zijn. Dit wordt in het nu volgende beargumenteerd.

\section{Een specifiek beeld}

In dit onderzoek is ervoor gekozen om opvattingen van goede zorg te bespreken vanuit het perspectief van verpleegkundigen. Dat heeft consequenties voor de resultaten.

Er is gezocht naar opvattingen van het goede, waardoor vrijwel uitsluitend het goede zichtbaar is geworden. Door deze insteek is slechts indirect de andere kant van de zorg te zien. Bijvoorbeeld, als in hoofdstuk 6 wordt besproken dat verpleegkundigen vaak keuzes moeten maken, waarbij ze altijd het gevoel hebben dat ze iemand te kort doen. Hierdoor zullen zich zeker situaties voordoen dat patiënten zich ook tekort gedaan voelen. Wanneer het perspectief van zorgethiek was vertaald in een andere vraag, bijvoorbeeld 'aan welke zorgbehoeften van patiënten wordt niet voldaan?', was een ander beeld naar voren gekomen. Door te zoeken naar goede zorg is vooral goede zorg in beeld gebracht.

In dit onderzoek is er bovendien voor gekozen het verhaal van verpleegkundigen op te schrijven. De keuze om verpleegkundigen centraal te stellen in dit onderzoek is een gevolg van aanleiding, vraag- en doelstellingen. In dit onderzoek worden morele ervaringen van verpleegkundigen bestudeerd vanuit de opvatting dat ze niet díe zorg kunnen geven die ze zouden willen om het bestaan van patiënten draaglijker te maken, waardoor ze gefrustreerd en gestresst kunnen raken of een burn-out oplopen. Doel van dit onderzoek is een bijdrage te leveren aan het bevorderen van de kwaliteit van werken van verplegenden en verzorgenden. Daarom is ervoor gekozen afdeling ro in beeld te brengen vanuit handelingen en beweegredenen van verpleegkundigen.

De resultaten van dit onderzoek zijn het gevolg van de keuze om morele ervaringen van verpleegkundigen met goede zorgverlening centraal te stellen. Een onderzoek waarin patiënten aan het woord gelaten worden, zou een verrijking zijn van het beeld dat in dit onderzoek naar morele aspecten van 
verplegen naar voren is gekomen. Ook onderzoek naar morele ervaringen van artsen of familieleden kan een verrijking geven.

\section{Overdraagbaarheid van de resultaten}

In dit onderzoek zijn morele ervaringen van verpleegkundigen van afdeling Io zichtbaar gemaakt. Door gegevens te analyseren die zijn verzameld met behulp van inhoudelijke en methodologische aanwijzingen van zorgethiek, is zichtbaar geworden hoe verpleegkundigen proberen de draaglijkheid van het bestaan van patiënten te vergroten en welke problematische situaties ze daarbij tegenkomen. Op twee manieren zijn de resultaten van dit onderzoek breder bruikbaar.

Op de eerste plaats kunnen morele kwesties die in dit hoofdstuk naar voren zijn gekomen dienen als aanknopingspunt voor het bespreken van morele ervaringen van verplegenden en verzorgenden binnen andere contexten. ${ }^{2}$ In hoofdstuk 3 is beargumenteerd waarom voor een hematologie oncologie afdeling is gekozen. Dit is een afdeling waar patiënten behandeld en verpleegd worden die intensieve chemokuren krijgen, vaak aangevuld met een BeenMergTransplantatie (BMT). Hoewel dit daardoor een afdeling, lijkt waar vooral technische zorg verleend wordt of patiënten met name psychisch begeleid worden, is dat niet het geval. Op deze afdeling worden allerlei zorgende handelingen verricht die ook binnen andere contexten voor verpleging en verzorging worden uitgevoerd. Verpleegkundigen helpen patiënten met wassen, aankleden, eten, drinken. Ze geven medicatie, verrichten medisch-technische handelingen, begeleiden patiënten en hun familie en verstrekken informatie. Dergelijke dagelijkse zorg is het uitgangspunt geweest om morele ervaringen van verpleegkundigen inzichtelijk te maken. Deze zorg staat ook centraal binnen veel andere contexten van verpleging en verzorging.

Dat wil niet zeggen dat er zich op een hematologie oncologie afdeling geen gangbare ethische kwesties voor hebben gedaan. In hoofdstuk 6 is een situatie besproken, waarin een patiënt om euthanasie had gevraagd. Echter, ook dan is bij het observeren van deze situatie de dagelijkse zorgverlening het uitgangspunt geweest. In dit onderzoek is juist voor een hematologie oncologie afdeling gekozen om te laten zien dat, ondanks het feit dat er gangbare ethische kwesties spelen, morele ervaringen van verpleegkundigen toch in samenhang met de dagelijkse zorg zichtbaar gemaakt kunnen worden. Ook wanneer zich in het oog springende ethische kwesties voordoen, kan bestudeerd worden hoe verpleegkundigen proberen in de dagelijkse zorg het bestaan voor deze patiënten zo draaglijk mogelijk te maken.

Door aan te sluiten bij dagelijkse zorg, zijn morele kwesties naar voren gekomen die ook voor verplegenden en verzorgenden binnen andere contexten herkenbaar zullen zijn. Het is ook aannemelijk dat dit het geval is, omdat 
ander onderzoek tot soortelijke resultaten leidt. Recentelijk uitgevoerd onderzoek in opdracht van het Ministerie van Volksgezondheid, Welzijn en Sport (Thiel \& Hoven 1999) laat bijvoorbeeld zien dat verplegenden en verzorgenden het van belang vinden aandacht te hebben voor emoties en ervaringen van zorgontvangers en het bieden van een prettige woonomgeving of zinvolle dagbesteding. Bovendien komt ook uit dat onderzoek naar voren dat verplegenden en verzorgenden in de dagelijkse praktijk weinig ruimte ondervinden om deze zorg te geven.

De resultaten uit het voorliggende proefschrift zijn breder bruikbaar omdat verplegenden en verzorgenden uit andere praktijken van verpleging en verzorging hun eigen ervaringen kunnen vergelijken met de analyses uit dit proefschrift. Op basis van overeenkomsten en verschillen kunnen verplegenden en verzorgenden uit andere zorgpraktijken bepalen in welk opzicht de bevindingen voor henzelf te transporteren zijn. Maso en Smaling (I998) spreken in dit verband over de overdraagbaarheid van de bevindingen. Hierbij gaat het om de bruikbaarheid of benuttingswaarde van het onderzoek. Niet de onderzoeker bepaalt welke overeenkomsten er bestaan tussen de onderzochte situatie en niet-onderzochte situaties, maar de lezer. Daartoe moet de lezer dan wel in staat gesteld worden. Daarom is in dit onderzoek het empirische materiaal uitvoerig aan de orde gekomen. Citaten en situatieschetsen geven de lezer niet alleen de mogelijkheid de analyse te volgen. De beschrijvingen ondersteunen de mogelijkheid vergelijkingen te maken met. andere contexten. Verplegenden en verzorgenden binnen andere praktijken kunnen zich afvragen hoe de in dit boek beschreven morele ervaringen zich verhouden tot die van henzelf. Ook verschillen kunnen aanleiding geven tot overdenking en reflectie op de eigen morele praktijk.

Op de tweede plaats zijn de bevindingen uit dit onderzoek breder bruikbaar, omdat ze kunnen dienen als aanknopingspunt voor reflectie op de verpleegkundige ethiek. De thema's die op basis van morele ervaringen van verpleegkundigen uit dit onderzoek aan verpleegkundige ethiek zijn aangereikt voor verdere studie, zijn niet alleen van belang voor verpleegkundigen van afdeling ro. Meer inzicht in de invloed van opvattingen van goede zorg op het signaleren van zorgbehoeften is een thema dat relevant is voor alle praktijken van verpleging en verzorging. Dat geldt ook voor de thema's van. 'zorgrationaliteit', 'betrokkenheid', 'discussies met patiënten' en 'macht'. Het overdenken van de onderwerpen die uit dit onderzoek naar voren zijn gekomen, hoeft niet verbonden te blijven met deze specifieke context, waarin. ze zijn geïdentificeerd. Ze kunnen in het kader van verpleegkundige ethiek worden aangescherpt en uitgediept. Ook kunnen ze aanknopingspunten zijn voor verder empirisch en filosofisch onderzoek. 
In deze paragraaf is gereflecteerd op de methodologische en inhoudelijke uitgangspunten die in dit onderzoek zịn gehanteerd. Op basis van deze reflectie wordt geconcludeerd dat deze uitgangspunten bruikbaar zijn om morele ervaringen van verpleegkundigen met dagelijkse zorgverlening inzichtelijk te maken én te bespreken. De bevindingen in dit boek zijn daarom overdraagbaar naar andere contexten. Verpleegkundigen in andere praktijken kunnen zich afvragen hoe de beschreven morele ervaringen zich verhouden tot die van henzelf. Verpleegkundige ethici kunnen de bevindingen in het boek gebruiken om onderwerpen vast te stellen voor verder empirisch en filosofisch onderzoek naar morele ervaringen van verpleegkundigen op de werkvloer.

\section{ONTWIKKELINGEN BINNEN DE VERPLEEGKUNDE}

Aanleiding tot dit onderzoek was de constatering van verschillende auteurs' dat gebrek aan ruimte om goede zorg te geven ertoe kan bijdragen dat verpleegkundigen gefrustreerd en gestresst raken of zelfs burn-out oplopen, omdat ze niet die zorg kunnen geven die ze zouden willen geven. Tot besluit van dit boek wordt teruggegrepen op deze aanleiding. Er wordt ingegaan op de vraag waar en wanneer het van belang is rekening te houden met opvattingen van verpleegkundigen over goede zorg.

\section{Professionalisering}

Tegenwoordig worden door een aantal auteurs binnen de verpleging en verzorging de opvattingen over professionaliteit bestudeerd vanuit de veronderstelling dat gangbare opvattingen te kort schieten. De aandacht wordt daarin volgens deze auteurs te veel gevestigd op methodisering, standaardisering, protocollering en uniformering van het verpleegkundig werk op basis van wetenschappelijk onderzoek. Doel van het gangbare professionaliteitsstreven is zorg inzichtelijk te maken, zodat ze gecontroleerd, beheerst en verbeterd kan worden, terwijl daarbij de morele dimensie van zorg wordt gemarginaliseerd. Gastmans (1998; Gastmans et al. 1998) zegt hierover bijvoorbeeld dat, zonder afbreuk te doen aan pogingen om verplegen te professionaliseren en technologiseren, verplegen daar niet toe kan worden gereduceerd. In specifieke zorgrelaties heeft men volgens Gastmans spontane a.andacht en menselijkheid nodig. Dit is waarom verplegen vraagt om een combinatie van technische vaardigheden en een morele oriëntatie, waarbij verpleegkundigen betrokken zijn bij het welzijn van patiënten.

In pogingen de morele dimensie van zorg aan opvattingen over professionaliteit toe te voegen wordt gesproken over een 'hand-hoofd-hart' concept.' 
Dit concept breekt met de dominante opvatting van professionaliteit, waarin zorg wordt gereduceerd tot het hoofd-aspect (denken, kennen en redeneren) en/of hand-aspect (technisch handelen). Er wordt voorgesteld deze opvatting van zorg te verenigen met het hart-aspect, waarmee menselijke betrokkenheid bij de zorgontvanger wordt uitgedrukt. Indien het hart-aspect in het professioneel handelen is ingebed staat dit niet meer haaks op professionalisering, maar maakt er onlosmakelijk deel vanuit.

Vanuit de analyse van morele ervaringen van verpleegkundigen die in de empirische hoofdstukken is beschreven, kunnen de pogingen om alternatieve opvattingen van professionaliteit te ontwikkelen worden onderschreven. Daar zijn verschillende redenen voor te geven, die tevens duidelijk maken dat het van belang is verder te expliciteren wat het hart-aspect van de zorg inhoudt.

Op de eerste plaats kan het hart-aspect gebruikt worden om te beschrijven wat verplegenden en verzorgenden waardevol vinden in de zorg. Uit dit onderzoek komt naar voren dat verpleegkundigen het belangrijk vinden aandacht te hebben voor het draaglijker maken van het bestaan van patiënten. Deze opvatting van goede zorg kan verbonden worden met het hart-aspect van de zorg. In opvattingen over professioneel zorgverlenen zou deze gerichtheid op het goede verdisconteerd moeten worden. Professioneel zorgverlenen betekent dan niet alleen dat zorg technisch adequaat wordt uitgevoerd volgens wetenschappelijke standaarden, maar ook dat bij het uitvoeren van die zorg rekening wordt gehouden met het draaglijker maken van de situatie voor patiënten.

Op de tweede plaats kan het hart-aspect worden gebruikt om de betrokkenheid van verplegenden bij patiënten tot uitdrukking te brengen. Uit dit onderzoek blijkt dat betrokken raken bij patiënten een voorwaarde is voor goede zorg. De situatie voor patiënten draaglijker maken kan niet zonder daarbij betrokken te raken. Dat is het geval omdat patiënten op afdeling ro, die behandeld worden en opgenomen zijn voor een ziekte, met een type problemen geconfronteerd worden dat daarom vraagt. Hierbij is het van belang. aandacht te hebben voor het feit dat verplegenden niet zo zeer gericht hoeven te zijn op essentiële levensvraagstukken, maar vooral op situaties die lastig, pijnlijk of frustrerend zijn voor patiënten. Betrokkenheid is ook nodig om kennis te verzamelen van de fysieke, emotionele en sociale situatie van een patiënt en diens persoon, om adequaat en betekenisvol op zorgbehoeften te kunnen reageren. Hoewel het belang van betrokkenheid bij de zorg vanuit professionele optiek niet wordt ontkend, krijgt deze weinig aandacht. Het gaat vooral om het protocolleren en standaardiseren van zorg op basis van wetenschappelijke kennis. Deze opvattingen van professioneel zorgverlenen leiden ertoe dat standaardpatiënten (uit het protocol) uitgangspunt zijn van het denken in plaats van een specifiek persoon in zijn of haar bijzondere 
omstandigheden. ${ }^{6}$ Bovendien wordt betrokkenheid als voorwaarde voor zorg nauwelijks uitgewerkt in het professionaliseringsdenken. Als er al aandacht is voor betrokkenheid wordt meestal de waarschuwende vinger geheven. Betrokkenheid kan ertoe leiden dat sommige patiënten worden voorgetrok. ken, dat patiënten niet die zorg krijgen die ze nodig hebben of dat verpleeg. kundigen als persoon het werk niet vol kunnen houden. Verpleegkundigen op de werkvloer zien betrokkenheid bij patiënten als een belangrijke voorwaarde voor zorg. Omdat deze betrokkenheid in het kader van professioneel zorgverlenen onvoldoende wordt uitgewerkt en bovendien met name de valkuilen van betrokkenheid worden benadrukt, kan bij verpleegkundigen op de werkvloer de indruk ontstaan dat ze iets niet goed doen wanneer ze betrokken raken bij patiënten. Het is daarom van belang aandacht te hebben voor deze betrokkenheid in het kader van professioneel zorgverlenen.

Op de derde plaats kan het hart-aspect van zorg gebruikt worden om de verbondenheid van zorgen en ethiek tot uitdrukking te brengen. Zorgen en ethiek zijn voor verpleegkundigen onlosmakelijk met elkaar verbonden. In het zorgend handelen zelf wordt geprobeerd de situatie voor patiënten draag. lijker te maken. Zorgen en ethiek zijn twee kanten van dezelfde medaille, die daarom ook in samenhang met elkaar bestudeerd en ontwikkeld zouden moeten worden. Hierbij is het van belang om bij de verdere uitwerking van opvattingen over professionaliteit het hart-aspect niet slechts op te vatten als een kwestie van betrokkenheid bij patiënten, als een fatsoenlijke bejegening of een respectvolle houding. Uit dit onderzoek komt namelijk naar voren dat dit weliswaar van belang is, maar dat verpleegkundigen veel meer doen om het bestaan van patiënten draaglijker te maken. Verpleegkundigen verrichten daarvoor ook allerlei technische en praktische activiteiten. Het ethische is onlosmakelijk verbonden met technisch en zorgend handelen. Uit dit onderzoek komt naar voren dat ethiek als het ware ook het 'hart', van het hoofd-en hand-aspect van de zorg is. Wanneer de symboliek van 'hand-hoofd-hart' gebruikt wordt om opvattingen van professionaliteit verder te ontwikkelen, is het van belang ervoor te waken dat het hart-aspect niet tot een houding van zorgverleners wordt gereduceerd. Dit hart-aspect zou verder kunnen worden uitgewerkt rondom de vraag hoe in het zorgend handelen zelf de situatie voor patiènten draaglijker gemaakt kan worden. Welke zorgactiviteiten kunnen verpleegkundigen verrichten om de situatie voor patiënten draaglijker te maken? Hoe kunnen ze rekening houden met gevoelens, emoties en ervaringen van patiënten bij het uitvoeren van verzorgende en technische handelingen?

De vraag wat het betekent om professioneel verantwoorde zorg te geven, kan niet teruggebracht worden tot het beschrijven van een wetenschappelijk verantwoorde aanpak, omdat voor verpleegkundigen de vraag hoe de situatie voor patiënten draaglijker gemaakt kan worden hier onlosmakelijk mee ver- 
bonden is. Vanuit dit onderzoek wordt er daarom voor gepleit meer aandacht te besteden aan het hart-aspect van de zorg. Hierdoor komt erkenning voor morele oriëntaties van verpleegkundigen op de werkvloer en kan ruimte worden gecreëerd deze in de dagelijkse zorg tot uitdrukking te brengen.

\section{Inzicht in opvattingen van goede zorg}

Verpleegkundigen zijn erop gericht de situatie voor patiënten zo draaglijk mogelijk te maken. Verpleegkundigen hebben daarmee een eigen morcle oriëntatie in de zorg. Inzicht in deze opvattingen van goede zorg kan tot gevolg hebben dat verpleegkundigen zich zelf meer bewust worden van hun specifieke bijdrage aan de zorg voor patiënten binnen de gezondheidszorg. Hierdoor kan hun gevoel van eigenwaarde worden versterkt en zijn ze misschien beter in staat zich te profileren ten opzichte van andere zorgverleners.

Een andere reden waarom inzicht in gehanteerde opvattingen van goede zorg van belang is voor de kwaliteit van patiëntenzorg, is dat deze een rol kunnen spelen bij meningsverschillen tussen verpleegkundigen onderling of met andere zorgverleners over de vraag wat goed is om te doen voor een patiënt. Soms leiden meningsverschillen tot ernstige conflicten waarin betrokkenen lijnrecht tegenover elkaar komen te staan. Dit verschil van mening is soms terug te voeren op verschillende waarden die betrokkenen hanteren in de zorg. Omdat deze zich daarvan niet altijd bewust zijn, kan dit leiden tot discussie. Dat heeft niet alleen een negatieve invloed op de verhoudingen tussen zorgverleners onderling, maar ook op de kwaliteit van zorg voor patiënten. Meningsverschillen kunnen ertoe leiden dat er geen betekenisvol en adequaat antwoord gevonden wordt op een zorgbehoefte van een patiënt. Verpleegkundigen en andere zorgverleners zijn zich vaak onvoldoende bewust van de werking van hun opvattingen van goede zorg. Inzicht daarin, zo wordt op basis van dit onderzoek verondersteld, zou eraan bij kunnen dragen dat meningsverschillen adequater worden gehanteerd, zodat ze niet leiden tot verslechterde verhoudingen of tot zorg van onvoldoende kwaliteit voor patiënten. Tegenwoordig wordt moreel beraad gezien als een manier om verpleegkundigen en andere werkers binnen de gezondheidszorg te ondersteunen bij morele reflectie op hun eigen handelen.

Inzicht in opvattingen van goede zorg is daamaast nog op een andere manier van belang in het kader van de kwaliteit van zorg voor patiënten. Deze kunnen er namelijk toe bijdragen dat zorgbehoeften worden gesignaleerd. Verpleegkundigen zien een behoefte aan zorg, omdat hun aandacht daamaar uitgaat. Ze zien iets omdat ze het waardevol vinden in het kader van goede zorg voor patiënten. Opvattingen van goede zorg kunnen het signaleren van zorgbehoeften echter ook belemmeren. Zorgbehoeften worden minder snel 
gezien of zelfs genegeerd, als verpleegkundige iets niet waardevol vinden in de zorg. Door morele ervaringen van verpleegkundigen te bestuderen, kan het 'morele gezicht' van een afdeling zichtbaar worden. Waar staan verpleeg. kundigen voor in het kader van de zorg en welke consequenties heeft dat voor patiënten? Aan welke zorgbehoeften wordt eerder tegemoet gekomen dan aan andere? Welke zorgbehoeften dreigen daardoor minder aandacht te krijgen? In de empirische hoofdstukken is het morele gezicht van afdeling ro zichtbaar geworden. Wanneer een 'moreel gezicht' niet zichtbaar is en niet wordt besproken kan dit ongemerkt haar werk doen. Zichtbaar maken van morele ervaringen van verpleegkundigen is daarom van belang in het kader van kwaliteit van zorg voor patiënten.

\section{Beleid en zorg}

Inzicht in de morele ervaringen van verpleegkundigen kan het denken en handelen van betrokkenen bij het faciliteren van zorg aanscherpen. De bevindingen in dit boek kunnen gebruikt worden bij het organiseren en financieren van de dagelijkse zorg en het ondersteunen van zorgverleners bij het uitvoeren van hun taak.

Beleidsmakers en managers kunnen de bevindingen in dit boek gebruiken om hun concept van goede zorg aan te scherpen. Veronderstelling daarbij is dat beleidsmakers en managers vaak een concept van zorg hanteren waarin effectiviteit en efficiëntie de boventoon voeren, terwijl verpleegkundigen op de werkvloer erop gericht zijn kwaliteit van leven van patiënten te bevorderen: Raken verplegenden en verzorgenden gefrustreerd en gestresst, omdat ze niet die zorg kunnen geven die ze zouden willen geven?

De bevindingen uit dit boek onderstrepen deze veronderstelling. Goede zorg heeft voor verpleegkundigen van afdeling to te maken met het draaglijker maken van de situatie voor patiënten. Het bieden van lichamelijke verzorging of het organiseren van pijnbestrijding zijn geen activiteiten die louter worden uitgevoerd orn de behandeling te ondersteunen, maar hebben ook te maken met het bevorderen van de draaglijkheid van het bestaan van patiënten. Zorg is niet alleen goed als een bepaalde handeling volgens een standaard, protocol of volgens de laatste wetenschappeliike kennis wordt uitgevoerd. Goede zorg bieden kan ook betekenen dat er minder efficiënt gewerkt wordt, maar dat een patiënt wel het gevoel heeft dat er tijd en aandacht voor hem is als dat op een bepaald moment nodig is. Tegelijkertijd ervaren verpleegkundigen de ruimte om goede zorg te geven binnen de context van de afdeling, regelmatig als te beperkt. Hoewel verpleegkundigen erkennen dat dit te maken heeft met de organisatie en financiering van zorg, waar vooral beleidsmakers en managers verantwoordelijk voor zijn, ervaren ze dat vaak toch als een 
moreel probleem, omdat zij aan specifieke patiënten die dat van hen vragen niet die zorg kunnen geven die nodig is om de situatie draaglijker te maken.

Op basis van dergelijke bevindingen wordt er in dit boek voor gepleit dat beleidsmakers en managers opvattingen van verpleegkundigen, verplegenden en verzorgenden over goede zorg betrekken bij het organiseren en financieren van zorg. Het is geen pleidooi om effectiviteit, efficiëntie of 'evidenced based practice' af te schaffen, maar om dit aan te vullen met het denken in termen van het draaglijker maken van de situatie van patiënten vanuit een houding van betrokkenheid en verantwoordelijkheid. Dat is van belang voor verpleegkundigen, omdat ze dan aspecten van de zorg die zij als waardevol ervaren terug kunnen vinden in het organiseren en financieren van de zorg. Ook de kwaliteit van zorg voor patiënten kan hierdoor verbeteren.

Op basis van dit onderzoek wordt geconcludeerd dat verpleegkundigen een eigen morele oriëntatie hebben. Deze dient betrokken te worden bij het denken over zorg binnen een organisatie. Dat betekent wel dat er naar verplegenden en verzorgenden geluisterd moet worden. Echter, door de huidige tendens instellingen meer horizontaal rondom patiëntenzorg te organiseren, de zogenaamde kanteling van de organisatie, is het gevaar aanwezig dat de kloof tussen beleidsmakers en verplegenden en verzorgenden op de werkvloer toeneemt. Steeds minder vaak maken vertegenwoordigers van de verpleegkundige beroepsgroep deel uit van het hoger management, terwijl de economische en medisch specialistische vertegenwoordiging op volle sterkte blijft. In veel grote instellingen verdwijnen bijvoorbeeld verpleegkundig directeuren, adjunct directeuren zorg of hoofden verplegingsdienst. Zij worden vervangen door geneeskundige en financiële managers. Volgens Hilmann (200Ia, b) is dat wellicht de reden dat in de missie van de moderne instellingen meestal geen visie op zorg is terug te vinden. De AVvV (koepel organisatie van verpleging en verzorging) stimuleert het instellen van VAR's (Verpleegkundige Advies Raden) om daarmee de invloed van verplegenden op instellingsbeleid te vergroten. Concreet kan de bijdrage van een VAR bijvoorbeeld bestaan uit advisering bij beddensluiting, waarbij de adviesraad criteria voor kwaliteitsbehoud aangeeft. Ook kan de VAR van nut zijn bij het organiseren van themamiddagen over beroepsinhoudelijke zaken als ethiek of tuchtrecht (Schumacher 1997). Vanuit verpleegkundige beroepsorganisaties wordt gezocht naar ruimte waarin verplegenden hun opvattingen van goede zorg kunnen laten horen, binnen de instellingen waarin zij werkzaam zị̣n. Dit zou ertoe kunnen leiden dat hiermee invloed wordt uitgeoefend op het beleid van zorginstellingen en dat er meer aandacht en ruimte komt voor opvattingen van verplegenden en verzorgenden van goede zorg, waardoor ze zich beter herkennen in de manier waarop zorg is georganiseerd. Het blijft echter de vraag of verplegenden en verzorgenden, die een grote belangen- 
partij zijn in de zorg, niet op een vergelijkbare manier vertegenwoordigd zouden moeten zijn als bijvoorbeeld medisch specialisten.

Inzicht in morele ervaringen van verplegenden en verzorgenden zou bij beleidsmakers en managers ertoe kunnen leiden dat ze opvattingen van verplegenden en verzorgenden meer betrekken bij het organiseren en financieren van zorg. Verplegenden en verzorgenden herkennen zich daardoor beter in het beleid en ondervinden meer ruimte om de zorg te geven die zij als goed ervaren. Daarnaast kan dit inzicht er ook toe leiden dat er aandacht komt voor de vraag wat verplegenden en verzorgenden zelf nodig hebben om goede zorg te geven. Zoals in de empirische hoofdstukken is aangetoond speelt betrokkenheid bij patiënten een belangrijke rol in het denken en handelen van verpleegkundigen. Om deze betrokkenheid te hanteren is het nodig om voor verpleegkundigen ruimte te scheppen hun emoties te uiten en te verwoorden. Bovendien blijken verpleegkundigen ondersteuning nodig te hebben in de vorm van feedback en waardering. Zorgverleners hebben zorg voor zichzelf nodig om goede zorg te kunnen verlenen. Volgens Blanc (1998) is het van belang:

“... zorgverleners de mogelijkheid te bieden om over de emotioneel belastende ervaringen in relatie met patiënten te spreken met collega's, bijvoorbeeld door middel van vaste intervisie-bijeenkomsten. Dit kan helpen om de negatieve effecten van dit type belasting op het welzijn van zorgverleners te verminderen. De organisatie zou hierbij een faciliterende rol kunnen vervullen, door tijd en geld beschikbaar te stellen voor dit type bijeenkomsten: gezonde werknemers vormen immers de basis voor het goed functioneren van de organisatie" (p.r3).

Wanneer wordt erkend dat zorgen voor een ander te maken heeft met relationaliteit, waarbij een verpleegkundige als persoon betrokken moet zijn, is het bieden van gepaste begeleiding en ondersteuning van belang. Meer zorg voor verplegenden en verzorgenden zelf, bijvoorbeeld in de vorm van intervisie, supervisie, functioneringsgesprekken, voortgangsgesprekken of moreel beraad, is nodig om het soort werk dat ze verrichten op de langere termijn vol te kunnen houden. Daarnaast is het ook een voorwaarde om de rol die verplegenden en verzorgenden vervullen optimaal uit te kunnen voeren. Wanneer zij zelf het 'relationele instrument' zijn om de situatie voor patiënten zo draaglijk mogelijk te maken, dan moet er ruimte zijn voor het uiten van emoties en zal de eigen rol steeds weer opnieuw overdacht en geëvalueerd moeten worden. 


\section{NOTEN}

\section{Hoofdstuk I}

I Stelt bijvoorbeeld Hoorebeke (2000).

2 Stelt bijvoorbeeld Koopman (200r).

3 Concluderen een aantal auteurs (Calsbeek et al. 2000; Calsbeek et al. 1998; Hoorebeke 2000; Koopman 200I).

4 Zie Calsbeek et al. (1998, 2000).

5 Stellen bijvoorbeeld Blanc et al. (1998).

6 Concluderen bijvoorbeeld Blanc et al. (1998).

7 Stellen een aantal auteurs (Dartel 1999a; Dartel r999b; Hillmann \& Most 20orb; Kruijswijk Jansen 2000).

8 Hoewel het voorafgaande van toepassing is op verplegenden (niveau 4 en 5 ) en verzorgenden (niveau 3 ) in het algemeen, richt dit onderzoek zich op verpleegkundigen (niveau $4+5$ ). In hoofdstuk 3 wordt de keuze dit onderzoek te richten op morele ervaringen van verpleegkundigen van een hematologie oncologie afdeling van een algemeen ziekenhuis gemotiveerd.

9 In hoofdstuk 2 wordt de keuze voor de terminologie beargumenteerd, die gebruikt wordt om verschillende stromingen in verpleegkundige ethiek te onderscheiden.

Io Voor een dergelijke opvatting van kwalitatief onderzoek zie bijvoorbeeld Maso \&. Smaling (1998).

II Voor een dergeliịke stelling zie bijvoorbeeld Lange et al. (I999).

12 Tegenwoordig wordt steeds meer kwalitatief onderzoek binnen de gezondheidszorg verricht (Gremmen I995b; Mesman 2002; Pool 1996; Thé 1997).

I3 Voor een dergelijke opvatting met betrekking tot het zichtbaar maken van morele ervaringen zie ook Gremmen (1995b).

\section{Hoofdstuk 2}

I In verpleegkundige literatuur worden de termen 'deugdethiek' en 'zorgethiek' ofwel 'virtue ethics' en 'ethics of care' meestal door elkaar gebruikt. In dit proefschrift worden ze van elkaar onderscheiden. Belangrijk onderscheidingscriterium daarbij is de vraag in hoeverre er aandacht is voor dagelijkse morele ervaringen van verpleegkundigen op de werkvloer, omdat in dit hoofdstuk gezocht wordt naar een theoretisch kader om morele ervaringen van verpleegkundigen met dagelijkse zorgverlening inzichtelijk te maken. In het kader van verpleegkundige deugdethiek (paragraaf 2) wordt daarom het accent gelegd op dat deel van de verpleegkundige literatuur dat deugden voor goede zorgverlening zoekt in historische of 
filosofische studies van het concept 'goede zorg'. In paragraaf 3 (zorgethiek) wordt ingegaan op dat deel van de literatuur dat de activiteit van het dagelijks zorgverlenen centraal stelt. Auteurs die in beide paragrafen aan de orde komen, kunnen zichzelf anders benoemen. Auteurs die bijvoorbeeld onder de noemer van deugdethiek aan de orde komen kunnen, scharen zichzelf onder de zorgethiek en omgekeerd.

2 In het werk van Beauchamp en Childress (1979) is de toon gezet om waarden en normen die een centrale rol spelen in de gezondheidszorg samen te vatten in vier ethische principes.

3 Dit geldt bijvoorbeeld voor de volgende publicaties op het vlak van verpleegkundige ethiek: (Bandman \& Bandman 1985; Curtin \& Flaherty 1982; Fitzpatrick 1988; Husted \& Husted 199r; Thompson \& Thompson r98r). Ter ondersteuning van deze conclusie worden enkele van voornoemde auteurs geciteerd. Bandman en Bandman (1985) geven een "developmental framework for the application of relevant ethical principles ... (p. xi). Ze benadrukken rechten van patiënten. "Rights in health care are individual passports, permits and licenses to acceptable health care standards which promote maximal self-determination and well-being $(p$. xi). Curtin en Flaherty $(1982)$ benadrukken bijvoorbeeld dat "... recognition and respect of the rights of others-patient or clients, families, nurses, physicians - and the use of logical reasoning in addressing issues and conflicts in relationships between the nurse and recipients of care and in intraprofessional relationships" (p.xii) Fitzpatric (1988) stelt dat: "Whereas general ethics is a particular part of philosophy, nursing ethics is a type of applied ethics, in which the principles and argumentative techniques built up in general ethics are applied to particular problems raised by nursing practice" (p. 55). Husted en Husted (r99x): "The book sets out an ethical decision-making model based on a contextual application of the bioethical standards. The model is structured to help nurses to make contextually appropriate (justifiable) ethical decisions" (p. xi). "A professional ethic that does not put reason at its center is not different from that of the man in the street, it would not, in any relevant sense, be a professional ethic ${ }^{\circ}$ (p. ix).

4 Dit concludeert Kañne (ig94) voor de twee, volgens haar in het Nederlands onderwijs meest gebruikte ethische handboeken, namelijk Kamphuis \& Morisson (i988) en Rijkse \& Vestjes (1991). Een dergelijke conclusie geldt eveneens voor een aantal andere athische handboeken binnen de verpleging (Arend I988; Manenschijn I984; Manneke 1990; Meykamp et al. 1992: Rijksen \& Aarts 1993; Tenwolde 1993. $19198)$.

5 Zis bijvoorbeeld de 'American Nurses Associaton's Code for Nurses with Interpretative Statements'. Deze stelt het volgende: "When making clinical judgments, nurses base their decisions on consideration of consequences and of universal moral principles, both of which prescribe and justify nursing actions. The most fundamental of these principles is respect for persons. Other principles stemming from this basis principle are autonomy (self-determination), beneficence (doing good), non-maleficence (avoiding harm), veracity (truth-telling), confidentiality (respecting privileged information), fidelity (keeping promises), and justice (treating people: fairly). (Nurses Association: Code for Nurses with Interpretive Statements. Kansas City, MO. American Nurses' Association, 1985, p. i.) Voor de conclusie dat beroepscordes gebaseerd zijn op een principe ethisch denkraam, zie ook Fowler (I989). 
Zie bijvoorbeeld het werk van Davis en Aroskar (1978) dat als standaardwerk voor verpleegkundige ethiek geldt of de veel geciteerde publicatie van Thompson. en Thompson uit (I981).

7 Voor een uitwerking van deze kritiek zie bijvoorbeeld Melia (1994).

8 In dit hoofdstuk wordt het werk van Tenwolde uit 1998 gebruikt om het toegepast filosofische karakter van verpleegkundige ethiek verder te verhelderen. Voor deze publicatie is gekozen omdat deze toen dit hoofdstuk geschreven werd de meest recente was in het kader van verpleegkundige principe-ethiek in Nederland. Dit werk is echter paradigmatisch voor andere publicaties op dit terrein (zie noot 2,3,4).

9 Zie bijvoorbeeld De Beaufort \& Dupuis (1988) of Van Willigenburg et al. (1993).

Io Stellen o.a. Van Houten \& Van Lieshout (1994).

II In het kader van ethiek worden meerdere opvattingen van autonomie overdacht. Dat zal bijvoorbeeld zichtbaar worden in paragraaf 3, waar zorgethiek wordt besproken. Binnen medische en gezondheidsethiek is echter één opvatting dominant. 'Respect voor autonomie' wordt opgevat als het beschermen van het recht zelfbeschikking van mensen (Lelie 1999; Schermer 200r; Widdershoven 2000).

12 Vanaf 1984 als richtlijn en vanaf 1995 als wet.

13 Zie bijvoorbeeld Ebskamp \& Kroon (1993), Rijksen \& Aarts (1993) of Tenwolde (I998).

14 In Amerikaanse handboeken wordt nog sterker de nadruk gelegd op autonomie van patiënten als zelfbeschikkingsrecht. Wellicht als gevolg van de verregaande juridisering van de gezondheidszorg.

15 Bijvoorbeeld in de volgende handboeken: (Bandman \& Bandman 1985; Curtin \& Flaherty 1982; Davis \& Aroskar 1978; Ebskamp \& Kroon 1993; Fitzpatrick i988; Manenschijn 1984; Manneke 1990; Meykamp et al. 1992; Rijksen \& Aarts 1993; Rijksen \& Aarts 199r; Tenwolde 1995, 1998; Thompson \& Thompson 198r, 1983; Van den Hoven $\&$ Tenwolde ig88).

16 Concluderen ook Arend \& Gastmans (1993).

17 Ethische besluitworming in vier stappen (Tenwolde 1998: 97):

Stap I: het probleem identificeren

- Kort beschrijven van de situatie en de ethische vraag.

- Overzicht krijgen van de relevante informatie.

Stap 2: het probleem analyseren

- Benoemen van de waarden en belangen van de betrokken personen.

- Eventuele tegenstellingen benoemen.

- Vaststellen wie de beslissingen moet(en) nemen.

- Opnieuw benoemen van de ethische vraag.

Stap 3: besluiten ontwikkelen

- Mogelijke gedragslijnen en hun gevolgen inventariseren en uitwerken.

Stap 4: een keuze maken

- Gedragslijnen afwegen en toetsen.

- Een gedragslijn kiezen.

- Bijbehorende uitvoeringsbesluiten nemen.

I8 Verpleegkundigen moeten zicht krijgen op de diepere verlangens en voorkeuren van patiënten. Om een duidelijker beeld te krijgen van verschillende typen verlangens en voorkeuren van patiënten die van invloed zijn op keuzes die ze maken wordt in verpleegkundig ethisch handboeken ook wel een onderscheid gemaakt 
tussen yoorkeuren van de eerste orde en tweede orde (of niveau). Tenwolde (1998) gebruikt een definitie van Dworkin om dit verder te verhelderen. "Autonomie moet men zich voorstellen als een vermogen van de tweede orde om voorkeuren, verlangens wensen enzovoorts van de eerste orde kritisch te overdenken, en het vermogen om die ofwel te accepteren ofwel te proberen die te veranderen op grond van voorkeuren en wensen van een hogere orde. Door een dergelijk vermogen te benutten, bepalen personen hun karakter, geven ze betekenis en samenhang aan hun leven en nemen ze verantwoordelijkheid voor het soort persoon dat ze zijn. (Dworkin in Tenwolde $1998: 19$ )". Een autonome keuze is een keuze die rekening houdt met voorkeuren en wensen van een hogere orde.

19 Deze kritiek past binnen een bredere beweging die het toegepaste karakter van de principe ethiek bekritiseert (Bauman 1993; Ten Have 1998; Nussbaum 1986; Taylor 1994; Van Tongeren 1997: De Vries 1993; Williams 1985).

20 Verschillende auteurs uit het Angelsaksische taalgebied laten zich onderbrengen onder de noemer van verpleegkundige deugdethiek, zoals die binnen deze studie wordt gehanteerd (Brody 1988; Crowden 1994; Crowley 1989, 1994; Davis 1995; Fry 1989; Gadow 1983; Leininger 1981; Melia 1994; Olsen 1992; Omery 1989, Pellegrino \& Thomasma 1988; Scott 1998; Sellman 1997; Watson 1992).

21 Verschillende auteurs uit de Scandinavische landen laten zich onderbrengen onder de noemer van verpleegkundige deugdethiek, zoals die binnen deze studie wordt gehanteerd (Astrom et al. I993; Lutzen 1997; Nortvedt 1998; Sarmivaki 1995).

22 Zie bijvoorbeeld Gastmans, (1995a, b, c), Gastmans (1996). Gastmans et al. (1998).

23 Het werk van verschillende auteurs kan daarom zowel in deze als in de volgende paragraaf aan de orde komen (Bishop \& Scudder 1999; Cooper 199r; Gastmans 2000; Parker 1990; Salsberry 1992). Deze auteurs worden in deze paragraaf besproken onder de noemer van deugdethiek, wanneer zij opvattingen formuleren die passen bij de definitie van verpleegkundige deugdethiek die in deze paragraaf wordt gehanteerd. Ze komen echter ook in de volgende paragraaf aan de orde. In hun werk zijn namelijk ook opvattingen terug te vinden die passen onder de noemer van zorgethiek, die zorg als praktijk opvat.

24. Stellen een aantal auteurs (Gadow 1988; Pellegrino \& Thomasma 1988; Watson 1985).

25 Zie bijwoorbeeld Sellman (1997).

26 Voor een uitwerking van dit argument zie bijvoorbeeld Salsberry (1992).

27 Vanuit de principe-ethiek wordt door verschillende auteurs kritiek geuit op de verpleegkundige deugdethiek (Allmark 1995a, b, 1998; Crigger 1997; Curzer I993a, b; Kuhse 1995).

28 Bijwoorbeeld Tronto (1993) en Sevenhuijsen (1996) verzetten zich een opvatting van zorgen, waarbij dit alleen als deugd wordt opgevat. Zorgen wordt door deze auteurs daarom benoemd als activiteit.

29 Er zijn verschillende ethici binnen de verpleging die zorg vooral als praktijk opvatten (Benner 1991; Cooper 1991; Gastmans \& Casterlé 2000; Lipp r998; Melia 1994; Nortvedt 1998; Omery 1989; Parker 1990).

30 Door een aantal auteurs is binnen feministische literatuur zorgethiek als ethisch perspectief uitgewerkt (Gilligan 1982, 1985; Gremmen 1992, 1995b, 1997; Sevenhuijsen 1996; Sevenhuijsen 1997; Tronto 1993, 1997).

31 Door een aantal auteurs is binnen gez:ondheidsethiek in het algemeen zorgethiek als nieuw ethisch perspectief uitgewerkt (Manschot r997; Manschot \& Verkerk 
1994; Termeulen 1994; Verkerk 1994, 1997a, b. 200I; Widdershoven 1995, 2000: Widdershoven \& Smits r996; Widdershoven, 1999b).

32 Volgens zorgpraktijk ethici zijn deze aspecten niet met het mens zijn gegeven, maar resultaut van een specifiek zoekproces. Beargumenteerd werd dat juist dit beeld van een mens zichtbaar is geworden omdat enerzijds vooral een bepaalde groep mensen zich heeft bezig gehouden met het zoeken naar een algemeen antwoord op de vraag 'hoe wij mensen met elkaar moeten omgaan', namelijk in goeden doen verkerende blanke mannelijke ethici. En anderzijds, zo was vanuit kritisch feministische hoek te horen, is dit mensbeeld het resultaat van een keuze voor specifiek onderzoeksonderwerp, namelijk: blanke in goede doen verkerende mannen, opererend in de publieke sfeer. Een model van een mens dat in dit proces werd gecreëerd, werd vervolgens als universeel omschreven (Calhoun I988; Gilligan 1982; Mendus 1993; Verkerk 1994). Ervaringen van een specifieke groep mensen is het paradigma geworden voor alle mensen. Ervaringen van anderen, bijvoorbeeld de ervaringen van vrouwen die vaak zorgen in de privé sfeer, mensen die in armoede verkeren of etnische minderheden, verdwijnen hiermee van het toneel.

33 Voor een uitwerking van deze veronderstelling zie bijvoorbeeld Carse (1988). Deze auteur zet principe-ethiek en zorgethiek tegenover elkaar aan de hand van de vraag welke morele kwesties hierin aan de orde kunnen komen. Zie ook Little (1998).

34 Kwesties als deze worden ook benoemd door Benner et al. (I992).

35 Het concept 'vertrouwen' wordt in zorgethiek op basis van het werk van Baier $(1989,1993,1994)$ uitgewerkt.

36 Het concept 'verantwoordelijkheid' is bij̣oorbeeld uitgewerkt in het werk van Walker (1997).

37 Door Tronto (1993) is zorgen als raamwerk uitgewerkt om kwesties van macht en verantwoordelijkheid aan het licht te brengen.

38 Door Tronto (1993) wordt zorgen neergezet als een concept dat het denken binnen ethiek en politiek kan verrijken.

39 Zie voor een uitwerking van deze opvatting binnen de verpleging bijvoorbeeld Salsberry (1992).

40 Voor een uitwerking van autonomie als authenticiteit zie het werk van Meyers (1987, 1993).

$4^{1}$ Voor een uitwerking van autonomie in relatie tot identiteit en integriteit zie Keller (1997) en Sevenhuijsen (1996).

42 Voor een uitwerking van deze opvatting zie Meyers (1987).

43 Voor een uitwerking van deze opvatting zie Keller (i997).

44 Zie bijvoorbeeld Keller (1997).

45 Voor een uitwerking van het concept 'verantwoordelijkheid' zie Walker (1997).

46 Zie bijvoorbeeld Tronto (r993).

47 Zie bijvoorbeeld Verkerk (1997 a, b).

48 Zie bijvoorbeeld Sevenhuijsen, 1996).

49 Zie bijvoorbeeld Verkerk (2001).

50 Zie bijvoorbeeld Baier (1989).

SI Zie bijvoorbeeld Sevenhuijsen (1996).

52 In haar aandacht voor gesitueerdheid van mensen is zichtbaar dat een zorgethiek haar wortels heeft in een feministische onderzoekstraditie, die aandacht heeft voor kwesties van in- en uitsluiting. In deze traditie wordt beargumenteerd dat, door het 
zoeken naar wat mensen met elkaar gemeen hebben, er 'wij' en 'zij' categorieën worden geconstrueerd, waarbij vervolgens de 'zij' categorie als anders wordt aangeduid en gewaardeerd. Verondersteld wordt dat, bij de gratie van wat mensen met elkaar gemeen hebben - al is het nog zoiets nastrevenswaardigs als in vrijheid kunnen leven - vervolgens anderen als afwijkend worden beschouwd en buitengesloten. In eerste instantie was daarbij vooral aandacht voor de manier waarop vrouwen werden buitengesloten van een publiek domein, door hen als categorie mensen aan te duiden die over allerlei eigenschappen beschikken om te zorgen in de privé sfeer. Later wordt ook aandacht besteed aan uitsluiting van andere geconstrueerde groepen, zoals mannen, minderheden, gehandicapten, leeftijd, etc. Daarom wordt tegenwoordig meestal niet meer gesproken over vrouwenstudies, en ook niet meer over genderstudies (waarin het ging over categorieën vrouwen én mannen) maar over diversiteit. Om 'wij' en 'zij' vorming zo veel mogelijk te voorkomen en daarmee kwesties van in- en uitsluiting stelt een zorgethiek voor gesitueerde en geparticulariseerde anderen als uitgangspunt te nemen voor ethische reflectief.

53 Stelt bijvoorbeeld Carse (1998).

54 Stelt bijvoorbeeld Waerness (1990).

55 Dat geldt voor een aantal auteurs binnen de verpleging (Benner 199r; Benner \& Tanner 1987; Bishop \& Scudder 1990; Carper 1978; Nortvedt 1998; Sarvimaki 1995).

56 Zie bijvoorbeeld Benner \& Wrubel (1998).

57 Zie bijvoorbeeld het werk van Code (1990, 1995).

\section{Hoofdstuk 3}

I In dit onderzoek wordt aangesloten bij de specifieke opvatting van Maso en Smaling (1998) over de verhouding tussen theoretische uitgangspunten en dataverzameling, namelijk de abductieve redeneerwijze (p. 30 e.v.). Hierbij wordt ervan uitgegaan dat theoretische uitgangspunten nodig zijn om gegevens te verzamelen, maar kunnen deze uitgangspunten tegelijkertijd vanuit de dataverzameling verder worden uitgewerkt, aangescherpt of verworpen. In hoofdstuk 8 van dit proefschrift wordt de bruikbaarheid van zorgethiek voor het bespreken van morele ervaringen van verpleegkundigen met dagelijkse zorgverlening vanuit het empirische materiaal opnieuw besproken.

2 Voor een dergelijke opvatting over de invloed van de institutionele context zie bijvoorbeeld Lagae \& Verschueren (2000) in verpleegkundige literatuur en Sevenhuijsen (1996) in feministische zorgethische literatuur.

3 Dit onderzoek kan ook als een etnografische studie worden benoemd, wanneer het begrip 'etnografie' als synoniem voor 'veldwerk' wordt gebruikt. Ik vermijd de term hier echter, omdat het begrip 'etnografie' binnen kwalitatieve studies niet eenduidig wordt gebruikt. Voor een overzicht van verschillende opvattingen over etnografisch onderzoek binnen sociologisch onderzoek en ethisch onderzoek zie Mesman (1989: i68 noot 24).

4 Om de participerende observatie vorm te geven is gebruik gemaakt van het werk van Hammersley \& Atkinson ( 1983 ).

5 In de periode van 1982 tot 1986 heb ik zelf deze opleiding gevolgd. In die tijd was het gebruikelijk dat studenten in de eerste twee jaren van hun opleiding aan de praktijk 
gingen 'snuffelen' om ermee kennis te maken. Gedurende twee weken werd je gekoppeld aan een verpleegkundige. Deze nam je mee, liet alles zien en beantwoordde vragen. Bovendien mocht je - indien dat gangbaar was binnen die setting een uniform aan en allerlei eenvoudige handelingen verrichten, zoals bedden opmaken. Deze rol was uitstekend geschikt om participerende observaties uit te voeren.

\section{Hoofdstuk 7}

Dergelijke zorgactiviteiten worden in het kader van oncologieverpleging met name besproken onder de noemer van psychosociale problematiek en niet onder de noemer van ethiek (Cohen et al. 1994; Delvecchio Good et al. 1990; Essen et al. 1995; Fliedner r997; Fliedner 1994) (Riekwel 1996; Radwin 2000; Radwin \& Alster I999; Pasch 2000). Veluw (1997) gaat bijvoorbeeld expliciet in op het thema dat patiënten gestimuleerd moeten worden hun verhaal te vertellen. Daarnaast is ook aandacht voor problematiek die expliciet samenhangt met geïsoleerd verpleegd worden (Carnpell 1999) of tijdsbesteding van patiënten (Courtens et al. 1998). De onderwerpen die in dergelijke literatuur worden besproken vertonen overeenkomsten met datgene wat ik in hoofdstuk 4 beschrijf. Ze worden echter niet in verband gebracht met ethiek.

In ethische literatuur over oncologie verpleging komen de onderwerpen die ik in hoofdstuk 4 beschrijf minder aan de orde. Behalve als het gaat om het informeren van patiënten of privacy. Ethische literatuur over oncologie verpleging is met name vanuit toegepast perspectief geschreven en gaat bijvoorbeeld over: autonomie, informed consent, recht op informatie, waarheid vertellen, doorbehandelen, stoppen met therapie, grenzen tussen curatieve behandeling en palliatieven zorg, euthanasie, hulp bij zelfdoding, einde van het leven beslissingen (Allison \& Ewens 1998; Barnes et al. 1998; Cain 1998; Ersek et al. r995; Kuuppelomaki 1998; Lievaart 1999: Thomasma 1992; Willems-Cavalli 1997). In dergelijke artikelen is veelal ook aandacht voor pijnmanagement. Dat heeft niet die inhoud zoals ik dat in hoofdstuk 4 heb beschreven maar wordt meestal in verband gebracht met beslissingen rondom het levenseinde.

2 Zie bijvoorbeeld Sevenhuijsen (1996) en Tronto (r993).

3 In tegenstelling tot bijvoorbeeld het praktijkbegrip van Maclntyre, waarin doelen van buitenaf gegeven lijken. Voor deze opvatting van het praktijkbegrip van MacIntyre zie Sevenhuijsen (1996).

4 Voor een uitwerking van kwalitatief onderzoek binnen zorgethiek zie Widdershoven (1999a).

5 Zie bijvoorbeeld Benner (1991), Cooper (I991), Parker (1990), Salsberry (1992).

6 Mesman (2002: 63) concludeert dat onzekerheid ook een karakteristiek element is van de medische praktijk. $\mathrm{Zij}$ verwijst naar verschillende medisch sociologische studies over het thema 'onzekerheid bij artsen' (Mesman 2002: 176 noot I).

7 Bij dat punt is in hoofdstuk 5 ook beschreven dat verpleegkundigen soms vragen van patiënten negeren uit angst voor emoties. Een dergelijke bevinding komt ook naar voren uit een studie van Brunklaus (2000). Deze auteur constateert een spanningsveld tussen onbevangen naar patiënten kunnen luisteren en de eigen angst voor de eigen machteloosheid als je te zeer betrokken raakt. 
8 Stellen een aantal auteurs (Fisher \& Tronto I99I; Sevenhuijsen 1996; Waerness i990).

9 Zie bijvoorbeeld Wearness (I990).

Io Zie bijvoorbeeld Heitman \& Roberson (1997) of Nuy et al. (2000).

II Volgens Meinen (1993) "lijken keuzes in de zorg voor verpleegkundigen voornamelijk te gaan " ... over weinig en nog minder" (p.25).

12 Zie bijvoorbeeld Verkerk (1998, r999).

13 Uitzondering daarop is bijvoorbeeld Parker (1990). Deze auteur spreekt over co-construction of meaning. $\mathrm{Zij}$ gaat er vanuit dat verpleegkundigen invloed hebben op de nieuwe invulling die patiënten samen met verpleegkundigen zoeken in hun leven.

I4 Volgens Schermer (200I) is het niet de taak van verpleegkundigen zich op een dergelijke manier met het leven van patiënten te bemoeien. Een dergelijke opvatting is moeilijk houdbaar binnen de dagelijkse zorg. Verpleegkundigen worden nu eenmaal met dergelijke vragen van patiënten geconfronteerd. Daaraan voorbij gaan omdat dit niet tot hun taak hoort of dat ze zich daardoor te veel bemoeien met het leven van patiënten zou moreel niet te verantwoorden zijn.

I5 Zie bijvoorbeeld Baier (1989).

16 Zie bijvoorbeeld Gremmen (1995a).

I7 Zie bijvoorbeeld Gastmans \& Casterlé (2000) of Sevenhuijsen (1996).

18 Zie bijvoorbeeld Verkerk (1996).

I9 Zie bijvoorbeeld Van Bellingen (2000).

20 De manier waarop verpleegkundigen van afdeling to meningsverschillen met patiënten hanteren vertoont veel overeenkomsten met het proces van probleem oplossen dat Gremmen (2000) beschrijft voor wijkverpleegkundigen.

2 I Zie fasen van Tronto (1993).

22 Garanties geven, dat bemoeienis nooit te ver zal gaan, is volgens zorgethici onmogelijk. Ze gaan ervan uit dat de principe-ethiek dat ook niet kan. Zelfs als zelfbeschikkingsrecht van patiënten wordt gesteund door zorgverleners, betekent dit niet dat dit recht ook te allen tijden wordt beschermd. Net zo min als de principe-ethiek kan de zorgethiek voorkomen dat wensen van patiënten worden geschaad op een manier die onmogelijk te verdedigen is vanuit een opvatting dat dit het leven draaglijker maakt In een zorgethiek spelen deels dezelfde kwesties als in de principe-ethiek. Ook in deze ethiek word.t dwang of uitbuiting als probleem gedefinieerd. Er wordt echter niet verondersteld dat dergelijke problemen met een verwijzing naar een recht op zelfbeschikking kunnen worden opgelost. Voor een uitwerking van dit argument zie Little (i998). Bovendien gaat men er in een zorgethisch perspectief van uit dat de nadruk op een dergelijk recht ook nieuwe problemen kan creëren. Bijvoorbeeld mensen het gevoel geven dat ze in de steek gelaten worden of mensen verwaarlozen. Te veel nadruk op zelfbeschikkingsrecht kan volgens Tronto (Tronto, 1993) leiden tot "geprivilegieerde onverantwoordelijkheid".

23 Stelt met name Sevenhuijsen (1996).

24 De machtsverhoudingen tussen artsen en verpleegkundigen is vanaf het ontstaan van de beroepsgroep onderwerp van gedachtevorming. In eerste instantie werd deze relatie vooral beschreven in hiërarchische termen. De arts beslist en de verpleegkundige gehoorzaamt. Door een aantal ontwikkelingen zoals de verder professionalisering van de beroepsgroep werd dit beeld gewijzigd. Verpleegkundigen 
hebben daarbij steeds meer ruimte gekregen voor hun eigen inbreng door bijvoorbeeld een eigen gebied te claimen de patiënt centraal te stellen. Voor een dergelijke stelling zie Mesman (2002).

25 Voor een dergelijke conclusie zie het citaat van De Vente in Meinen (1993: 24).

26 Lipp (1998) stelt dat wanneer er meningsverschillen zijn tussen artsen en verpleegkundigen over de vraag of en hoe patiënten over hun situatie geînformeerd moeten worden, verpleegkundigen veelal het onderspit delven omdat ze minder macht hebben. De enige optie de ze volgens Lipp hebben is om patiënten de diagnose te vertellen. Deze strategie brengt risico's met zich mee, omdat dit de taak van artsen is.

27 Thé (1999) laat op basis van haar onderzoek zien dat verpleegkundigen ongelukkig zijn met de versluierende voorlichting die de artsen geven. Ze zien zich telkens geconfronteerd met ongeneeslijk zieke maar hoopvolle patiënten die zij niet uit de droom mogen helpen. Hoewel zij meer dan de artsen de zieken bijstaan in hun verwerkingsproces, is het inlichten van de patiënt over zijn ziekte nu eenmaal voorbehouden aan de arts.

28 Concludeert ook Mesman (2002).

29 Voor een bespreking van de invloed van de context van de afdeling of instelling op de zorg die verpleegkundigen geven zie bijvoorbeeld Cannaerts (2000) of Gastmans (2000).

Zie voor een dergelijk conclusie bij̣oorbeeld Mesman (2002).

\section{Hoofdstuk 8}

I. De opzet van dit onderzoek past daarmee onder de noemer van een 'abjectieve redeneerwijze'. Met deze term verwijzen Maso \& Smaling (1998: 30) naar een bepaalde verhouding tussen een theoretisch kader en dataverzameling. In tegenstelling tot een inductieve redeneerwijze (waarbij getracht wordt puur op basis van data een theorie te ontwikkelen) of een deductieve redeneerwijze (waarbij op basis van bevindingen een theorie wordt getoetst) stellen zij de abjectieve redeneerwijze voor. Hierbij wordt een globaal theoretisch kader gebruikt om gegevens te verzamelen, waarbij de theoretische uitgangspunten zelf ook weer aangescherpt; verdiept of verworpen kunnen worden op basis van de verzamelde gegevens. De stelling dat practici en ethici iets van elkaar kunnen leren sluit ook aan bij bepaalde stromingen binnen empirische ethiek (zie bijvoorbeeld Widdershoven (1999a). Uitgangspunt hierbij is dat inzicht in ervaringen van betrokkenen relevant is voor. ethische theorievorming. Ethiek verruilt het outsidersperspectief voor een insidersperspectief.

2 Binnen opleidingen en bijscholingen zou bijvoorbeeld aandacht besteed kunnen worden aan morele ervaringen van verpleegkundigen op de werkvloer. Voor een dergelijk standpunt zie Van de Arend \& Smits ( 2003). Tegen welke kwesties lopen verpleegkundigen binnen specifieke zorgpraktijken aan en hoe gaan ze daarmee om? Op basis van dit onderzoek kan geconcludeerd worden dat het daarbij zinvol is deze kwesties te bespreken in relatie tot concrete ervaringen van betrokken. Het type kwesties dat verpleegkundigen tegenkomen in de zorg die te maken hebben met het draaglijker maken van een kwetsbaarheid en eindigheid moeten vooral in het zorgend handelen zelf worden geleerd. Het organiseren en aangaan van een 
relatie, betrokken raken, meedenken en meeleven, een compagnon zijn, gezellig. heid brengen, sfeer creëren, patiënten stimuleren hun verhaal te vertellen, contact met familie ondersteunen, en dergeliịke viagen van verpleegkundigen om activiteiten en vaardigheden die vooral tijdens het zorgen zelf geleerd moeten worden. Morele ervaringen en activiteiten, zichtbaar gemaakt door middel van zorgethisch kwalitatief onderzoek, kunnen als aangrijpingspunt gebruikt worden in concrete praktijken op eigen ervaringen te reflecteren.

3 Zie bijwoorbeeld Dartel (1999a, b) en Hillmann \& Most (2001a, b).

4 Stellen een aantal auteurs (Benner et al. 1992, 1996; Boxtel et al. 20or; Davies 1995, 1998; Dickson 1993; Graham 1983; Gremmen 1995a; James I992; Smits 2000; Vulto \& Moree 1996).

5 Zie Vulto \& Moree (1996).

6 Voor een dergelijke stelling zie bijvoorbeeld Boeije etal. (1997) en Pool \& Grypdonk (1997). Zij pleiten ervoor in de zorg ruimte te creëren voor gestandaardiseerde zorg en tegelijkertijd specifieke zorgbehoeften van patiënten als uitgangspunt te nemen. Volgens Grypdonck (2000) moeten verpleegkundigen verantwoordelijkheid nemen en bereid zijn zelfstandig beslissingen te nemen die ertoe bijdragen dat het welzịin van patiënten wordt bevorderd. Dat inzicht is reeds uitgewerkt in 'Geïntegreerde Verpleegkunde'(ig92). Uitgangspunt hiervan is een model van patiëntentoewijzing, waarbij verpleegkundigen vanuit een houding van betrokkenheid en verantwoordelijkheid patiënten kunnen leren kennen, om zorg te geven die is toegesneden op specifieke vragen en behoeften.

7 Stellen een aantal auteurs (Dartel 1999a, b; Hillmann \& Most 2001a, b). 


\section{LITERATUUR}

Allison, A., \& Ewens, A.

1998 'Tension in sharing client confidence while respecting autonomy: Implications for interprofessional practice.' Nursing Ethics, 5, 5, 441*449.

Alimark, P.

1995 'Can there be an ethics of care?' Journal of medical ethics, 21, 19-24.

r995b 'Uncertainties in the teaching of ethics to students of nursing.' Journal of Advanced Nursing, 22, 374-378.

I998 'Is caring a virtue?' Journal of Advanced Nursing, 28, 3, 466-472.

Arend, A. J. G. van de

I988 'Verpleegkundigen.' In: H. M. Dupuis (red), Handboek gezondheidsethiek (pp. 275-285). Assen/Maastricht: Van Gorcum.

Arend, A. J. van de \& Smits, M. J.

2003 'Ethics Education: Does it make for ethical practice?' In: W. Tadd (eds) (pp. $97^{-100)}$. Ethics in nursing education, research and management. Palgrave Macmillan.

Arend, A. van de \& Gastmans, C.

1993 'Ethisch zorg verlenen, handboek voor de verpleegkundige beroepen.' Nijkerk: Intro.

Astrom, G., Jansson, L., Norberg, A., \& Hallberg, I. R.

1993 'Experienced nurses' narratives of their being in ethically difficult care situations.' Cancer Nursing, 16, 3, 179-187.

Baier, A. C.

1989 'Trust and Antitrust.' Ethics, 96, 231-260.

I993 'What women want in a moral theory.' In: M. J. Larrabee (eds), An ethic of care, feminist and interdisciplinary perspectives (pp. 19-33). New York:

Routledge.

1994 'Moral prejudices: essays on ethics.' Cambridge: Harvard University Press.

Bandman, E. L, \& Bandman, B.

I985 'Nursing ethics in the life span.' Norwalk, Connecticut:

Appleton-Century-Crofts.

Barnes, D. M., Davis, A. J., Moran, T., Portillo, C., \& Koenig, B. A.

1998 'Informed consent in a multicultural cancer patient population:

Implications for nursing practice.' Nursing Ethics, 5. 5, 312-42.3.

Bauman, Z.

I993 'Postmodern ethics.' Oxford: Blackwell Publishers.

Beauchamp, T. L., \& Childress, J.

I979 'Principles of biomedical ethics.' Oxford: University Press. 
Bellingen, R. van

2000 'Denken baart (het) zorgen'، In: C. Gastmans \& B. Dierckx de Casterlé (red), Verpleegkundige excellentie: Verpleegkunde tussen theorie en praktijk (Pp.

47-62). Maarssen: Elsevier gezondheidszorg.

Benner, B., Tanner, C. A., \& Chesla, C. A.

1996 'Expertise in nursing practice: caring, clinical judgment, and ethics.. New York: Springer Publishing Company.

Benner, $P$.

1984 'From novice to expert: Excellence and power in clinical nursing practice.' Menlo Park/CA: Addison-Wesley.

Benner, $\mathrm{P}$.

I99I 'The role of experience, narrative, and community in skilled ethical comportment.' Advances in Nursing Science, I4, 2, I-2I.

Benner, P., \& Tanner, C.

I987 'Clinical judgment: How experts nurses use intuition. The seasoned nurse's well-honed sixth sense enables her to make lifesaving decisions.' American Journal of Nursing, January, 2;3-31.

Benner, P., Tanner, C., \& Chesla, C.

1992 'From beginner to expert: Gaining a differentiated clinical world in critical care nursing.' Advances in Nursing, Science, 14, 3, 13-28.

Benner, P., \& Wrubel, J.

1998 'Nursing practice and the lived experience of illness.' In: M. Allott \& M. Robb (eds). Understanding health and Social Care (pp. 56-59). London: SAGE.

Bevis, E. O.

I98r 'Caring: A life force.' In M. Leininger (eds), Caring: An essential human need. New Yord: Charles Slack.

Bishop, A., \& Scudder, J. R.

1990 'The Practical, Moral, and Personnel Sense of Nursing. A Phenomenological Philosophy' of Practice.' Albany: State University of New York Press.

Bishop, A. H., \& Scudder, J. R.

1999 'A Philosophical Interpretation of Nursing.' Scholarly for Nursing Practice, 13, I, 17-27.

Blanc, P. M., Schaufeli, W. B., \& Heesch, N. C. A. v.

1998 'Burn-out bij oncologie verpleegkundigen, resultaten van een landelijk onderzoek.' Oncologica, 9-13.

Boeije. H. R. Dungen, A. W. L v. d., Pool, A., Grypdonk, M. H. F., \& Lieshout, P. A. H. van 1997 'Een verzorgde toelkomst: Toekomstscenario's voor verpleging en verzorging.' Scenariorapport in opdracht van de Stichting Toekomstscenario's Gezondheidszorg en mede gefinancierd door het Landelijk Centrum Verpleging en Verzorging. Utrecht: Nederlands Instituut voor Zorg en Welzijn \& vakgroep Verplegingswetenschap, Utrecht: Universitaire pers.

Boxtel, R. J. J. v., Smits, M. J., Engel, M., \& Boshuizen, H. P. A.

2001 'Intuitie in relatie tot het verpleegkundig proces.' TVZ, 8, 234-240.

Brody, J. K.

1988 'Virtue ethics, caring and nurșing.' Scholarly Inquiry for Nursing Practice, 2, 2, 87-97. 


\section{Brunklaus, O.}

2000 'Zorgen voor mensen mẹt kanker.' TVZ, 20, 6r4-6r7.

Cain, P.

1998 'The limits of confidentiality.' Nurșing Ethics, 5, 2, I59-164.

Calhoun, C.

1988 'Justice, care, gender bias.' The Journal of Philosophy, 85, 9, 451-463.

Calsbeek, H., Hingstman, L., Windt, W. v. d., \& Talma, H.

2000 'Feiten over verpleegkundig en verzorgende beroepsgroepen 2000.' TVZ, $23-24.728-732$.

Calsbeek, H., Windt, W. v. d., \& Hingstman, L.

I998 'Nieuwe feiten over verpleging en verzorging.' TVZ, 20, 609-6I4.

Campell, $\mathrm{T}$.

1999 'Feelings of oncology patients about being nursed in protective isolation as a consequence of cancer chemotherapy treatment.' Journal of Advanced Nursing, 30, 2, 439-447.

Cannaerts, $\mathrm{N}$.

2000 'Antwoord op maat: Verpleegkundig perspectief.' In: C. Gastmans \& B. Dierckx de Casterlé (red), Verpleegkundige excellentie: Verpleegkunde tussen theorie en praktijk (pp. 143-157). Maarssen: Elsevier gezondheidszorg.

Carper, B.

1978 'Fundamental patterns of knowing in nursing.' Advances in Nursing Science, I, I, 13-23.

Carse, A. L.

1998 'Impartial principle and moral context: Securing a place for the particular in ethical theory.' The Journal of Medicine and Philosophy, 23, 2, 153-169.

Code, L.

I990 'Who cares?' In: S. Sevenhuijsen (eds) Feminism, citizenship and care. Utrecht: Anna Maria van Schuurman Centrum.

I995 'Who cares? The poverty of objectivism for a moral epistemology.' In: L. Code (eds), Rhetorical spaces. Essays on gendered locations. New York/London: Routledge.

Cohen, M. Z., Haberman, M. R., \& Steeves, R.

r994 'The meaning of oncology nursing: a phenomenological investigation.'

Oncology nursing forum: Official publication of the oncology nursing society, 2r, $6,5.8$.

Cooper, M. C.

I99I 'Principle-oriented ethics and the ethic of care: A creative tension.' Advances in Nursing Science, I4, 2, 22-3I.

Courtens, A., Hagemeijer, J. W., Prins, K. J., Blok, S., \& Becque, Y. N.

1998 'Vermoeidheid en chemotherapie.' Verpleegkunde, 13, 3, 17I-183.

Crigger, N. . .

I997 The trouble with caring: A review of eight arguments against an ethic of care.' Joumal of Professional Nursing, 13, 4, 217.221.

Crowden, A.

1994 'On the moral nature of nursing practice.' Journal of Advanced Nursing, 20, IIO4-IIIO. 
Crowley, M. A.

1989 'Feminist pedagogy: Nurturing the ethical ideal.' Advances in Nursing Science, II, 3, 53-61.

Curtin, L., \& Flaherty, M. J.

1982 'Nursing Ethics: Theories and Pragmatics.' Maryland: Prentice-Hall publication.

Curzer, H. J.

I993a 'Fry's Concept of Care in Nursing Ethics.' Hypathia, 8, 3, 174-183.

$1993 \mathrm{~b}$ 'Is care a virtue for health care professionals?' The Journal of Medicine and Philosophy, I8, 5I-68.

Dartel, H. van

I999a 'Als mensen aandacht tekort komen, smaakt het kopje thee ook niet: Inleiding en kritiek', Expertseminar: Als mensen aandacht tekort komen, smaakt het kopje thee ook niet. Utrecht: Universiteit Utrecht.

Dartel, J. M. van

1999 b 'Employability en Empowerment.' Utrecht: NZf, CELAZ.

Davies, C.

1995 'Gender and the professional predicament in nursing.' Buckingham,

Philadelphia: Open University Press.

1998 'Caregiving, carework and professional care.' In: A. Brechin, J. Walmsley, J. Katz \& S. Peace (eds), Care Matters: Concepts, Practice and Research in Health and Social Care (pp. 126-138). London: SAGE Publications Ltd.

Davis, A. J.

I995 'Response to "aspects of Moral Knowledge in Nursing". : Scholarly inquiry for Nursing Practice, 9, 4, 355-358.

Davis, A. J., \& Aroskar, M. A.

1978 'Ethical Dilemmas and Nursing Practice.' New York: Appleton-Century-Crofts.

Delvecchio Good, M.-J., Good, B. J., Schaffer, C., \& Lind, S. E.

I990 'American oncology and the discourse of hope.' Culture, Medicine and Psychiatry, 14, 59-79.

Dickson, G. L.

1993 'The unintended consequences of a male professional ideology for the development of nursing education.' Advances in Nursing Science, 15, 3 , $67-83$.

Dierckx de Casterlé, B., Vijuer, L van de \& Tanghe, A.

2000 'Ethisch overleg ter ondersteuning van een verantwoorde zorg'. In: C. Gastmans \& B. Dierckx de Casterlé (eds.), Verpleegkundige excellentie: Verpleegkunde tussen theorie en praktijk (pp. 99-II9). Maarssen: Elsevier gezondheidszorg.

Dupuis, H. M., \& Beaufort, I. D. de

1988 'Informed consent.' In: I. D. de Beaufort \& H. M. Dupuis (red), Handboek Gezondheidsethiek. Assen/Maastricht.

Ebskamp, J., \& Kroon, H.

1993 'Ethisch leren denken: In de hulpverlening, verzorging en sociale dienstverlening.' Nijkerk: Uitgeverij Intro. 
Ersek, M., Scanlon, C., Glass, E., Ferrel, B. R., \& Steeves, R.

I995 'Priority ethical issues in oncology nursing: Current approaches and future directions.' Oncology nursing forum: official publication of the oncology nursing. society, 22, 5, 803-807.

Essen, L., Carlsson, M., \& Sjoden, P.-O.

I995 'Nursing behaviors that make patients feel cared for: Views of cancer patients, oncology nursing, and 'others'.' Journal of Psychosocial Oncology, 13, 3, 67-87.

Fisher, B., \& Tronto, J. C.

I991 'Toward a ferninist theory of care'. In: E. Abel \& M. Nelson (eds), Circles of Care: Work and Identity in Women's Lives. Albany: State University of New York Press.

Fitzpatrick, F. J.

I988 'Ethics in nursing practice: Basic principles and their application.' London: The Linacre Centre.

Flanagan, O., \& Jackson, $\mathrm{K}$.

1993 'Justice, care, and gender: The Kohlberg-Gilligan debate revisited.' In: M. J. Larrabee (eds), An ethic of care: Ferninist and interdisciplinary perspectives (pp. $69-87)$. New York: Routledge.

Fliedner, $\mathrm{M}$.

I997 'Kwaliteit van leven: 1525 reacties van kankerpatiënten.' Oncologica, I4, I, 59-6I. Fliedner, M. C.

I994 'Seksualiteit en intimiteit na beenmergtransplantatie - een verpleegkundige zorg?' Oncologica, II, 2, 15-19.

Fowler

I989 'Ethical decision making in clinical practice.' Nursing Clinics of North America, 24, 4, 955-964.

Fowler, M. D.

I986 'Ethics without virtue.' Heart and Lung, I5, 5. 528-529.

Fry, S. T.

1989 'The role of caring in a theory of nursing ethics.' HYpathia, 4, 2, 88-103. Gadow, S.

I983 'Existential Advocacy: Philosophical foundation of nursing.' In: C. P. Murphy \& H. Hunter (eds), Ethical problems in the nurse-patient relationship. Newton, Massachusetts: Allyn and Bacon, Inc.

I988 'Covenant without cure: Letting go and holding on in chronic illness.' In: J. Watson \& M. Ray (eds), The ethics of care and the ethics of cure: synthesis in chronicity. New York: National League for Nursing.

Gastmans, C.

I995a 'Verpleegkunde, zorg en ethiek.' Verpleegkundigen en gemeenschapszorg, 51, 2, 70-71.

1995b 'Verpleegkunde, zorg en ethiek. Historische, wijsgerig-antropologische en moraaltheologische grondlijnen van een verpleegkundige ethiek, opgevat als een zorgzaamheidsethiek.' Leuven: Katholieke Universiteit.

I995C 'Verpleegkundige praktijkvoering' en theorie-ontwikkeling: Nieuwe perspectieven vanuit de ethiek.' Verpleegkunde, 3/4, 137-139. 
1996 'Zorgzaamheid. Een essentiële waarde in de verpleegkunde.' Verpleegkundigen en gemeenschapszorg, 52, 4, $155-156$.

1998 'Challenges to nursing values in a changing nursing environment.' Nursing Ethics, 5, 3, 236-245.

2000 'Morele houdingen in de verpleegkunde.' In: C. Gastmans \& B. Dierckx de' Casterlé (eds), Verpleegkundige excellentie: Verpleegkunde tussen theorie en praktijk (pp. 63-75). Maarssen: Elsevier gezondheidszorg.

Gastmans, C., \& Dierckx de Casterlé, B.

2000 'Verpleegkundige excellentie: Verpleegkunde tussen praktijk en ethiek.' Maarssen: Elsevier gezondheidszorg.

Gastmans, C., Dierckx de Casterlé, B., \& Schotsmans, P.

1998 'Nursing considered as moral practice: A philosophical-ethical interpretation of nursing.' Kennedy Institute of Ethics Journal, 8, I, 43-69.

Gastmans, C., Dierckx de Casterlé, B., Bellingen, R. van, Aubry, C., Leyn, A. M. D., Deneire, M., Verschueren, M., \& Vranckx, P.

2000 'Ethische aspecten van de verpleegkundige praktijk: Een basisvisie.' In C. Gastmans \& B. Dierckx de Casterlé (eds), Verpieegkundige excellentie: Verpleegkunde tussen theorie en praktijk (pp. 35-45). Maarssen: Elsevier gezondheidszorg.

Gilligan, C.

I982. 'In a different voice.' Cambridge: Harvard University Press.

1985 'Een ander geluid.' Amsterdam: Uitgeverii Bert Bakker.

Graham, H.

I983 'Caring: a labour of love.' In: J. Finch \& D. Groves (eds), Labour of Love: Women, Work and Caring. London: Routledge and Kegan paul.

\section{Gremmen, I.}

I992 'Responsibility as situated ethic: Understanding care in a concrete context.' In: K. Davis (eds), Feminist discourse and the rhetoric of responsibility. Utrecht: Anna Maria van Schuurman Centrum.

I995a 'Ethiek en professionaliteit in de gezinsverzorging.' Tijdschrift voor de Sociale Sector, juni, 6.

1995b 'Ethiek in de gezinsverzorging: Gender en de macht van zorg.' Utrecht: Uitgeverij Jan van Arkel.

1997 'Verzorgend werk en zorgethiek. Het belang van een feministische invalshoek.' In: M. Verkerk (red), Denken over zorg. Utrecht: Elsevier/De Tijdstroom.

2000 'Goede zorg in de wijk: Verpleegkundigen over de ethiek van hun dagelijkse werk.' TVZ, 3, 86-9o.

Grypdonck, $\mathrm{M}$.

1992 'Integrerende verpleegkunde: Een situatie scheppende theorie.' In: H.

Bruggen van de (red). De delta van de Nederlandse Verpleging (pp. I30-I49). Lochem: De Tijdstroom.

2000 'Professionalisering en ethiek: Beroepsperspectief:' In: C. Gastmans \& B. Dierckx de Casterlé (red), Verpleegkundige excellentie: Verpleegkunde tussen theorie en prakiijk (pp. 203-22I). Maarssen: Elsevier gezondheidszorg.

Hammersley, M., \& Atkinson, P.

${ }_{1983}$ 'Ethnography, principles in practice.' London: Routledge. 
Have, A. M. J. ten

1998 'Medical ethics research.' Theoretical Medicine and Bioethics, 19, 277-293.

Heijst, A. van

1995 Verlangen naar de val. Kampen: Kok Agora.

Heitman, L. K., \& Roberson, B. E.

1997 'Developing a Nursing Ethics Roundtable.' AJN, 97, I, 36-38.

Hillmann, H., \& Most, H. van der

200ra 'Boeien en binden: De specifieke kunst van het managen van

verpleegkundigen.' TVZ, I, ro-rI.

$200 \mathrm{Ib}$ 'Boeien en binden - 2, De kunst van het managen van verpleegkundigen.' TVZ, 2, 42-47.

Hoorebeke, F. van

2000 'Zullen er nog verpleegkundigen nodig zijn?' TVZ, 3. 75-77.

Houten, D. van, \& Lieshout, P. van

1994 'De institutionalisering van zorg.' In: H. Manschot \& M. Verkerk (red), Ethiek van de zorg: Een discussie (pp. II-37). Amsterdam Meppel: Boom. Houtepen, R., Smits, M.j.

1993/1994 'Van regelethiek naar zorgethiek.' Wijsgerig perspectief op maatschappij en wetenschap, 34, 5, 162-167.

Hoven, M. J. van de \& Tenwolde, J.

I988 'Toegepaste ethiek en verplegen.' TVZ, 42, 4, I05-108.

Husted, G. L., \& Husted, J. H.

I99I 'Ethical decision making in nursing.' St. Louis: Mosby-Year Book, Inc. James, $\mathrm{N}$.

I992 'Care = organization + physical labour + emotional labour.' Socoilogy of Health \& Illness, 14, 4, 488-509.

Kamphuis, T., \& Morrison, M.

I988 'Verpleegkundigen \& Ethiek.' Groningen: Wolters Noordhoff.

Kanne, M.

1994 'Professional nurses should have their own ethics: The current status of nursing ethics in the Dutch curriculum.' Nursing ethics, I, I, 25-33.

Keller, J.

1997 'Autonomy, relationality, and feminist ethics.' Hypathia, 12, 2, 152-164. Koopman, P.

2001. 'Verpleegkundigen schaars?' TVZ, I, I2-17.

Kruijswijk Jansen, J.

2000 'Verplegen: professioneel huis- tuin en keukenwerk?' TVZ, 2, 45-49. Kuhse, $\mathrm{H}$.

1995 "Against the stream: Why nurses should say "no" to a female ethics of care."

Revue internationals de Philosophy, 49, 193, 285-304.

Kuüppelomaki, M., \& L., S.

1998 'Ethical dilemmas in the care of patients with incurable cancer.' Nursing Ethics, 5. 4, 283.291. 
Lagae, R., \& Verschueren, M.

2000 'Zorg als prioriteit: Beleidsperspectief.' In: C. Gastmans \& B. Diercksx de Casterlé (red), Verpleegkundige excellentie: Verpleegkunde tussen praktijk en ethiek (pp. 159-169). Maarssen: Elsevier gezondheidszorg.

Lange, J. de Pronk, M., \& Smaling, A.

1999 'Participerende observatie in verpleegkundig onderzoek.' Verpleegkunde, I4, $4,226-236$.

Leininger, $M$.

I981. 'CARING an essential human need: Proceedings of the three national caring conferences.' New Jersey: Charles B. Slack Inc.

Lelie, A.

1999 'Ethiek en nefrologie: Een empirisch-ethisch onderzoek.' Leende: Damon.

Lievaart, P.

1999 'Een ethisch dilemma.' Oncologica, I6, 4, 35-37.

Lipp, A.

1998 'An enquiry into a combined approach for nursing ethics.' Nursing Ethics, 5 , 2, 122-138.

Little, M. O.

1998 'Care: From Theory to Orientation and Back.' The Journal of Medicine and Philosophy, 23, 2, 190-209.

Lutzen, $\mathrm{K}$.

1997 'Nursing ethics into the next millennium: A context-sensitive approach for nursing ethics.' Nursing Ethics, 4, 3, 218-226.

Lycke, S. van der

2000 'Georganiseerde liefde: Publieke bemoeienis met zorg in de privésfeer.' Amsterdam: Aksant.

MacIntyre, $M$.

1981 'After virtue: A study in moral theory.' Notre Dame: University of Notre Dame Press.

Manenschijn, G.

${ }_{19184}$ 'Morele argumentatie.' In: A. W. Musschenga (red), Onderwijs in de natuurwetenschappen en morele vorming (pp. I60-180). Baarn: Ten Have.

Manneke, A.

I990 'Thema's voor verpleegkundigen.' Baarn: Nelissen.

Manschot, $\mathrm{H}$.

1997 'Zorg: Een blinde vlek in de moderne filosofie.' In: M. Verkerk (red),

Denken over zorg. Concepten en praktijken. Utrecht: Elsevier/De Tijdstroom.

Manschot, H., \& Verkerk, M.

1994 'Ethiek van de zorg: Een discussie.' Amsterdam Meppel: Boom.

Maso, 1., \& Smaling, A.

1998 'Kwalitatief onderzoek: Praktijkonderzoek.' Amsterdam Meppel: Boom.

Meinen, A.

1993 'Verpleegkundigen moeten hun keuzen in de zorg veroveren.' Tijdschrift poor Gezondheid en Politiek, II, 2, 24-25.

Melia, K. M.

1994 'The task of nursing ethics.' Joumal of medical ethics, 20, 7-11. 
Mendus, $\mathrm{S}$.

I993 'Different voices still lives: Problems in the ethics of care.' Journal of Applied Philosophy, I0, I, I7-27.

Mesman, J.

1989 'Proces in beweging: Betekenisveranderingen van het begrip "verpleegkundig proces".' Scriptie: Gezondheidswetenschappen Universiteit Maastricht.

2002 'Evvaren pioniers: Omgaan met twiffel in de intensieve care voor pasgeborenen.' Amsterdam: Aksant.

Meyers, D. T.

1987 'The socialized individual and individual autonomy: An intersection between philosophy and psychology.' In: K. E.F. \& D. T. Meyers (eds), Woman and Moral Theory. Totowa: Rowman and Littlefield.

1992 'Personal autonomy or the deconstructed subject? A reply to Hekman.' Hypatia, 7, I24-131.

1993 'Moral reflection: Beyond impartial reason.' Hypatia, 8, 3, $21-47$. Meykamp, W., Terpstra, S., \& Westerhuis, P.

1992 'Ethiek: Basisboek.' Groningen: Wolters-Noordhoff.

Noddings, $\mathrm{N}$.

I984 'Caring: A feminine approach to ethics a moral education.' London: Routledge. Nortvedt, P.

$199^{8}$ 'Sensitive judgment: an inquiry into the foundations of nursing ethics.' Nursing Ethics, 5, 5, 385-393.

Nussbaum, M. C.

I986 'The fragility of goodness: Luck and ethics in Greek tragedy and philosophy." Cambridge: Cambridge University Press.

Nuy, M., Steinkamp, N., Dekkers, W., \& Gordijn, B.

2000 'Moreel beraad in de eerste lijn: Over noodzaak en weldaad van bezinning op morele dilemma's.' TVZ, I2, 380-382.

Olsen, D. P.

I992 'Controversies in nursing ethics: A historical review.' Joumal of Advanced Nursing, I7, 1020-1027.

Omery, a.

I989 'Values, moral reasoning and ethics.' Nursing Clinics of North America, 24, 2, 499-508.

Parker, R. S.

I990 'Nurses' stories: The search for a relational ethic of care.' Advances in Nursing Science, $13, \mathrm{r}, 31-40$.

Pasch, T. v, d.

2000 'Emoties en chemotherapie: Begeleiding van kankerpatiënten kan beter.' TVZ, I3, 4I4-4I7.

Pellegrino, E. D., \& Thomasma, D. C.

I988 'For the Patient's Good.' New York: Oxford University Press.

Pool, A., \& Grypdonk, M.

1997 'Twee oriëntaties in de gezondheidszorg: Diagnosegestuurd of behoeftegestuurd.' TVZ, 10, 292-295. 
Pool, R.

I996 'Vragen om te sterven: Euthanasie in een Nederlands ziekenhuis.' Rotterdam: WYT Uitgeefgroep.

Radwin, L.

2000 'Oncology patients' perceptions of quality nursing care.' Research in Nursing Q Health, 23, 179-190.

Radwin, L, \& Alster, K.

I999 'Outcomes of perceived quality nursing care reported by oncology patients.' Scholarly Inquiry for Nursing Practice, 13. 4, 327-343.

Riekwel, C. P.

1996 'Verplegen op het randje van de dood.' TVZ, 13/14, 424.

Rijksen, H., \& Aarts, J.

1993 'Ethiek in de gezondheidszorg.' Best: DAMON.

Rijksen, H., Vestjens, M., \& Aarts, M.

1991 'Ethische vorming voor de gezondheidswerker.' Best: Damon.

Ruddick, S.

I980 'Maternal thinking.' Feminist Studies, 6, 343-367.

Salsberry, P. J.

1992 'Caring, virtue theory, and a foundation for nursing ethics.' Scholarly Inquiry for Nursing Practice, 6, 2, 155-167.

Sarvimaki, A.

1995 'Aspects of moral knowledge in nursing.' Scholarly Inquiry for Nursing Practice, 9, 4, 343-353.

Schermer, $M$.

2001 'The different faces of autonomy: A study on patient autonomy in ethical theory and hospital practice", Ridderkerk: Ridderprint.

Schumacher, J. N. M.

1997 'Verpleegkundige adviesraden in opkomst: De VAR als 'tool' voor modem management.' Verpleegkundig management, 4, augustus, II.-I3.

Scott, P. A.

1998 'Professional ethics: Are we on the wrong track?' Nursing Ethics, 5, 6.

Sellman, D.

1997 The virtues in the moral education of nurses: Florence Nightingale revisited. Nursing Ethics, $4,1,3-11$.

Sevenhuijsen, S.

1996 'Oordelen met zorg: Feministische beschouwingen over recht, moraal en politiek'. Amsterdam/Meppel: Boom.

1997 'New Directions in the Ethics of care. Feminist epistemologies of care.'

Smits, M. J.

1996 'Ethiek van de verpleegkundige praktijk: ZORGETHIEK \& regelethiek?' Verpleegkunde, 12, 1, 27-36.

2000 'Is professionele zorg ook goede zorg?' $T V Z, 10,313-318$.

Taylor, C.

1994 'De Malaise van de Moderniteit.' Kampen: Kok Agora.

Tenwolde, $\mathrm{H}$.

1993) 'Met alle respect: Leerboek verpleegethiek:' Nijkerk: Intro. 
Tenwolde, $\mathrm{H}$.

I995 'Beroepsethiek in de verpleging.' Tijdschrift voor Gezondheid en Politiek, Februari, I, 10-13.

1998 'Met alle respect: Leerboek verpleegethiek.' Baarn: Intro.

Termeulen, R.

1994 'Verschraalde zorg? Over autonomie, identiteit en zingeving in de zorg voor hulpbehoevende ouderen.' Rede uitgesproken bij de aanvaarding van het ambt van hoogleraar aan de universiteit Maastricht.

Thé, A.-M.

I997 'Vanavond om 8 uur ...', Verpleegkundige dilemma's bij euthanasie en andere beslissingen rondom het levenseinde.' Houten/Diegem: Bohn Stafleu Van Loghum.

1999 'Palliatieve behandeling en communicatie, Een onderzoek naar het optimisme op herstel van longkanke patiënten. ' Houtem Diegem: Bohn Stafleu Van Loghum.

Thiel, G., \& Hoven, M. van den

I999 'Als mensen aandacht tekort komen, smaakt het kopje thee ook niet.' Utrecht: Centrum voor Bio-ethiek en Gezondheidsrecht.

Thomasma, D.

1992 'The ethics of caring for the older patient with cancer: Defining the issues.' Oncology, 6, 2, 124-130.

Thompson, 1. E., Melia, K. M., \& Boyd, K. M.

1983; 'Nursing Ethics:' Edinburgh: Longman Group Limited.

Thompson, J. B., \&. Thompson, H. O.

1981 'Ethics in Nursing.' New York/London: Macmillan Publishing Co./Collier Macmillan Publishers.

Tongeren, P. van

1993 Deugdelijk leven. Een inleiding in de deugdethiek. SUN, Amsterdam 2003.

1997 'Gelukkig zijn=gelukt, zijn.' Filosofie magazine, 6, 7. 28-32.

Tronto. I.

I993. 'Moral boundaries: A political argument for an ethic of care.' New York: Routledge.

1997 'Verkeerde vooronderstellingen, verkeerde keuzen: Een feministische perspectief op zorg en gezondheid.' In: M. Veikerk (eds), Denken over zorg. Utrecht: Elsevier/De tijdstroom.

Veatch. R. M.

1981 'Nursing ethics, physician ethics, and medical ethics.' Law Med Health Care, 9. $17 \cdot \overline{1} 9$.

Veluw, $\mathrm{H}$.

1997 'Moedig patiënten aan hun verhaal te vertellen!' Oncologrica: tijdschrift

Verkerk, $M$. oncologie verpleegkunde, I4, I, 23-26.

1994 'Zorg of contract: Een andere ethiek.' In: H. Manschot \& M. Verkerk (red), Ethiek van de zorg. Een discussie. Meppel Amsterdam: Boom.

1996 'Mijnheer, heb ik met u een zorgrelatie? Over ethiek', over zorg en over een ethiek van de zorg. 'Rede uitgesproken ter aanvaarding van het ambt van hoogleraar, Rijksuniversiteit Groningen.

I997a 'Denken over zorg: Concepten en praktịken.' Utrecht: Elsevier/De Tijdstroom. 
1997b. 'Een ethiek van kwetsbaarheid: Over de verzwegen premisse.' In: M. Verkerk (red), Denken over zorg. Concepten en praktijken. Utrecht: Elsevier/De Tijdstroom.

1998. 'Zorgethiek: Over het stekelvarken, vrouwelijkheid en moraal.' Tijdschrift voor geneeskunde en ethiek, 8, 4, II5-I2I.

I999 'A care perspective on coercion and autonomy.' Bioethics, 13, 3/4, 358-368.

2001 'Over drang als goed zorgen: Een zorgethische beschouwing.' Tijdschrift voor gezondheid en ethiek, II, 4, IOI-106.

Vries, G. H. de

1993 'Gerede twijfel: Over de rol van medische ethiek in Nederland.' Amsterdam: De Balie.

Vulto, M., \& Moree, M.

1996 'Thuisverzorging als professie: Een combinatie van hand, hoofd en hart. Utrecht: De Tijdstroom.

Waerness, $\mathrm{K}$.

I990 'Gender and the rationality of caring.' In: S. Sevenhuijsen (eds), Feminism, citizenship and care. Utrecht: Anna Maria van Schuurman Centrum.

Walker, $M$.

$x 997$ 'Geographies of responsibility.' Hastings Center Report, 27, I, 38.49. Watson, J.

I985 'Nursing: Human Science and Human Care.' New York: Appleton Century Crofts.

1992. 'Response to "Caring, Virtue Theory, and a Foundation for Nursing Ethics".' Scholarly Inquiry for Nursing Practice, 6, 2, 169-17r.

Watts, D. T., McCaulley, B. L., \& Priefer, B. A.

1990 'Physician-nurse conflict: Lessons from a clinical experience.' Journal of the American Geriatrics Society, 38, IO, II5I-II52.

Widdershoven, G.

1995 'Principes of praktijk: Een hermeneutische visie op gezondheid en zorg', Rede uitgesproken ter aanvaarding van het ambt van hoogleraar, Universiteit Maastricht.

I999a 'Ethiek en empirisch onderzoek: Een pleidooi voor interpretatie en contextualiteit.' Ethiek en empirie, 2, 145-155.

2000 'Ethiek in de kliniek.' Amsterdam: Boom.

Widdershoven, G., \& Smits, M. J.

1996 'Ethics and Narratives.' In: Josselson (eds), Ethics and Process in the Nartative Study of Lives (pp. 275-287). Londen: Sage.

Widdershoven, G. A. M.

I999b 'Care, cure and interpersonal understanding.' Journal of Advanced Nursing. $29,5,1163 \cdot 1169$.

Willems-Cavalli, Y.

I997 'Ethische dilemma's in de oncologie verpleegkunde'. Oncologica, I4, I, 15-20. Wiliams, B. A. O.

I985 'Ethics and the limits of philosophy.' Cambridge: MA.

Willigenburg, T. van, Beld, A. van de, Heeger, F. R., \& Verwey, M. F.

1993 'Ethiek in praktijk.' Assen: Van Gorcum. 


\section{Bijlagen}

\section{BiJlage A: VERPLEGKUNDIGE ETHIEK IN SCHEMA}

\begin{tabular}{|c|c|c|c|}
\hline & Principe-ethiek & Deugdethiek & Zorgethiek \\
\hline $\begin{array}{l}\text { Waarvoor heeft ethiek } \\
\text { aandacht? }\end{array}$ & $\begin{array}{l}\text { Afzonderlijke } \\
\text { handelingsvraagstukken }\end{array}$ & $\begin{array}{l}\text { Goede zorg, gericht op het } \\
\text { bevorderen van een } \\
\text { menswaardig bestaan of } \\
\text { welzijn van zorgvragers }\end{array}$ & $\begin{array}{l}\text { Activiteit van het. zorgen " } \\
\text { gericht op het bevorderen } \\
\text { van een zo draaglijk } \\
\text { mogelijk bestaan }\end{array}$ \\
\hline Doel van ethiek & $\begin{array}{l}\text { Samenleven bevorderen en } \\
\text { tegelijkertijd vrijheid van } \\
\text { m.n. zorgvragers } \\
\text { garanderen }\end{array}$ & $\begin{array}{l}\text { Menswaardig bestaan of } \\
\text { welzijn van zorgvragers } \\
\text { bevorderen }\end{array}$ & $\begin{array}{l}\text { Zorgen voor een zo } \\
\text { draaglijk mogelijk bestaan, } \\
\text { dat woor ieder die daarbij } \\
\text { betrokken is werkbaar en } \\
\text { leefbaar is }\end{array}$ \\
\hline $\begin{array}{l}\text { Welke morele kwesties } \\
\text { staan centraal? }\end{array}$ & $\begin{array}{l}\text { Situaties waarin principes } \\
\text { (of daarvan afgeleide } \\
\text { waarden, normen, rechten } \\
\text { of plichten) botsen: } \\
\text { Niet schaden } \\
\text { Weldoen } \\
\text { Rechtvaardigheid } \\
\text { Autonomie }\end{array}$ & $\begin{array}{l}\text { Kwesties die samenhangen } \\
\text { met: } \\
\text { Bedreiging van welzijn van } \\
\text { zorgvragers of hun } \\
\text { menswaardig bestaain } \\
\text { zoals: pijn, lijden, relaties, } \\
\text { zelfontplooiing, } \\
\text { zelfverwerkelijking, } \\
\text { zelfrespect, etc. } \\
\text { Kwaliteit van relaties }\end{array}$ & $\begin{array}{l}\text { Kwesties die samenhangen } \\
\text { met: } \\
\text { Bedreiging van een zo: } \\
\text { draaglijk mogelijk bestaan } \\
\text { (zie deugdethiek) } \\
\text { Kwaliteit van relaties } \\
\text { Verdeling van } \\
\text { verantwoordelijkheden } \\
\text { Voorwaarden voor zorg } \\
\text { Kwesties waarin principes } \\
\text { botsen }\end{array}$ \\
\hline $\begin{array}{l}\text { Welke betekenis krijgt } \\
\text { autonomie? }\end{array}$ & $\begin{array}{l}\text { Zelfbeschikkingsrecht } \\
\text { (in vrijheid leven) }\end{array}$ & $\begin{array}{l}\text { Wordt niet specifiek } \\
\text { uitgewerkt in deugdethiek } \\
\text { binnen de verpleging }\end{array}$ & $\begin{array}{l}\text { Relationele authenticiteit } \\
\text { (een leven leiden dat } \\
\text { leefbaar is en bij jezelf } \\
\text { past) }\end{array}$ \\
\hline Rol van principes & Staan centraal & $\begin{array}{l}\text { Eén van de factoren die } \\
\text { een rol spelen } \\
\text { Zijn niet het uitgangspunt } \\
\text { Ook kwesties waarin. } \\
\text { principes geen rol spelen, } \\
\text { kunnen als moreel worden } \\
\text { benoemd } \\
\text { Het gaat niet om een } \\
\text { keuze tussen principes, } \\
\text { maar om het goede } \\
\text { midden }\end{array}$ & $\begin{array}{l}\text { Zie deugdethiek + } \\
\text { principes hebber geen } \\
\text { algemene geldigheid } \\
\text { Worden opgevat als } \\
\text { praktijkgebonden waarden } \\
\text { Kunnen in specifieke } \\
\text { contexten van betekenis } \\
\text { veranderen }\end{array}$ \\
\hline
\end{tabular}




\begin{tabular}{|c|c|c|c|}
\hline & Principe-thiek & Deugdethiek & Zorgethiek \\
\hline $\begin{array}{l}\text { Hoe worden morele } \\
\text { kwesties gehanteerd? }\end{array}$ & $\begin{array}{l}\text { Rechtvaardig oordelen } \\
\text { door systematisch, } \\
\text { objectief en onpartijdig } \\
\text { wegen van principes, } \\
\text { waardoor willekeur, } \\
\text { eigenbelangen en } \\
\text { specifieke voorkeuren zo } \\
\text { veel mogelijk worden } \\
\text { uitgesloten }\end{array}$ & $\begin{array}{l}\text { Ontwikkelen en inzetten } \\
\text { van relationele deugden }\end{array}$ & $\begin{array}{l}\text { Door te zorgen en d.w.z.: } \\
\text { Ontwikkelen en gebruik } \\
\text { maken van relationele } \\
\text { deugden } \\
\text { Verzamelen van } \\
\text { praktische kennis } \\
\text { Procesmatig zorgen } \\
\text { Communicatie, reflectie } \\
\text { en dialoog }\end{array}$ \\
\hline $\begin{array}{l}\text { Waarom is deze ethiek } \\
\text { ontstaan? }\end{array}$ & $\begin{array}{l}\text { Individuele vrijheid en } \\
\text { persoonlijke levenssfeer } \\
\text { beschermen, door: } \\
\text { Nadruk op } \\
\text { zelfbeschikkingsrecht } \\
\text { Paternalisme af te wijzen }\end{array}$ & $\begin{array}{l}\text { Menswaardig bestaan of } \\
\text { welzijn van patiënten } \\
\text { bevorderen, door: } \\
\text { Kwaliteit van } \\
\text { verpleegkundige patiēnt } \\
\text { relatie te verbeteren }\end{array}$ & $\begin{array}{l}\text { Draaglijker maken van het } \\
\text { bestaan, door: } \\
\text { Verbondenheid te } \\
\text { benadrukken (i.p.v. } \\
\text { individuele vrijheid) } \\
\text { Voorkomen dat mensen } \\
\text { aan hun lot worden } \\
\text { overgelaten }\end{array}$ \\
\hline $\begin{array}{l}\text { Is er aandacht voor } \\
\text { morele ervaringen van } \\
\text { betrokkenen binnen een } \\
\text { specifieke context? }\end{array}$ & $\begin{array}{l}\text { Ethische principes zijn } \\
\text { het uitgangspunt van } \\
\text { reflectie } \\
\text { Morele ervaringen worden } \\
\text { m.n. bestudeerd om te } \\
\text { achterhalen in hoeverre } \\
\text { ethische principes worden } \\
\text { gerespecteerd }\end{array}$ & $\begin{array}{l}\text { Nee, niet door auteurs die } \\
\text { in dit proefschrift onder } \\
\text { de noemer van } \\
\text { deugdethiek zijn } \\
\text { samengebracht }\end{array}$ & $\begin{array}{l}\text { Uitgangspunt van } \\
\text { ethische reflectie zijn } \\
\text { morele ervaringen van } \\
\text { betrokkenen } \\
\text { Denken en handelen van } \\
\text { betrokkenen binnen een } \\
\text { specifieke context is } \\
\text { uitgangspunt om zorg te } \\
\text { evalueren }\end{array}$ \\
\hline $\begin{array}{l}\text { Worden morele kwesties } \\
\text { in hun context geplaatst? }\end{array}$ & Als casuisstiek & $\begin{array}{l}\text { Morele kwesties spelen } \\
\text { zich af binnen de relatie } \\
\text { tussen verpleegkundige } \\
\text { en patiënt en de context } \\
\text { van de zorgverlening }\end{array}$ & $\begin{array}{l}\text { Ja, want deze heeft } \\
\text { invloed op het ontstaan } \\
\text { van morele problematiek } \\
\text { en bepaalt mede de } \\
\text { ruimte om goede zorg te } \\
\text { verlenen }\end{array}$ \\
\hline $\begin{array}{l}\text { Specifieke problemen die } \\
\text { besproken worden in } \\
\text { verband met deze ethiek }\end{array}$ & $\begin{array}{l}\text { Werkt afstandelijkheid in } \\
\text { hand } \\
\text { Weinig ruimte voor } \\
\text { morele kwesties die } \\
\text { buiten de categorie van } \\
\text { principes vallen }\end{array}$ & $\begin{array}{l}\text { Een verplegende die over } \\
\text { de juiste deugden } \\
\text { beschikt hoeft nog geen } \\
\text { goede zorg te verlenen } \\
\text { Alleen aandacht voor hoe } \\
\text { te zijn, maar niet voor de } \\
\text { kwaliteit van het handelen }\end{array}$ & $\begin{array}{l}\text { Geeft alleen } \\
\text { communicatie reflectie en } \\
\text { dialoog als houvast om } \\
\text { grenzen aan te geven }\end{array}$ \\
\hline
\end{tabular}




\section{BijLAGE B:}

\section{INTERVIEWSCHEMA VOOR SEMI-GESTRUCTUREERDE DIEPTE INTERVIEWS}

\section{Introductie}

Gegevens worden vertrouwelijk en anoniem verwerkt.

Toestemming vragen voor gebruik van cassetterecorder.

Kort uitleggen waar het interview over gaat, namelijk: wat onder goede zorg wordt verstaan. Wat is voor jouw belangrijk in de zorg? Welke zorg wil je aan patiënten geven?

Uitleg geven over gesprek, namelijk de lijst met vragen vormt een richtlijn voor het gesprek voor de interviewer. De vragen dienen vooral als handleiding. Het zijn punten die aan de orde kunnen komen, echter niet noodzakelijk in deze volgorde. Als tijdens het interview nieuwe, relevante punten aan de orde komen, zal daarover verder door gepraat worden.

De bedoeling van het gesprek uitleggen, namelijk zicht krijgen op jouw ervaringen. Je antwoorden kunnen daarom nooit goed of fout zijn. Ik wil jouw mening horen. Bovendien wil ik graag horen hoe het er op de werkvloer aan toegaat. Daarom zal er veel gevraagd worden naar concrete voorbeelden uit de praktijk. Ook kunnen voorbeelden uit de praktijk worden ingebracht die door de onderzoeker zijn geobserveerd.

(Algemene manier van doorvragen:

Wat bedoel je daarmee?

Kun je dat uitleggen?

Dus je bedoelt ...?

Begrijp ik het goed dat ...?

Kun je daar een voorbeeld van geven?

Wat is het verschil met ....?)

\section{Vragenlijst}

\section{Motivatie om te verplegen}

Zou je me kunnen vertellen wat jou gemotiveerd heeft om verpleegkundige te worden?

Aandachtspunten om door te vragen:

Ben je iemand die graag zorgt?

Voel je je betrokken bij het leed van anderen?

Zie je verplegen als een baan als alle andere?

\section{Motivatie om op oncologie te gaan werken}

Was er nog een specifieke reden om voor oncologie te kiezen?

Wat trekt je aan in oncologieverpleging?

Zou je ook op een andere afdeling willen werken? Waarom wel? Waarom niet? 
Aandachtspunten om door te vragen:

Heeft het type ziekte te maken met de keuze?

Heeft begeleiding van patiënten te maken met de keuze?

Heeft de complexiteit te maken met de keuze?

Heeft medisch technisch kennis en vaardigheden te maken met de keuze?

\section{Zorguisie}

Zou je me een voorbeeld kunnen geven van zorg voor een patiënt van de oncologieafdeling, waarbij je achteraf heel tevreden was over de manier waarop die zorg door jou en je collega's gegeven is? Kun je me een situatie vertellen waar je echt een goed gevoel over had.

Zou je me kunnen vertellen welke eisen je aan jezelf stelde in deze situatie?

Wat heb jezelf gedaan om ervoor te zorgen dat deze patiënt goede zorg kreeg?

\section{Aandachtspunten om door te vragen:}

Wat vond je belangrijk in de zorg voor deze patiënt?

Was het voor jou duidelijk wat de zorgbehoefte van deze patiënt was?

Hoe ging je met deze patiënt om? Hoe zag je relatie met deze patiënt eruit?

Wat betekende het voor deze patiënt om ziek te zijn?

Wat betekende het voor deze patiënt opgenomen te zijn op oncologieafdeling?

Hoe was je relatie met de familie?

voelde je je verantwoordelijk voor de zorg voor deze patiënt?

Had je voldoende kennis van het ziektebeeld om voor deze patiënt te zorgen? Is dat ook in andere zorgsituaties zo?

Had je voldoende vaardigheden om voor deze patiënt te zorgen? Is dat ook in andere zorgsituaties zo?

Speelde je ervaring bij de zorg voor deze patiënt een rol? Is dat ook in andere zorgsituaties zo?

Speelde je intuitie bij de zorg voor deze patiènt een rol? Is dat ook in andere zorgsituaties zo?

Hoe verliep de samenwerking met andere verpleegkundigen in deze situatie? Is dat ook in andere zorgsituaties zo?

Hoe verliep de samenwerking met andere zorgverleners in deze situatie? Is dat ook in andere zorgsituaties zo?

Heb je gebruik gemaakt van een protocol in deze situaties? Hoe heb je dit protocol toegepast?

Kon je deze patiënt uit je hoofd zetten als je 's avonds naar huis ging?

Zou je me kunnen vertellen waarom je deze eisen aan jezelf stelt? Waarom vind je het belangrijk om op deze manier voor patiënten te zorgen?

Aandachtspunten om door te vragen:

Voel je je verplicht om voor alle patiënten op deze manier te zorgen?

Lukt dat ook? Waarom wel? Waarom niet?

Voelde je je verantwoordelijk voor deze patiënt?

Heb je dat bij alle patiënten? 
Voel je je bij sommige patiënten meer betrokken dan bij andere?

Zou je me ook een voorbeeld kunnen geven van zorg voor een patiënt waarover je niet tevreden was? Een situatie waarvan je nu achteraf denkt dat de zorg er eigenlijk heel anders uit had moeten zien?

Waar ben je volgens jezelf in de zorg voor deze patiënt tekort geschoten?

\section{Moeilijke situaties}

Ben je wel eens in een situatie geweest waarin je in eerste instantie niet wist wat het beste was om te doen?

Komen dat soort situaties vaak voor?

Hoe heb je geprobeerd een oplossing voor dit probleem te vinden?

Aandachtspunten om door te vragen:

Hoe heb je dat probleem aangepakt?

Ben je daar tevreden over? Waarom wel? Waarom niet?

Zou je dat nu anders doen? Hoe dan?

Wie heb je bij de oplossing van dit probleem betrokken?

Waar en met wie heb je het probleem besproken?

Hoe voelde je je in deze situatie?

Kon je er met anderen over praten? Waarom wel? Waarom niet?

Heb je wel eens het gevoel gehad dat je tussen twee vuren in zit? Dat je het gevoel had dat er aan alle kanten aan je werd getrokken?

Aandachtspunten om door te vragen:

Wie waren erbij betrokken?

Hoe heb je geprobeerd uit deze situatie te komen?

Ben je daar tevreden over? Waarom wel? Waarom niet?

Zou je het nu anders doen? Hoe dan?

Waar heb je het probleem besproken?

Met wie heb je het probleem besproken?

Hoe voelde je je in deze situatie?

Kon je er met anderen over praten?

Zou je me een voorbeeld kunnen vertellen van een situatie waarin jie van mening verschilde met de patiënt over wat er moest gebeuren?

Aandachtspunten om door te vragen:

Hoe heb je geprobeerd een uitweg uit dit meningsverschil te vinden?

Ben je daar tevreden over?

Zou je het nu anders doen?

Hoe voelde je je in deze situatie?

Heb je het probleem met anderen besproken?

Hoe zie je de verdeling van verantwoordelijkheden tussen jou en dẽ patiënt?

Wie heeft het laatste woord? Waarom? 


\section{Ethiek}

Zou je me een ethische dilemma kunnen noemen dat je bent tegengekomen in je werk?

Wat is hier volgens jou typisch ethisch aan?

\section{Omgeving verpleegkundige}

Voel je je wel eens geremd om te kunnen zorgen door invloed vanuit de omgeving?

Aandachtspunten om door te vragen:

Door collega verpleegkundigen?

Door andere zorguerleners?

Door leiding van de afdeling?

Door tijdsdruk?

Door de organisatie?

Heb je het idee dat je werk als verpleegkundige wordt gewaardeerd?

Aandachtspunten om door te vragen:

Door patiënten?

Door de leiding van de afdeling?

Door andere zorgverleners?

Door de organisatie waarin je werkt?

Door de samenleving? Mensen uit je omgeving?

\section{Afsluiting}

Heb je alles kunnen vertellen wat je belangrijk vindt in de zorg voor patiënten of zijn er nog dingen die niet aan de orde zijn gekomen? Is er nog iets dat je wil toevoegen? 


\section{Bijlage C: DRAaGLIJKER MAKEN VAN HET BESTAAN}

\section{Fysieke pijn en lijden}

Patiënten kunnen zich zwak of beroerd en ellendig voelen door de behandelingen en onderzoeken die ze krijgen. In dergelijke omstandigheden proberen ver-

pleegkundigen verlichting in de situatie te brengen door bijvoorbeeld:

Begrip te tonen

Positicue feedback te geven

Zorg over te nemen

Aandacht te besteden aan 'kleine dingen'

Wanneer patiënten ernstig pijn lijden als gevolg van ziekte en behandeling, dan proberen verpleegkundigen deze situatie te verlichten door:

Het bieden van comfort

Organiseren van pijnmedicatie

Verpleegkundigen verrichten soms zelf een pijnlijke ingreep aan het lichaam van een patiënt. Wanneer ze dat doen proberen ze de situatie voor patiënten draaglijk te maken door:

Aandacht te besteden aan pijnervaringen van patiënten

Te laten zien dat ze begrijpen dat de ingreep pijnlijk is voor patiënten

Flexibel om te gaan met de regels van een protocol

Tegen opdrachten van artsen in te gaan

Wanneer anderen ingrepen aan het lichaam van patiënten uitvoeren en patiënten daar last van hebben dan:

Staan verpleegkundigen patiënten bij

Of nemen patienten in bescherming door hen een ingreep te besparen

\section{Overrompeld door de behandeling}

Wanneer patiënten zich overrompeld voelen door de behandeling en er behoefte aan hebben zeggenschap te behouden dan:

Informeren verpleegkundigen patienten

Wijzen ze patiënten op sitwaties waarin ze hun stem kunnen laten horen

Creëren ze ruimte voor patienten om hun stem te laten horen

Wanneer patiënten daar behoefte aan hebben dan nemen verpleegkundigen ook zeggenschap over door:

Patiēnten te ontzien

Gesprekken uit te stellen

Soms hebben patiënten vooral behoefte aan betrokkenheid bij hun eigen situatie, dat bevorderen verpleegkundigen bijvoorbeeld door:

Patiënten inzicht te geven in hun situati.

Hen te laten meedoen, mek kijken en vergelijken 
Gedurende het hele proces van zorgverlening proberen verpleegkundigen een compagnon te zijn:

Iemand die meedenkt en meevecht met patiënten

Door vertrouwen te creëren

Door deskundigheid van artsen en verpleegkundigen te benadrukken

Door te laten zien dat deze het goed met hen voor hebben

\section{Een ander leven}

Wanneer patiënten zijn opgenomen in het ziekenhuis en behandeld worden voor een levensbedreigende ziekte, zijn ze gedwongen een ander leven te leiden dan ze gewend waren. Op verschillende manieren proberen verpleegkundigen een dergelijke situatie voor patiënten meer eigen te maken. Ze proberen daartoe de leeforngeving meer vertrouwd te maken door:

Leefruimte anders aan te kleden

Patienten inzicht te geven in het afdelinggebeurend zodat ze weten wat ze kunnen verwachten

Verpleegkundigen besteden ook aandacht aan de tijdsbesteding van patiënten, bijvoorbeeld door:

Zelf als tijdverdrijuer op te treden

Mee te denken of adviezen te geven over het invullen van de tijd

Wanneer de manier waarop patiënten met hun naasten omgaan onder druk staat door de opname, dan proberen verpleegkundigen deze relatie te normaliseren door:

Aandacht te hebben voor zen prive-ruimte

Advies te geven over hoe ze weer even 'echt' samen kunnen zijn

Informatie te geven over ziekte en behandeling

Wanneer patiënten het gevoel hebben dat hun identiteit verloren dreigt te gaan dan: Laten verpleegkundigen aan patiënten zien dat zij de mens achter de zieke zien

Attenderen ze collega's en andere zorgverleners op hun houding ten opzichte van de patiënt

\section{Verloren zeggenschap over de eigen situatie}

Wanneer patiënten het gevoel hebben dat ze de zeggenschap over hun eigen situatie dreigen te verliezen door de opname in het ziekenhuis dan proberen verpleegkundigen dat te bevorderen door:

Informatie over het reilen en zeilen van de afdeling te geven, zodat patienten tijd naar eigen inzicht kunnen doorbrengen

Patienten op de hoogte te brengen van faciliteiten van de afdeling en instelling, zodat ze daarvan gebruik kunnen maken 


\section{Emotionele pijn en lijden}

Wanneer patiënten emotioneel lijden omdat ze geconfronteerd worden met de eindigheid van het bestaan, dan geven verpleegkundigen patiënten de gelegenheid hun verhaal te vertellen door bijvoorbeeld:

Patienten te stimuleren om te praten

Te laten zien dat ze het verhaal horen en begrijpen

Als persoon betrokken te raken

Wanneer patiënten emotioneel lijden, stimuleren verpleegkundigen hen tot reflectie door:

Positieve feedback te geven

Hen te confronteren met de manier waarop ze met het ziek zijn omgaan

Verpleegkundigen bieden patiënten ook troost, wanneer deze emotioneel lijden door:

Hen hoop te geven

Patiënten af te leiden

Niet te praten

Patienten informatie te geven over ziekte en behandeling

Gedurende het hele proces van zorgverlening proberen verpleegkundigen een compagnon te zijn:

Ze tonen zich daarom betrokken bij patiënten

\section{Samen 'ziek'}

Patiënten kunnen er behoefte aan hebben dat verpleegkundigen ook zorgen voor hun familie. Dat doen verpleegkundigen door familie steun te geven, zowel in de vorm van:

Praktische steun en adviezen

Als ook emotionele steun

Verpleegkundigen ondersteunen ook de relatie tussen de patiënt en diens directe naasten wanneer daar behoefte aan is, bijvoorbeeld door:

De onderlinge communicatie te verbeteren

Wederzijds begrip te creëren 



\section{SAMENVATIING}

In deze studie wordt het denken en handelen van verpleegkundigen van een hematologie oncologie afdeling bestudeerd vanuit moreel perspectief. Wat verstaan verpleegkundigen onder goede zorg? Hoe trachten ze deze te geven? Waarom lukt dat soms niet? Aanleiding tot deze studie is de veronderstelling dat verpleegkundigen gefrustreerd en gestrest kunnen raken of burn-out oplopen, wanneer ze niet die zorg kunnen geven die ze zouden willen geven. Door inzicht te verwerven in de wijzen waarop verpleegkundigen in de dagelijkse zorg, goede zorg proberen te geven en door te verhelderen tegen welke problemen, moeilijkheden of belemmeringen ze daarbij aanlopen, wordt met deze studie geprobeerd een bijdrage te leveren aan het verbeteren van de kwaliteit van werken van verplegenden. Daarnaast kan inzicht in morele ervaringen van verpleegkundigen ertoe leiden dat de kwaliteit van zorg voor patiënten verbetert. De wijze waarop verpleegkundigen omgaan met noden van patiënten, kan verder worden bestudeerd, aangescherpt en uitgewerkt wanneer dit zichtbaar is.

De studie start met een theoretische analyse van verschillende benaderingen in de verpleegkundige ethiek. In Nederlandstalige en Angelsaksische literatuur die vanaf 1980 verschenen is, zijn drie perspectieven te onderscheiden namelijk: principe-ethiek, verpleegkundige deugdethiek en zorgethiek. In hoofdstuk 2 worden deze perspectieven op ethiek beschreven om een theoretisch kader te destilleren voor praktijkonderzoek naar morele ervaringen van verpleegkundigen met dagelijkse zorgverlening. Daarbij staan de volgende. vragen centraal: Welke situaties worden als moreel geduid? Welke handvatten worden aangereikt deze situaties te hanteren? Op basis van deze analyse wordt in hoofdstuk 3 betoogd dat zorgethiek een bruikbaar perspectief is om morele ervaringen van verpleegkundigen inzichtelijk te maken. Op de eerste plaats omdat zorgethici er voor pleiten om betrokkenen zelf aan het woord te laten en te bestuderen hoe zij werkzame en leefbare oplossingen vinden, om inzicht te krijgen in de aard, omvang en reikwijdte van morele kwesties. Op de tweede plaats omdat zorgethiek de bredere context waarin zorg wordt gegeven, wil betrekken bij het inzichtelijk maken van morele kwesties, zoals financiële middelen, wet en regelgeving, personele bezetting, en dergelijke. Inzicht in deze context is van belang, omdat deze mede bepalend is voor de 
gedaante die morele kwesties aannemen en voor de ruimte die zorgverleners in hun zorgend handelen ervaren om hun opvattingen over goede zorg in de praktijk te brengen. Op de derde plaats wordt voor zorgethiek gekozen omdat hierin het zorgproces centraal staat. Zorgethiek stelt voor het morele niet zo zeer te zoeken in de vraag of en hoe ethische principes een rol spelen of te bestuderen welke deugden verpleegkundigen nodig hebben om goede zorg te geven. Zorgethici stellen voor om het zorgproces centraal te stellen om inzicht te krijgen in morele problematiek. In deze studie wordt ervan uitgegaan dat met behulp van deze uitgangspunten van de zorgethiek kwesties in beeld gebracht worden die verpleegkundigen tegenkomen wanneer ze in de dagelijkse zorg proberen goede zorg te geven aan patiënten.

De algemene vraagstelling naar morele ervaringen van verpleegkundigen wordt in hoofdstuk 3 geherformuleerd in zorgethisch perspectief. Dit leidt tot de volgende vraagstellingen voor het empirisch onderzoek.

Aan welke zorghehoeften die sumenhangen met het in stand houden of herstellen van de wereld van patiënten proberen verpleegkundigen tegemoet te komen, zodat zij er zo goed mogelijk in kunnen leven?

Hoe proberen verpleegkundigen tegemoet te komen aan zorgbehoeften die samenhangen met het in stand houden of herstellen van de wereld van patienten, zodat $z i j$ er zo goed mogelijk in kunnen leven?

In welke situaties komen verpleegkundigen moeilijkheden, problemen en belemmeringen tegen, juist omdat ze erop gericht zijn patiënten te ondersteunen bij het in stand houden of herstellen van hun wereld zodat zij er zo goed mogelijk in kunnen leven?

Om deze vragen te onderzoeken is gebruik gemaakt van kwalitatieve onderzoeksmethoden: participerende observatie en semi-gestructureerde diepte interviews. Dit onderzoek is uitgevoerd op een hematologie oncologie afdeling. Reden daarvoor is op de eerste plaats de overdraagbaarheid van de resultaten. Door voor een afdeling te kiezen waar veelvoorkomende verzorgende activiteiten verricht worden, kunnen de bevinden uit dit onderzoek herkenbaar zijn voor verpleegkundigen van andere afdelingen en instellingen. Dat wil niet zeggen dat er op een hematologie oncologie afdeling geen gangbare ethische kwesties voorkomen, zoals vragen om euthanasie, het staken van behandeling, het toedienen van morfine of vragen rondom reanimeerbeleid. Dat is wel het geval. Vooral omdat op deze afdeling patiënten zijn opgenomen voor een levensbedreigende ziekte, waar ze intensieve behandelingen voor krijgen waar ze zich erg ziek door voelen, maar die helaas niet 
altijd tot genezing leiden. Op de tweede plaats is voor een hematologie oncologie afdeling gekozen, omdat verwacht wordt dat op een dergelijke afdeling in het oog springende ethische kwesties spelen. Daardoor kan duidelijk gemaakt worden dat - ook wanneer zich dergelijke kwesties voordoen bestudeerd kan worden wat voor verpleegkundigen goede zorg betekent. Ook in situaties waarin patiënten om euthanasie vragen, morfine toegediend krijgen of waarvoor een reanimeerbeleid is afgesproken, helpen verpleegkundigen hen met eten, drinken of uit bed komen, informeren ze patiënten over ziekte en behandeling of praten met hen over de betekenis die het ziek zijn voor hen heeft en kan daarbij bestudeerd worden wat zij in dergelijke situaties onder goede zorg verstaan, hoe ze deze proberen te geven en tegen welke moeilijkheden, problemen en belemmeringen ze daarbij aanlopen.

In de volgende hoofdstukken wordt verslag gedaan van het empirisch onderzoek. In hoofdstuk 4 komt goede zorg in beeld als een proces dat er op gericht is het bestaan voor patiënten zo draaglijk mogelijk te maken. Goede zorg is verbonden met de activiteiten die verpleegkundigen verrichten in het kader van de dagelijkse zorg. Om aan zorgbehoeften van patiënten tegemoet te komen en de situatie voor hen zo draaglijk mogelijk te maken, verrichten de verpleegkundigen tal van activiteiten. Als het bijvoorbeeld gaat om zorgbehoeften die samenhangen met intensieve behandelingen die patiënten ondergaan, dan bieden de verpleegkundigen onder andere comfort, organiseren ze pijnbestrijding, gaan ze flexibel om met opdrachten van artsen of ondersteunen ze patiënten zeggenschap te houden over de behandeling die ze krijgen. Wanneer het gaat om zorgbehoeften die samenhangen met het opgenomen zijn op een afdeling, proberen verpleegkundigen bijvoorbeeld de omgeving meer vertrouwd te maken, besteden ze aandacht aan de inrichting van de kamer, hebben ze aandacht voor dagbesteding of de verhouding van patiënten ten opzichte van familie. In het kader van zorgbehoeften die samenhangen met het hebben van een levensbedreigende ziekte en emotioneel lijden, dan stimuleren verpleegkundigen patiënten bijvoorbeeld hun verhaal te vertellen, geven ze feedback of confronteren ze patiënten met de manier waarop ze met de ziekte omgaan. De activiteiten die verpleegkundigeñ verrichten om de situatie voor patiënten zo draaglijk mogelijk te maken hebben soms een expliciet moreel karakter, zoals de bereidheid betrokken te raken bij patiënten of een compagnon te zijn. Verpleegkundigen verrichten ook activiteiten die ogenschijnlijk louter praktisch of technisch van aard zijn. Deze zijn echter ook moreel, omdat ze erop gericht zijn de situatie voor patiënten draaglijker te maken. Wanneer verpleegkundigen bijvoorbeeld een wond bij een patiënt verzorgen, hebben ze niet alleen aandacht voor de fysieke conditie van de wond, maar ook voor de pijn en ongemak die daaruit voortvloeien. In deze studie wordt geconcludeerd dat de dagelijkse zorg die verpleegkundigen van 
afdeling Io aan patiënten geven voor een belangrijk deel ook moreel is, omdat in het verzorgend handelen zelf geprobeerd wordt de situatie voor patiënten zo draaglijk mogelijk te maken.

In hoofdstuk 4 wordt tegemoet komen aan zorgbehoeften beschreven alsof altijd duidelijk is wat een patiënt nodig heeft om de situatie als draaglijker te ervaren. Dat is echter niet altijd het geval. In hoofdstuk 5 wordt dat besproken. Daar wordt zichtbaar dat de verpleegkundigen werken in en aan onzekerheid om goede zorg te kunnen geven. Tegemoet komen aan zorgbehoeften van patiënten komt in dat hoofdstuk in beeld als een complex proces, omdat niet altijd duidelijk is wat iemand nodig heeft om het bestaan als draaglijker te ervaren. Daarvoor zijn verschillende oorzaken. Dat is bijvoorbeeld het geval omdat zorgbehoeften om interpretatie vragen. Het is niet altijd duidelijk welke vragen en behoeften een patiënt heeft. Patiënten zeggen iets of vertonen bepaald gedrag waaruit verpleegkundigen zorgbehoeften af moeten leiden. Op de tweede plaats kunnen verpleegkundigen onzekerheid ervaren omdat ze zelf invloed hebben op de vorm die zorgbehoeften aannemen. Ze zijn zich daarvan bewust en vragen zich daarom af of deze invloed wel goed is. Op de derde plaats kan zorg onzeker zijn omdat verpleegkundigen verschillende opvattingen kunnen hebben over hoe goed te doen voor een patiënt. Op de vierde plaats kan de situatie van een patiënt voortdurend veranderen, wat tot onzekerheid kan leiden. Zowel de fysieke, emotionele en sociale situatie kunnen veranderen, als ook de patiënt als persoon. In hoofdstuk 5 wordt belicht dat verpleegkundigen echter niet in een impasse raken, ook al kan zorg onzeker zijn. Dat komt omdat verpleegkundigen gebruik maken van verschillende soorten kennis om zicht te krijgen op vragen en behoeften van patiënten. Zo gebruiken ze bijvoorbeeld abstracte kennis van de patiëntencategorie waarvoor ze zorgen. Deze kennis focust hun blik. Door deze kennis zijn verpleegkundigen alert op bepaalde zorgbehoeften. Bovendien verzamelen verpleegkundigen kennis van de specifieke fysieke, emotionele en sociale situatie van een patiënt en diens persoonlijkheid, om zorgbehoeften te signaleren en hanteren. Verpleegkundigen moeten een patiënt leren kennen om begrip te krijgen voor zijn of haar situatie. Om deze individuele kennis te verzamelen zijn verpleegkundigen er daarom op gericht een relatie met een patiënt aan te gaan. In hoofdstuk 5 wordt het morele denken en handelen van verpleegkundigen verder uitgediept door te laten zien dat ze werken in en aan onzekerheid. Daarbij zijn het belang van abstracte kennis, individuele kennis en de voorwaarden van een relatie zichtbaar geworden.

Tegemoet komen aan zorgbehoeften van patiënten is niet alleen een complex proces omdat zorg onzeker kan zijn. Dat is ook het geval omdat verpleegkundigen daarbij problemen en belemmeringen ervaringen. In het laatste empirische hoofdstuk, hoofdstuk 6, worden situaties besproken waarin 
volgens verpleegkundigen goede zorg voor patiënten onder spanning komt te staan. Op de eerste plaats komen daarbij situaties aan de orde waarin patiënten iets vragen, dat volgens verpleegkundigen de draaglijkheid van de situatie niet ten goede komt. Verpleegkundigen hanteren dergelijke situaties door met patiënten te zoeken naar een invulling van het zorgproces dat door beiden wordt gedragen. Op de tweede plaats komen situaties aan de orde waarbij het handelen van verpleegkundigen erop gericht is ruimte te creëren voor hun opvattingen over wat goed is om te doen in relatie tot artsen. Het behandelbeleid van artsen is van invloed op bewegingsvrijheid van verpleegkundige om goede zorg te geven. Wanneer ze deze bewegingsvrijheid te beperkt vinden, proberen ze deze op allerlei manieren op te rekken. Op de derde plaats wordt in hoofdstuk 6 belicht dat zorg voor individuele patiënten gegeven wordt in omstandigheden waarbij verpleegkundigen ook voor zichzelf moeten zorg. Zorg voor patiënten kan onder druk komen, omdat betrokkenheid bij patiënten verbonden is met het risico dat zorgen te zwaar wordt. Hoewel verpleegkundigen erkennen dat zorg voor zichzelf nodig is, kunnen ze het toch als problematisch ervaren wanneer zorg voor patiënten daardoor onder spanning komt te staan. Op de vierde plaats wordt de zorg die verpleegkundigen geven besproken binnen de context van de afdeling. Daardoor werd zichtbaar dat zorg voor individuele patiënten moet worden afgewogen tegen zorg voor andere patiënten. Hoewel verpleegkundigen zien dat deze situatie vaak het gevolg is van werkdruk, ervaren ze het toch als frustrerend als ze tegen patiënten die bijvoorbeeld angstig en onzeker zijn moeten zeggen dat deze hun behoeften aan zorg moeten opschorten. De context van de afdeling beperkt soms bewegingsvrijheid van verpleegkundigen omdat ze zich afvragen of betrokkenheid bij patiënten past bij de opvattingen van professioneel zorgverlenen die binnen de afdeling en instelling circuleren. En tot slot is in 6 hoofdstuk besproken dat de ruimte voor reflectie op het eigen en andermans handelen en emoties op afdeling ro beperkt is, waardoor zorg voor individuele patiënten onder druk kan komen. Niet alleen omdat er te weinig gesproken wordt over de vraag of de geboden zorg wel goed is, maar ook omdat verpleegkundigen hun emoties moeten kunnen uiten en waardering van de leiding nodig hebben om te kunnen blijven zorgen voor patiënten.

Op basis van de inzichten in morele ervaringen van verpleegkundigen die worden beschreven in de empirische hoofdstukken, wordt in deze studie geconcludeerd dat verpleegkundige ethiek aandacht dient te hebben voor bepaalde onderwerpen. In hoofdstuk 7 worden thema's besproken die verdere aandacht en uitwerking verdienen, wanneer ervaringen van verpleegkundigen op de werkvloer uitgangspunt zijn. Bovendien is daarbij bestudeerd in hoeverre zorgethiek daarvoor aanknopingspunten biedt. Op de eerste plaats is betoogd dat dagelijkse zorg een morele lading heeft. Verpleegkundigen han- 
teren opvattingen van goede zorg die van invloed zijn op de zorg die ze geven. Bovendien hangen zorgen en ethiek met elkaar samen omdat allerlei praktische en technische activiteiten die ogenschijnlijk niets met ethiek van doen hebben, moreel zijn. Vanuit deze bevindingen wordt in dit onderzoek beargumenteerd dat ethici moeten kijken en luisteren naar verpleegkundigen op de werkvloer om zicht te krijgen op de aard en omvang van ethische kwesties. Deze bevinding sluit aan bij het pleidooi van zorgethici om zorg als praktijk op te vatten. Dit praktijk-denken kan in het kader van verpleegkundige ethiek gebruikt worden om morele ervaringen van verpleegkundigen verder uit te werken en aan te scherpen. Op de tweede plaats is het concept 'zorgrationaliteit' uit de zorgethiek bruikbaar om de wijzen waarop verpleegkundigen van afdeling Io zorgbehoeften hanteren verder te bestuderen. Zorgen heeft een eigen rationaliteit waarin doen, kennen, voelen, redeneren en overleggen samenkomen. Om de situatie voor patiënten draaglijker te maken verrichten verpleegkundigen activiteiten waarbij ze gebruik maken van theoretische kennis, praktische kennis en relationele vaardigheden. Bovendien overleggen ze met andere zorgverleners en denken ze samen na over de vraag wat goed is om te doen. De zorgethiek maakt deze zorgrationaliteit tot onderwerp van studie. Ze kan gebruikt worden om het denken en handelen van verpleegkundigen verder te bestuderen. Op de derde plaats is 'betrokkenheid' een belangrijk kenmerk van de zorg die verpleegkundigen aan patiënten geven. Daarom is een breed scala aan betekenissen van betrokkenheid besproken, zowel vanuit morele ervaringen van verpleegkundigen als vanuit de zorgethiek. Het thema 'betrokkenheid' wordt daarbij zichtbaar als: antwoord op kwetsbaarheid, voorwaarde voor vertrouwen, voorwaarde voor kennis, als valkuil en als identiteit. Op de vierde plaats is uiteengezet dat 'in discussie met patiënten' een belangrijk kenmerk van zorg is. Verpleegkundigen zijn regelmatig in gesprek met patiënten over de vraag wat goed is om te doen op een bepaald moment. Hierbij is het handelen van verpleegkundigen er op gericht cen situlitie te creëren die voor beiden leefbaar en werkbaar is. Daarom wordt ruimte gecreëerd voor patiënten om hun gevoelens, ervaringen, meningen en opvattingen over goede zorg naar voren te brengen. Tegelijkertijd brengen verpleegkundigen hun eigen opvattingen over goede zorg naar voren. Verpleegkundigen zoeken naar overeenstemming met patiënten, omdat ze ervan uitgaan dat een gezamenlijk gedragen zorgproces de situatie voor patiënten draaglijker zal maken. Het handelen van verpleegkundigen is er daarom op gericht conflicten te voorkomen en de communicatie open te houden. De zorgethiek is bruikbaar on verpleegkundigen te ondersteunen in hun discussie met patiënten om tot een gezamenlijke invulling van het zorgproces te komen. Termen uit de zorgethiek als 'compasionate interference', 'geprivilegicerde onverantwoordelijkheid', 'relationele autonomie als authenticiteit' 
en 'vertrouwen' zijn bruikbaar om het denken en handelen van verpleegkundigen in het kader van verpleegkundige ethiek verder te bestuderen. Tenslotte is in hoofdstuk 7 het onderwerp 'macht en onmacht' besproken. Het raamwerk van zorg, zoals dat is uitgewerkt door Tronto in een proces van vier fasen, is bruikbaar om kwesties van macht in de verpleging aan de orde te stellen. 'Macht en onmacht' is een relevant onderwerp voor verpleegkundige ethiek, omdat de context waarin wordt gezorgd mede bepaalt hoeveel riimte verpleegkundigen ervaren om goede zorg te geven. Dit geldt bijvoorbeeld voor het behandelbeleid van artsen en voor de institutionele context waarin zorg wordt verleend. Deze moeten daarom betrokken worden bij het inzichtelijk maken van morele kwesties die spelen in de dagelijkse zorgverlening. Met behulp van het raamwerk van Tronto kunnen verdelingen van verantwoordelijkheden in de zorg zichtbaar worden. Dan blijkt bijvoorbeeld dat verpleegkundigen als gevolg van de context van behandelbeleid en het beleid binnen de instelling, soms zorg uitvoeren waarvan zij de inhoud niet zelf bepalen. Dat heeft consequenties voor hun ervaringen met zorgverlenen. Het is van belang kwesties van macht en verantwoordelijkheid zichtbaar te maken. Inzicht in het denken en handelen van verpleegkundigen en in hun opvattingen van goede zorg is hierbij een belangrijke voorwaarde, omdat de ruimte om de inhoud van de zorg te bepalen op subtiele manier verweven is met het dagelijks denken en handelen.

In hoofdstuk 8 wordt tot besluit van dit boek teruggegrepen op de aanleiding van het onderzoek, namelijk de veronderstelling dat verpleegkundigen gefrustreerd en gestresst kunnen raken of een burn-out oplopen, wanneer ze niet díe zorg kunnen geven die ze zouden willen geven én wanneer ze onvoldoende ondersteuning ervaren bij het uitvoeren van die zorg. Hoe kan inzicht in morele ervaringen ertoe bijdragen dat verpleegkundigen zich meer gesteund en gewaardeerd voelen bij de zorg die ze geven? In hoofdstuk 8 wordt beargumenteerd dat inzicht in de opvattingen van goede zorg die verpleegkundigen hanteren, ertoe kan bijdragen dat verpleegkundigen zich meer bewust worden van hun specifieke bijdrage aan zorg voor patiënten binnen de gezondheidszorg. Hierdoor kan hun gevoel van eigenwaarde worden versterkt en zijn ze misschien beter in staat zich sterker te profileren ten opzichte van andere zorgverleners, de instelling of de overheid. Inzicht in opvattingen van goede zorg kunnen er bovendien toe bij dragen dat de kwaliteit van zorg voor patiënten verbetert, omdat waarden die zichtbaar zijn besproken kunnen worden en verder uitgewerkt en aangescherpt. Inzicht in morele ervaringen van verpleegkundigen kan daarnaast een bijdrage leveren aan het overdenken van de vraag wat professioneel zorgverlenen betekent. In het onderzoek wordt zichtbaar dat verpleegkundigen erop gericht zijn de draaglijkheid van de situatie van patiënten te bevorderen. Dit 
inzicht zou een rol kunnen spelen bij het uitwerken van opvattingen over professionaliteit, zodat datgene wat verpleegkundigen belangrijk en waardevol vinden in de zorg hierin verdisconteerd kan worden. Tot slot is in hoofdstuk 8 beargumenteerd dat inzicht in morele ervaringen van verpleegkundigen ertoe kan bijdragen dat hun opvattingen van goede zorg een grotere rol spelen in overwegingen van managers en beleidsmakers bij het organiseren en financieren van de zorg. Verpleegkundigen zouden daartoe meer ruimte moeten krijgen om hun opvattingen van goede zorg met elkaar te bespreken en binnen de instelling te ventileren. Niet alleen omdat het van belang is dat verpleegkundigen zich herkennen in de zorg die geven, maar ook omdat ze ondersteund moeten worden - bijvoorbeeld in de vorm van functioneringsof coachingsgesprekken, supervisie of moreel beraad - bij het uitvoeren van die zorg. 


\section{SUMMARY}

This study analyzes the thoughts and actions of hematology oncology nurses from a moral perspective. The focus is on questions like: What do nurses consider to be good care? How do they try and provide good care? And why are they not always successful? This study sprang from the assumption that nurses can experience frustration and stress or even burn-out if they are not able to give the support they would like to give. By obtaining insight in the ways nurses try to give good care as part of their daily activities, and through clarifying the problems, difficulties, and obstacles they meet, this study contributes to improving nurses' quality of work. Further, insight in moral experiences of nurses might also improve the quality of care given to patients. By articulating these insights, the ways in which nurses deal with patients' needs can also be examined, elaborated, and accentuated further.

The study begins with a theoretical analysis of the various perspectives in nursing ethics. Several schools can be distinguished within nursing ethics. An examination of Dutch and Anglo-American literature from I980 onwards, revealed three different perspectives: principle-ethics, nursing virtue ethics and care ethics. The study of these three perspectives on ethics formed the theoretical basis to conduct the field research on moral experiences of nurses (chapter two). Guiding questions were: What situations are considered to be moral? What instruments are suggested to handle these situations? In chapter three I argue that care ethics is a useful perspective to create insight into moral experiences of nurses. The starting question of this study about nurses' moral experiences is reformulated in terms of the care ethical perspective discussed in chapter two. Key questions for the empirical research are:

What kind of specific needs for care do nurses try to meet to maintain, continue, and repair the patients world, so they can live in it as well as possible?

How do nurses try to meet those patients' needs to maintain, continue, and repair the patients world, so they can live in it as well as possible?

What kind of difficulties and obstacles do nurses experience, by trying to make their patients' lives as well as possible? 
These questions are addressed by using the qualitative methodology of participatory observation and semi-structured in-depth interviewing. The research has been carried out on a hernatology oncology department of an Academic Hospital, mainly because of the transferability of the results. The occurrence of a lot of common care can make the results of this study recognizable for nurses of other departments and institutions. Furthermore, although a lot of common care activities are performed at this department, the moral dimension of care is enhanced here, because the admitted patients are being treated for life threatening diseases.

Chapters 4-6 give a description of the empirical research. Chapter four shows how moral issues are connected with those activities nurses perform for the daily care of patients. To meet patients' needs for care and to make their situation as bearable as possible, nurses perform many different activities. For instance, for needs that are related to the intensive treatment patients receive, nurses offer comfort, take care of pain control, deal with doctors' orders in a flexible manner, and stimulate patients in having their own say about their treatment. For needs that are related to being admitted to a department, nurses try to make the surroundings more familiar, they pay attention to the way a room looks, they attend to the way in which patients spend their time, and to the relationship with their family. For those needs that are related to having a life-threatening disease and to emotional suffering, nurses motivate patients to tell their story, they give feedback or confront patients with the way they handle their disease. Activities performed by nurses to alleviate the patient's situation are sometimes explicitly moral, their willingness to become involved with a patient, for instance, or to act as a companion. On the other hand, nurses also perform activities that appear as purely practical or technical. In this study, it is shown, however, that such activities can also be considered moral activities, since they are aimed at making life more bearable for patients. When tending a patient's wound, for example, the nurse is not only concerned about the physical aspects of the wound itself, but also attends to the pain and inconvenience caused by it. Thus, one of the conclusions of this study is that the daily care that nurses give to patients of the hematology oncology department is for an important part moral. It can be considered moral because nurses try to make the situation for the patient as bearable as possible in the act itself of taking care of the patient.

Chapter four describes the ways in which nurses try to meet patients' needs as it is apparent what the patient requires for a bearable life. This is not always the case as is discussed in chapter five. Meeting patients' needs for care is a complex process, because it is precisely not always clear what it takes to make one's life bearable. Several reasons are given. First, needs for care require interpretation. It is not always clear what kinds of questions or needs a 
particular patient has. Patients say things and do things, from which nurses have to infer specific needs. And secondly, nurses may experience uncertainty, because they influence the way care-needs develop. Nurses are very much aware of this process and they worry about whether their influence is appropriate. Thirdly, nurses may differ in their opinions about how to act and what can be considered good care for a particular patient. And finally, the patient's situation may change constantly - physically, emotionally, and socially - which could lead to uncertainty. Also, the patient him/herself may change. In chapter five it is shown that even if care taking can be uncertain, this does not mean that the nurses reach an impasse. The reason is that nurses use different kinds of knowledge to gain insight into patients' needs and questions. They use abstract knowledge of the patient-category they take care of. This knowledge focuses them; it alerts them to certain needs for care. Nurses also collect knowledge about the specific physical, emotional and social situation of the patient and about his personality to spot and handle individual needs. Nurses need to get to know the patient to understand his or her specific situation. To obtain such individual insight, nurses are focused on building a relationship with a patient. Chapter five extends the analysis of nurses' moral thoughts and actions by showing that nurses work is characterized by uncertainty. However nurses do accept this passively, but they use abstract knowledge, individual knowledge and building a relationship with patients in order to manage insecurity.

Meeting patients needs for care is a complex process not only because of the insecurity of care itself, but also because nurses experience difficulties and obstacles when caring for patients. In the last empirical chapter, chapter six, situations are discussed in which, according to nurses, good care is threatened. First, situations are presented in which patients asked for something that, would not alleviate their situation, according to the nurses. Nurses handle situations like these by trying to create a care-process, together with the patient, that is acceptable to both. Secondly, situations are presented in which nurses' acts were focused on creating space for their opinions about what should be done, in comparison to the doctors' opinions. Doctors' policies for treatment influence the nurse's freedom of movement to provide good care. When nurses consider their freedom of movement to be too limited, they try in various way to expand it. In the third place, chapter six shows how the care for individual patients is given in situations in which nurses have to take care of themselves as well. Involvement with patients may turn care-taking into a responsibility that risks becoming too difficult. This may threaten care for patients. Although nurses recognize the fact that caring for themselves is necessary, they may find this problematic when it threatens the care for their patients. Furthermore, the care nurses provide is related to the context of the 
department. In doing so it becomes visible that care for individual patients must be considered against care for other patients. Although nurses realize that this is caused by their workload, they experience frustration when they have to tell patients who are scared and insecure that their needs for care have. to wait. 'The context of the department may also limit nurses' freedom of movement, because they wonder whether their involvement with patients is in line with the standards of professional care circulating within the department and institution. Chapter six, finally, shows that in the department, the room for reflection on one's own and on others' actions and emotions is limited, resulting in strain on the care for individual patients. This happens not only because the question is not discussed whether the care given was good, but also because nurses should be able to express their feelings and they should receive marks of appreciation from their management in order to maintain the care for their patients.

Based on the insights into nurses' moral experiences as described in the three empirical chapters, it was concluded in this study that nursing ethics needs to pay attention to certain issues. For those cases in which nurses' experiences "on the shop floor" are taken as the starting-point of the investigation, chapter seven indicates issues for further investigation and articulation. These issues are: the moral quality of care taking activities, the rationality of. care, involvement, discussions with patients, and issues of power. At the same this chapter discusses whether and how the perspective of care ethics deals with these issues. The other two perspectives on ethics (principle-ethics and virtue ethics) are used to form a contrast, and to develop those issues that care-ethics does not cover extensively.

Chapter eight recalls the initial inspiration for this study: The assumption was that nurses may become frustrated and stressed, or even become burntout, first, when they are unable to provide the care they would like to, and second, when they feel that they receive insufficient support whilst providing care. In what way might insight in nurses' moral experiences improve their feeling of support and appreciation for the care they provide? In chapter eight it is argued that insight in the values that nurses utilize when giving care can contribute to nurses' awareness of their specific contribution to patients' care in the health care system. This may increase their self-esteem and therefore may encourage them to emphasize their distinctive characteristics to other caretakers, the institution or the government. Insight in nurses' values of good care may also contribute to an increase of the quality of care for patients: values that are visible can be discussed, developed and articulated further. Furthermore, insight in nurses' moral experiences can contribute to considerations about the meaning of professional care. This research shows that nurses are focused on making their patients' situation more bearable. This 
insight may play a role when developing notions about nurses professionalism. Nurses' ideas about what is important and valuable about care might then become a part of the notion of professionalism. Insight into nurses' moral experiences, finally, may help to put nurses' notions of good care on the agenda of management and policy makers when they consider organizational and financial issues regarding care. More opportunities should be created for nurses to discuss their opinions about good care and to ventilate these opinions within the institution. This is important not only because nurses should be able to recognize themselves in the care they give, but also because nurses need to be supported in their performance of good care. Evaluation and coaching sessions, supervision and moral deliberation meetings may support nurses to provide the care they know to be good. 



\section{Curriculum Vitae}

Marie-Josée Smits is geboren op 4 november 1964 te Heerlen. Na het behalen van haar HAvo diploma aan het Sancta Maria College te Kerkrade West, studeerde zij vanaf I 982 Verpleegkunde aan de HBO-V van de Gezondheidsacademie te Sittard. Na het behalen van haar Colloquium Doctom startte zij in 1986 met de studie Gezondheidswetenschappen aan de Universiteit Maastricht. In I99 I behaalde zij haar doctoraaldiploma in de afstudeerrichtingen Verplegingswetenschap en Theorie van de Gezondheidswetenschappen. In I 992 werd zij als toegevoegd onderzoeker (in het kader van een Europees onderzoek naar gezondheidszorgopleidingen) aangesteld bij de sectie Gezondheidsethiek \& Wijsbegeerte van de vakgroep Zorgwetenschappen van dezelfde universiteit. Vanaf 1993 tot 2002 is zij bij deze vakgroep werkzaam geweest als AIO en later als Onderzoeker (in het kader van een Onderzoeksproject Palliatieve Zorg) en Docent (met name Ethiek en Kwalitatief Onderzoek). Sinds januari 2003 is zij werkzaam als Beleidsmedewerker in de ouderenzorg, namelijk bij de Regio Heerlen Zuid van VZR (Centra voor Verpleging. Zorg en Reactivering). 
Door de groei van de bevolking, de voortschrijdende medische ontwikkelingen en de vergrijzing, is de vraag naar zorg de afgelopen jaren sterk toggenomen. Maar het aantal verpleegkundigen heeft hiermee geen gelijke tred gehouden. Integendeel zelfs, het percentage uitvallers is groter dan bii de gewone beroepsbevolking. Een belangrijke reden hiervoor is stress en burn-out. Verschil van mening over wat goede zorg inhoudt, onvoldoende ruimte om die opvattingen te kunnen ventileren, te weinig speelruimte in de uitoefening van de functie liggen hieraan ten grondslag. Over deze morele problematiek gaat deze studie.

Marie-Josée Smits heeft het onderzoek uitgevoerd op een hematologie oncologie-afdeling, waar patiēnten opgenomen zijn die voor een levensbedreigende ziekte worden behandeld. Voor deze patiēnten proberan verpleegkundigen het bestaan zo draaglijk mogelijk te maken. Soms ervaren verpleegkundigen onvoldoende ruimte om deze goede zorg te geven, bijvoorbeeld omdat de werkdruk hoog is, door behandelbeleid van artsen of door onvoldoende waardering en ondersteuning vanuit de arganisatie. Kennis en vaardigheden die varpleegkundigen nodig hebben om hat bestaan voor patiēnten 20 draaglijk te mogelijk maken én om binnen allerlei machtsverhoudingen te zoeken naar ruimte om goede zorg te geven, laat zich symboliseren door het Hand-Hoofd-Hart concept, waarin doen, denken, voelen, redeneren en overleggen samenkomen

Deze studie is van belang voor eenieder dis in de zorg werkzaam is, verpleegkundigen en artsen.

Marie-Josee Smils studiente na haar HBO-Vapleiding Gezancheids welenschappan aan de Universiteit Maastricht, waar zij ook tien jaar werkte als docent ten onderzoeker. Thats is zij Belesidsmedeweiker bị de Rogio Hearlen Zuid van Stichting VZR (centra voor verpleging, zarg en reactiveringl

aksant

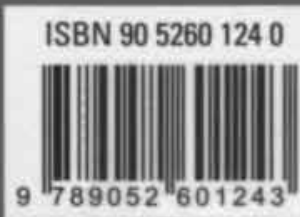

